UNIVERSIDADE DE BRASÍLIA

INSTITUTO DE CIÊNCIAS SOCIAIS

DEPARTAMENTO DE SOCIOLOGIA

\title{
O PROCESSO DE FORMAÇÃO DA LEI DE COTAS E O RACISMO INSTITUCIONAL NO BRASIL
}

Vanessa Patrícia Machado Silva 
UNIVERSIDADE DE BRASÍLIA

INSTITUTO DE CIÊNCIAS SOCIAIS

DEPARTAMENTO DE SOCIOLOGIA

\title{
O PROCESSO DE FORMAÇÃO DA LEI DE COTAS E O RACISMO INSTITUCIONAL NO BRASIL
}

\author{
Vanessa Patrícia Machado Silva
}

Dissertação apresentada ao Departamento de Sociologia da Universidade de Brasília, como parte dos requisitos para a obtenção do título de Mestre. 
UNIVERSIDADE DE BRASÍLIA

INSTITUTO DE CIÊNCIAS SOCIAIS

DEPARTAMENTO DE SOCIOLOGIA

DISSERTAÇÃO DE MESTRADO

\section{O PROCESSO DE FORMAÇÃO DA LEI DE COTAS E O RACISMO INSTITUCIONAL NO BRASIL}

Autora: Vanessa Patrícia Machado Silva

Orientador: Joaze Bernardino Costa, professor adjunto da Universidade de Brasília

\section{Banca:}

Dra. Nilma Lino Gomes, professora da Universidade Federal de Minas Gerais (examinadora)

Dr. Emerson Ferreira Rocha, professor da Universidade de Brasília (examinador)

Dr. Mário Theodoro, consultor legislativo do Senado Federal e professor da Universidade de Brasília (examinador) 
Dedico este trabalho, com todo o amor, às minhas avós.

Vovó Olga Basílio e Vovó Carminda Patrício me ensinam sempre que nossos passos vêm de longe. Eu não chegaria até aqui se não fosse a luta incansável de vocês. 


\section{AGRADECIMENTOS}

Agradeço a Deus por haver me sustentado nessa árdua caminhada de intenso aprendizado e crescimento pessoal.

Agradeço aos meus pais, Marcelo Machado e Jaine Basílio, pelo amor incondicional, cuidado contínuo e constante suporte. Pai e Mãe, vocês são meu porto seguro. Muito obrigada por tudo.

Agradeço ao meu irmão, Marcelo Machado Júnior, pela companhia, troca de ideias, paciência e apoio. Celo, você tem sido meu melhor amigo nessa trajetória e eu não conseguiria sem você ao meu lado.

Agradeço ao meu orientador, Joaze Bernardino, pelo constante incentivo, pelas muitas reuniões de orientação em que eu sempre aprendia algo novo, pelo respeito com que sempre tratou a mim e as minhas ideias, pela paciência com a minha disponibilidade restrita de tempo, por ser uma referência (não só para mim, mas para vários estudantes negros da Universidade de Brasília) de postura político-acadêmica. A nossa parceria para esta produção foi um encontro muito feliz, professor. Obrigada!

Agradeço a todos os meus familiares, que sempre me recebem com palavras carinhosas de incentivo e admiração. Contar com o suporte de cada um de vocês me fortalece diariamente. Mesmo correndo o risco de injustamente me esquecer de alguém, preciso destacar: Tia Denise, obrigada por sempre ouvir minhas ideias e ler meus textos com cuidado e atenção. Tia Maria Regina, obrigada por sempre estar disponível para cuidar de mim. Vitória, obrigada por ser minha companheira de luta e minha melhor confidente. Sofia, poder experimentar as dores e delícias da pós-graduação em Universidades públicas ao seu lado me fortaleceu, muito obrigada. Vovó Olga e Vovó Carminda, muito obrigada por abrirem os caminhos para que eu pudesse chegar até aqui. Eu amo muito todos vocês.

Agradeço ao grupo de estudos de Mulheres Negras da UnB, ao núcleo de estudos em cultura jurídica e Atlântico Negro (Maré) da UnB e ao coletivo de estudantes negros Pretitude Sociológica por todas as trocas de ideias e afetos, por todas as discussões e reflexões que me fizeram crescer e amadurecer enquanto pessoa e pesquisadora.

Agradeço, com todo carinho e admiração, minhas novas e queridas amigas Taís Machado, Bruna Pereira, Renata Monteiro, Ellen Cintra, Raissa Roussenq e Marjorie Chaves. A experiência da pós-graduação ganhou um novo significado quando conheci vocês, obrigada pelo apoio, pelas palavras de incentivo e força, pelos encontros descontraídos, pelo compartilhamento de material e referências, por todo afeto e carinho que sempre senti de vocês. A expressão "Uma sobe e puxa a outra" se materializa no meu dia-a-dia com vocês. Muitíssimo obrigada! 
Agradeço às minhas amigas Tathyana Sales, Caroline Dias, Célia Machado, Letícia Medeiros, Camilla Oliveira e Jayane Maia pelo apoio, companheirismo e carinho. Sempre me senti amparada ao compartilhar as alegrias e as dificuldades desse caminho com vocês, que atentamente me ouvem e me aconselham. Muito obrigada.

Agradeço aos amigos Marcos Queiroz, Leonardo Rauta, Marcelo Rocha, Taynara Candida, Manuela Leda, Matheus da Costa, Alfonso Vargas, Fernando Franciosi, Juliana Brussi, Rayane Noronha e Fran pelo encontro, pelas trocas e pela companhia.

Agradeço a Carlos Nico e à Rosangela Medeiros Ferreira pelo apoio indispensável, pelo cuidado, profissionalismo e carinho que sempre me ofereceram.

Agradeço aos meus colegas de trabalho, Jaqueline Silva, Priscila Martins, Lília Milhomen, Ana Zorzenon, Rafael Nogueira, Andrea David e Ana Flávia Lopes pela paciência e respeito às minhas ideias. Trabalhar nessa equipe me possibilitou ampliar reflexões e críticas sobre a realidade. Também, agradeço às amigas Camilla Abreu e Andressa Margoto por todo apoio e pelas muitas conversas em que compartilhei meus aprendizados do mestrado.

Agradeço ao Departamento de Sociologia da Universidade de Brasília, a todos os seus professores, aos servidores e aos trabalhadores terceirizados que me oportunizaram viver essa experiência de crescimento e aprendizado ímpar.

Agradeço ao CNPQ pelo apoio. 


\section{RESUMO}

Este trabalho se propõe a investigar como se deu o processo de formação da Lei de Cotas (Lei $\mathrm{n}^{\mathrm{o}}$ 12.711/2012). A partir de referências teórico-analíticas do modelo do ciclo das políticas públicas e, principalmente, do conceito de racismo institucional, procura-se analisar como aconteceu o tramite legislativo das propostas que deram origem à Lei. Busca-se identificar os acordos e as divergências, os conflitos e as parcerias, os embates e as alianças que foram sendo construídas para que fosse possível a existência dessa Lei. Interessa ao trabalho observar e refletir sobre como a questão racial - até então central nas discussões sobre ações afirmativas no Brasil - foi incorporada marginalmente na norma. Para tanto, é realizada uma revisão bibliográfica sobre aspectos basilares para a compreensão da formação da Lei de cotas. Em seguida, há um capítulo dedicado à análise documental da tramitação legislativa dessa matéria. Também, realiza-se a análise de notas taquigráficas de sete audiências públicas sobre cotas realizadas no Congresso Nacional. E, por fim, discute-se as principais características da formação dessa Lei a partir das lentes do conceito de racismo institucional. Argumenta-se que a Lei de Cotas é um complexo arranjo institucional que busca conciliar interesses múltiplos e conflitantes, sendo que a incorporação marginal da questão racial na legislação foi amparada pelo já conhecido e confrontado mito da democracia racial. Algumas práticas e alguns discursos analisados são compreendidos por esse trabalho como elementos que indicam o funcionamento do racismo institucional na formação de uma política pública no Brasil. Brevemente, o trabalho apresenta o pensamento feminista negro de Patrícia Hill Collins como uma proposta interessante para pensar as relações de poder e os mecanismos para contrapor-se às práticas de dominação e subordinação. Este estudo visa, portanto, agregar-se e colaborar com as reflexões sobre as políticas públicas com critério racial no país.

Palavras-chave: Lei de Cotas, Lei 12.711/2012, racismo institucional, formação de política pública. 


\begin{abstract}
The present study aims to investigate the process of the creation of the Quota Law (Law n 12.711/2012). Based on analytical-theoretical references from the public policies cycle model and, primarily, on the concept of institutional racism, it aims to analyze how the legislative procedures of the proposals which created the Law took place. It seeks to identify the agreements and the divergences, the conflicts and the partnerships, the struggles and the alliances which were built to make the Law become possible. It's relevant for this study to observe and to reflect on how the racial issue - hitherto central in the discussions about affirmative actions in Brazil - was marginally incorporated in the regulation. To achieve this goal, a literature review about the basic aspects to the understanding of the constitution of the Quota Law was conducted. This is followed by a chapter dedicated to analyze the documents involved in the legislative procedures of this matter. Besides that, the shorthand notes of seven public hearings about the quotas in the National Congress are examined. Finally, the most remarkable characteristics of the creation process of the Law are discussed through the institutional racism concept lens. It is argued that the Quota Law is a complex institutional arrangement which seeks to balance multiple and contradictory interests, considering that the marginal incorporation of the racial question into the legislation was sustained by the well known and confronted myth of racial democracy. Some practices and also some ideas analyzed are understood by the present study as elements that indicate how institutional racism operates in the creation of public policies in Brazil. Briefly, the present study presents the black feminist thought of Patricia Hill Collins as an interesting tool to understand power relations and in mechanisms to oppose domination and subordination practices. Thus, the present study aims to add to and also collaborate with the reflections about the public policies with racial criterion in the country.
\end{abstract}

Keywords: Quota Law, Law 12.711/2012, institutional racism, public policies creation. 


\section{LISTA DE TABELAS, QUADROS E FIGURAS}

Figura 1 - Distração das etapas do ciclo das políticas públicas.

Figura 2 - Imagem de gráfico sobre a produção normativa federal (IPEA).

Quadro 3 - Quadro com as legislações relacionadas à raça no âmbito federal.

Figura 4 - Esquema da distribuição das vagas da Lei de Cotas.

Quadro 5 - Quadro explicativo sobre o poder conclusivo das Comissões.

Quadro 6 - Casos de desarquivamento da proposição.

Figura 7 - Imagem do PL 73/1999.

Quadro 8 - Designações do PL 73/1999.

Quadro 9 - Informações gerais sobre as Audiências Públicas sobre cotas realizadas no Congresso Nacional.

Quadro 10 - Movimentos sociais presentes na Audiência Pública de 15/06/2004.

Figura 11 - Rede sobre a fala de reconhecimento do racismo nas Audiências Públicas da Câmara dos Deputados.

Figura 12 - Rede sobre a fala de reconhecimento do racismo nas Audiências Públicas do Senado Federal. 


\section{LISTA DE SIGLAS}

AC - Acre

ADCT - Ato das Disposições Constitucionais Transitórias

ADPF - Arguição de Descumprimento de Preceito Federal

AL - Alagoas

ANDIFES - Associação Nacional dos Dirigentes das Instituições Federais de Ensino

Superior

AP - Amapá

BA - Bahia

CCJ - Comissão de Constituição e Justiça

CCN - Centro de Convivência Negra

CDDN - Conselho de Defesa dos Direitos do Negro

CDH - Comissão de Direitos Humanos e Legislação Participativa

CE - Comissão de Educação, Cultura e Esporte

CEC - Comissão de Educação, Cultura e Desporto

CEERT - Centro de Estudos das Relações de Trabalho e Desigualdades

COMVEST - Comissão Permanente para os Vestibulares

CR - Coeficiente de Rendimento

DEM - Democratas

Dep. - Deputado

DF - Distrito Federal

ENEM - Exame Nacional do Ensino Médio

ES - Espírito Santo

EUA - Estados Unidos da América

FIES - Fundo de Financiamento Estudantil

FHC - Fernando Henrique Cardoso

FLACSO - Faculdade Latino-Americana de Ciências Sociais

FORAFRO - Fórum Afro da Amazônia

FUNAI - Fundação Nacional do Índio

GEA - Grupo Estratégico de Análise da Educação Superior no Brasil

GEMAA - Grupo de Estudos Multidisciplinares da Ação Afirmativa

GO - Goiás

GTDEO - Grupo de Trabalho para a Eliminação da Discriminação no Emprego e na

Ocupação

GTI - Grupo de Trabalho Interministerial

IBGE - Instituto Brasileiro de Geografia e Estatística

IES - Instituto de Ensino Superior

INEP - Instituto de Estudos e Pesquisas Educacionais

IPEA - Instituto de Pesquisa Econômica Aplicada

LAESER - Laboratório de Análises Econômicas, Históricas, Sociais e Estatísticas de

Relações Raciais

LDB - Lei de Diretrizes e Bases de Educação Nacional

MA - Maranhão

MEC - Ministério da Educação

MG - Minas Gerais

MNM - Movimento Nação Mestiça

MNS - Movimento Negro Socialista

MNU - Movimento Negro Unificado

MSU - Movimento dos Sem Universidade 
MT - Mato Grosso

NEAB - Núcleo de Estudos Afro-Brasileiros

ONG - Organização Não Governamental

ONU - Organização das Nações Unidas

PA - Pará

PB - Paraíba

PCdoB - Partido Comunista do Brasi

PE - Pernambuco

PFL - Partido da Frente Liberal

PL - Projeto de Lei

PLC - Projeto de Lei da Câmara

PLS - Projeto de Lei do Senado

PMDB - Partido do Movimento Democrático Brasileiro

PNAA - Programa Nacional de Ação Afirmativa

PNE - Plano Nacional de Educação

PNPIR - Política Nacional de Promoção da Igualdade Racial

PP - Partido Progressista

PPS - Partido Popular Socialista

PR - Paraná

PRONATEC - Programa Nacional de Acesso ao Ensino Técnico e Emprego

PROUNI - Programa Universidade para Todos

PSB - Partido Socialista Brasileiro

PSDB - Partido da Social Democracia Brasileira

PT - Partido dos Trabalhadores

PUC - Pontifícia Universidade Católica

REUNI - Reestruturação e Expansão das Universidades Federais

RICD - Regimento Interno da Câmara dos Deputados

RJ - Rio de Janeiro

RS - Rio Grande do Sul

SC - Santa Catarina

SE - Sergipe

SECAD - Secretaria de Educação Continuada, Alfabetização e Diversidade

SEPPIR - Secretaria Especial de Políticas de Promoção de Igualdade Racial

SP - São Paulo

SPM - Secretaria de Políticas para as Mulheres

Sr. - Senhor

STF - Supremo Tribunal Federal

TEN - Teatro Experimental Negro

UBES - União Brasileira dos Estudantes Secundaristas

UEMS - Universidade Estadual do Mato Grosso do Sul

UERJ - Universidade Estadual do Rio de Janeiro

UFBA - Universidade Federal da Bahia

UFRJ - Universidade Federal do Rio de Janeiro

UnB - Universidade de Brasília

UNE - União Nacional dos Estudantes

UNEB - União Educacional de Brasília

UNESCO - United Nations Educational, Scientific and Cultural Organization. Organização das Nações Unidas para a Educação, a Ciência e a Cultura.

UNICAMP - Universidade de Campinas.

USP - Universidade de São Paulo 


\section{SUMÁRIO}

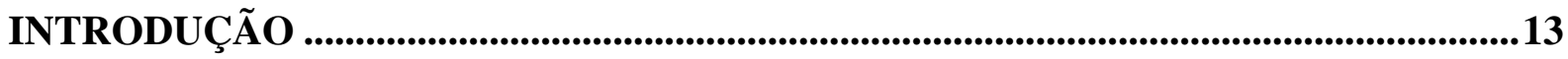

OBJETO, OBJETIVOS, HIPÓTESE E JUSTIFICATIVA DA PESQUISA .........................15

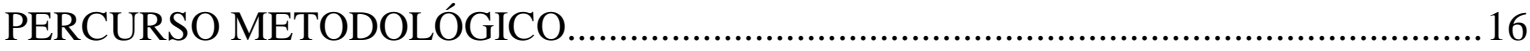

ESTRUTURA DA DISSERTAÇÃO...............................................................................

CAPÍTULO 1 ASPECTOS BASILARES PARA A COMPREENSÃO DA LEI DE COTAS .....................................................................................................................................19

1.1 SOBRE RAÇA, RACISMO E RACISMO INSTITUCIONAL ......................................19

1.2 ESTUDOS SOBRE RELAÇÕES RACIAIS E RACISMO NA CIÊNCIA SOCIAL DO

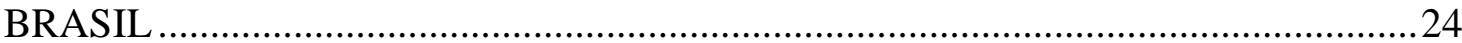

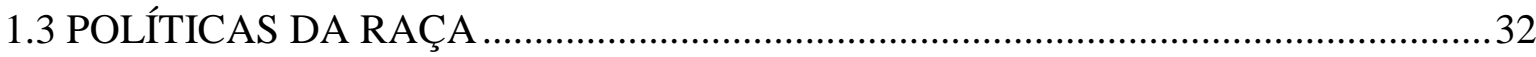

1.4 MOVIMENTO NEGRO E EDUCAÇÃO ANTIRRACISTA.........................................42

1.5 AÇÕES AFIRMATIVAS NO BRASIL .....................................................................47

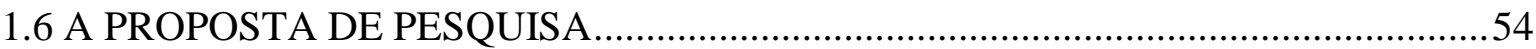

CAPÍTULO 2 A TRAMITAÇÃO LEGISLATIVA DA LEI DE COTAS (LEI No 12.711/2012) .......................................................................................................................56

2.1 PANORAMA SOBRE O AMBIENTE POLÍTICO RELACIONADO ÀS AÇÕES

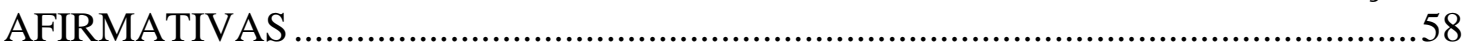

2.1.1 Histórico do Legislativo ..........................................................................................58

2.1.2 Histórico do Executivo ..........................................................................................62

2.2 INFORMAÇÕES BÁSICAS SOBRE PROCESSO LEGISLATIVO ............................67

2.3 TRAMITAÇÃO DO PROJETO DE LEI NA CÂMARA DOS DEPUTADOS .............69

2.4 TRAMITAÇÃO DO PROJETO DE LEI NO SENADO FEDERAL ............................... 81

2.5 CONSIDERAÇÕES FINAIS SOBRE A TRAMITAÇÃO LEGISLATIVA DA LEI DE

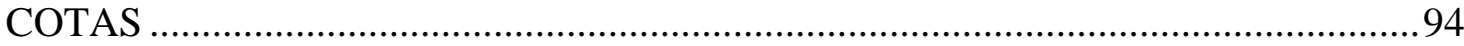

2.5.1 Divergências analíticas sobre o modelo de Lei formulado .............................95

2.5.2 Destaques da tramitação legislativa......................................................................97

CAPÍTULO 3 AUDIÊNCIAS PÚBLICAS SOBRE COTAS NO CONGRESSO NACIONAL .............................................................................................................102

3.1 AUDIÊNCIA PÚBLICA: MECANISMO DE PARTICIPAÇÃO SOCIAL E LEGITIMAÇÃO DAS DECISÕES POLÍTICAS 
3.2 AUDIÊNCIAS PÚBLICAS SOBRE COTAS NA CÂMARA DOS DEPUTADOS ..105

3.2.1 $1^{a}$ Audiência Pública (13/05/2004) - Introduzindo o debate: um diálogo entre o Poder Executivo e o Poder Legislativo ..........................................105

3.2.2 2a Audiência Pública (15/06/2004) - Abrindo espaço para a participação da sociedade civil

3.2.3 $3^{\text {a }}$ Audiência Pública (25/04/2006) - Primeiros embates e divergências públicas no Congresso Nacional 113

3.2.4 4ª Audiência Pública (18/11/2009) - Refletindo sobre as divergências.....122

3.3 AUDIÊNCIAS PÚBLICAS SOBRE COTAS NO SENADO FEDERAL

3.3.1 $1^{\text {a }}$ Audiência Pública (18/12/2008) - Aumento da tensão: as disputas políticas estão à mesa 123

3.3.2 2 $2^{\text {a }}$ Audiência Pública (18/03/2009) - O principal conflito está exposto: as cotas raciais 129

3.3.3 $3^{\text {a }}$ Audiência Pública (02/04/2009) - Última audiência pública: há divergências entre os ideais de Brasil. 134

3.4 CONSIDERAÇÕES FINAIS SOBRE AS AUDIÊNCIAS PÚBLICAS SOBRE COTAS NO CONGRESSO NACIONAL 139

CONSIDERAÇÕES FINAIS. 146

O PROCESSO DE FORMAÇÃO DA LEI DE COTAS 146

RACISMO INSTITUCIONAL E MATRIZ DE DOMINAÇÃO: BREVE REFLEXÃO SOBRE O PROCESSO DE FORMAÇÃO DA LEI A PARTIR DESSAS LENTES.. 152 NOVOS DESAFIOS POLÍTICOS E POSSIBILIDADES DE PESQUISA INEXPLORADAS 


\section{INTRODUÇÃO}

Este trabalho busca investigar como se deu a formação da Lei de Cotas (Lei 12.711/2012) e para tanto enfoca-se principalmente no tramite legislativo dos projetos de lei e nas audiências públicas que ocorreram no Congresso Nacional. A busca por compreender como foi o processo de criação da lei é também uma busca por se entender como a questão racial - até então central nas discussões sobre ações afirmativas no Brasil - perde força e é incorporada nesta Lei como uma sub-subcota.

Antes de seguir apresentando o objeto de pesquisa, os objetivos e o percurso metodológico considero fundamental apresentar-me brevemente, de modo a pontuar qual é o meu lugar de fala e expor a minha relação com o tema. Sou Vanessa Machado, graduada em ciência política pela Universidade de Brasília e mestranda em sociologia pela mesma Universidade. Sou estudante beneficiária das cotas raciais implementadas pela UnB para ingresso de alunos de graduação e também sou cotista racial da primeira turma de pósgraduação, com a política de cotas, do Departamento de Sociologia.

Desde o final da graduação estou próxima e participo de coletivos de estudantes negros $^{1}$ da Universidade, envolvendo-me em eventos, debates e mobilizações relacionadas à temática racial. Como nota-se, políticas de ações afirmativas influenciaram diretamente minha vida e trajetória acadêmica. Portanto, a escolha do meu tema de pesquisa foi motivada pela vivência pessoal dos êxitos e dificuldades dessas políticas, e, principalmente, pelo meu compromisso político-acadêmico com a luta antirracista.

Posto isso, é importante destacar que esta pesquisa foi desenvolvida tendo como referência básica estudos sobre políticas públicas ${ }^{2}$, especialmente aqueles que analisam o período de formação, também conhecido como estágios pré-decisório, da política. Um dos

\footnotetext{
${ }^{1}$ As palavras negro(a)/negros(as) serão constantemente utilizada por este trabalho com o significado político que possui, sendo termo que agrega categorias raciais (pretos e pardos) do Instituto Brasileiro de Geografia e Estatística (IBGE). Baseando-me, também, na definição oferecida pelo Estatuto da Igualdade Racial em seu primeiro artigo, parágrafo único, inciso IV: "população negra: o conjunto de pessoas que se autodeclaram pretas e pardas, conforme o quesito cor ou raça usado pela Fundação Instituto Brasileiro de Geografia e Estatística (IBGE), ou que adotam autodefinição análoga.

${ }^{2}$ A professora Celina de Souza (UERJ) e a professora Maria das Graças Rua (UnB) possuem textos introdutórios e didáticos sobre esse assunto. Políticas Públicas: uma revisão de literatura (2006); Coletânea Políticas Públicas - ENAP (2007) e Análises de políticas públicas: conceitos básicos (1997), respectivamente. Ambos foram referências importantes para este trabalho.
} 
modelos que oferece recursos analíticos para esta pesquisa é o modelo do ciclo de políticas públicas. Esse modelo teórico permite investigar um processo sequencial, observando-se os atores e suas relações, os recursos de poder utilizados, as redes de interação social e algumas práticas desenvolvidas ao longo do processo. Logo a seguir uma ilustração deste modelo.

Figura 1 - Ilustração das etapas do modelo do ciclo de políticas públicas

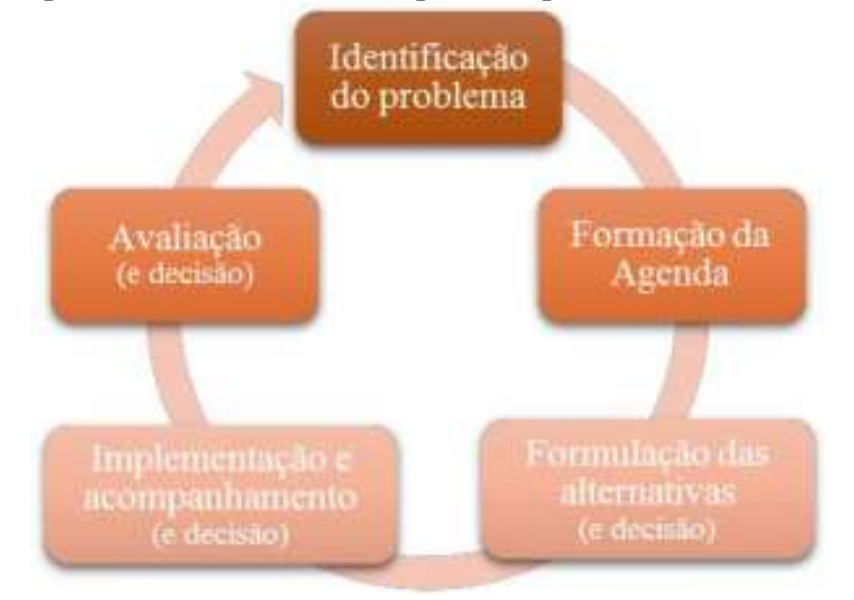

Fonte: Produzido pela autora a partir de referências do modelo.

Esta pesquisa concentra-se em buscar compreender os três primeiros estágios do ciclo das políticas públicas: identificação do problema, formação da agenda política, formulação das alternativas e decisão política. As etapas de implementação, acompanhamento e avaliação da política não estarão contempladas por este trabalho, apesar de serem brevemente mencionadas na conclusão. Entre autores estudiosos de políticas públicas, John Kingdon ${ }^{3}$ destaca-se por seus estudos sobre formação de políticas. Este trabalho também se utiliza das ideias desse autor para desenvolver as reflexões, por exemplo, sobre os principais atores políticos envolvidos na discussão dos projetos de Lei.

Esses modelos teóricos servem sim de referência e base para o desenvolvimento das reflexões aqui propostas, contudo eles não são as únicas fontes de inspiração para a produção desta dissertação. A realidade brasileira, as características de uma sociedade fundada pelo colonialismo e pela escravidão, o desenvolvimento histórico pautado pelas desigualdades e a conformação das instituições formais baseadas em mecanismos excludentes precisam incorporar as reflexões e análises de uma proposta de estudo sócio-político como este. Por isso, é central neste trabalho o conceito de racismo institucional.

\footnotetext{
${ }^{3}$ Em 2003 foi publicada a obra Agendas, Alternatives and Public Policies, em que é apresentado seu famoso Modelo dos Múltiplos Fluxos e suas ideias sobre a formação de políticas públicas, referências para este trabalho. Em 2007, na coletânea sobre Políticas Públicas da ENAP foram publicados artigos do autor sobre o modelo.
} 
Adiante o conceito de racismo institucional será melhor apresentado e debatido, contudo já cabe dizer que a pesquisa compreende racismo institucional a partir da definição de Thula Pires (2013), que afirma:

"O racismo institucional aparece como um sistema generalizado de discriminações inscritas nos mecanismos rotineiros, assegurando a dominação e a inferiorização dos negros sem que haja necessidade de teorizá-la ou justificá-la pela ciência." (PIRES, 2013, p.51)

A pesquisa, portanto, buscou analisar e refletir sobre o processo de formação da Lei de Cotas, preocupando-se primordialmente em como a questão racial perpassou os debates e a tomada de decisão. Sabe-se que esta Lei possui enorme potencial de ampliar a democratização do ensino superior brasileiro, também se reconhece que a inclusão das classes sociais mais pobres nas Instituições de Ensino Superior e Técnico Federais é fundamental para minimização das desigualdades sociais. Entretanto, o foco da análise deste trabalho está em como se tratou a questão racial na formulação dessa lei. A temática das cotas raciais é, ainda hoje, no Brasil algo que gera muitos conflitos, disputas e embates. Entender como as cotas raciais passam a existir como norma no âmbito federal, bem como porque elas são incluídas de modo marginal na Lei, parece-me instigante.

\section{Objeto, objetivos, hipótese e justificativa da pesquisa}

O objeto de pesquisa é a Lei de Cotas (Lei $\left.n^{\circ} 12.711 / 2012\right)$. A questão que guia esta investigação é: Como se formou a Lei de Cotas? E os objetivos dessa pesquisa são: 1) Compreender os mecanismos legislativos formais que levaram à formulação da Lei de Cotas, por meio da análise documental do trâmite legislativo; 2) Compreender as argumentações que estavam presentes naquele contexto, por meio da análise de conteúdo das Audiências Públicas realizadas sobre o tema; 3) Compreender como a principal pauta da discussão - a questão racial - se tornou a menor parcela da reserva de vagas prevista na Lei.

A hipótese principal, que foi sendo construída com o desenvolvimento da pesquisa, é de que o processo de formulação da Lei de cotas foi perpassado pelo racismo institucional brasileiro, formal e informalmente. Assim como será discutido ao longo da dissertação, as instituições podem possuir mecanismos próprios de exclusão; desde a constituição das 
próprias instituições até os resultados que elas entregam à sociedade é possível que existam mecanismos e processos excludentes. Então, no caso do Congresso Nacional e do processo legislativo parece-me que desde a constituição do Sistema Político-Eleitoral Brasileiro, passando pela baixíssima representação política da população negra (não por acaso) até os resultados observados na aprovação das Leis do país, há formas e processos de exclusão dos negros. Em resumo, o trabalho apresenta alguns procedimentos e modos de funcionamento do racismo institucional brasileiro na formulação de uma política.

Algumas das justificativas para a realização desta pesquisa são: 1) buscar suprir lacuna existente na literatura brasileira sobre o processo de formação da Lei de Cotas; 2) contribuir com a sistematização de informações para o debate sobre o formato atual da legislação e suas consequências; e 3) refletir criticamente sobre a lei enquanto política pública e seu impacto para a população negra.

\section{Percurso metodológico}

Trata-se de uma pesquisa qualitativa, que utilizou algumas técnicas para análise dos dados disponíveis, são elas: pesquisa bibliográfica, análise documental, análise de conteúdo e entrevistas. Quanto à pesquisa bibliográfica, como se sabe, é característica de trabalhos acadêmicos em que se estude profundamente o campo para iniciar a própria produção. Para o desenvolvimento deste trabalho alguns temas foram estudados com afinco, entre eles estão: ações afirmativas, relações raciais no Brasil, políticas públicas educacionais e processo legislativo.

Sobre a análise documental, foram selecionados documentos oficiais disponíveis nos sites da Câmara dos Deputados e do Senado Federal. Analisei os projetos de lei em trâmite relacionados à Lei de Cotas; os pareceres dos relatores das Comissões; os Votos em separado apresentados por parlamentares que discordavam da proposta principal em andamento e as decisões dos plenários da Câmara dos Deputados e do Senado Federal. Além disso, descrevi como ocorreu a tramitação legislativa em si, seguindo as informações virtualmente disponibilizadas pelas Casas legislativas estudadas. 
Sobre a análise de conteúdo, foram selecionadas notas taquigráficas de sete audiências públicas sobre cotas, que aconteceram no Congresso Nacional. Analisei as falas proferidas nesses eventos, buscando identificar linhas de argumentações favoráveis e contrárias às cotas. A partir das notas taquigráficas, também, foi possível identificar os principais atores políticos que influenciaram a tramitação da matéria. A análise de conteúdo permitiu a este trabalho desenvolver reflexões sobre a perpetuação, a reificação e as novas formas do mito da democracia racial, o que considero um dos pilares do racismo institucional no Brasil.

Também foram realizadas duas entrevistas-diretivas, que serviram de guia para a pesquisa documental. Renato Ferreira ${ }^{4}$ e Mário Theodoro ${ }^{5}$ gentilmente se disponibilizaram a dialogar sobre o que viram e viveram nesse processo de formação da Lei. As entrevistas tiveram o objetivo de conhecer, a partir da perspectiva de quem viveu o processo, como aconteceram as disputas e os debates, no período.

\section{Estrutura da dissertação}

Seguimos para breve explicação sobre a estrutura do trabalho, cada capítulo e seus conteúdos. O primeiro capítulo é um esforço para apresentar os principais conceitos utilizados no trabalho; as principais referências nos estudos sociais sobre relações raciais e sobre ações afirmativas; há uma contextualização histórica de como o movimento negro tem trabalhado pela educação antirracista; e considero que a principal ideia do capítulo é a defesa de que o país possui um histórico de legislações racializadas, o que denominei de políticas da raça.

O segundo capítulo aprofunda a contextualização política do período em que tramitou a Lei de Cotas. Também apresenta - descrevendo e analisando - o processo de tramitação legislativa dos projetos de lei que deram origem à Lei de Cotas. O terceiro capítulo discute a conceituação e os objetivos que os órgãos públicos perseguem ao realizar audiências públicas.

\footnotetext{
${ }^{4}$ Entrevista realizada em 30/10/2015. Renato Ferreira é advogado que trabalha com questões de direitos humanos e relações raciais, foi chefe da assessoria parlamentar da Secretaria de Políticas de Promoção da Igualdade Racial (SEPPIR) em parte do período de tramitação dos projetos de lei, e participou de várias reuniões relacionadas ao tema no Congresso Nacional.

${ }^{5}$ Entrevista realizada em 10/11/2016. Mário Theodoro é doutor em economia pela Université Paris I - Sorbonne, e atualmente é consultor legislativo do Senado Federal. Foi Secretário Executivo da SEPPIR em parte do período de tramitação dos projetos de lei, e participou de várias discussões sobre o assunto no Congresso Nacional.
} 
Os temas abordados e alguns pontos de discussão dessas audiências públicas são apresentados. Além disso, este capítulo busca compreender em qual momento histórico cada audiência pública aconteceu, tentando conectar o que foi debatido pelos participantes com o que estava ocorrendo externamente naquele período.

O quarto e último capítulo resume os principais achados da pesquisa, discute analiticamente como se deu o processo de formação da lei, quais os principais atores envolvidos, quais as principais argumentações favoráveis e contrárias, destacando alguns embates e contradições de todo esse processo de construção da lei. Além disso, apresenta-se com maior detalhamento o conceito de racismo institucional em algumas produções brasileiras sobre o tema e, também, a ideia de matriz de dominação de Patrícia Hill Collins (2000) procurando analisar e refletir sobre o processo de formação da Lei de cotas a partir do ponto de vista dessas teorias. Por fim, foram feitos apontamentos de novos desafios políticos que se colocam com a existência da Lei, que também são temas de pesquisa inexplorados a serem estudados.

O contexto político, social e econômico em que comecei a pensar e a desenvolver esta pesquisa (2014/2015) é completamente diferente do contexto que possuímos no momento da apresentação deste trabalho (2017). De minha parte não havia nenhuma expectativa de que realmente pudessem destituir do poder uma Presidenta democraticamente eleita. Esse acontecimento tem repercutido de modo catastrófico sobre as políticas públicas sociais, e sobre as condições de vida da população mais pobre e negra. Sendo assim, me parece que estudar a formação da Lei de Cotas por uma perspectiva afrocentrada é um modo de resistência e de disputa de narrativa. Somando-me aos que utilizam a expressão "Nada sobre nós, sem nós", defendo que pessoas negras cada vez mais participem das discussões e decisões que influenciam a vida da população negra. Seguindo as ideias de Luiza Bairros ${ }^{6}$ (1995) queremos pensar um projeto político-social-econômico maior:

Estamos apostando hoje na possibilidade de disputar não mais um espaço dentro de outros projetos para as nossas questões, que são tidas como menores. Mas nós estamos apostando na possibilidade de que, através de nossas questões, nós consigamos efetivamente tocar, e tocar muito fundo, nas questões que dizem respeito a sociedade [brasileira] como um todo.

\footnotetext{
${ }^{6}$ Trecho retirado do documento produzido pela organização da Marcha Zumbi dos Palmares de 1995. Luiza Bairros foi importante ativista e intelectual negra brasileira, foi Ministra da Secretaria de Políticas de Promoção da Igualdade Racial (SEPPIR) de 2011 a 2014.
} 


\section{CAPÍTULO 1}

\section{ASPECTOS BASILARES PARA A COMPREENSÃO DA LEI DE COTAS}

\subsection{SOBRE RAÇA, RACISMO E RACISMO INSTITUCIONAL}

Abordar a temática racial no Brasil, em especial nas ciências sociais, é uma escolha desafiadora e cheia de complexidades. A começar pelo fato de que foram intelectuais das ciências sociais brasileira que formularam e difundiram a ideia de que o Brasil se configurava como uma democracia racial. Tal argumentação usufruiu de tanto prestígio e aceitação no tecido social brasileiro que até hoje, muitos anos após serem apresentados dados contundentes que se contrapõe a essa teorização, continua sendo indispensável abordá-la, questioná-la e desconstruí-la. Por isso, me proponho a iniciar esse trabalho refletindo brevemente sobre os conceitos de raça, racismo e racismo institucional, essenciais para se pensar a problemática abordada nesta dissertação.

De acordo Guimarães (2009), no século XVI o termo raça era utilizado em sentido literário, significando "um grupo ou categoria de pessoas conectadas por uma origem comum" (apud. Banton, 1994), séculos mais tarde o conceito de raça aparece nas teorias biológicas. Conforme expõe Munanga (2000), de modo geral, as classificações e os conceitos científicos são utilizados para ser possível operacionalizar os pensamentos, por isso as ciências biológicas buscaram desenvolver mecanismos de classificação dos seres vivos. É nesse sentido, que a categoria raça é utilizada a princípio.

No século XVIII, entre outras categorizações realizadas, passou-se a considerar a cor da pele um critério importante na classificação dos seres humanos, para identificação das raças. A partir desse período a espécie humana foi dividia em três raças: branca, amarela e negra. O século XIX acrescentou à característica da cor da pele, critérios morfológicos como, por exemplo, o formato do nariz, dos lábios, do queixo, do crânio. Tais classificações em si não eram problemáticas, mas se tornaram uma dificuldade a partir do momento em que foram associadas à hierarquização, possibilitando, então, um caminho para o racialismo (MUNANGA, 2000).

No século XX, a partir dos estudos sobre genética, descobriu-se que no sangue haviam critérios químicos mais relevantes para se dividir a humanidade em raças, como por exemplo, 
algumas doenças hereditárias que poderiam ser encontradas em algumas raças mais do que em outras. A partir daí, realizando cruzamentos entre os critérios de cor de pele, critérios morfológicos e os critérios genéticos notou-se que era possível existirem dezenas de raças e sub-raças, bem como identificou-se que indivíduos da mesma raça podiam ter patrimônios genéticos muito diferentes.

Tais análises, juntamente com outros progressos das ciências biológicas, concluíram que raça não é uma realidade biológica. Sendo assim, biólogos consideram o conceito cientificamente inoperante para explicar a diversidade da humanidade atualmente, ou seja, biologicamente raças não existem (MUNANGA, 2000).

O maior problema não está nem na classificação como tal, nem na inoperacionalidade científica do conceito de raça. Se os naturalistas dos séculos XVIII-XIX tivessem limitado seus trabalhos somente à classificação dos grupos humanos em função das características físicas, eles não teriam certamente causado nenhum problema para a humanidade. Suas classificações teriam sido mantidas ou rejeitadas como sempre aconteceu na história do conhecimento científico. Infelizmente, desde o início, eles se deram o direito de hierarquizar, isto é, de estabelecer a escala de valores as chamadas raças. (MUNANGA, 2000, p. 21)

Nesse sentido, assim como indica Kabengele Munanga (2000), desde o início a classificação racial associou o biológico (cor da pele, traços físicos) com qualidades psicológicas, morais, intelectuais e culturais. Sendo os indivíduos da raça "branca" entendidos coletivamente como superiores aos da raça "negra" e "amarela". Giddens (2005) explica que a classificação hierarquizada de raças deu base a uma teoria científica, que se desdobrou em ideologia política. Tais ideologias fundamentaram catástrofes como o nacionalismo nazista na Alemanha, a aparição de grupos de supremacia branca como a $\mathrm{Ku}$ Klux-Klan nos Estados Unidos, e o sistema político-social do apartheid na África do Sul, por exemplo.

Guimarães (2009) relata que após a Segunda Guerra, a UNESCO realizou três reuniões entre biólogos, geneticistas e cientistas sociais com o objetivo de avaliar o campo de estudos sobre raças e relações raciais, em 1947, 1951 e 1964. As conclusões desses encontros explicitaram que as diferenças fenotípicas entre indivíduos e grupos humanos, bem como as distinções culturais, morais e intelectuais não estão relacionadas, diretamente, às diferenças biológicas, "mas devem ser creditadas a construções socioculturais e a condicionantes ambientais" (GUIMARÃES, 2009, p.24). Sendo assim, a utilização do termo raça atualmente 
não tem sentido biológico, mas é utilizado como um conceito necessário para a exposição das relações de poder e dominação decorrentes do período colonial e escravagista.

Sabe-se que atualmente o conceito incorpora um conteúdo político-ideológico, prova disso é a variação que há na identificação entre negro, branco e amarelo a depender do país. Há diferenças importantes ao se identificar, por exemplo, negros no Brasil e nos Estados Unidos. Em discussões recentes há recomendação de biólogos antirracistas para a não utilização do termo raça em trabalhos científicos. A discussão sobre a continuidade ou não da utilização desse termo se estende também às ciências sociais.

Há quem defenda o não uso da categoria raça por sua característica de essencialização e por ser uma categorização muito carregada ideologicamente, em substituição preferem a utilização do termo etnia, por ser um conceito mais amplo. Segundo Giddens (2005), eles argumentam “(...) que raça não passa de um constructo ideológico, cuja utilização nos círculos acadêmicos apenas perpetua a convicção comum da existência de um fundamento biológico" (apud. MILES, 1993).

No entanto, este trabalho se junta aos que defendem a manutenção do uso da categoria com base na realidade social e política, compreendendo raça como uma construção sociológica e política. Posto o histórico científico da constituição do termo e seus desdobramentos como o colonialismo e a escravidão africana, este trabalho compreende que a utilização da categoria raça é indispensável para analisar as relações de poder, privilégio e dominação que se estabeleceram em sociedades pós-coloniais, como a brasileira. Além disso, acredita-se que o entendimento aprofundado das relações de poder baseado em critérios raciais pode embasar a construção de políticas e ações que revertam as desigualdades raciais.

É necessário apresentar aqui a definição de racismo a ser mobilizada ao longo deste trabalho. Compreende-se racismo, a partir das ideias de Munanga (2000), como a crença na existência de raças naturalmente hierarquizadas pela relação intrínseca entre traços físicos e biológicos com características culturais, psicológicas, morais, intelectuais e estéticas. Sendo, portanto, o racismo uma "tendência que consiste em considerar que as características morais e intelectuais de um dado grupo, são consequências diretas de suas características físicas ou biológicas" (MUNANGA, 2000, p. 24). 
Por se tratar de um trabalho sociológico, não é possível abordar racismo desconsiderando que uma de suas origens está ligada ao modernismo ocidental. Com a secularização do pensamento, ou seja, com a busca por se formular o conhecimento não mais com base na religião, mas sim na ciência, o determinismo biológico se torna eixo central para a compreensão da história humana.

Assim sendo, características físicas foram diretamente relacionadas ao comportamento de cada povo. E essa relação direta estabelecida entre o biológico e o intelectual e o biológico e o moral originou a divisão entre raças superiores e inferiores. Como se sabe, essas ideias embasaram e legitimaram o domínio colonial dos europeus sobre povos não-brancos, negando-lhes a humanidade e os direitos.

Assim como expõe Gilroy (2001) em sua obra - O Atlântico Negro - a intelectualidade modernista teve especial importância na criação e consolidação de concepções racistas. Na produção intelectual hegemônica sobre a modernidade a temática da escravidão aparece de modo marginal ou reiterando as associações racistas entre o biológico e o intelectual. A partir desse autor é possível observar a modernidade por outra perspectiva, considerando a contracultura do período moderno e colocando no centro as experiências de terror racial e racismo. Conforme suas ideias, a partir da Fenomenologia do espírito de Hegel é possível iniciar uma nova forma de análise moderna utilizando como conceitos-chave a associação entre modernidade e escravidão.

Isto é importante por ela [a teoria de Hegel] poder ser usada para oferecer uma firme rejeição da ideia hipnótica da história do progresso e porque ela propicia uma oportunidade de reperiodizar e reacentuar narrativas da dialética do Iluminismo que nem sempre têm se preocupado em olhar para a modernidade pela lente do colonialismo ou do racismo científico. (GILROY, 2001, p. 122-123)

Conforme Gilroy (2001), para se compreender a modernidade, e inclusive para se discutir a pós-modernidade, é relevante entender a escravidão para além de um sistema de mão de obra capitalista ou de um modo de dominação racial. Mais do que isso, o sistema escravocrata forneceu as fundamentações para a existência das redes de relações econômicas, sociais e políticas tal como existem hoje. Atendo-se especificamente a essa parte do pensamento desenvolvido pelo autor, este trabalho faz coro à proposta de se pensar a modernidade e suas propostas universalistas considerando a escravidão como parte essencial desse processo. 
Posto isso, torna-se uma tarefa importante e necessária tratar das consequências geradas pelas formulações racistas dos últimos séculos, dentre elas está o fato de o imaginário popular haver incorporado a ideia de superioridade-inferioridade, relacionando-as com características biológicas. Sendo assim, este estudo, que buscará compreender a formação da lei de cotas do ensino superior brasileiro, necessariamente precisa incorporar, também, a discussão sobre raça e racismo que integraram o debate. Apesar de biologicamente raça não existir, a categoria segue presente nas representações e nos imaginários coletivos bem como, por razões históricas e políticas, o quesito racial tem determinado o acesso às condições de cidadania e bem-estar social.

Vale ressaltar, também, que ao se utilizar o termo raça e ao se identificar as pessoas como negras ou brancas, sabe-se que há dentro dessas categorias grande pluralismo histórico e cultural. Contudo, a utilização política desses termos, propõe "uma identidade unificadora em busca de propostas transformadoras da realidade do negro no Brasil" (MUNANGA, 2000, p.31).

Outra expressão indispensável para a leitura e compreensão deste trabalho é o conceito de racismo institucional. Essa ideia foi pensada inicialmente nos anos 1960, nos Estados Unidos, no contexto das lutas por direitos civis. A proposta é de compreender o racismo para além dos comportamentos individuais ou de pequenos grupos, entendendo-se que ele se sustenta a partir do próprio tecido social. A ideia de racismo institucional sugere, então, que o racismo permeia as estruturas da sociedade de modo sistemático. Sendo que instituições como a polícia, os serviços de saúde e o sistema educacional desenvolvem práticas que favorecem certos grupos em detrimento de outros (GIDDENS, 2005).

De acordo com Ivair dos Santos (2013), em 1967 integrantes do movimento negro norte-americano - Stokely Carmichael e Charles Hamilton - ao escreverem o livro Black Power: the politics of libertation expuseram as diferenças entre o racismo individual e explícito e o racismo institucional ou não-declarado. Essa formulação permite a dissociação do racismo como sendo necessariamente vinculado às intenções e à consciência de certos indivíduos. Ainda segundo Santos (2013), essa ideia foi desenvolvida por vários autores como Jones (1973), Rex (1988) e Wieviorka (2007). Destaca-se, portanto, como o conceito de racismo institucional propõe uma dissociação entre o ator e o sistema em termos analíticos, ou seja, pressupõe-se que o racismo pode funcionar de modo institucional independentemente das opiniões ou preconceitos dos atores. 
Principalmente a formulação de Wieviorka (2007) propõe uma forma de raciocínio em que, por exemplo, quando brancos querem manter o status quo sendo contrários a modificações institucionais, não necessariamente eles apresentam argumentos racistas, porém articulam outros tipos de justificativas mesmo conscientes das desigualdades apresentadas por indicadores sociais. Nesse caso, enquanto as causas do racismo se apresentam camufladas, seus efeitos são evidentes. (SANTOS, 2013)

\begin{abstract}
A força da ideia do racismo institucional está em denunciar a discriminação racial dissimulada, e em levar à consciência de que não é possível esperar que espontaneamente e de maneira voluntária, ocorram mudanças nas condições sociais da população negra; é preciso investimento das instituições. (...) é um convite para o debate, a investigação, a recusa à cegueira, que em virtude das barreiras que as instituições se auto impõem, permite a amplas parcelas da população beneficiar-se das vantagens econômicas e estatutárias que o racismo ativo pode trazer e, ao mesmo tempo, evitar assumir seus inconvenientes morais. (SANTOS, 2013, p. 26)
\end{abstract}

Por se tratar de um tema complexo e multifacetado, ainda que o conceito busque ampliar a compreensão do fenômeno, ele também possui limitações. Como reconhece o próprio autor, o termo racismo institucional tem a deficiência de tornar o racismo um fenômeno abstrato, por que é proveniente de mecanismos abstratos, em que os atores têm importância menor. Todavia, para os objetivos deste trabalho, mesmo reconhecendo-se limitações no conceito, essa proposta é muito interessante.

O racismo institucional se demonstra através de estratégias e mecanismos que impendem o acesso de parcelas da população a lugares de privilégio e poder, por exemplo. Sendo que no dia-a-dia o racismo institucional garante a manutenção das relações de dominação, tornando-se naturalizado e é internalizado em países que, como o Brasil, possuem altos níveis de miscigenação (SANTOS, 2013).

\title{
1.2 ESTUDOS SOBRE RELAÇÕES RACIAIS E RACISMO NA CIÊNCIA SOCIAL DO BRASIL
}

Como se sabe, o Brasil é, contemporaneamente, uma das maiores sociedades multirraciais e multiculturais do mundo. Nas primeiras décadas do século XX, o país foi descrito e interpretado como uma democracia racial; onde pretos, pardos, indígenas e brancos viviam em harmonia e em condições jurídicas igualitárias, com condições sociais favoráveis a 
todos. Na segunda metade do século, o debate sobre relações raciais foi marcado pela desconstrução desse mito por meio de manifestações constantes do movimento negro, dados estatísticos e análises qualitativas da realidade.

A partir de 1940, os censos nacionais passaram a documentar a existência de disparidades muito significativas entre brancos e não-brancos, em relação à educação, trabalho, renda e expectativa de vida, por exemplo. A democracia racial foi originalmente concebida em um contexto em que era necessário legitimar e justificar o domínio autoritário e oligárquico das elites do país, porém, na medida em que críticas democráticas passaram a enfrentar o governo a conceituação de que o país vivia uma democracia racial foi sendo colocada em dúvida.

Assim como defende Andrews (1997), para além de fatores políticos especificamente internos ao país, a desconstrução do mito da democracia racial conta também com análises internacionais e teorizações externas. Segundo este autor, é necessário se considerar também os fluxos de ideias, práticas e as instituições transnacionais como parte dos acontecimentos históricos e das formulações teóricas nas sociedades modernas.

Desse modo, sabe-se que as doutrinas de racismo científico anteriormente mencionadas, que deram origem às ideias de raças hierarquizadas, também impactaram a formação do pensamento social brasileiro. O prestígio da ciência europeia fez com que a concepção de superioridade racial dos brancos encontrasse terra fértil no Brasil. Sendo que, após a abolição da escravatura, a partir de 1888, uma das maiores preocupações de intelectuais e políticos brasileiros era 'melhorar' a raça no país. As previsões de futuro para um país constituído majoritariamente por não brancos era melancólica e catastrófica.

Nesse cenário, a tese do branqueamento aparece como uma grande esperança para o país, que pretendia integrar a comunidade de nações brancas. Essa formulação inicialmente científica e, em seguida, adaptada para a política, previa que na mistura de raças prevalecia o componente genético branco, e se essa mistura ocorresse por muitas gerações, o resultado final seria ter uma população embranquecida, em que as ancestralidades africanas e indígenas seriam neutralizadas e superadas. 
Aplicando na prática essa proposta, em 1890, o Decreto $528^{7}$, sujeitou a entrada de africanos no Brasil à autorização do Congresso. Os governos tanto federal como estaduais se empenharam de modo coordenado na busca por atrair imigrantes europeus. Conforme demonstra Andrews (1997) em seus estudos, pesquisadores celebravam a tendência à arianização do Brasil, alegando que os dados do censo de 1920 demonstravam aumento do coeficiente da raça branca.

Todavia, esse documento, de acordo com Andrews (1997), não possuía nenhuma informação sobre a composição racial da população do país. Ainda assim, essa percepção traz à tona conflitos e tensões raciais decorrentes desse modelo de política. Note-se que o começo do século XX no Brasil foi marcado por ações, como por exemplo, o incentivo ao branqueamento, o incentivo à imigração europeia, a proibição da imigração africana e a não concessão de visto para negros norte-americanos, políticas nitidamente racialistas.

Por outro lado, no mesmo período prevaleceu tratamento diferenciado aos europeus com a concessão de terras, capacitação e empregos, ou seja, o Estado brasileiro ofereceu as condições mínimas necessárias para que essas populações se estabelecessem socialmente. Ao passo que, para o povo negro houve o processo desumano da escravidão e, após a abolição, eles foram relegados à própria sorte, sem nenhum mecanismo efetivo de inclusão. Dado esse contexto, me parece razoável afirmar que o Estado brasileiro incentivou e foi um produtor de desigualdade racial, por meio de mecanismos institucionais, estabelecendo políticas racializadas e discriminatórias.

Com a chegada de imigrantes europeus, aumentou-se a competitividade por trabalho, e os ex-escravos foram muito afetados por esta política. A competição por trabalho tornou evidente, nos anos de 1920 e 1930, certo descontentamento com a europeização. Prova disso é que o governo do Estado de São $\mathrm{Paulo}^{8}$, um dos estados mais afetados pela imigração, nas primeiras décadas do século XX retirou os incentivos concedidos a imigrantes europeus; ao passo que em 1930 o governo federal ${ }^{9}$ passou a restringir a imigração no país e, também, o emprego na indústria e comércio para estrangeiros (ANDREWS, 1997). Outro decreto que evidencia a visão do país sobre sua composição racial é o Decreto-lei 7.967/1945 ${ }^{10}$, que foi

\footnotetext{
${ }^{7}$ Decreto no 528/1890, disponível em: http://legis.senado.gov.br/legislacao/ListaNormas.action?numero=528\&tipo_norma=DEC\&data=189006 $28 \&$ link $=\mathrm{s}$

${ }^{8}$ Decreto ${ }^{\circ}$ 2533/1914, Assembleia Legislativa do Estado de São Paulo (por exemplo). Disponível em: http://www.al.sp.gov.br/repositorio/legislacao/decreto/1914/decreto-2533-16.09.1914.html

${ }^{9}$ Decreto no 19.482/1930, Getúlio Vargas. Disponível em: http://www2.camara.leg.br/legin/fed/decret/19301939/decreto-19482-12-dezembro-1930-503018-publicacaooriginal-1-pe.html
} 
uma legislação para tratar de imigração no país, e prevê em um de seus artigos " $a$ necessidade de preservar e desenvolver, na composição étnica da população, as características mais convenientes da sua ascendência europeia”.

A institucionalização de tais políticas demonstra o vínculo existente entre a política estatal brasileira e o racismo institucional, como já apresentado por Valter Silvério (2002). Esse autor afirma ainda que a presença do Estado foi decisiva na configuração de uma sociedade formada com profunda exclusão de alguns segmentos, em especial, os negros. Como nota-se ativamente o Estado brasileiro implementou políticas que beneficiavam certos grupos raciais em detrimento de outros, com objetivo específico de branqueamento da população.

No entanto, o projeto de branqueamento do Brasil fracassou, e novamente foi necessário pensar um caminho de desenvolvimento para o país e de formação da identidade nacional. Para se pensar a construção de um projeto político nacional é fundamental incluir a questão racial. Nesse contexto, em 1933 o teórico social Gilberto Freyre apresentou uma proposta de interpretação do Brasil alternativa à busca pelo branqueamento e pela não degeneração nacional. Freyre foi o primeiro acadêmico brasileiro a aceitar que o país não era branco, nem europeu, e que nunca o seria.

Gilberto Freyre propôs um novo modelo de sociedade, caracterizando o Brasil como um experimento em que europeus, índios e africanos se juntavam para criação de uma sociedade multirracial. Esse autor formulou ideias que posteriormente embasaram uma concepção do Brasil como democracia racial, em que harmoniosas uniões entre a cultura e a natureza de distintos povos ocorreram. Essa junção se corporifica na figura do mulato, que seria a representação da integração racial. Essa formulação teórica encontrou muita receptividade em diversos segmentos da sociedade brasileira. Nas décadas seguintes, em 1940 e 1950, os círculos acadêmicos, a mídia, os políticos, os servidores públicos e as escolas repercutiam e propagavam essa ideia.

Prova de que esse pensamento teve força e disseminação é, por exemplo, o discurso do chanceler brasileiro na sessão ordinária da Assembleia Geral das Nações Unidas em 1966, que afirmou:

10 Decreto-lei no 7967/1945, disponível em: http://www.planalto.gov.br/ccivil_03/decreto-lei/19371946/Del7967.htm 
No campo dos problemas sociais e das relações humanas, o Brasil orgulha-se de ter sido o primeiro país a assinar a Convenção Internacional sobre a Eliminação de Todas as Formas de Discriminação Racial, aprovada pela última sessão da Assembléia Geral. Dentro das fronteiras do Brasil, na realidade, tal documento não seria tão necessário, uma vez que o Brasil é há muito tempo um exemplo proeminente, e eu diria até o primeiro, de uma verdadeira democracia racial, onde muitas raças vivem e trabalham juntas e se mesclam livremente, sem medo ou favores, sem ódio ou discriminação. (SILVA, 2008, p.69 e 70, grifo meu)

Apesar das críticas de agentes negros produzidas tanto individual como coletivamente, nos circuitos intelectuais oficiais, a hegemonia desse paradigma persistia. Para que essa concepção começasse a ser abalada foi necessário que outros intelectuais, impulsionados por agências internacionais, se propusessem a compreender com maior profundidade a dinâmica racial brasileira. No início de 1950, a Organização Educacional, Científica e Cultural das Nações Unidas (UNESCO), em resposta as atrocidades presenciadas pelo nazismo e holocausto, estabeleceu como uma de suas missões institucionais o enfrentamento ao racismo.

Nesse contexto a democracia racial brasileira parecia ser promissora. Em um esforço por compreender as condições e práticas racialmente igualitárias do Brasil formulou-se o denominado Projeto Unesco. A execução do projeto se estendeu a várias cidades brasileiras, e surpreendendo o mito da democracia racial - academicamente consolidado e incorporado ao discurso popular - os resultados encontrados demonstraram elevados níveis de desigualdade racial e apresentarem evidências de que ocorriam práticas discriminatórias baseadas em estereótipos racistas no país.

Também em 1950, um episódio marcara negativamente a imagem do Brasil, a dançarina afro-americana Katherine Dunham teve sua reserva em um hotel de São Paulo cancelada por ser negra. Práticas como essa eram comuns no país, contudo a fama internacional desta dançarina fez com que o ocorrido ganhasse grande repercussão, tendo como consequência política a criação da primeira norma antirracista do país - a Lei Afonso Arinos (1951).

Estes dois fatos - os resultados do projeto UNESCO e o caso de racismo com Katherine Dunham - constrangeram a academia brasileira a admitir que havia falhas na concepção de democracia racial no Brasil. A partir deles nota-se que novos modos de se pensar as relações raciais no Brasil começaram a ser produzidos por centros de pesquisa prestigiados, como a Universidade de São Paulo. São exemplos disso, o sociólogo Florestan Fernandes e o antropólogo Roger Bastide bem como seus alunos Fernando Henrique 
Cardoso $^{11}$ e Octávio Ianni ${ }^{12}$. Paralelamente, intelectuais negros formularam suas interpretações da sociedade brasileira, que divergiam e, inclusive, negavam o mito hegemônico, como é o caso de Guerreiro Ramos ${ }^{13}$, Edson Carneiro ${ }^{14}$ e Abdias do Nascimento ${ }^{15}$.

Para ilustrar as divergências manifestas nos escritos de intelectuais negros, abaixo destaca-se dois pontos da obra Introdução Crítica à Sociologia de Guerreiro Ramos. O autor apresenta a declaração de princípios formulada na Semana de Estudos do Teatro Experimental do Negro em 1955, iniciativa que se propôs a realizar um balanço dos estudos sociológicos e antropológicos sobre o negro no Brasil. Desse modo, os pontos abaixo não são a opinião exclusivamente do autor, mas de um grupo de pensadores reunidos na ocasião.

“(...) Declara:

1. É desejável que os organismos internacionais, cujo o objetivo nominal é estimular a integração dos povos, sejam cada vez mais encorajados a discutir medidas concretas tendentes à liquidação do colonialismo, em todas as suas formas e matizes, uma vez que a mera proclamação de direitos e princípios, sob forma acadêmica e em abstrato, pode prestar-se (e frequentes vezes se tem efetivamente prestado) para a coonestação da injustiça e da espoliação. (....)

2. É necessário desenvolver a capacidade crítica dos quadros científicos, intelectuais e dirigentes dos povos e grupos de cor, afim de que eles se tornem aptos a discernir nas chamadas ciências sociais o que é mera camuflagem e sublimação de propósito espoliativos e domesticadores e o que é objetivamente positivo na perspectiva das sociedades ditas subdesenvolvidas." ( RAMOS, 1957, p. 250 e 251)

Tais relatos demonstram que na década de 1950 havia preocupação por parte de intelectuais negros na efetivação de direitos para reparação de injustiças e que essa ação poderia partir de organismos internacionais, bem como precisavam ir além do plano acadêmico e abstrato. Além disso, nota-se que há a percepção da necessidade de existir cada vez mais intelectuais negros críticos capazes de analisar e discernir as proposições das ciências sociais no país, de modo a identificar os fatores positivos dessas produções, bem como se contrapor aos fatores negativos. Nesse sentido é possível observar em Guerreiro Ramos uma maneira alternativa e autêntica de se refletir sobre relações raciais no Brasil.

A segunda metade do século XX foi marcada por divergências e desestabilização da compreensão do Brasil como democracia racial. O regime militar reagiu argumentando que as

\footnotetext{
${ }^{11}$ Escravidão e racismo (1978)

${ }^{12}$ Raças e Classes sociais no Brasil (1970)

${ }^{13}$ Introdução crítica à sociologia (1957)

${ }^{14}$ Ladinos e crioulos (1964)

${ }^{15}$ O negro Revoltado (1982)
} 
críticas à democracia racial eram 'atos de subversão' realizadas pela esquerda que procurava criar novos pontos de tensão social, além de ampliar a insatisfação com o regime e as autoridades constituídas. Alinhando-se a esse discurso, Gilberto Freyre afirma que esses 'pseudo-sociólogos e comunistas' agiam de maneira antibrasileira ${ }^{16}$.

As pesquisas em ciências sociais sobre a temática nos anos 70 e 80 foram ainda mais críticas e contundentes sobre a situação social do negro. Isto é, uma parcela dos pesquisadores dos anos 50 haviam concluído que a desigualdade e discriminação racial eram uma sobrevivência arcaica do período da escravidão, e previam que seria possível superá-las com o desenvolvimento e a modernização capitalista, que abririam oportunidades para mobilidade ascendente dos negros; os estudiosos das décadas de 70 e 80 observaram a partir de análises estatísticas a nítida desvantagem social dos não brancos, suas pesquisas comprovavam que mesmo quando os negros possuíam níveis competitivos de experiência profissional e formação, eram preteridos em favor de brancos menos capacitados, no que se refere aos rendimentos e às promoções.

Os resultados desses estudos ${ }^{17}$ concluíam, por exemplo, que quanto maior era o nível educacional dos negros concorrendo por vagas de trabalho, mais desvantagens possuíam em relação aos brancos em busca de empregos. Situação não muito diferente da atual conforme apresenta a publicação As Políticas Públicas e desigualdades raciais (IPEA, 2008), que expõe o racismo institucional como um elemento importante para que haja tratamento desigual entre bancos e negros nos serviços públicos, nos benefícios e nas oportunidades sociais.

Estudos sociológicos realizados a partir da década de 1970 colocaram em evidência uma relevante questão a ser abordada nessa pesquisa que são as desigualdades raciais na educação. Esse período também foi rico pela produção de afro-brasileiros que observavam, e ao mesmo tempo, vivenciavam barreiras raciais que impediam a ascensão social do negro e condições de vida digna. Tais estudos empíricos constituíram críticas cada vez mais severas sobre a (in)existência de uma democracia racial no Brasil.

Conforme aponta Andrews (1997), se em um primeiro momento intelectuais norteamericanos aderiram à concepção de democracia racial, por volta dos anos 1940 autores como

\footnotetext{
${ }^{16}$ De acordo com o texto de Andrews (1997), Freyre fez essa afirmação em um artigo denominado 'A propósito de preconceito de raça no Brasil', O Estado de São Paulo, 25 de junho de 1969.

${ }^{17}$ Carlos Hasenbalg: Discriminação e desigualdades raciais no Brasil (1979) e Nelson do Valle Silva: Estrutura social, mobilidade e raça (1988).
} 
DuBois passaram a desenvolver uma percepção crítica sobre a mistura racial celebrada por Freyre, como se observa no trecho abaixo de Andrews (1997):

(...) não imagina nenhuma diminuição de poder e prestígio entre os brancos... mas, antes, uma inclusão dentro do assim chamado grupo branco de uma considerável infiltração de sangue negro, ao mesmo tempo em que mantém a barreira social, a exploração econômica e a privação de direitos políticos do sangue negro como tal... Portanto, o amálgama racial na América Latina nem sempre e nem habitualmente carrega consigo a ascensão social e o esforço planejado para levar o mulato e os mestiços à liberdade numa sociedade civil democrática." (apud. DUBOIS, p. 106)

No final do século XX com os fluxos de informação global, o país passou a rever sua percepção sobre as relações raciais, influenciado por pressões internas de movimentos e militantes negros e, também, pelos dados das pesquisas sociais nacionais e internacionais. Cabe refletir sobre como essas formulações acadêmicas influenciaram e dirigiram algumas políticas nacionais.

Ou seja, a partir dessas ideias debatidas no âmbito acadêmico uma visão de Brasil e concepções de como deveriam ser as instituições, as políticas e as leis foram formuladas. Discriminação e racismo são componentes essenciais na estruturação da sociedade brasileira, operando não apenas no plano individual, mas muito mais no plano institucional ou estrutural, conforme afirma Valter Silvério (2002).

A Constituição Federal de 1988 inova e apresenta uma espécie de ponto de virada normativo por tratar a questão racial de maneira mais abrangente do que havia sido até então. A inclusão da temática racial na Constituição de 1988 é relevante, uma vez que a essa norma pode ser compreendida “(...) como um instrumento fundador do ordenamento jurídico e também como um paradigma orientador da sociedade civil através de seus princípios positivados e objetivos pragmáticos" (MARTINS, 1996). No mesmo sentido Rodrigo Jesus e Nilma Gomes (2014) argumentam que “ (...) a missão das Constituições Nacionais é estabelecer documentalmente todas as instituições e princípios vigentes em uma determinada época. Nesse sentido, uma Constituição não se resume a um conjunto de regras escritas em um pedaço de papel, mas, se vincula aos elementos reais de poder (...)”.

A década 1990, marcada pela abertura democrática, foi palco de várias manifestações e mobilização dos movimentos sociais negros, que ganharam reforço com o apoio de entidades sindicais e ONG's em reinvindicações antirracistas, como na Marcha Zumbi dos Palmares contra o Racismo, pela Cidadania e a Vida. Em resposta, o governo de Fernando 
Henrique Cardoso criou o Grupo de Trabalho Interministerial de Valorização da População Negra (1995) que ficou responsável por propor ações integradas para combater o racismo, além de recomendar e promover políticas para consolidar a cidadania da população negra brasileira (JACCOUD, 2009).

A partir da década de 1990 os debates sobre ações afirmativas tornaram-se mais frequentes, e os argumentos formulados ao longo desse histórico das ciências sociais brasileiras em termos de relações raciais passaram a ser mobilizados como base dessas discussões. Em 1996, mais especificamente, o Ministério da Justiça convidou pesquisadores brasileiros e americanos e também lideranças do movimento negro para o seminário internacional Multiculturalismo e racismo: o papel da ação afirmativa nos estados democráticos contemporâneos. Pode-se dizer que essa foi uma das primeiras vezes que o governo federal admitia a possibilidade de se pensar em políticas públicas para ascensão do negro no Brasil (GUIMARÃES, 2009).

Importante destacar também, que possivelmente, esse foi um dos primeiros momentos em que intelectuais das ciências sociais, brasileiros e norte-americanos, juntamente com movimento negro brasileiro debatiam em um espaço público de âmbito federal as ações afirmativas. Mais adiante será apresentado um histórico básico das ações afirmativas no Brasil, porém desde já cabe salientar que argumentos formulados nas ciências sociais têm sido frequentemente apropriados e articulados nos debates sobre ações afirmativas, tanto pelo grupo favorável como pelo grupo contrário a essas medidas. Sendo possível notar de modo evidente a influência que as discussões acadêmicas têm nas políticas públicas e na vida dos cidadãos.

\subsection{POLÍTICAS DA RAÇA}

Nas duas partes anteriores deste capítulo buscou-se primeiro delimitar conceitos que serão frequentemente utilizados no trabalho: raça, racismo e racismo institucional. Em segundo lugar pretendeu-se localizar o debate sobre relações raciais nas ciências sociais do país apresentando brevemente alguns dos principais pensadores nacionais sobre a temática. Esta terceira parte do capítulo tem por objetivo identificar as políticas que ao longo da história 
definiram as condições do negro de se inserir ou não socialmente. Como a dissertação se propõe justamente a debater o contexto de formação da Lei de Cotas é necessário e interessante compreender inicialmente o histórico de políticas da raça do país.

Inspirada pela proposta do livro Políticas da raça: experiências e legados da abolição e da pós-emancipação no Brasil (2014), organizado por Flávio Gomes e Petrônio Domingues, acredito que ao se refletir à luz da história das políticas do país será possível compreender de modo mais completo os argumentos e posicionamentos que têm sido utilizados nos debates sobre ações afirmativas atualmente.

\begin{abstract}
"Colocando a experiência histórica brasileira em tela, [demonstra-se] que o legado não resolvido da emancipação é uma parte do tempo presente da nação mesmo após mais de 120 anos do fim da escravidão. O anseio por autodeterminação, reconhecimento, políticas redistributivas, igualdade nas relações sociais, direitos humanos e acesso aos recursos da terra e aos frutos do próprio trabalho ainda continua no horizonte de milhares de brasileiros. "(GOMES; DOMINGUES, 2014, p. 16)
\end{abstract}

Sabe-se que há quem defenda que o Brasil não possui um histórico de leis raciais, e que pela característica de integração social por meio da miscigenação, a inclusão dos negros no país se deu mais pela esfera privada do que pela esfera pública (AVRITZER e GOMES, 2013). Em comparação com os EUA talvez seja possível crer que o Brasil realmente não possui um histórico de leis que delimitam as condições e possibilidades sociais de certos grupos raciais. Nos Estados Unidos, por exemplo, houve o impedimento legal ao casamento entre negros e brancos, o que não se deu no Brasil.

No entanto, o que se nota em terras brasileiras é o absoluto silêncio estatal, no sentido de reparação e inclusão social aos ex-escravos, ou o tratamento das questões raciais exclusivamente pela perspectiva criminal. O silêncio ou o tratamento pela perspectiva criminal demonstram como eram constituídas as políticas para a população negra brasileira.

O quadro 3 é um esforço no sentido de se apresentar algumas das normas que impactaram negativamente a possibilidade de inclusão ou mobilidade social dos negros. Desde a criminalização de práticas culturais como a capoeira ${ }^{18}$, o samba ${ }^{19}$ e as religiões de matriz

\footnotetext{
${ }^{18}$ De 1890 a 1935, a capoeira foi proibida por lei. O código penal da República dos Estados Unidos do Brasil (1890) por meio do decreto 847, do artigo 402 ao artigo 405, define Capoeiragem e a penalização da prática. Mais informações no artigo 'Capoeira, do crime à legalização: Uma história de resistência da cultura popular' (2013), disponível na internet.

${ }^{19}$ Não havia tipificação criminal específica, contudo, os sambistas geralmente eram enquadrados na tipificação vadiagem, principalmente no final do século XIX e início do século XX.
} 
africana $^{20}$, passando pelo tratamento das questões raciais unicamente pelo prisma criminal, apenas no presente século que se observa que o Estado brasileiro inicia a normatização afirmativa das relações raciais. Uma sociedade fundada na desigualdade, como é o caso do Brasil, necessariamente precisará normatizar no sentido da reparação social caso queira garantir a cidadania para todos.

Para tratar desse tema dois estudos são interessantes e oferecem significativas contribuições, são eles: Antirracismo - Coletânea de leis brasileiras Federais, Estaduais e Municipais de Hédio Silva Jr. (1997), que reúne uma série de leis de todos os níveis federativos que tratam sobre negro, afro-brasileiro, raça, cultura negra, igualdade, preconceito, discriminação; e o texto Instrumentos Normativos Federais relacionado ao preconceito e às desigualdades raciais (2011) produzido pelo IPEA, que faz o levantamento das normas federais de 1950 a 2003.

A obra de Hédio Silva Jr. (1997) apresenta um monumental trabalho de compilação das leis antirracistas que existiram, algumas continuam existindo, no Brasil desde a década de 1940. O autor argumenta que há alguns estudiosos que tem se dedicado a estudar relações raciais e direito no país e, entre eles, há um consenso de que "a inscrição do princípio da nãodiscriminação e as reiteradas declarações de igualdade têm sido insuficientes para estancar a reprodução das práticas discriminatórias na sociedade brasileira. Referimo-nos a uma ampla variedade de condutas, via de regra silenciosas e dissimuladas” (SILVA Jr., 1997, p.6).

A publicação do IPEA (2011) aponta para um caminho similar, afirma que entre 1950 e 1988 as legislações atinentes à temática racial são proibitivas, é dizer, se restringem a proibir e penalizar atos de discriminação racial.

\footnotetext{
"Efetivamente, toda a legislação federal correlata ao tema de 1950 até 1988 se resume à proibição da discriminação: decreta-se ser proibido discriminar, considerase a transgressão uma contravenção e dá-se por resolvido o problema. O gráfico a seguir ilustra tal dinâmica, mostrando a produção normativa de cada década dividida segundo a estratégia de combate ao racismo e às desigualdades, se punitiva ou afirmativa." (IPEA, 2011, p.2)
}

\footnotetext{
${ }^{20}$ O código penal de 1890 fixou como prática criminosa o espiritismo e o curandeirismo, fundamentações legais utilizadas para repressão das religiões de matriz africana. Além disso, como sabe-se até hoje essas religiões são as mais afetadas pela intolerância religiosa, e alguns projetos de lei tramitam visando coibir certas práticas tradicionais. Mais informações na dissertação 'Afirmando a alteridade negra e reconhecendo direitos: as religiões de matriz africana e a luta por reconhecimento jurídico’ (2007), disponível na internet,
} 


\section{Figura 2}

Produção normativa federal por década segundo o tipo de estratégia

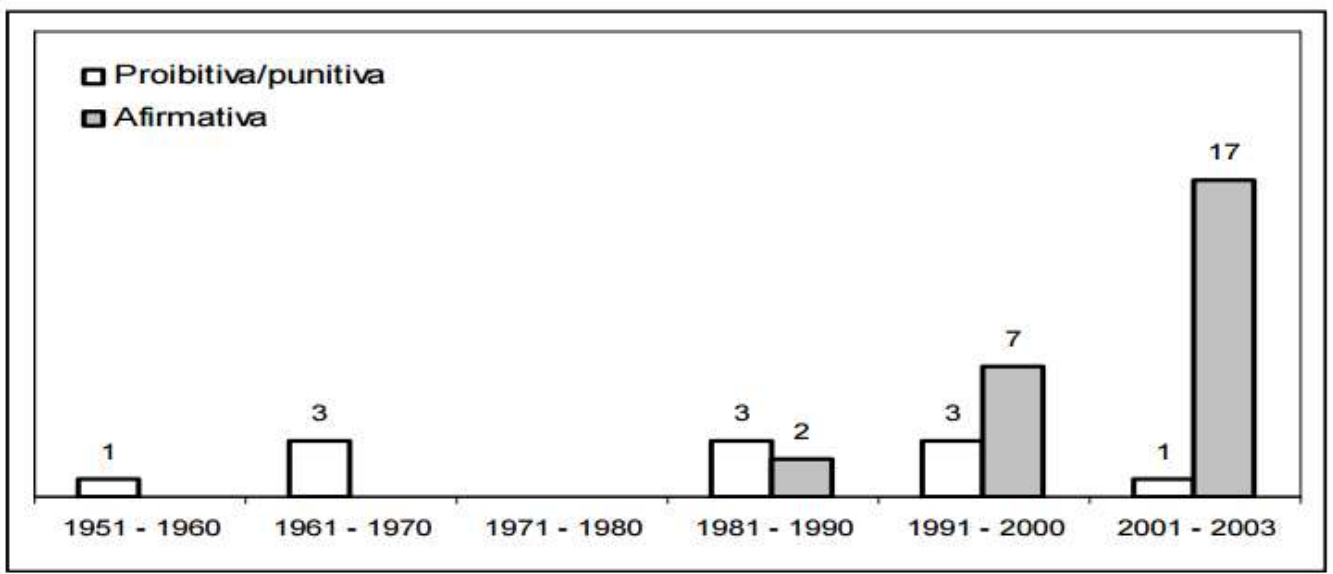

Notas: 1) Na década de 1960, cada convençăo internacional foi aprovada por decreto legislativo e depois promulgada por decreto presidencial. Considerou-se aqui cada convençăo como uma norma, desprezando-se os decretos comelatos. Em outros casos, como a criaçăo da SEPPIR, também se computou uma única norma

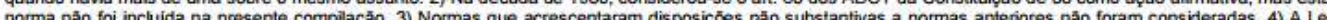
9.474, que trata dos refugiados nâo foi computada.

Fonte: Instrumentos Normativos Federais relacionado ao preconceito e às desigualdades raciais IPEA, 2011.

Como exposto sabe-se que o processo escravagista teve todo amparo legal. A abolição legal da escravatura se deu de modo lento e gradativo; no período colonial e do império predominavam as legislações que legitimavam a hierarquia racial; no início da república as legislações locais continuaram a discriminar as pessoas negras, e por todo país, existiram normas que reprimiam principalmente as manifestações culturais.

A segunda metade desse século foi marcada por leis de criminalização da discriminação racial, também em decorrência das experiências da Segunda Guerra; porém não existiam normas que possibilitassem a efetiva inclusão social da população negra. A constituição federal de 1988 foi um marco muito importante nesse sentido, uma vez que ela não apenas prevê a criminalização do racismo, como garante o reconhecimento das terras dos quilombolas e prevê/constrói as bases para a existência de políticas afirmativas.

Posto isso, vale reforçar mais uma vez que esse trabalho argumenta que a institucionalização do racismo é uma realidade do Estado brasileiro, tal processo possui bases históricas importantes. É dizer, o país tem como um de seus pilares de fundação a desigualdade racial. Com aproximadamente 300 anos de escravidão regulamentada, a abolição da escravatura se deu de modo não inclusivo, sem nenhuma condição de integração social dos ex-escravos, existiram decretos limitando o acesso à educação dos negros, leis fomentando a eugenia e normas incentivando a imigração europeia para ocupar postos de 
trabalho.Após isso, praticamente todo o século XX foi marcado pela negação da desigualdade racial, em que a crença intelectual, política e popular era de que se vivia uma democracia racial. Lenta e gradativamente essas ideias foram, e ainda estão sendo, refutadas. E apenas atualmente no século XXI que o Brasil inicia o processo normativo e político de reparação social.

A seguir está o quadro 3, que busca apresentar como se deu a inclusão da questão racial em legislações do âmbito federal. É uma tentativa de se observar como essa questão tem sido enquadrada nas normas nacionais, e de certo modo consegue-se perceber qual projeto político-social que o Estado brasileiro desenvolveu para o povo negro. Como nota-se, e também já foi exposto, a legislação do país até a constituição de 1988 tendia a abordar a questão racial apenas de modo punitivo. Mas o mais interessante é como esse padrão tem se modificado ao longo dos últimos anos. Após a abertura democrática, nota-se que a normatização sobre questões raciais tem alcançado outros temas, como é o caso da educação que será o enfoque deste trabalho.

Quadro 3 - Legislações relacionadas à raça no âmbito Federal

\begin{tabular}{|l|l|l|}
\hline \multirow{4}{*}{$\begin{array}{l}\text { Período escravagista - Leis } \\
\text { Abolicionistas }\end{array}$} & 1850 & Tipo de norma e no de identificação \\
\cline { 2 - 3 } & 1871 & Lei Eusébio de Queiroz - Lei 581/1850 \\
\cline { 2 - 3 } & 1885 & Lei do sexagenário - Lei 3270/1885 \\
\cline { 2 - 3 } & 1888 & Lei Aurea - Lei 3353/1888 \\
\hline \multirow{2}{*}{$\begin{array}{l}\text { Criminalização de práticas } \\
\text { culturais dos afro-brasileiros, } \\
\text { como a capoeira por exemplo. } \\
\text { Além de serem legislações } \\
\text { baseadas em princípios raciais } \\
\text { como o da eugenia }\end{array}$} & 1890 & $\begin{array}{l}\text { Código Penal dos Estados Unidos do Brasil - } \\
\text { Decreto 847/1890 }\end{array}$ \\
\cline { 2 - 3 } Silenciamento & 1934 & Constituição \\
\hline \multirow{2}{*}{$\begin{array}{l}\text { Questão racial trata apenas pelo } \\
\text { prisma criminal/punitivista }\end{array}$} & 1940 & Código Penal - Lei 2848/1940 \\
\cline { 2 - 3 } & 1967 & Constituição \\
\cline { 2 - 3 } & 1978 & Lei 6.620/1978 \\
\cline { 2 - 3 } & 1983 & Lei de Segurança Nacional - Lei 7170/1983 Federal \\
\hline Marco de virada & 1988 & Constituição \\
\hline
\end{tabular}




\begin{tabular}{|c|c|c|}
\hline \multirow{3}{*}{$\begin{array}{l}\text { Além de considerar a questão } \\
\text { racial na área criminal, passa a } \\
\text { apoiar a valorização cultural }\end{array}$} & 1988 & Lei $7668 / 88$ \\
\hline & 1989 & Lei Caó - Lei 7716/1989 \\
\hline & 1990 & Lei $8081 / 90$ \\
\hline \multirow{14}{*}{$\begin{array}{l}\text { Políticas de Promoção da } \\
\text { Igualdade Racial }\end{array}$} & 1996 & Lei 9394/1996 - LDB \\
\hline & 1996 & Decreto 1904/96 \\
\hline & 2001 & Lei 10.172/2001 - PNE \\
\hline & 2002 & Decreto $4.228 / 2002$ \\
\hline & 2003 & Lei $10.678 / 2003$ \\
\hline & 2003 & Lei $10.639 / 03$ \\
\hline & 2003 & Lei 11.096/2005 - PROUNI \\
\hline & 2008 & Decreto 6.096/2007 - REUNI \\
\hline & 2008 & Lei $11.645 / 2008$ \\
\hline & 2010 & 12.288/2010 - Estatuto da Igualdade Racial \\
\hline & 2012 & 12711/2012 - Cotas nas IES Federais \\
\hline & 2013 & Plano Nacional de Educação \\
\hline & 2014 & 12.990/2014 - Cotas no serviço público \\
\hline & 2015 & Resolução 203 - CNJ \\
\hline
\end{tabular}

As ações estatais foram responsáveis por permitir e viabilizar a exploração da mão de obra escrava. Além disso, houve medidas governamentais que limitaram a inclusão social do negro. De formas variadas os marcadores raciais sempre estiveram presentes delimitando o acesso a direitos no Brasil. Sendo que até a constituição de 1988 a perspectiva jurídica de abordagem das questões raciais, em geral, era criminal; a partir do novo século medidas de inclusão, inicialmente culturais foram sendo incorporadas ao ordenamento jurídico brasileiro.

(...) a consolidação da visão, de cunho racista, de que o progresso do país só se daria com o "branqueamento", suscitou a adoção de medidas e ações governamentais que findaram por desenhar a exclusão, a desigualdade e a pobreza que se reproduzem no país até os dias atuais. (THEODORO, 2008, p.15)

É nítido como no novo século a legislação brasileira incorpora a questão racial de modo mais amplo para combater as desigualdades estruturais, porém é necessário reconhecer como tais ações ainda estão distantes do ideal. Principalmente a área educacional tem sido campo frutífero para implementação de políticas antirracistas, tanto em ações de caráter 
reformista como iniciativas para reestruturação das práticas educacionais. Cabe agora realizar uma breve revisão histórica especificamente sobre a área da educação que será o campo central dessa dissertação.

A abordagem das desigualdades educacionais em decorrência das questões de raça começou a ser pautadas academicamente com mais dados, nas ciências sociais, na década de 1990. Carlos Hasenbalg e Nelson do Valle Silva (1990) no artigo Raça e oportunidades educacionais no Brasil analisam se há desigualdades raciais na apropriação das oportunidades educacionais no país, e a conclusão dos autores informa que:

\begin{abstract}
(...) a proporção de pretos e pardos que não têm acesso algum à escola é três vezes maior do que a dos brancos. Estas desigualdades não podem ser explicadas nem por fatores regionais, nem pelas circunstâncias sócio-econômicas das famílias. Embora uma melhor situação sócio-econômica reduza a proporção de crianças que não têm acesso à escola independentemente de sua cor, ainda persiste uma diferença clara nos níveis gerais de acesso entre crianças brancas e não brancas, mesmo nos níveis mais elevados de renda familiar per capita. (HASENBALG e SILVA, 1990, p.8, grifo теи)
\end{abstract}

A incorporação dessas informações às políticas públicas e a produção legislativa ocorreu mais de uma década depois, em 2003, a partir da Política Nacional de Promoção da Igualdade Racial ${ }^{21}$ (PNPIR). A segunda metade do século XX foi marcada, em termos de legislação educacional e questão racial, pela tímida, quando não inexistente, aparição da temática racial. Embora os discursos de renomados pensadores da educação em prol da escola pública mobilizassem a temática racial, na produção legislativa quase não se nota a aparição da discussão racial. Na educação, conforme afirma Dias (2004), a temática racial enquanto recurso argumentativo estava bastante presente, porém os avanços legislativos no período eram pequenos, mas não insignificantes.

Leis relevantes da área da educação como a LDB/96 e o PNE/2001 abordam pontualmente a temática racial destacando a importância de as práticas educacionais não reforçarem a discriminação e o preconceito. As discussões em torno da construção da Lei de Diretrizes e Bases da Educação Nacional (LDB), sancionada em 1996, ocorreram no mesmo contexto político de dois eventos importantes no histórico de mobilizações raciais: o centenário da Abolição (1988) e os 300 anos da morte de Zumbi (1995). Dias (2004) afirma que as questões raciais colocadas nessa versão da lei foram pontuais, incentivando que o

\footnotetext{
${ }^{21}$ Disponível em: http://bvsms.saude.gov.br/bvs/publicacoes/politica_nacional_promocao_igualdade_racial.pdf
} 
ensino de história do Brasil considerasse as diferentes culturas e etnias, especialmente das matrizes indígena, africana e europeia.

Em 2001, no primeiro Plano Nacional de Educação também se nota que a temática racial está presente, ainda que de forma bastante retraída e pontual. Na parte destinada à discussão do ensino fundamental, entre os objetivos e metas, aparece a meta 11 com a seguinte redação:

11. Manter e consolidar o programa de avaliação do livro didático criado pelo Ministério de Educação, estabelecendo entre seus critérios a adequada abordagem das questões de gênero e etnia e a eliminação de textos discriminatórios ou que reproduzam estereótipos acerca do papel da mulher, do negro e do índio ${ }^{22}$. (PNE, 2001)

Esse texto antecede a lei 10.639/2003 e é possível notar neste trecho a preocupação com os livros didáticos e seu potencial de propagar conteúdos discriminatórios. Note-se, então, que mesmo sendo pontual a citação à temática racial é importante, posto que se preocupa com a reprodução simbólica de conteúdos discriminatórios e preconceituosos em materiais didáticos. Ao se incluir esse aspecto na avaliação dos materiais, medidas contrárias a essa reprodução podem ser tomadas.

O ano de 2003 tem importância diferenciada nessa trajetória de legislações da educação e a questão racial, posto que é promulgada a lei 10.639/2003, que inclui no currículo oficial da rede de ensino a obrigatoriedade da temática 'História e Cultura Afro-brasileira'. Essa lei é um marco importantíssimo e atende a demandas históricas do movimento negro brasileiro uma vez que essa legislação possibilita a formação de um novo imaginário social em que a história e a cultura afro-brasileira são apresentadas com valor positivo, realidade distinta do que se observava até o momento.

Também nesse ano ocorreu a criação da Secretaria Especial de Políticas de Promoção da Igualdade Racial (SEPPIR) e um dos primeiros documentos oficiais produzidos por essa secretaria para induzir políticas públicas foi a Política Nacional de Promoção da Igualdade Racial. Ainda na área da educação, um desdobramento importante da criação da SEPPIR/PR foi a incorporação em 2003 do quesito cor/raça nos formulários de aluno(a) e profissional escolar do Censo Escolar - produzido pelo Instituto de Estudos e Pesquisas Educacionais Anísio Teixeira (INEP/MEC). Conforme documento oficial do órgão de 2013:

\footnotetext{
${ }^{22}$ Disponível em: http://www.planalto.gov.br/ccivil_03/leis/leis_2001/110172.htm
} 
O panorama apresentado demonstra como as populações negra e indígena, apesar dos avanços recentes, ainda enfrentam dificuldades em acessar e permanecer nos diversos espaços educacionais. A desigualdade observada nos indicadores educacionais evidencia como a inclusão do campo cor/raça é capaz de garantir maior detalhamento na análise do perfil educacional dos brasileiros. O quesito permite que políticas voltadas à eliminação de desigualdades históricas entre grupos populacionais possam ser elaboradas, implementadas, monitoradas e avaliadas ${ }^{23}$. (INEP, 2013, p.3 e 4)

Apesar de ser uma demanda histórica do movimento negro e mesmo que seja possível observar alguns avanços nas legislações de 1990 e início de 2000, apenas após a criação da SEPPIR/PR que certas políticas públicas educacionais passaram a incorporar a questão racial em sua formulação. Como se sabe, parte essencial do planejamento de uma política é a apresentação de dados que expressem os problemas e debilidades dos sistemas. No caso da política educacional não é diferente, mesmo sendo possível observar as desigualdades raciais na educação a partir de outras fontes, entende-se como fundamental que os dados oficiais sobre educação e desigualdades produzidos pelo INEP e outros institutos/centros de pesquisa incluam as desigualdades raciais.

As políticas educacionais são cada vez mais pressionadas a aderir ao debate racial. Em 2004, na reestruturação realizada no ministério da educação, foi instituída a Secretaria de Educação Continuada, Alfabetização e Diversidade (SECAD/MEC) que apresentou em seu relatório de gestão ${ }^{24}$ entre as atividades e resultados, algumas ações relacionadas à 'Educação para a diversidade étnico-racial' (item 3.5). Esse documento demonstra que em todos os níveis educacionais (fundamental, médio e superior) iniciativas relacionadas à questão racial foram adotadas. Foram realizados fóruns estaduais que discutiram a aplicação da lei 10.639/2003; ocorreu a promoção do Encontro Nacional 'O negro no ensino médio' (2003); bem como foi dado apoio aos Núcleos de Estudos Afro-brasileiros (NEABs) nas Universidades e incentivo a formulação de propostas de implementação de políticas educacionais afirmativas.

Em 2004 foi criado pelo governo federal o Programa Universidade para Todos (Prouni) programa que amplia o acesso ao ensino superior, buscando reduzir desigualdades de oportunidades que perduram na sociedade brasileira. Ao que tudo indica esse programa foi, também, um dos balizadores da política de cotas para as universidades federais, uma vez que

\footnotetext{
${ }^{23}$ Disponível em: http://download.inep.gov.br/educacao_basica/educacenso/documentos/2015/cor_raca.pdf ${ }^{24}$ Disponível em: http://portal.mec.gov.br/index.php?option=com_docman\&view=download\&alias=18641 secadi-relatorio-gestao-mec-2004-pdf\&Itemid=30192
} 
o seu modelo de concessão de bolsas se assemelha muito às vagas reservadas na Lei de Cotas (Lei nº 12.711/2012). Conforme explica a socióloga Márcia Lima (2015):

\begin{abstract}
O Programa [PROUNI] tem como finalidade a concessão de bolsas de estudos integrais e parciais $(50 \%)$ a estudantes de baixa renda em cursos de graduação de instituições privadas de educação superior. O ProUni também reserva bolsas para que os que se autodeclaram pretos, pardos ou índios no ato de inscrição. $O$ percentual de bolsas destinadas aos cotistas é estabelecido com base no número de cidadãos pretos, pardos e indígenas, por Unidade da Federação, segundo o último censo do IBGE, devendo se enquadrar nos demais critérios de seleção do programa: renda familiar per capta de três salários mínimos, ter feito o ensino médio na escola pública e ter realizado a prova do Exame Nacional do Ensino Médio (ENEM). (LIMA, 2015 p. 39)
\end{abstract}

Como nota-se a partir de 2005, há uma política de inclusão étnico-racial no ensino superior, ainda que o critério racial esteja condicionado ao critério de renda. Assim como explica Lima (2015), dados do INEP indicam que no sistema de ensino superior 89,5\% são instituições privadas de ensino, o que significa que pouco mais de $10 \%$ das instituições são públicas. Como o maior número de vagas no ensino superior está no setor privado é relevante e necessário que o estado estimule a inclusão social e étnico-racial nessas instituições. Contudo, algumas críticas também têm sido levantadas, entre elas, o investimento indireto de recursos públicos na educação privada (com a isenção de impostos), a pouca oferta de carreiras de prestígio e de maior retorno no mercado de trabalho nas instituições privadas bem como alguns problemas com a qualidade do ensino ofertado nas instituições particulares. Lima (2015) argumenta que o programa propõe a inclusão, porém reproduz algumas desigualdades e reforça a estratificação no nível superior.

Nesse período inicia-se de modo gradual e crescente a implementação de ações afirmativas nas universidades brasileiras, e no âmbito federal, em 2012, é aprovada a Lei de Cotas (Lei $n^{\circ}$ 12.711/2012). Importante notar como a legislação federal sobre cotas se insere em um contexto mais amplo de discussões e de desenvolvimento de políticas, em que as questões raciais vão sendo paulatinamente colocadas com mais importância nos debates da área da educação.

Em 2014 foi aprovado o novo Plano Nacional de Educação (Lei 13.005/2014), e assim como supramencionado a questão racial apresenta-se de modo distinto nessa legislação. A estratégia 7.34 que busca a promoção de uma política de preservação da memória nacional, de acordo com Lima (2015), consolida a urgência da implementação da história e cultura dos afro-brasileiros para que os negros estejam na memória nacional como agentes da história; a estratégia 7.25 prevê a efetiva implementação das leis que visam garantir os conteúdos sobre 
história e cultura afro-brasileiras e indígenas (Lei 10.639/2003 e Lei 11.645/2008); e destaque-se a meta 8 , que trata da escolaridade média da população brasileira e prevê:

Elevar a escolaridade média da população de 18 a 29 anos, de modo a alcançar no mínimo 12 anos de estudo no último ano de vigência deste Plano, para as populações do campo, da região de menor escolaridade no País e dos $25 \%$ mais pobres, e igualar a escolaridade média entre negros e não negros declarados ao IBGE. (PNE, 2014)

Logo, observa-se que o combate às desigualdades raciais na educação é incorporado pelo Plano Nacional de Educação, e por isso pode-se dizer que há uma meta nacional de elevar a escolaridade média da população, com enfoque na população negra. Portanto, é nítido como a legislação mais recente da área da educação engloba a temática racial de modo a buscar minimizar desigualdades denunciadas há décadas por organizações negras e, no início da década de 1990, por acadêmicos. Com a positivação desse déficit em meta no Plano Nacional de Educação espera-se que existam ações governamentais mais especificas e eficientes no combate a tais desigualdades.

\subsection{MOVIMENTO NEGRO E EDUCAÇÃO ANTIRRACISTA}

Denunciar é prática recorrente do movimento negro quando se trata de escolarização da população negra, isso por que desde a abolição da escravatura é notável como o Estado brasileiro relegou as pessoas negras à exclusão, ao abandono e à marginalidade social. Como bem expõem Gonçalves e Silva (2000), no final do século XIX, a presença de escravos e de negros libertos e livres em estabelecimentos de ensino era vetada em muitos estados da nação.

A lei 2040/1871, lei do ventre livre, expõe uma das faces da tensão racial que existia no país à época, ou seja, no período de seu trâmite havia a proposta de que os senhores de escravos fossem responsáveis pela instrução das crianças negras, contudo apresenta-se na lei a isenção de "qualquer responsabilidade quanto à instrução das crianças nascidas livres de mulheres escravas" (FONSECA, 2000, p. 40), o que demonstra o descompromisso do poder público brasileiro com a população negra.

Gonçalves e Silva (2000) levantam a hipótese de que houve, na segunda metade do século XIX, uma iniciativa que poderia ter mudado a condição educacional dos negros que 
ingressariam no século XX. Contudo, o Estado assistiu passivamente à precarização educacional dessa parcela da população. Os autores argumentam que homens e mulheres negras eram afastados dos estudos pela necessidade de trabalhar para subsistência. É dizer, tanto homens quanto mulheres precisavam se inserir no mercado de trabalho; sendo que para as mulheres cabia os serviços domésticos, e para os homens, com mais dificuldade de inserção, as atividades braçais e menos qualificadas.

Sabe-se que historicamente é uma questão central para o movimento negro tratar sobre reivindicações de acesso à educação. Como exposto no trecho abaixo:

\begin{abstract}
Nos jornais da imprensa negra paulista do começo do século, no período fecundo de sua divulgação, que vai dos anos 20 ao final dos anos 30, encontram-se artigos que incentivam o estudo, salientam a importância de instrumentar-se para o trabalho, divulgam escolas ligadas a entidades negras, dando-se destaque àquelas mantidas por professores negros. Encontram-se mensagens contendo exortações aos pais para que encaminhem seus filhos à escola e aos adultos para que completem ou iniciem cursos, sobretudo os de alfabetização. O saber ler e escrever é visto como condição para ascensão social, ou seja, para encontrar uma situação econômica estável e, ainda, para ler e interpretar leis e assim poder fazer valer seus direitos." (GONÇALVES e SILVA, 2000, p. 140)
\end{abstract}

Na década de 1920 havia entre os militantes e intelectuais negros a consciência de que os estabelecimentos oficiais de ensino não formariam os estudantes negros com a integralidade necessária, é dizer, estudos sobre as tradições africanas, por exemplo, estavam fora da formação oficial oferecida. Com vistas a incentivar as pessoas negras a passar por um processo de formação mais completo a Frente Negra Brasileira, na década de 1930, formulou uma proposta de educação política ousada, uma instituição de ensino que pretendia instalar-se por todo o Estado de São Paulo oferecendo ensino primário, secundário, comercial e ginasial. Um projeto chamado "Liceu Palmares", não exclusivo para negros, mas prioritariamente para eles. O curso de alfabetização desse projeto atendeu a cerca de 4000 alunos, contudo a iniciativa não teve longa duração por falta de recursos (GONÇALVES e SILVA, 2000).

É essencial destacar que já nesse período as lideranças do movimento negro possuíam o entendimento da importância de uma formação política, para além da escolarização. Sabese, também, que a reação negra à precarização educacional exigia dos militantes engajamento pessoal e compromisso com a causa. Gonçalves e Silva (2000) informam que o jornal $O$ Clarim d'Alvorada (1929) em convite para um evento expõe sua preocupação com a questão educacional, evidenciando a convicção de que não era possível esperar muito do Estado brasileiro: 


\begin{abstract}
"Em quarenta anos de liberdade, além do grande desamparo que foi dado aos nossos maiores, temos de revelar com paciência, a negação de certos direitos que nos assistem, como legítimos filhos da grande pátria do cruzeiro. Se os conspícuos patriotas desta República não cuidaram da educação do negro, nosso congresso tratará desse máximo problema que está latente na questão nacional." (apud. Clarim d'Alvorada, 07/04/1929, p. 1).
\end{abstract}

Note-se que a busca pela emancipação do povo negro está colocada nesse trecho, bem como é característica o pensamento autônomo sobre educação. Nas décadas seguintes ampliaram-se as demandas, além das reinvindicações por acesso ao ensino fundamental, também se reivindica pelo ensino médio e universitário. O Teatro Experimental do Negro (TEN), importante organização cultural e social do período, possuía como uma de suas pautas a questão educacional. A aproximação gradual entre o mundo acadêmico e a militância passou a ocorrer de modo mais nítido nesse período, e em parceria com Abdias do Nascimento, o sociólogo Guerreiro Ramos contribuiu para formulação do entendimento de que a questão racial é uma problemática nacional.

Nos anos de 1940 e 1950 apresentavam-se como reivindicações além do ensino fundamental gratuito para todos, que fossem concedidos subsídios para negros no ensino secundário e universitário. De forma inovadora o TEN associa educação à cultura, formulando um mecanismo não apenas de formação educacional, mas também trabalhando por meio da arte com questões psicoterapêuticas. A valorização das origens africanas, a exaltação das raízes culturais e autoestima das pessoas negras eram trabalhadas de modo complementar à formação educacional.

Vale destacar, também, que esse é um momento de mudança em que a educação passa a ser notada como um direito e uma obrigação do Estado. Evidentemente que as organizações negras não se isentavam do trabalho de proporcionar espaços alternativos e complementares de formação. Porém, a partir desse período passa-se a compreender a educação como um direito fundamental que deve ser oferecido pelo Estado.

Apesar da ditadura militar, a década de 1970 caracteriza-se pela rearticulação do movimento negro nacionalmente. Especificamente o ano de 1978 foi marcado pelo primeiro ato público do Movimento Negro Unificado em São Paulo. E a partir deste momento a questão educacional ganha mais relevância para as organizações negras. 
Na década de 1980, o Programa de Ação da Convenção do Movimento Negro Unificado (Belo Horizonte, 1982) apresentava como estratégias de luta no combate ao racismo, pontos como: modificações nos currículos, com objetivo de eliminar os estereótipos vinculados aos negros e à cultura afro-brasileira; a ampliação do acesso de negros para todos os níveis educacionais; e a criação de bolsas e condições de permanência dos jovens no sistema de ensino (GONÇALVES e SILVA, 2000).

Poucos anos depois, em 1984 e 1985, no Rio Grande do Sul, foram realizados o I e o II Encontros Nacionais sobre a realidade do negro na educação. Tais eventos tinham entre seus temas, por exemplo, a construção positiva da identidade negra e a autoestima de crianças e jovens negros. Esses eventos tiveram repercussão política, sendo que inclusive há relatos de uma secretaria municipal de educação que passou a incorporar a história do negro em suas escolas. Em todo o país, eventos e debates foram realizados sobre a temática da educação e das relações raciais. Destaca-se a partir desse período um entendimento alargado das demandas, que não se restringiam mais ao acesso, porém tratavam também do controle social (GONÇALVES e SILVA, 2000).

O movimento, contemporâneo, de mulheres negras que nasce neste período, passa a entender o campo da educação como uma arena promissora para emancipação social negra. E nesse sentido, inicia-se a compreensão sobre a importância do controle social nas escolas, já os estabelecimentos educacionais desempenham papel de propagadores da supremacia racial branca. Nesse sentido, a democratização do ensino torna-se o centro, e vários aspectos passam a ser alvo de reivindicações, como por exemplo: o livro didático, a formação dos professores e o currículo.

Com a abertura democrática do Estado brasileiro, a década de 1990 caracteriza-se pela intensificação da relação entre os movimentos negros e a administração pública. Iniciativas em diferentes localidades do país são tomadas para que as demandas desses movimentos fossem sendo gradativamente atendidas. A articulação entre o movimento negro, a academia e as secretarias de educação foram essenciais para que fosse possível dar mais esse passo.

Em 1995, ocorreu em Brasília, um dos maiores eventos contemporâneos relacionados à temática racial - a Marcha Zumbi dos Palmares, que reuniu cerca de trinta mil pessoas. $\mathrm{O}$ documento oficial dessa Marcha dedica-se em uma parte exclusivamente a tratar de racismo e educação. Sendo que há duras críticas ao modelo educacional do Brasil que, segundo o 
documento, caracteriza-se por atentar à dignidade humana. A página 11 do documento apresenta as escolas brasileiras como espaços privilegiados de aprendizado do racismo.

No início do século XXI com adesão de instituições de ensino superior às cotas raciais, acirram-se os debates e os ânimos sobre a importância da educação para emancipação do povo negro. A promulgação da lei 10.639/2003, a criação do Prouni (Lei 11.096/2005) em 2005, a implementação de cotas em várias universidades pelo país fez os debates sobre educação e a questão racial serem elevados a outro patamar.

No plano acadêmico um marco importante nesse processo de mobilização do movimento negro dentro das Instituições de Ensino Superior foi a criação da Associação Brasileira de Pesquisadores Negros (ABPN), em 2000, que surge com o objetivo de “congregar pesquisadores negros e não negros que estudam relações raciais e demais temas de interesse da população negra, produzir conhecimento científico sobre a temática racial e construir academicamente um lugar de reconhecimento das experiências sociais do movimento negro como conhecimentos válidos." (GOMES, 2012, p.740)

Em 2007, ocorreu na Bahia, o Encontro Nacional da Juventude Negra que em seu relatório final ${ }^{25}$ apresenta um eixo específico de propostas para reparações e ações afirmativas. Entre outras reivindicações ao poder público estão: 1) Estabelecer sistemas de acesso e permanência aos jovens negros (as) e indígenas desde o ensino fundamental e médio até a Universidade (graduação e pós-graduação) e ao serviço público e privado, adotando o programa de ações afirmativas; 2) Garantia do percentual proporcional ao número de negros (as) nos seus estados, nos processos seletivos de admissão aos cursos de graduação e pósgraduação, nas instituições estaduais e federais de ensino superior; e 3) Incentivar a criação de frentes parlamentares pró ações afirmativas em todos os municípios e estados brasileiros. Como nota-se, a temática da educação e das ações afirmativas estava em debate nos encontros da juventude negra, bem como propostas políticas viáveis têm sido apresentadas pela sociedade civil negra.

Em 2012, foi sancionada a Lei de Cotas, e apesar do formato dessa legislação não ser de caráter exclusivamente racial, talvez esse tenha sido o modelo possível para que fossem acomodadas as tensões e conflitos políticos que estiveram presente no seu contexto.

\footnotetext{
${ }^{25}$ Disponível em: http://www.institutobuzios.org.br/documentos/I\%20ENJUNE_RESOLU\%C3\%87\%C3\%95ES.pdf
} 
Sabe-se que por mais avanços que hajam ocorrido nos últimos anos, os resultados e benefícios alcançados ainda são insuficientes. De modo que as manifestações de coletividades negras continuam pautando a temática educacional. Exemplo disso foi a Marcha das Mulheres Negras, realizada em 2015, em Brasília, que apresenta em sua Carta a questão do direito à educação.

Entre as demandas, destacam-se como centrais três ideias: 1) Efetivação e ampliação de políticas públicas de permanência dos alunos que ingressam no ensino superior por cotas ou outras políticas inclusivas; 2) Aprimoramento dos currículos escolares, formação continuada dos professores e elaboração de material didático; 3) Fortalecimento de políticas para redução da evasão escolar e da defasagem idade-série dos alunos de grupos étnico-raciais discriminados. Percebe-se que todas essas demandas são desdobramentos, reflexões amadurecidas de discussões e lutas anteriores.

Essa parte do capítulo buscou apresentar a educação como uma pauta histórica e frequente entre as demandas do movimento negro. Dentre as mobilizações antirracistas, e também, nas discussões propostas pelas organizações negras a temática educacional sempre esteve presente. Sendo, portanto, que nenhum dos avanços recentes na área educacional podem ser interpretados como benesses do Estado brasileiro, mas sim como resultado decorrente de décadas de luta, mobilização e tensionamento da pauta pública em favor da efetiva inclusão social e emancipação dos negros.

\subsection{AÇÕES AFIRMATIVAS NO BRASIL}

O tema central dessa dissertação - a Lei 12.711/2012 - nos conduz a desenvolver uma breve discussão sobre ações afirmativas. A seguir apresentam-se algumas definições de ações afirmativas, suas finalidades, um breve histórico da discussão no Brasil e, por fim, a proposta deste trabalho.

Algumas definições do termo ações afirmativas contribuem para que seja possível compreender seu propósito e suas aplicações no Brasil. Como é notável, vários intelectuais brasileiros têm se dedicado a investigar o tema e a produzir dados e informações sobre as políticas de ações afirmativas no Brasil. Existem alguns grupos de pesquisa sobre a temática no país, como por exemplo, o Grupo de Estudos Multidisciplinares da Ação Afirmativa (GEMAA/UERJ); o Grupo Estratégico de Análise da Educação Superior no Brasil (GEA/FLACSO); e a Rede Ação Afirmativa (vinculado ao centro de estudos afro-orientais da 
UFBA). Outras importantes pesquisas têm sido desenvolvidas autonomamente por estudiosos de todo país.

De acordo com Silvério (2002) há uma noção mais antiga de ação afirmativa que segue o sentido de reparação de uma injustiça passada; já a noção mais moderna refere-se a um programa de políticas públicas ordenado pelo executivo e legislativo, ou implementado por empresas privadas para possibilitar a ascensão de minorias étnicas, raciais e sexuais.

Joaze Bernardino Costa (2002), parece concordar com a definição exposta anteriormente, e apresenta o conceito de ações afirmativas da seguinte forma:

Ações afirmativas são entendidas como políticas públicas que pretendem corrigir desigualdades socioeconômicas procedentes de discriminação, atual ou histórica, sofrida por algum grupo de pessoas. Para tanto, concedem-se vantagens competitivas para membros de certos grupos que vivenciam uma situação de inferioridade a fim de que, num futuro estipulado, esta situação seja revertida. Assim, as políticas de ação afirmativa buscam, por meio de um tratamento temporariamente diferenciado, promover a equidade entre os grupos que compõem a sociedade. (COSTA, 2002, p. 256)

Em outras palavras e de modo complementar, é importante apresentar também a definição dada por João Feres Jr. (2015) sobre o tema:

(...) como política de caráter focal que visa à justiça social, a ação afirmativa procura romper com mecanismos inerciais de exclusão que permanecem intocados pelas políticas públicas universais ou quando estas sequer são plenamente implantadas. (...) Políticas de ação afirmativa podem ser definidas como provisões de alguma espécie de reparação para determinados grupos persistentemente discriminados e vítimas de exclusão socioeconômica. Em grande parte dos casos, para além do atendimento as reivindicações coletivas como distribuição de terras, de moradias, recursos escassos e proteção a certos estilos de vida, elas consistem em proporcionar vantagens competitivas para membros de grupos desprivilegiados em processos de disputa acirrada por posições sociais de prestígio. Essa última modalidade de ação afirmativa tem como objetivo mitigar a sub-representação dessas pessoas nos estratos médios e altos de sociedades que historicamente as marginalizaram e dificultaram sua ascensão social. (FERES Jr., 2015, p.96)

Colocadas algumas definições que serão articuladas para se pensar este trabalho é interessante, também, apresentar breve histórico desse conceito. A expressão ação afirmativa, conforme utilizada no Brasil, tem como principal referencial os Estados Unidos, embora tenham existido políticas similares anteriormente em outros países. Em meados da década de 1960, período de ampliação da luta de movimentos anti-racistas e de fortalecimento das reivindicações por direitos civis para os negros naquele país, iniciou-se o debate dessas propostas. Os movimentos sociais desse período nos EUA começaram a pautar o estado no sentido de que não eram suficientes as leis que proibiam a segregação racial, mas também era importante o desenvolvimento de uma postura ativa na melhoria das condições de vida da população negra. 
Os norte-americanos são referência no debate e na implementação de políticas de ações afirmativas, porém a prática se difundiu por muitos outros países do globo, sendo que há casos dessas políticas na Europa, Ásia, África e também em outros países Sul-americanos. Cada localidade fez as adaptações necessárias a seus contextos, sendo que o formato das políticas variou e varia muito nos diferentes países. Há locais em que elas são obrigatórias, outros em que elas são voluntárias, bem como há lugares que formularam políticas híbridas. Há locais onde sua implementação se deu por meio de programas governamentais, em outros o foco foi dado na iniciativa privada. Também se nota a variação do público conforme a região, mas os principais beneficiários dessas políticas têm sido as minorias étnicas, raciais e as mulheres (MOEHLECKE, 2002).

A aplicação principal das ações afirmativas concentra-se nas áreas da educação e do mercado de trabalho. Em se tratando de mercado de trabalho as possibilidades de medidas são, entre outras, a garantia de um percentual de capacitação para a parcela beneficiária, mais qualificação e também promoção na carreira. No âmbito educacional as práticas mais comuns são: garantia de um percentual de vagas nos processos seletivos e auxílio permanência para os beneficiários. Portanto, as ações afirmativas têm como objetivo central incluir em espaços de privilégio e poder alguns grupos que teriam o acesso a esses lugares total ou parcialmente negados.

Apresentadas algumas características das políticas de ações afirmativas, é preciso destacar a sua finalidade. As desigualdades sociais combatidas pela ação afirmativa originamse, normalmente, de práticas sistemáticas de algum tipo de discriminação negativa. Essa foi a primeira justificativa que possibilitou tratar diferenciadamente um grupo social (MOEHLECKE, 2002). A sua finalidade última é a redução substantiva ou eliminação das desigualdades sociais relacionadas com a divisão do poder e da riqueza (GOMES, 2001; MENEZES, 2001).

Sabe-se que há mais de duas décadas o debate sobre ações afirmativas é feito no Brasil e algumas das ideias basilares para o debate no contexto nacional foram: 1) O combate sistemático à discriminação existente em certos espaços; 2) A redução de desigualdades que acometem certos grupos vulneráveis; 3) A busca de integração de distintos grupos sociais por meio da valorização da diversidade cultural. Essa última ideia se relaciona à valorização das identidades de grupos segregados, e supõe que a interação mais próxima de pessoas com 
origens diferentes pode prevenir visões e práticas preconceituosas e discriminatórias, que são socialmente indesejáveis (MOEHLECKE, 2002).

A questão do mérito individual também é bastante discutida como um valor importante dado o contexto em que vivemos. Sabe-se que para ser beneficiário de ações afirmativas não basta que o indivíduo pertença a um grupo discriminado, é necessário que ele possua determinadas qualificações. Não é suficiente ser parte de um grupo minoritário para se beneficiar das ações afirmativas, é necessário que sejam demonstradas as capacidades técnicas de trabalho ou que se tenha a qualificação necessária para ingresso no ensino superior, por exemplo.

No Brasil o registro mais antigo que se relaciona a discussão de ações afirmativas é de 1968, quando técnicos do Ministério do Trabalho e do Tribunal Superior do Trabalho apresentaram posicionamento favorável à criação de uma lei que obrigasse empresas privadas a manter uma porcentagem mínima de empregados de cor como a solução possível para o problema da discriminação racial no mercado de trabalho. Porém essa lei nem chegou a ser elaborada (SANTOS, 1999).

Vale destacar que as ações afirmativas, enquanto alternativa política, estavam postas desde 1983 quando Abdias do Nascimento, como Deputado Federal, apresentou o projeto de lei 1332/1983 ${ }^{26}$ que propunha “(...) ação compensatória visando a implementação do princípio da isonomia social do negro, em relação aos demais elementos étnicos da população brasileira (...)".

A proposta de Abdias do Nascimento apresenta entre as ações, por exemplo: a reserva de $20 \%$ de vagas para mulheres negras e $20 \%$ para homens negros na seleção de candidatos ao serviço público; bolsas de estudo; incentivo à empresas privadas que implementassem ações contra a prática de discriminação racial; a inclusão da imagem positiva da família afrobrasileira no sistema de ensino e na literatura didática e para-didática. Essa proposição não obteve sucesso em seu trâmite legislativo, porém notam-se repercussões dessas ideias até os dias de hoje.

Além do âmbito político, nesse mesmo período o mundo acadêmico é marcado pelo surgimento de sistematizações das desigualdades raciais e pela propositura de alternativas

\footnotetext{
${ }^{26}$ Versão digital do projeto de lei disponível em: http://www.camara.gov.br/proposicoesWeb/fichadetramitacao?idProposicao=190742
} 
para efetiva diminuição das desigualdades entre brancos e negros. Nota-se no livro Relações raciais no Brasil (1992) de Carlos Hasenbalg e Nelson do Valle Silva que os estudos realizados sobre as desigualdades raciais apontavam para a possibilidade de intervenção em distorções sociais. Algumas das propostas apresentadas pelos autores são: 1) utilizar a legislação que pune o racismo como crime; 2) aplicar ações afirmativas visando à igualdade, também nesse trabalho, os autores apresentam como obstáculos à implementação a ausência de apoio político e o sistema de classificação racial brasileiro (dificuldade na identificação de quem é branco ou negro); 3) implementar políticas de caráter redistributivo, que não são racialmente específicas, mas auxiliam no combate à pobreza e suas raízes (SILVÉRIO, 2002).

A Marcha Zumbi dos Palmares, em 1995, pressionou o poder público no sentido de desenvolver políticas públicas para a superação do racismo. O presidente da república no período, Fernando Henrique Cardoso, instituiu por decreto a criação de um Grupo de Trabalho Interministerial, para formular políticas de valorização e promoção da população negra. Tal inciativa é simbolicamente representativa na medida em que foi a primeira vez que o movimento negro via suas demandas, de certo modo, incorporadas na institucionalidade do governo federal.

Esse Grupo de Trabalho teve seu papel como precursor em dar estímulo para que as discussões e propostas de ações afirmativas fossem realizadas nas diversas unidades federativas no país. No ano seguinte, em 1996, foi lançado o Programa Nacional de Direitos Humanos que estabelecia, dentre outros pontos, que fossem desenvolvidas ações afirmativas para o acesso de negros a cursos profissionalizantes, à universidade e às áreas de tecnologia de ponta, políticas compensatórias que promovam social e economicamente a população negra.

Nesse mesmo ano, o IPEA e alguns Ministérios do executivo federal promoveram eventos para debater sobre ações afirmativas. A década de 1990 também foi significativa em termos de projetos de lei sobre o tema em trâmite no Congresso Nacional. De acordo com Moehlecke (2002), nesse período tanto no Senado, como na Câmara dos Deputados tramitavam quase uma dezena de projetos sobre ações afirmativas para negros. Entre as propostas desses projetos estavam: a concessão de bolsas de estudo; uma política de reparação, que previa o pagamento de indenização aos descendentes de escravos e, também, que o governo viabilizasse a presença proporcional dessa parcela populacional em todos os 
níveis escolares; além do estabelecimento de um Fundo Nacional para o desenvolvimento de Ações Afirmativas; e a alteração das seleções para garantir o ingresso de negros ao ensino superior.

Em 2001, o Rio de Janeiro por meio de lei estadual estabeleceu que 50\% das vagas dos cursos de graduação das universidades estaduais deveriam ser destinados a alunos oriundos de escolas públicas; sendo que em 2002, uma lei complementar a primeira determinou que $40 \%$ das vagas fossem destinadas à candidatos negros. Outros estados do Brasil, também passaram a implementar ações afirmativas para negros e indígenas para o ingresso no ensino superior, como foi o caso do Paraná, do Mato Grosso do Sul e da Bahia. Nota-se que universidades autonomamente começaram a discutir e formular seus sistemas de cotas com o objetivo de incluir mais negros em seus cursos.

O ano de 2001 foi um marco histórico para as discussões sobre antirracismo no Brasil, por ocasião da Conferência de Durban. A Conferência Mundial contra o racismo, discriminação racial, xenofobia e intolerâncias correlatas da ONU realizada na África do Sul, contou com uma participação muito ativa do Brasil, que levou ao evento não apenas diplomatas, mas também acadêmicos e representantes de movimentos sociais para debaterem relações raciais e estratégias de enfrentamento ao racismo. No relatório conclusivo do evento a adoção de ações afirmativas é apontada como uma necessidade para inclusão social de negros em países como o Brasil, por exemplo.

Com a chegada ao poder do Partido dos Trabalhadores, em 2003, ocorreram algumas modificações na estrutura organizacional do Executivo Federal, entre elas a criação da Secretaria Especial de Promoção de Políticas de Igualdade Racial (SEPPIR/PR) diretamente vinculada à Presidência da República. A instituição da SEPPIR/PR não pode ser tomada como um fato ao acaso, mas representou mais um passo no sentido de se institucionalizar demandas antigas do movimento negro brasileiro como o acesso à educação e redução das desigualdades no mercado de trabalho, necessidades que podem ser trabalhadas com a implementação de ações afirmativas.

Desse modo, pode-se afirmar que a criação da Secretaria alavancou o debate já existente no país sobre ações afirmativas. Além disso, vários estudos técnicos foram realizados a partir dessa instituição que deram base para a formulação de leis federais. Assim como expõe Matilde Ribeiro (2014) em seu livro Políticas de Promoção da Igualdade Racial, 
a pauta das ações afirmativa sempre esteve muito relacionada à criação da SEPPIR e, no foco, do planejamento das políticas públicas pensadas para os negros.

Entre 2001 e 2012, desde quando as primeiras universidades começaram a aderir às ações afirmativas até quando a lei de cotas passa a vigorar para as instituições federais de ensino superior, é possível observar um processo contínuo e crescente de adesão às cotas pelas universidades públicas brasileiras. Além da Lei de Cotas, outro marco muito importante nesse percurso de adesão às cotas foi a decisão do STF na ADPF 186 pela constitucionalidade das cotas étnico raciais. Conforme afirma Lima (2015):

\footnotetext{
Vale enfatizar que mesmo com o reconhecimento da constitucionalidade do uso do critério racial, o governo federal não tinha até então tornado obrigatória a implementação de políticas de ações afirmativas. A decisão da adoção destas políticas, até aquele momento, era realizada de duas formas: 1) Os Conselhos Universitários, cuja autonomia é garantida pela Lei de Diretrizes e Bases da Educação, decidem por sua adoção; e 2) Por meio de lei estadual, aprovada na Assembleia Legislativas dos Estados. (LIMA, 2015, p.27)
}

A formulação e implementação das Ações Afirmativas se deram em meio a uma série de conflitos e divergências. A mídia, a academia, os políticos, os servidores públicos, os profissionais da educação e a sociedade como um todo se engajaram nas discussões sobre o tema. O trecho abaixo relata os embates do mundo acadêmico e a partir dele é possível ter uma ideia da dimensão da polarização que a temática provocou no país.

Foram publicados quatro documentos nomeados de "Manifesto dos Intelectuais"
(2004-2006) pró e contra as políticas racializadas no ensino superior brasileiro. Os
quatro documentos, publicados online, eram convergentes no que diz respeito à
necessidade de reformas no ensino básico para que se obtivesse qualidade. E, eram
divergentes quanto à racialização das políticas sociais e, consequentemente da
sociedade brasileira. Para uns o resultado seria a justiça social e consequentemente a
ampliação de oportunidades e para outros significaria a fragmentação do povo e a
instauração de conflitos raciais onde nunca houve. (GOLÇAVES e PEREIRA,
2013)

Esse tipo de divergência encontra-se também no contexto de formação da Lei de Cotas. E essa proposta de pesquisa pretende justamente ser capaz de descrever e analisar essa trajetória; os acordos, as distorções e as controvérsias geradas pela formação dessa lei podem informar também sobre as disputas que estão colocadas sobre relações raciais no Brasil contemporâneo. O novo contexto exige a atualização do debate para que seja possível construir caminhos sólidos no combate às desigualdades raciais. 


\subsection{A PROPOSTA DE PESQUISA}

O ano de 2012 além de haver sido o ano de aprovação da legislação que trata das ações afirmativas no ensino superior brasileiro, também foi importante para o tema, por que o Supremo Tribunal Federal votou pela constitucionalidade das cotas tal como implementadas pela Universidade de Brasília. A argumentação conclusiva do Ministro Lewandowski aponta alguns dos aspectos debatidos pela Suprema Corte brasileira:

\footnotetext{
(...) considerando, em especial, que as políticas de ação afirmativa adotadas pela Universidade de Brasília (i) têm como objetivo estabelecer um ambiente acadêmico plural e diversificado, superando distorções sociais historicamente consolidadas, (ii) revelam proporcionalidade e a razoabilidade no concernente aos meios empregados e aos fins perseguidos, (iii) são transitórias e prevêem a revisão periódica de seus resultados, e (iv) empregam métodos seletivos eficazes e compatíveis com o princípio da dignidade humana. (LEWANDOWSKI, 2012)
}

Este trabalho buscará observar quais foram os atores, quais foram as argumentações mobilizadas ao longo do processo, além de se considerar aqui como se deram os conflitos e os acordos. Inúmeros argumentos favoráveis e contrários foram levantados, e é certo que as discussões não chegaram a formular um acordo e uma concordância majoritária sobre as cotas para ingresso no ensino superior no Brasil. Contudo, observa-se atualmente certa convergência dos esforços estatais no sentido de aderir às ações afirmativas como medidas necessárias. A existência da Lei de Cotas (Lei n 12.711/2012) e da Lei no 12.990/2014, que versa sobre cotas nas seleções para o serviço ou emprego público são exemplos disso.

Tais fatos chamam a atenção para um novo momento da discussão sobre ações afirmativas. Ou seja, se durante décadas discutiu-se educação e relações raciais, se nos últimos 30 anos iniciou-se um debate mais focado na possibilidade de adesão às ações afirmativas e se na última década notou-se um aumento gradativo de sistemas de cotas para ingresso nas Universidades públicas brasileiras; recentemente nota-se um esforço de organização sistemática das cotas para acesso ao ensino superior ou a cargos e empregos públicos no país. Desde 2012 é possível observar práticas institucionais do Estado brasileiro que visam padronizar e impulsionar a inserção de parcela marginalizada da população em espaços de privilégio e poder até então com acesso muito restrito.

Nesse sentido, compreende-se como necessário e relevante investigar como se deu o percurso de formação da Lei de Cotas. Ao realizar o levantamento de informações que recompõe a formação da lei, acredita-se que será possível aprofundar o debate sobre o 
momento atual das cotas no país, em que o Estado brasileiro aderiu e padronizou as cotas nas Instituições Públicas de Ensino Superior. Ou seja, antes de 2012 não havia nenhum marco normativo federal para as instituições públicas que abordava o tema (haviam iniciativas de unidades federativas e de universidades federais, baseadas na autonomia universitária); a partir de 2012 quantitativo importante das vagas das instituições públicas federais passaram a ser reservadas, obrigatoriamente, para cotas.

Nota-se, então, que o Estado brasileiro passou a posicionar-se sobre a questão, e é nesse posicionamento que residem as dúvidas desta pesquisa: Quais atores participaram da formação da política? Quais discursos conflitaram e quais convergiram para que fosse possível esta lei? Por que em 2012? Qual o contexto institucional e político desse período? Quais as conexões entre os Poderes (Executivo, Legislativo e Judiciário) que propiciaram a formação da lei? Por que as cotas raciais foram transformadas em sub-subcotas? Sendo que a pergunta maior e central que direcionará os esforços dessa investigação é a seguinte: Como se formou a Lei de Cotas?

Sendo assim esta pesquisa procurou reconstruir o caminho de formação da política de cotas com o objetivo de compreender os fatos políticos e sociais que a impulsionaram. Iniciando pela análise documental da tramitação legislativa, em seguida analisando as notas taquigráficas das Audiências Públicas do Congresso Nacional, concluindo com reflexões gerais sobre todo o andamento legislativo da atual Lei. Entende-se que na medida em que as cotas nas universidades públicas estão asseguradas por lei federal ampliam-se os desafios relacionados à implementação, controle e avaliação dessa política. 


\section{CAPÍTULO 2}

\section{A TRAMITAÇÃO LEGISLATIVA DA LEI DE COTAS (LEI Nº 12.711/2012)}

Este segundo capítulo destina-se a compreender a tramitação legislativa da proposição que deu origem a atual Lei de Cotas. Entende-se aqui que esta lei é uma política pública de educação e é uma legislação responsável por um novo período de debate das ações afirmativas no país. A existência de uma lei federal sobre cotas para ingresso no ensino superior público estabelece parâmetros a serem seguidos por todas as instituições federais de ensino superior e técnico, bem como estabelece uma referência que influencia as formulações estaduais e municipais.

Nesse sentido, busca-se entender o período de formulação dessa lei, identificando atores e organizações sociais; conflitos e convergências; disputas e colaborações estabelecidas para que fosse possível a criação dessa legislação. Sabe-se que há uma distância e algumas dificuldades entre uma proposta formulada/escrita na lei e sua implementação concreta. Entende-se que, muitas vezes, a avaliação e possíveis reformulações das políticas ficam prejudicadas por fatores não-previstos no período de formulação.

A Lei de Cotas não está isenta dessas dificuldades e, apesar de seus poucos anos de existência, já são conhecidos alguns problemas da implementação, bem como algumas limitações na coleta de dados para sua avaliação. Porém, cabe aqui ressaltar que esse trabalho foca seu esforço analítico majoritariamente na fase inicial do ciclo da política, na formulação da lei.

Para iniciarmos cabe a reflexão sobre algumas questões conceituais mais abrangentes. A Constituição de 1988, denominada constituição cidadã, marca o início de uma nova era democrática no Brasil. Após anos de autoritarismo e inúmeras violações de direitos, o novo marco legal inaugura um período de maior independência entre os Poderes, proteção e defesa de direitos fundamentais, bem como a ampliação e a garantia dos direitos sociais. Reconhecendo os avanços da nova normativa constitucional, é imperativo dizer que resquícios autoritários no desenho institucional do Estado brasileiro se mantiveram, como por exemplo, a centralidade do Poder Executivo na produção legislativa (FIGUEIREDO e LIMONGI, 2001). 
Democracia é um importante conceito a ser explorado por essa dissertação, ainda que não seja o objetivo aqui detalhar minuciosamente a origem e desenvolvimento do termo, parece indispensável aderir a uma definição que contemple os objetivos deste trabalho. Sendo assim, optou-se por utilizar a conceitualização de Noberto Bobbio (2009):

(...) democracia, entendida como contraposta a todas as formas de governo autocrático, é (...) caracterizada por um conjunto de regras (primárias E fundamentais) que estabelecem quem está autorizado a tomar decisões coletivas e com quais procedimentos. (BOBBIO, 2009, p. 30)

Dentre os formatos possíveis de democracia estão a democracia representativa e a democracia participativa. Sabe-se que cada um desses termos abarca uma enorme quantidade de pressupostos e possibilidades de aplicação, contudo, de modo reduzido e simplificado, esse trabalho segue inspirando-se em Bobbio (2009) para delimitar as definições. Desse modo, entende-se que:

\begin{abstract}
A expressão democracia representativa significa genericamente que as deliberações coletivas, isto é, as deliberações que dizem respeito à coletividade inteira, são tomadas não diretamente por aquele que dela fazem parte, mas por pessoas eleitas para esta finalidade. [...]. Em outras palavras, um Estado representativo é um Estado no qual as principais deliberações políticas são tomadas por representantes eleitos, importando pouco se os órgãos de decisão são o parlamento, o presidente da república, o parlamento mais os conselhos regionais, etc (BOBBIO, 2009, p. 56-57).
\end{abstract}

Sabe-se que o modelo representativo tem sofrido inúmeras críticas e tem passado por reformulações em todo o mundo, devido à chamada crise de representação política. Em resposta, modelos institucionais com maior participação social têm sido formulados em distintos países, de modo que os sistemas políticos dialoguem mais com os cidadãos em seus processos decisórios. Nesse contexto, para os fins deste trabalho, utilizaremos a definição de Sell (2006) sobre a democracia participativa:

(...) um conjunto de experiências e mecanismos que tem como finalidade estimular a participação direta dos cidadãos na vida política através de canais de discussão e decisão. A democracia participativa preserva a realidade do Estado. Todavia, ela busca superar a dicotomia entre representantes e representados recuperando o velho ideal da democracia grega: a participação ativa e efetiva dos cidadãos na vida pública (op.cit., p. 93).

A Constituição de 1988 estabeleceu para o sistema político brasileiro um formato misto, ou seja, vivemos em uma democracia representativa com previsão legal para maior participação social. Alguns dos mecanismos de participação social na tomada de decisões políticas são: os plebiscitos, os referendos, os projetos de iniciativa popular, as audiências públicas, os conselhos e as conferências. A partir da redemocratização, o novo contexto político trouxe consigo novas oportunidades de interlocução entre sociedade civil e o Estado 
brasileiro, abrindo caminhos para o fortalecimento e a ampliação democrática (PEREZ, 2004).

Um dos elementos fundamentais na prática estatal são as políticas públicas. Conforme apresenta Celina Souza (2006), as políticas públicas, enquanto campo de estudos acadêmicos, comportam análises multidisciplinares posto que são ações que repercutem nas relações sociais, econômicas e políticas. Diversas áreas do conhecimento, então, estudam e analisam políticas públicas a partir de suas ferramentas teórico-metodológicas, o que possibilita a observação de um fenômeno a partir de várias perspectivas. Esse entendimento contempla o presente trabalho na medida em que aqui se buscará desenvolver a análise da formação de uma política pública usufruindo de recursos teórico-metodológicos da ciência política e da sociologia.

A formulação de uma política pública é o estágio em que um governo traduz seus propósitos e suas plataformas eleitorais em ações que produzirão resultados na realidade social (SOUZA, 2006). Dentre os modelos de formulação e análise de políticas públicas, escolheu-se para este trabalho a noção de ciclo da política pública. Essa tipologia compreende a política pública como um ciclo deliberativo, um processo dinâmico e de aprendizado institucional. Diversos autores dedicaram-se a estabelecer e descrever as etapas desse ciclo, que consistem basicamente em: formação de agenda, formulação de alternativas, processo decisório, implementação e avaliação (FRANÇA, 2007).

Ao analisar a tramitação legislativa da Lei de Cotas dividiu-se o capítulo nas seguintes partes: 1) Panorama sobre o ambiente político em que a Lei foi formulada (1999-2012); 2) Informações básicas sobre processo legislativo; 3) $\mathrm{O}$ andamento dos Projetos de Lei na Câmara; 4) O andamento dos Projetos de Lei no Senado; e 5) Considerações finais sobre a tramitação legislativa do Projeto de Lei.

\subsection{PANORAMA SOBRE O AMBIENTE POLÍTICO RELACIONADO ÀS AÇÕES AFIRMATIVAS}

\subsubsection{Histórico do Legislativo}

A sanção da Lei de Cotas foi precedida por um longo histórico de tramitação legislativa, que teve início na Câmara dos Deputados, com sua apresentação de projeto pela então deputada Nice Lobão (PFL/MA) no ano de 1999. Antes da apresentação deste projeto 
de lei, já haviam sido apresentadas outras matérias com o objetivo similar de beneficiar, por meio de cotas, um grupo específico que vivencia desvantagens socioeconômicas estruturais. Exemplo disso são as cotas para deficientes em concursos públicos ${ }^{27}$ ou as cotas para mulheres nos partidos políticos ${ }^{28}$.

Em relação à temática racial, sabe-se que a primeira proposta legislativa de cotas foi do deputado Abdias do Nascimento (PDT/RJ), o projeto de lei $n^{\circ} 1332 / 1983$. Este dispunha sobre ação compensatória, visando à implementação do princípio da isonomia social do negro em relação aos demais segmentos étnicos da população brasileira ${ }^{29}$. Essa proposta tramitou por seis anos na Câmara dos Deputados, tendo passado por três comissões, contando com pareceres favoráveis dos relatores e aprovação unânime nos colegiados. Contudo, o projeto de lei não chegou a ser votado pelo Plenário da Câmara e foi arquivado em 1989.

Em 1995, a senadora Benedita da Silva (PT/RJ) apresentou o projeto de lei do Senado $\mathrm{n}^{\circ} 14$, que dispunha sobre a instituição de cota mínima para os setores étnico-raciais socialmente discriminados em instituições de ensino superior públicas e particulares, nas esferas federal, estadual e municipal ${ }^{30}$. O projeto previa uma porcentagem de $10 \%$ de reserva de vagas nessas instituições. Na justificativa do projeto, a senadora argumenta que o número de vagas não era representativo da população negra, mas era uma estratégia para se abrir caminhos rumo à minimização das injustiças e da exclusão social. Ciente de que a iniciativa não resolveria o problema estrutural, a senadora Benedita (PT/RJ) entendia essa proposta como um primeiro passo.

Em 1997, o então senador Abdias do Nascimento (PDT/RJ) apresentou o novo projeto de lei do Senado $^{31} \mathrm{n}^{\mathrm{o}} 75$, que dispunha novamente sobre medidas de ação compensatória para implementação do princípio da isonomia social do negro. A proposição previa que todos os órgãos da administração pública direta e indireta, as empresas públicas e as sociedades de economia mista seriam obrigados a manter em seus quadros de servidores um percentual de $20 \%$ de homens negros e $20 \%$ de mulheres negras.

Herdeiros do legado de Abdias do Nascimento (PDT/RJ) no Congresso Nacional, alguns outros parlamentares negros também apresentaram propostas relacionadas à temática

\footnotetext{
${ }^{27}$ Lei $8112 / 1990$, artigo $5^{\circ}$, parágrafo $2^{\circ}$. Norma que estabelece $20 \%$ de reserva de vagas para candidatos com deficiência em concursos públicos.

${ }^{28}$ Lei 9504/1997, art. 10 e Lei 12.034/2009. Normas que estabelecem a obrigatoriedade de $30 \%$ de candidatas do sexo feminino por partido e coligação partidária.

${ }_{29}$ Disponível em: http://www.camara.gov.br/proposicoesWeb/fichadetramitacao?idProposicao=190742 (acesso em 10/10/2016)

${ }^{30}$ Disponível em: http://www25.senado.leg.br/web/atividade/materias/-/materia/24291 (acesso em 10/10/2016)

${ }^{31}$ Disponível em: http://www25.senado.leg.br/web/atividade/materias/-/materia/26657 (acesso em 10/10/2016)
} 
das ações afirmativas. Entre eles, por exemplo, a já referida Benedita da Silva (PT/RJ), Paulo Paim (PT/RS), Carlos Santana (PT/RJ), Luiz Alberto (PT/BA), Vicentinho (PT/SP), Janete Pietá (PT/SP) e Evandro Milhomen (PCdoB/AP).

De acordo com Moehlecke (2002), na década de 1990 havia quase uma dezena de projetos de lei sobre ações afirmativas em andamento no Congresso Nacional. No mesmo sentido afirma Fernandes (2011):

Entre 1993 e 2005, outras 38 proposições foram apresentadas dispondo sobre ações afirmativas, também designadas de "política de cotas", "reserva de vagas" e "ação compensatória", com diferentes propostas, entre elas, concessão de bolsas de estudo; estabelecimento de cota para negros, considerada uma política de reparação que, além de pagar uma indenização aos descendentes de escravos, propõe que o governo assegure a presença proporcional destes nas escolas públicas em todos os níveis; criação de um Fundo Nacional para o Desenvolvimento das Ações Afirmativas, e alteração no processo de ingresso nas instituições de ensino superior, estabelecendo cotas mínimas para a população negra, indígena e oriunda de escolas públicas (FERNANDES, 2011, p.40).

O início do século foi muito frutífero em termos de proposições legislativas dos estados da federação e dos municípios, sendo possível notar que matérias que tratavam sobre ações afirmativas e que incluíam a questão racial disseminaram-se por todo país (FERNANDES, 2010). Em 2001, por exemplo, Rio de Janeiro e Bahia tornaram-se os primeiros estados brasileiros que começaram a utilizar as cotas para ingresso em suas universidades.

Uma proposta muito importante que tramitou no Congresso Nacional entre 2000 e 2010 foi o Estatuto da Igualdade Racial. Sua versão inicial possuía significativos avanços sobre a temática racial no Brasil e, em se tratando das ações afirmativas, o projeto inicial previa, por exemplo, a instituição de cotas no ensino superior, nos serviços público e privado, vagas em partidos políticos para a candidatura a cargos eletivos proporcionais, além de vagas em filmes e propagandas veiculadas pelas emissoras de televisão e em peças publicitárias. Como nota-se, a proposta era abrangente e englobava várias possibilidades de utilização das ações afirmativas.

Contudo, no caso das propostas de ações afirmativas, pouco sobrou na versão final do projeto que se tornou lei. Nota-se que a proposta inicial trazia informações mais detalhadas sobre a forma de aplicação das ações afirmativas, ao passo que a versão final do projeto prevê as medidas de modo genérico e esparso, tanto na área educacional como em termos de mercado de trabalho. Assim, a proposta final suprime especificidades do projeto que viabilizariam a adoção concreta de ações afirmativas (SANTOS et al., 2011). 
O projeto de lei 73/1999, que daria origem à Lei de Cotas, tem seu tramite legislativo acelerado a partir de 2004, quando o Poder Executivo apresenta uma proposição sobre o assunto. A partir do momento em que o Poder Executivo encampa uma proposta sobre cotas nas Universidades, a discussão passa a desenvolver-se mais no Congresso Nacional. partir É neste momento que são realizadas Audiências Públicas na Câmara dos Deputados para debate do assunto, por exemplo.

E, em decorrência dessa tramitação mais célere e de aparente disposição política para se conduzir as discussões, algumas iniciativas populares importantes ocorreram, como por exemplo, a entrega de cartas de intelectuais contrários e favoráveis às ações afirmativas no Brasil. Em junho de 2006, o Manifesto "Todos têm direitos iguais na república democrática ${ }^{, 32}$ foi entregue ao Congresso Nacional com posicionamento contrário à política de cotas e ao Estatuto da Igualdade Racial. Em julho do mesmo ano, o Manifesto "Em favor da lei de cotas e do Estatuto da Igualdade Racial "33 também foi levado ao Congresso, agora com atores sociais favoráveis às cotas.

Outro fato interessante e que auxilia na compreensão desse contexto político legislativo foi a criação, na Câmara dos Deputados, em 2007, da bancada da Igualdade Racial, coordenada pelo Deputado Carlos Santana (PT/RJ) e que concentrou parlamentares interessados nesse debate. Outro dado interessante sobre a produção legislativa e a difusão das políticas de cotas nas instituições educacionais está no trabalho de Fernandes (2010), que informa que, das 236 instituições públicas de ensino superior do Brasil, 79 possuíam algum tipo de cotas, sendo que 42 adotavam cotas raciais. Dentre os estados da Federação, em 2010, 16 já possuíam alguma regulação sobre cotas raciais em suas instituições de ensino. Tais números apontam para a origem das cotas, em especial as cotas raciais no país, nas regulamentações locais, sejam elas as leis estaduais e municipais ou as resoluções dos Conselhos Universitários.

Neste sentido, é indispensável reconhecer que o início da normatização desse tema se deu no âmbito local, por iniciativa das próprias instituições educacionais, de estados e municípios. A proposta normativa que tramitou no Congresso Nacional foi influenciada, em alguma medida, por iniciativas dessas instituições locais e por propostas legislativas anteriores ao período de apresentação dessa matéria. Entretanto, este trabalho optou por

\footnotetext{
32 Íntegra disponível no anexo 4 desta dissertação.

33 Íntegra disponível no anexo 5 desta dissertação.
} 
investigar com maior acuidade o período contemporâneo ao trâmite do projeto de lei que ocorreram no âmbito federal.

\subsubsection{Histórico do Executivo}

Na década de 1990, no âmbito do poder executivo, ocorria o reconhecimento oficial por parte do então presidente Fernando Henrique Cardoso de que o Brasil é um país racista. Este reconhecimento ocorreu em uma declaração oficial dada pelo presidente durante sua participação no seminário “Multiculturalismo e Racismo”. Como consequência, também se reconheceu que medidas estatais precisavam ser adotadas a fim de se reverter as desigualdades estruturais. Nota-se que é a partir do reconhecimento do racismo presente no Estado brasileiro que ações começaram a ser planejadas e debatidas.

Assim, a realização do seminário supracitado em 1996, em Brasília, com objetivo de debater alternativas políticas para a questão racial brasileira, tornou-se um dos marcos da mudança do tratamento do Executivo federal. Entre as possibilidades abordadas no evento, as ações afirmativas figuravam como um projeto viável. No mesmo ano, com a divulgação do Programa Nacional dos Direitos Humanos $^{34}$, nota-se entre as propostas de ações governamentais para a população negra a meta $\mathrm{n}^{\circ} 141$, de médio prazo, era "desenvolver ações afirmativas para o acesso dos negros aos cursos profissionalizantes, à universidade e às áreas de tecnologia de ponta".

Essas propostas tiveram origem nas mobilizações do movimento negro brasileiro, conforme referido no capítulo anterior. A Marcha Zumbi do Palmares, ocorrida em 1995, tinha entre as reivindicações de seu documento oficial exatamente esse objetivo inserido no Programa Nacional dos Direitos Humanos. Outro desdobramento da Marcha foi a criação do Grupo de Trabalho Interministerial para valorização da população negra, que desenvolveu uma série de propostas e iniciativas a serem adotadas pelo Estado para se combater o racismo institucional.

Outras iniciativas foram formuladas e executadas ainda durante o governo de Fernando Henrique Cardoso, como o Grupo de Trabalho para a Eliminação da Discriminação

34 Disponível em: http://www.direitoshumanos.usp.br/index.php/Direitos-Humanos-no-Brasil/i-programanacional-de-direitos-humanos-pndh-1996.html (acessado em 15/01/2017) 
no Emprego e na Ocupação (GTDEO), que tinha sua base de atuação no Ministério do Trabalho com o objetivo de desenvolver programas e ações para o combate à discriminação no mercado de trabalho. Em 2002, por meio do Decreto ${ }^{\circ} 4.228$, foi instituído o Programa Nacional de Ação Afirmativa (PNAA) que previa reserva de vagas para ingresso no serviço público e para prestadores de serviço em alguns órgãos, estabelecendo metas para os cargos em comissão. A avaliação do programa realizada pelo IPEA $^{35}$, em 2012, indica que a implementação se deu de modo descontinuado e que os ministérios desconhecem o teor dessa norma. Dados que indicam como opera o racismo nas instituições brasileiras.

O Programa Bolsa-Prêmio de Vocação para a Diplomacia e o Programa Diversidade na Universidade eram modalidades diferentes de ações afirmativas, que não previam reserva de vagas nas seleções, mas disponibilizavam bolsas de estudos em cursos preparatórios a estudantes negros e indígenas. De acordo com Santos (2015), essas iniciativas foram implementadas já ao final do governo de Fernando Henrique Cardoso e se mostraram, desde o início, sem garantias para os beneficiários. Algumas avaliações desses programas apontam para resultados frágeis e passíveis de questionamento sobre a efetividade de suas ações.

Após a análise das principais iniciativas relacionadas à questão racial do governo Fernando Henrique Cardoso, é possível destacar que sua importância reside no fato de dar início à ruptura institucional com o mito da democracia racial. A adoção de um discurso oficial que considera o Brasil um país racista passa a tensionar a agenda política sobre essa questão, na mesma medida em que passa a incluí-la no debate público. Pode-se dizer que esse governo deu início às formulações de propostas de políticas públicas para a população negra brasileira.

No entanto, é necessário entender que mesmo com ganhos em termos simbólicos de incorporação da questão no discurso presidencial, de inclusão da temática em algumas formulações de políticas públicas, tudo isso ocorre de modo marginal e insuficiente. Mesmo com o reconhecimento por parte do Presidente da República sobre o racismo no Brasil, foram poucas políticas efetivamente implementadas, bem como seus resultados foram insatisfatórios.

A partir de 2003, com a chegada de um novo partido político e um novo presidente ao Executivo Federal, algumas modificações foram notadas. A começar pela criação da Secretaria Especial de Políticas de Promoção da Igualdade Racial (SEPPIR/PR), que nasceu

\footnotetext{
${ }^{35}$ Disponível na publicação Políticas Sociais: acompanhamento e análise, nº 20, 2012.
} 
com intuito de acompanhar, de modo transversal, as políticas públicas afetas à população negra. No mesmo ano, também, a sanção da Lei 10.639/2003, que dispõe sobre o ensino da História e Cultura Afro-Brasileira, que é um marco normativo importante na luta por uma educação antirracista. Outra ação foi a inclusão da categoria racial em algumas políticas sociais, como o Prouni (Programa Universidade para Todos), por exemplo.

Conforme expõe Santos (2015), tanto a criação da SEPPIR/PR como a sanção da Lei $10.639 / 03$, foram bastante custosas ao movimento negro. Um exemplo foi o fato da SEPPIR/PR ter sido efetivamente criada apenas meses depois do início do governo, não tendo sido anunciada juntamente com os demais Ministérios na posse do então Presidente Lula. O mesmo autor faz críticas à preferência do governo Lula na aprovação do Prouni em relação à Lei de Cotas, indicando que, apesar de haver aí uma iniciativa que atendia a demanda de maior inclusão no ensino superior, ao mesmo tempo a preferência pelo Prouni possibilitava ao governo não se posicionar abertamente favorável ou contrário às cotas raciais. Ao analisar o governo Lula, Feres Jr. et al. (2012) afirma o seguinte:

(...) medidas como o Fies e o Prouni, foram desenvolvidas para reverter um quadro que se consolidara no período de 1995 a 2002, quando o Presidente Fernando Henrique Cardoso implementou um modelo de expansão do ensino superior pela via do ensino privado, que não teria sido eficaz em ampliar o número de estudantes, gerando um grande número de vagas ociosas. Isso porque, entre outros problemas, o modelo esbarrava na dificuldade de incluir no ensino universitário privado uma população em idade universitária cuja baixa renda não lhe permitia arcar com os custos das mensalidades (FERES JR. et al, 2012, p. 405).

As políticas de promoção da igualdade racial inauguradas pelo governo Lula, mais que resultado de boa vontade política, foram consequência do exaustivo trabalho de convencimento e articulação do movimento negro. Assim como argumenta Matilde Ribeiro (2014):

(...) o Movimento Negro e a organização de mulheres negras têm sido, nas últimas décadas, referências estratégicas para a abertura de canais de negociação com o Estado e a sociedade, o que tem possibilitado o desenvolvimento das políticas de igualdade racial, sob a forma de ações afirmativas, visando atender às necessidades históricas da população negra brasileira (RIBEIRO, 2014, p.31).

Analisando os dois governos em termos de políticas relacionadas à temática racial, observa-se que o primeiro passo dado por FHC no sentido de iniciar a ruptura com o mito da democracia racial tem sequência nas ações de Lula, com a institucionalização da temática e a formulação de algumas políticas públicas. Dado o histórico secular de não-ação e completa negligência estatal ao tratar da questão racial, entende-se que as iniciativas desses dois 
presidentes dão início a uma nova postura do Estado brasileiro ao lidar com as desigualdades e o racismo institucional. Contudo, nota-se que a maior parte das ações foram tímidas comparadas as possibilidades existentes, como também essas ações e políticas sofreram diversos constrangimentos e limitações de ordem administrativa e orçamentária.

Ao observar especificamente a temática das ações afirmativas nesses dois governos, Santos (2015) oferece um bom resumo:

O presidente Fernando Henrique Cardoso, apesar de inaugurar mudanças nos discursos oficiais brasileiros e nos marcos normativos sobre a questão racial, não apoiava aquelas políticas explicitamente. O presidente Lula, apesar de explicitar verbalmente o apoio a tais políticas e criar a Secretaria Especial de Políticas de Promoção da Igualdade Racial (SEPPIR) no seu primeiro ano de governo, não implementou nenhuma política de ação afirmativa, de ingresso, para estudantes negros nas instituições de ensino público superior brasileiras (SANTOS, 2015, p.23).

Já o governo da presidenta Dilma Rousseff sancionou as duas legislações mais recentes e mais importantes para o objetivo desse trabalho, que são a Lei de Cotas e a Lei 12.990/2014. A primeira prevê a instituição de cotas nas Universidades e Institutos Tecnológicos e a segunda prevê cotas para negros em concursos públicos. Os dois primeiros anos do governo da presidenta foram marcados por duas decisões importantes no Supremo Tribunal Federal, a declaração de constitucionalidade das cotas e do PROUNI. Tais decisões possivelmente ampararam o governo em sua tomada de decisão. Assim como afirmou Luiza Bairros em entrevista ${ }^{36}$ de 2016 :

Outro eixo importante na nossa gestão foi o enfrentamento ao racismo institucional, estimulado por uma campanha que fizemos logo no início do governo, intitulada Igualdade Racial é para valer, exatamente para reforçar a incorporação de entes públicos e privados na tarefa de combate ao racismo. (...) mereceu desse governo uma importância muito grande com a adoção de ações afirmativas nos editais culturais. Isso estava vinculado a todo trabalho que tinha resultado no reconhecimento, pelo Supremo Tribunal Federal (STF), da constitucionalidade das ações afirmativas. Reforçados por isso, trabalhamos não só pela aprovação de cotas nas universidades públicas e institutos federais, mas também pelas ações afirmativas na cultura, cuja expansão, no período, foi bastante significativa."

(SANTOS e SOUZA, 2016, p.84)

Entre as críticas dos diversos movimentos sociais à Presidência da República, a dificuldade de diálogo era a mais recorrente, e em relação às questões raciais não era diferente. A presidenta Dilma não era muito acessível aos populares em comparação ao presidente que a antecedeu. $\mathrm{O}$ início de seu segundo mandato foi marcado por intensa instabilidade política e econômica, situação que exigiu reformas na estrutura estatal.

\footnotetext{
${ }^{36}$ Entrevista concedida à publicação SEPPIR - Promovendo a igualdade racial para um Brasil sem racismo (2016).
} 
Entre os órgãos extintos e/ou reagrupados estava a SEPPIR/PR. Sendo assim, em meados de 2015, a Secretaria perdeu o status de Ministério e foi agrupada à outras instituições como a Secretaria de Direitos Humanos (SDH/PR) e a Secretaria de Políticas para as Mulheres (SPM/PR), transformando-se no Ministério das Mulheres, da Igualdade Racial e dos Direitos Humanos. Essa iniciativa da presidência da república foi bastante criticada por parte da militância negra, que considerava que essa nova organização implicaria em maior restrição e diminuição das possibilidades de ações da SEPPIR/PR. Em entrevista, a então Ministra Nilma Gomes (2016) fez uma análise otimista do novo momento que a SEPPIR/PR passou a vivenciar:

(....) preciso dizer mais uma coisa: vivemos hoje um momento em que muitas pessoas têm uma leitura de que a SEPPIR foi extinta. Se considerarmos, a rigor, a configuração anterior da SEPPIR, quando esta possuía status de ministério, ela está, sim, extinta. Foi extinta por uma medida provisória. Mas, se levarmos em consideração que a SEPPIR continua vigorando como uma secretaria especial de políticas de promoção da igualdade racial dentro do novo Ministério, entendemos que ela passou por uma transformação, mas não por uma extinção. E mais: posso fazer uma outra leitura, também, a de que a nossa luta sempre foi para que nos tornássemos ministério de fato, e não que apenas tivéssemos status de ministério, o que nos limitava, como falei antes. E hoje, finalmente, somos um ministério. O nome do ministério é Ministério das Mulheres, da Igualdade Racial e dos Direitos Humanos (SANTOS e SOUZA, 2016, p.99).

Em comparação com os dois presidentes que a antecederam, o governo de Dilma Rousseff, para além do discurso e de ações simbólicas em prol da igualdade racial, apesar do pouco diálogo com os movimentos sociais, foi o responsável pela sanção de duas legislações sobre ações afirmativas. Iniciativas que terão efeito concreto na realidade social dos próximos anos no país.

A versão final do projeto de Lei 12.711/2012 é um complexo arranjo institucional para acomodar várias forças sociais e argumentos que estiveram em disputa no período de sua tramitação, como veremos na análise deste trabalho. Por ora, vale destacar o desenho da Lei de Cotas.

Está previsto que 50\% das vagas das instituições federais de educação superior e das instituições federais de ensino técnico são reservadas para estudantes que cursaram integralmente o ensino médio e fundamental em escolas públicas. Dentro dessas vagas, metade deve ser reservada a estudantes provenientes de famílias com renda igual ou inferior a 1,5 salário mínimo per capita. Além disso, está previsto que cada instituição destine proporcionalmente uma quantidade no mínimo igual dessas vagas de cotas aos pretos, pardos 
e indígenas de acordo com os dados fornecidos pelo IBGE (Instituto Brasileiro de Geografia e Estatística). A seguir ilustração.

Figura 4 - Esquema sobre a distribuição das vagas da Lei de Cotas

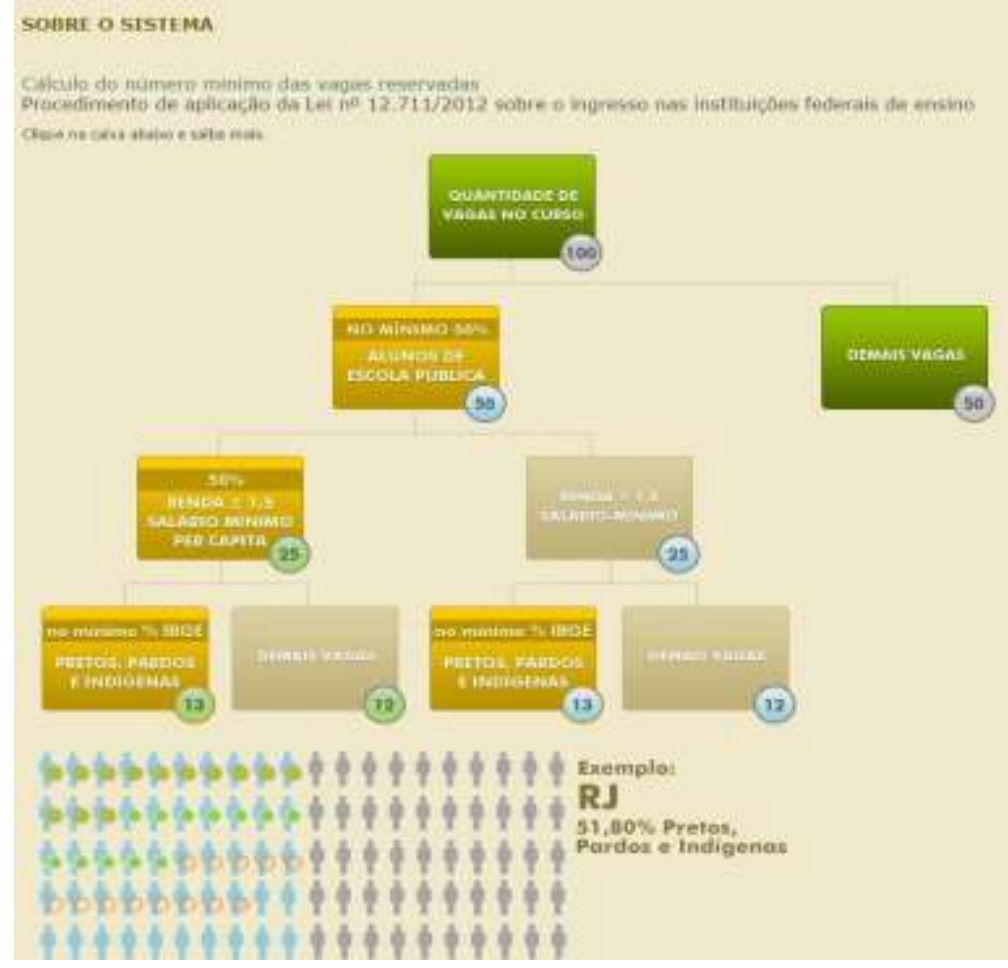

Fonte: Ministério da Educação (MEC)

Esta seção buscou apresentar algumas informações sobre o contexto legislativo, bem como o contexto do Executivo federal contemporâneos à formação da lei. Acredita-se que, a partir da compreensão de alguns aspectos gerais, seja possível entender melhor o processo de formação da Lei 12.711/2012. Passamos agora a uma breve explicação sobre processo legislativo, para em seguida apresentarmos como se deu a tramitação dos projetos que deram origem a Lei em estudo.

\subsection{INFORMAÇÕES BÁSICAS SOBRE PROCESSO LEGISLATIVO}

Sabe-se que o poder legislativo brasileiro é bicameral, sendo o Congresso Nacional composto pela Câmara dos Deputados e pelo Senado Federal. A criação de uma lei pode ser proposta por deputados e senadores, pelas Comissões da Câmara dos Deputados e do Senado 
Federal, pela Presidência da República, pelo Poder Judiciário, pelo Procurador-Geral da República e por iniciativa popular.

Ao se iniciar um projeto de lei, este é despachado pela mesa diretora da Casa para as Comissões Técnicas para análise de mérito e para a Comissão de Constituição e Justiça para análise dos aspectos jurídicos da proposta. A maioria das proposições legislativas iniciam sua tramitação na Câmara dos Deputados, e a aprovação de qualquer matéria depende bastante do tipo de pressão popular que existe em relação a ela. Nem todas as proposições passam pelo Plenário das Casas, e é possível que sua tramitação termine nas próprias Comissões, podendo ser arquivadas ou aprovadas. Esse é o chamado o poder conclusivo das Comissões, que é definido no despacho da Mesa Diretora.

Quadro 5 - Quadro explicativo sobre o poder conclusivo das comissões

\section{O que é o poder conclusivo das Comissões?}

\section{(Art.24, II, Regimento Interno da Câmara dos Deputados)}

As comissões podem discutir e votar projetos de lei, dispensada a apreciação do Plenário. O poder conclusivo das comissões segue a seguinte lógica:

(1) se aprovado por todas, será enviado para análise do Senado Federal sem a necessidade de deliberação do Plenário da Casa;

(2) se aprovados pareceres divergentes quanto ao mérito, as comissões perdem o poder conclusivo e o

próximo passo será a deliberação pelo Plenário da Casa;

(3) se rejeitado por todas as Comissões, ficará sujeito a arquivamento.

*Em todos os casos, será respeitado o prazo de 5 sessões ordinárias para interposição de recurso contra a apreciação conclusiva das comissões. O recurso deve ser apresentado por, no mínimo, 1/10 dos membros da Casa e necessariamente deve ser aprovado pelo Plenário. No caso de aprovação, o projeto deve passar pelo crivo do Plenário da Casa.

Fonte: produzido pela autora

Após ser aprovado na casa iniciadora/criadora, as matérias são encaminhadas à casa revisora. No caso da proposição aqui estudada, a proposta teve início na Câmara dos Deputados e o Senado Federal foi a casa revisora. Na situação de casa revisora, o Senado Federal poderia: 1) aprovar alterações ao texto proveniente da Câmara dos Deputados, o que acarretaria o retorno do projeto a esta Casa, para análise das modificações pelas mesmas Comissões, que o apreciaram em um primeiro momento; 2) aprovar o projeto sem modificações, remetendo-o para sanção presidencial; ou 3) rejeitar a proposição, que seria arquivada definitivamente. Ao final de cada legislatura, findado o período de quatro anos, 
todas as proposições são arquivadas e as condições de desarquivamento encontram-se explicadas no quadro a seguir.

Quadro 6 - Casos de desarquivamento de proposição

\begin{abstract}
Desarquivamento de proposição
Finda a legislatura, arquivar-se-ão todas as proposições que no seu decurso tenham sido submetidas à deliberação da Câmara e ainda se encontrem em tramitação, bem como as que abram crédito suplementar, com pareceres ou sem eles, salvo as:

(1) com pareceres favoráveis de todas as Comissões;

(2) já aprovadas em turno único, em primeiro ou segundo turno;

(3) que tenham tramitado pelo Senado, ou dele originárias;

(4) de iniciativa popular;

(5) de iniciativa de outro Poder ou do Procurador-Geral da República.

A proposição pode ser desarquivada mediante requerimento do autor, ou autores, dentro dos primeiros 180 dias da $1^{\text {a }}$ sessão legislativa ordinária da legislatura subsequente. Nesse caso, retorna a tramitação desde o estágio em que se encontrava.

*A legislatura tem duração de quatro anos e coincide sempre com a duração do mandato dos deputados.

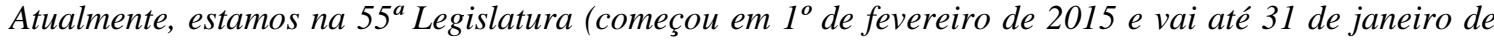
2019). Legislatura é diferente de sessão legislativa, que consiste no período de trabalho parlamentar durante o ano. A sessão legislativa ordinária se inicia em 2 de fevereiro e termina em 22 de dezembro.
\end{abstract}

Fonte: Produzido pela autora

Após a aprovação no Congresso Nacional, as matérias seguem para sanção da Presidência da República, que poderá vetar o projeto total ou parcialmente. Os parlamentares, por sua vez, podem confirmar ou derrubar o veto. De modo bastante genérico, esse é o trâmite necessário para que um projeto se transforme em lei. A seguir, passaremos a descrição detalhada do trâmite do projeto estudado, começando pela Câmara dos Deputados.

\title{
2.3 TRAMITAÇÃO DO PROJETO DE LEI NA CÂMARA DOS DEPUTADOS
}

PL 73/1999 - Dispõe sobre o ingresso nas universidades federais e estaduais e dá outras providências.

A proposta foi apresentada pela Deputada Nice Lobão (DEN/MA) em fevereiro de 1999, e em março do mesmo ano foi distribuída pela Mesa Diretora da Casa para a Comissão de Educação, Cultura e Desporto (CEC) e para a Comissão de Constituição e Justiça (CCJ). 
Em julho de 2004, o despacho de designação foi revisado, e a Comissão de Direitos Humanos e Minorias foi agregada aos locais de tramitação da proposta. Na Câmara há uma diferenciação entre as chamadas comissões de mérito e a Comissão de Constituição, Justiça e Cidadania. As comissões de mérito são aquelas responsáveis por avaliar o conteúdo das propostas legislativas, enquanto à Comissão de Constituição, Justiça e Cidadania deve se ater ao aspecto jurídico das matérias.

Figura 7 - Imagem do PL 73/1999

\title{
PROJETO DE LEI № 73, DE 1999 \\ (Da Sra. Nice Lobão)
}

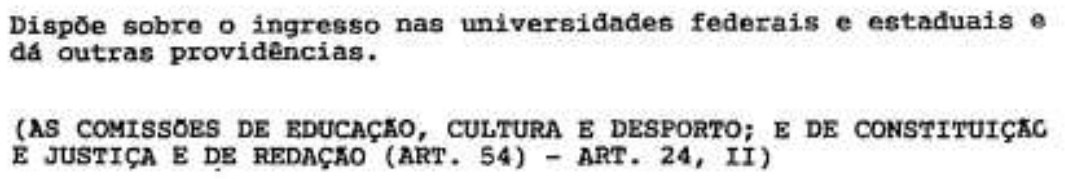

\section{O CONGRESSO NACIONAL DECRETA:}

\begin{abstract}
"Art. $1^{\circ}$ - As universidades públicas reservarão $50 \%$ f́cinqûenta p cento) de suas vagas para serem preenchidas mediante seleçio de alunos nos cursos do ensino médio, tendo como base o Coeficiente de Rendimento - C CR, obtido através da médila aritmética dns notas ou menpöes obtidas no periodo, considerando-se o curriculum comum a ser estabelecido pelo Ministério da Educaş̃̃o e do Desporto.

Paraigrafo único - É facultada is universidades particalares, o mesmo disposto para as universidades públicas.

Art. $2^{\circ}$ - O Poder Executivo regulamentara a presente Lei no prazo de 180 (cento e oiteuta) dias a contar de sua poblicaço, observando:

I - capracitaçiio do corpo docente, mediante a titulacto dos professores, assim como seu desempenho profissional, avalisdo por meio da análise curricular dos mesmos;

II- nivel salarial dos professores;

ensino.

III - qualidade das bibliotecas, laboratónios, equipamentos e materiais de

Parágrafo único - A regulamentaç̃o đisporã sobre os critérios de credenciamento das escolas de ensino médio para os fins previstos nesta Lei.
\end{abstract}

Art. $3^{\circ}$ - Esta Lei entra em vigor trés anos após a sua promulgą̧̇o.

Art. $4^{\circ}$ - Revogam-se as disposiçōes em contrário.

Sala das Sessōes em

de

de 1999

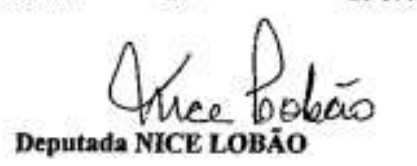

O projeto apresentado pela Deputada Nice Lobão (DEM/MA) era bastante objetivo com apenas quatro artigos. Note-se que nenhum deles faz referência ao critério racial. A principal ideia era a reserva de vagas nas universidades públicas para estudantes do ensino 
médio com rendimento escolar satisfatório e mensurável. Na justificativa da proposição, a autora demonstra preocupação com a qualidade e o acesso ao ensino superior; fazendo uma menção crítica à seleção por meio de vestibulares. Sua proposta, então, seria a de manter metade do acesso às vagas no ensino superior por meio dos vestibulares e a outra metade reservada aos estudantes do ensino médio que possuíssem rendimento escolar satisfatório e mensurável. Importante ressaltar que essa versão inicial não possuía nenhum dos critérios de reserva de vagas utilizados na versão final da Lei de Cotas - critério social e racial, posteriormente incorporados.

Como nota-se na tabela a seguir, a proposição tramitava vagarosamente pela Câmara dos Deputados, com algumas trocas de relatores e a apresentação de alguns relatórios sem apreciação pela Comissão. Aparentemente, nos primeiros cinco anos de tramitação da matéria não havia consenso suficiente para que a proposta avançasse em seu percurso, e, talvez por isso, tenha permanecido na mesma Comissão sem ser pautado para votação nenhuma vez nesse período.

Quadro 8 - Designações do PL 73/1999 ocorridas no período de 1999 a 2005

\begin{tabular}{|c|c|l|}
\hline DESIGNAÇ̃̃o & PARLAMENTAR & \multicolumn{1}{|c|}{ SITUAÇÃo } \\
\hline $08 / 04 / 99$ & $\begin{array}{c}\text { Gastão Vieira } \\
\text { (PMDB/MA) }\end{array}$ & Devolveu sem manifestação em 03/05/99 \\
\hline $06 / 05 / 99$ & Celcita Pinheiro (PFL/MT) & Apresentou parecer pela rejeição \\
\hline $17 / 08 / 99$ & Pedro Wilson (PT/GO) & $\begin{array}{l}\text { Apresentou parecer contrário ao PL 73/99, } \\
2.069 / 99 \text { e favorável ao PL 1.447/99, apensado, } \\
\text { com substitutivo }\end{array}$ \\
\hline $23 / 03 / 00$ & $\begin{array}{c}\text { Bonifácio de Andrada } \\
\text { (PSDB/MG) }\end{array}$ & Devolveu sem manifestação \\
\hline $04 / 10 / 00$ & $\begin{array}{c}\text { Professor Luizinho } \\
\text { (PT/SP) }\end{array}$ & $\begin{array}{l}\text { Apresentou manifestação favorável, com } \\
\text { substitutivo, o qual recebeu uma emenda }\end{array}$ \\
\hline $18 / 03 / 05$ & $\begin{array}{c}\text { Carlos Abicalil (PT/MT) } \\
\text { Apresentou manifestação favorável à } \\
\text { proposição principal e aos PLs 615/03, 1.313/03 } \\
\text { e 3.627/04, apensados, com substitutivo. }\end{array}$ \\
\hline
\end{tabular}

Fonte: Política de cotas raciais para ingresso em instituições públicas de ensino superior no Brasil: Ausência de Política Pública. Anamélia Fernandes (2010).

Por isso, para os objetivos desse trabalho, optou-se por analisar com mais detalhes os acontecimentos da tramitação a partir do ano de 2004. Deste ano em diante a matéria passa a 
tramitar com celeridade um pouco maior, e mais atores se envolvem com a discussão da proposta.

Conforme indica o site da Câmara dos Deputados, em 2004, a autora Deputada Nice Lobão (DEM/MA) apresentou requerimento solicitando desapensamento do PL 1.643/1999, ao mesmo tempo que solicitava apensação ao PL 3.627/2004. Isso significa que a autora pediu para que passasse a tramitar junto com a sua proposta o projeto de lei do Poder Executivo, uma demonstração de que as propostas se aproximavam e poderiam caminhar conjuntamente.

Mais do que compreender os procedimentos do trâmite legislativo, interessa notar quais eram as propostas que estavam em questão no processo. $\mathrm{O}$ desapensamento se referia ao projeto de lei do então senador Antero Paes de Barros (PSDB/MT), que versava sobre a reserva de $50 \%$ de vagas das universidades públicas para estudantes que tivessem cursado integralmente ensino fundamental e médio em escolas públicas. A apensação era ao projeto de lei do Poder Executivo Federal, que tinha por objetivo instituir um sistema de reserva de vagas para estudantes egressos de escolas públicas, em especial negros e indígenas.

Vale destacar as diferenças importantes das duas proposições. A proposta do senador do PSDB previa que os estudantes aptos a concorrer às vagas seriam aqueles que houvessem cursado integralmente ensino fundamental e médio em escolas públicas, sendo que essas vagas seriam ocupadas nas Universidades Públicas. A proposta proveniente do Poder Executivo indicava de modo menos específico que os beneficiários fossem aqueles egressos de escolas públicas, e incluía a discussão de raça e etnia na distribuição das vagas. Além disso, propunha a iniciativa para todas as Instituições Públicas Federais de Educação Superior, o que engloba, além das universidades, os centros universitários, os institutos e as faculdades ${ }^{37}$.

Ao reiniciar sua tramitação, o Deputado Carlos Abicalil (PT/MT) foi designado relator na Comissão de Educação, Cultura e Desporto. O PL 615/2003 foi apensado. O parecer emitido pelo relator foi pela aprovação do projeto de lei em questão (73/1999), e também pela aprovação de outros projetos de lei apensados, com os substitutivos.

\footnotetext{
${ }^{37}$ Conforme o Decreto $\mathrm{n}^{\mathrm{o}}$ 5.773/2006 as instituições de educação superior (IES) podem ser credenciadas com faculdades, centros universitários ou universidades. Inicialmente todas são cadastradas como faculdades, após cumprirem alguns requisitos do MEC poderão tornar-se centros universitários e universidades. Decreto disponível em: <http://portal.mec.gov.br/seed/arquivos/pdf/legislacao/decreton57731.pdf>.
} 
É interessante descrever brevemente o teor dessas propostas que tramitavam em conjunto para se compreender quais pautas políticas estavam em questão nesse momento. $\mathrm{O}$ PL 615/2003 dispõe sobre a obrigatoriedade de vagas para índios que forem classificados em processos seletivos, sem prejuízo das vagas abertas para os demais alunos. O PL 1.313/2003 busca a instituição do sistema de cota para a população indígena nas instituições de ensino superior. O PL 3627/2004 prevê a instituição de um Sistema de reserva de vagas para estudantes egressos de escolas públicas, em especial negros e indígenas, nas instituições públicas federais de educação superior.

O relatório do deputado Carlos Abicalil (PT/MT) é simples, sem referências acadêmicas ou jurídicas. São apresentados as proposições em análise e o voto. As justificativas do voto são convergentes com as argumentações presentes no PL 3.627/2004, do Poder Executivo. O relator informa que construiu uma proposta substitutiva ao projeto original com a participação de entidades representativas de reitores, docentes, estudantes e responsáveis por cursos preparatórios para vestibulares entre negros e carentes.

Ainda no relatório, a afirmação do deputado Carlos Abicalil (PT/MT) chama a atenção: "É interessante ressaltar a racionalidade da proposição, na medida em que estabelece critérios específicos relativos às etnias, com critérios universais de renda”. Esse trecho faz referência a formulação do projeto de lei de autoria do Poder Executivo. Desse modo, nota-se que há prioridade ao critério universal e relacionado à renda em detrimento dos critérios de raça e de etnia; sendo que, de acordo com o relator, essa formulação denota racionalidade. A construção de uma narrativa que reforça a ideia de que a questão racial é subsidiária à questão de classe, no caso deste projeto de lei, inicia-se nesse momento da tramitação.

É a proposta substitutiva deste deputado que inclui na discussão o ensino técnico de nível médio. Além disso, em seu voto, o relator afirma sua preocupação em especificar que a reserva de vagas deve incluir cada curso e turno, de modo a não se restringir aos cursos menos concorridos. Outro aspecto relevante da formulação da política é o estabelecimento de prazos para sua implementação, sendo que na proposta do deputado Abicalil (PT/MT) o prazo de quatro anos foi estipulado para que as exigências da proposta fossem cumpridas pelas instituições federais.

Desse modo, da proposta inicial do projeto para a versão apresentada pelo relator da Comissão de Educação, Cultura e Desporto permaneceu o seguinte: 1) a proporção de vagas a 
serem reservadas; 2) a referência a um coeficiente de rendimento a ser utilizado para selecionar os estudantes, e 3) a parte que faculta às instituições privadas adotar o mesmo procedimento. Abaixo a versão que permaneceu da ideia original da proposição:

\footnotetext{
Art. $2^{\circ}$. As universidades públicas deverão selecionar os alunos advindos do ensino médio em escolas públicas tendo como base o Coeficiente de Rendimento - CR, obtido através de média aritmética das notas ou menções obtidas no período, considerando-se o curriculum comum a ser estabelecido pelo Ministério da Educação e do Desporto.

Parágrafo único. As instituições privadas de ensino superior poderão adotar o procedimento descrito no caput em seus exames de ingresso.
}

Além das modificações já citadas, o relator também propôs:

1) As instituições públicas federais de educação superior, que inclui além das Universidades, os centros universitários, as faculdades e os institutos;

2) Estudantes que tivessem cursado integralmente o ensino médio em escolas públicas seriam os primeiros beneficiários da lei;

3) Que as vagas sejam preenchidas, por curso e turno, por autodeclarados negros e indígenas, em proporção no mínimo igual à proporção de autodeclarados no último Censo Demográfico do IBGE;

4) A definição de que vagas remanescentes seriam destinadas a estudantes que tenham cursado integralmente o ensino fundamental em escolas públicas.

5) A inclusão das escolas técnicas de nível médio na reserva de vagas.

6) Responsáveis pelo acompanhamento e avaliação do programa o Ministério da Educação e a Secretaria Especial de Políticas de Promoção da Igualdade Racial, sendo ouvida a Fundação Nacional do Índio - FUNAI.

7) Formas de implementação com um prazo de quatro anos, com um mínimo de $25 \%$ ao ano. E que em dez anos ocorrerá a revisão do programa.

Em setembro de 2005, a Comissão aprovou por unanimidade o parecer do relator deputado Abicalil (PT/MT). O site da Câmara dos Deputados não oferece informações detalhadas sobre quais parlamentares discutiram a proposta no dia da deliberação, nem quais deputados votaram a matéria.

No mesmo ano, a matéria foi recebida pela Comissão de Direitos Humanos e Minorias e a deputada Iriny Lopes (PT/ES) assumiu a relatoria do projeto. Em novembro, foi apresentado parecer pela aprovação do PL 73/1999 e dos projetos de lei $n^{\circ} 3627 / 2004, n^{\circ}$ 
615/2003 e n 1.313/2003. O relatório da Deputada Iriny Lopes (PT/ES) é bastante desenvolvido, detalhando cada uma das propostas legislativas e as argumentações apresentadas por seus autores.

Sobre o PL 73/1999, a relatora destaca o que apresenta a Deputada Nice Lobão (DEM/MA) em sua justificativa, que o ideal seria a extinção dos vestibulares, contudo por não ser possível nesse momento buscava-se esse objetivo gradualmente reservando $50 \%$ das vagas do padrão convencional para ingresso na universidade.

Em relação ao PL no 615/2003, a relatora ressaltou que a proposta tratava de matricular os indígenas que conseguissem aprovação no processo seletivo em novas vagas "ficando, assim, resguardados o sistema de mérito acadêmico e os direitos dos demais candidatos aprovados". Sobre o PL n ${ }^{\circ} 1.313 / 2003$ a relatora afirma que a proposta seria de disponibilizar entre os anos de 2003 e 2020 vagas nas universidades que seriam destinadas à população indígena, na proporção estabelecida pela lei em cada estado da Federação. A essas propostas não houve nenhuma emenda apresentada pela Comissão.

Sobre o PL no 3.627/2004, de autoria do Poder Executivo, a relatora enfatiza que “(...) o texto da proposição adota a política de cotas de forma racional, distribuindo-as pela composição étnico racial das unidades federativas". A essa proposta foram apresentadas 10 emendas na Comissão, porém nenhuma foi acatada pela relatora. As propostas de emendas variaram em seus conteúdos e sugeriam modificações como: o acréscimo do termo 'pardos', uma nova redação para se separar as cotas étnicas das cotas sociais; a extensão das cotas ao ensino técnico, agrotécnico, tecnológico médio e superior; a delimitação de vagas por curso, turno e unidade; a aplicação da proporcionalidade em todos os cursos; a ampliação do regime de cotas para vagas da pós-graduação; e por fim, a necessidade de adoção de medidas especiais para permanência dos cotistas, de modo a promover seu acesso ao mercado de trabalho.

Os Deputados que apresentaram propostas foram Mário Heringer (PDT/MG), Neucimar Fraga (PR/ES), Maria do Rosário (PT/RS) e Luiz Alberto (PT/BA). Nenhuma das propostas de emendas foi aceita. A fundamentação do voto da relatora foi desenvolvida em torno do argumento de que é necessário superar as desigualdades sociais, afirmando que nos últimos séculos têm sido adotadas políticas que visam à garantia de oportunidades iguais, em especial no campo da educação. A relatora cita ainda os Estados Unidos como uma referência na formação de uma escola pública acessível. 
A deputada conclui afirmando a necessidade de novas regras de acesso ao ensino superior para que seja possível o desenvolvimento social com igualdade e justiça. E concordando com o parecer do deputado Carlos Abicalil (PT/MT) reafirma que "a adoção da política de reserva de vagas na educação constitui-se em uma das formas mais importantes de políticas afirmativas. " Decidindo, portanto, pela aprovação do Substitutivo apresentado na Comissão anterior que, segundo a autora, sintetiza com objetividade os dispositivos dos projetos de lei sob análise.

Sobre o debate racial que passou a ser uma questão na proposição, destaca-se no relatório o entendimento de que as relações de força, dominação e exploração se perpetuaram no Brasil ao longo de muitos anos, e que, por isso, é necessário o desenvolvimento de políticas que modifiquem essas relações desiguais. Outro aspecto que merece atenção no relatório é a justificativa da relatora em favor da combinação dos critérios raciais e sociais, como nota-se na íntegra abaixo:

\begin{abstract}
Neste sentido, concordamos com os nobres autores das proposições que estamos a analisar. Em suas justificações, e, em especial, na Exposição de Motivos do Sr. Ministro da Educação, percebe-se com nitidez o desejo e o empenho dos autores, em criar, pela via legislativa, na área do ensino público de nível superior, mais um instrumento de promoção da igualdade social.

E, de modo inteligente, combinam critérios de inclusão por razões étnicas com critérios de renda para acesso ao ensino público superior, pois asseguram o ingresso nas universidades públicas aos estudantes egressos do sistema público de ensino fundamental e médio. Não abandonam, no entanto, critérios relacionados ao conhecimento intelectual dos estudantes, pois são beneficiados somente os candidatos que demonstrem sua capacidade intelectual em concursos de seleção para ingresso nos cursos de graduação.
\end{abstract}

Em dezembro de 2005, o parecer foi aprovado por unanimidade pela Comissão de Direitos Humanos e Minorias. Participaram da sessão os seguintes deputados: Iriny Lopes (PT/ES), Luiz Couto (PT/PB), Pompeo de Mattos (PDT/RS), Chico Alencar (PSOL/RJ), Leonardo Mattos (PV/MG), Luci Choinacki (PT/SC), Mário Heringer (PDT/MG), Orlando Fantazzini (PSOL/SP), Ana Guerra (PT/MG), Eduardo Barbosa (PSDB/MG) e Geraldo Thadeu (PSD/MG).

Em seguida, o projeto foi para a Comissão de Constituição, Justiça e Cidadania, onde o deputado Luiz Alberto (PT/BA) foi designado relator e apresentou parecer pela constitucionalidade, juridicidade e técnica legislativa. $\mathrm{O}$ projeto foi redistribuído à deputada 
Iara Bernardi (PT/SP), que apresentou parecer pela constitucionalidade, juridicidade e técnica legislativa. Em fevereiro de 2006, o parecer foi aprovado por unanimidade pela Comissão.

O parecer da relatora resume o trâmite da matéria até então, e apresenta algumas alterações que têm impacto no escopo da proposta. Quanto à juridicidade, a relatora afirma que, ao atribuir ao Ministério da Educação (MEC) a fixação de currículo mínimo para o ensino médio, a proposição choca com a Lei $n^{\circ}$ 9.131/1995, que estabelece ser função da Câmara de Educação Básica do Conselho Nacional de Educação estabelecer diretrizes curriculares nacionais para essa etapa do ensino. Além disso, conforme as atuais diretrizes para o ensino médio há autonomia por parte dos sistemas de ensino e das escolas para sua organização curricular, de modo que se torna inviável, de acordo com a deputada, a centralização dessa atividade pelo Ministério da Educação.

Portanto, a relatora deputada Iara Bernardi (PT/SP) propôs duas emendas: a primeira que restringe as instituições federais de educação superior àquelas vinculadas ao MEC; a segunda emenda especificou que as vagas reservadas nas instituições federais de ensino técnico de nível médio deveriam ser em todos os cursos e turnos. Importante notar que a primeira modificação implica em retirada das instituições federais de educação superior militares, limitando a proposição às instituições vinculadas ao Ministério da Educação.

Conforme afirmou Renato Ferreira em entrevista realizada para esta pesquisa, em 30 de outubro de 2015, essa exclusão revela os atores que estavam interessados e envolvidos nessa discussão. Segundo o entrevistado, os militares articularam politicamente para que essa legislação não envolvesse as instituições militares. Sendo assim, as instituições federais de ensino militar não foram abarcadas por essa proposta legislativa.

Caso se mantivesse com apreciação conclusiva, a matéria terminaria seu trâmite na Câmara dos Deputados nesse momento. Contudo, foi apresentado no plenário um requerimento contra a apreciação conclusiva pelo deputado Alberto Goldman (PSDB/SP).

Em março de 2006, o deputado Miro Teixeira (PPS/RJ) apresentou requerimento para que a matéria passasse a tramitar em regime de urgência, que foi aprovado. Tramitar em regime de urgência significa que algumas exigências e formalidades regimentais são dispensadas, com exceção da publicação e distribuição dos avulsos e cópias, dos pareceres das Comissões e do quórum para deliberação. Sendo assim, a matéria passou direto para apreciação do Plenário da Câmara dos Deputados. 
Esse tipo de movimentação legislativa demonstra que o assunto mobilizava alguns interesses na Casa, ou seja, tanto a perda do caráter conclusivo que implicou na passagem da proposição pelo Plenário da Câmara dos Deputados, como o pedido de urgência para a matéria são fatos que indicam estratégias de tramitação legislativa para que o projeto fosse apreciado de modo mais rápido e por mais parlamentares. Nesse caso, também há indícios de que a oposição procurava criar obstáculos para a tramitação da matéria, uma vez que, passando pelo Plenário, a dificuldade de aprovação é significativamente maior.

Como observamos anteriormente, a discussão sobre ações afirmativas, e mais especificamente sobre cotas para negros, estava a todo vapor neste período, e não apenas dentro do Congresso Nacional, mas na mobilização de grupos da sociedade civil contrários e a favor das cotas, que entregaram manifestos à presidência da Câmara e do Senado em 2006.

Assim, a tramitação legislativa e a tomada de decisão dentro do Legislativo nacional mobilizava várias forças e interesses sociais. Alguns dos principais argumentos que foram utilizados pelos parlamentares estavam presentes nesses manifestos. O grupo contrário preocupava-se com a criação de uma divisão racial artificial, que, de acordo com eles, ainda não existia no Brasil; o grupo favorável apontava a extrema desigualdade racial nos bancos universitários e a necessidade de reversão desse quadro. O que se observa é a existência de diálogo e pressão da sociedade civil em relação ao Congresso Nacional.

Ainda no ano de 2006, a deputada Neyde Aparecida (PT/GO) solicitou a realização de um seminário conjunto com a Comissão de Direitos Humanos para discutir a proposta de cotas no ensino superior e realizou-se uma Audiência Pública. O próximo capítulo dessa dissertação tratará especificamente das Audiências Públicas realizadas no Congresso Nacional.

Até aqui, a matéria já havia tramitado por três comissões, sendo discutida em todas, mas votada em apenas duas delas e encaminhada direto para a apreciação, discussão e votação no Plenário da Câmara dos Deputados. Em 20 de novembro de 2008, a proposta foi colocada em discussão no plenário. A liderança do PSDB, na pessoa do deputado Emanuel Fernandes (PSDB/SP), havia solicitado o adiamento da votação por duas sessões, pedido que foi retirado (provavelmente por algum acordo). Esse pedido indica alguma resistência ou discordância à proposta por parte da oposição. Dois deputados discutiram a proposição: Rodrigo Rollemberg (PSB/DF) e Gerson Peres (PP/PA). 
Para discutir favoravelmente a matéria, o então deputado Rodrigo Rollemberg $(\mathrm{PSB} / \mathrm{DF})^{38}$ elogiou a Câmara dos Deputados e o governo do presidente Lula (PT) por pautar essa relevante matéria para a educação superior brasileira. Fez referência à notícia veiculada no jornal Correio Brasiliense, que divulgou uma reportagem sobre uma pesquisa com estudantes cotistas da UnB que possuíam bom rendimento acadêmico. Argumentou que o projeto de lei em pauta promoveria a democratização do ensino superior e a melhoria das escolas públicas de ensino fundamental e médio, de modo a se pensar educação de maneira integrada.

Para discutir contrariamente a matéria, o Deputado Gerson Peres (PP/PA) afirmou que considerava estranho o estabelecimento de reserva de vagas, por que isto fere princípios igualitários. De acordo com o parlamentar, "o bom senso nos diz que é mais seguro a disputa em condição de igualdade”. Argumentou, também, que as condições igualitárias beneficiariam muito os negros, que estão cada vez mais ganhando condições de acesso à escolarização. Mencionou, inclusive, que vários negros alcançam destaque sem precisar da reserva de vagas. Defendeu que o princípio da igualdade da Constituição faz com que essa proposição não tenha amparo constitucional. E, por fim, o deputado afirmou que era um erro que as associações não compreendessem que há mais vantagens na competição em condições de igualdade, isso por que, quando as porcentagens de vagas reservadas estivessem preenchidas, não seria possível competir pelas demais vagas. Acredito que aqui o parlamentar se refere a alguns sistemas implementados pelo país, em que se colocam as cotas como um teto de vagas reservadas e não como um piso.

Em seguida foram apresentadas duas emendas do Plenário ao projeto, sendo escolhidos parlamentares das Comissões para proferirem pareceres a respeito dessas emendas. Da Comissão de Educação e Cultura (CEC), o Deputado Luiz Couto (PT/PB) concluiu pela rejeição da emenda de plenário 1 e pela aprovação da emenda de plenário 2 , na forma de subemenda substitutiva. Pela Comissão de Direitos Humanos e Minorias, o deputado Colbert Martins (PMDB/BA) concluiu pela aprovação da emenda de plenário 2. Da Comissão de Constituição, Justiça e Cidadania, o deputado Fernando Coruja (PPS/SC) proferiu parecer que concluiu pela constitucionalidade, juridicidade e técnica legislativa das duas emendas de plenário e da subemenda substitutiva.

\footnotetext{
${ }^{38}$ Informações extraídas de áudio de sessão plenária disponível no site da Câmara dos Deputados.
} 
Desse modo, a emenda 1 foi reprovada, e não foi possível localizar o inteiro teor de seu conteúdo. A subemenda substitutiva 2 apresentada pelo relator da CEC, Luiz Couto (PT/PB), foi aprovada. A aprovação dessa emenda trouxe ao projeto a inclusão do seguinte parágrafo único: "No preenchimento das vagas de que trata o caput deste artigo, 50\% deverão ser reservadas aos estudantes oriundos de famílias com renda igual ou inferior a 1,5 salário mínimo per capita”.

Sendo assim, é no Plenário da Câmara dos Deputados que a questão de classe é incorporada de modo mais explícito. A questão racial nesse momento perde força e passa a estar subsumida à questão de classe (que conta com dois critérios). Em discussões sociológicas, a associação da questão de classe social com renda é bastante usual, bem como ainda são comuns os discursos que indicam que o problema da desigualdade de acesso ao ensino superior no Brasil não tem a ver com a questão racial, mas sim com a questão da pobreza ou da classe social. A inclusão desse parágrafo evidencia como esse debate sobre classe e raça se colocam na disputa política.

Além disso, outra modificação foi a inclusão de pardos entre os autodeclarados, uma vez que, até esse momento, havia a previsão de que apenas autodeclarados negros e indígenas poderiam ter acesso à reserva de vagas. Esta modificação considera que a junção entre autodeclarados pretos e pardos, de acordo com as categorias utilizadas pelo IBGE, formam a categoria negros. Sendo assim, é possível se pensar aqui nessa alteração sobre qual o interesse dos legisladores incluir explicitamente a categoria pardos. Talvez a histórica exaltação à miscigenação e o mito da democracia racial expliquem algo nesse ponto.

Em 20 de novembro de 2008, a redação final foi assinada pelo relator, deputado Fernando Coruja (PPS/SC), e foi aprovada em plenário ${ }^{39}$, sendo remetida ao Senado Federal (a versão final da Câmara está disponível como anexo 1 desta dissertação). Passaremos, portanto, a análise do trâmite da matéria no Senado Federal.

\footnotetext{
${ }^{39}$ A Câmara dos Deputados disponibiliza arquivos de áudio da maior parte de suas sessões no seu arquivo de áudio, disponível em: <http://imagem.camara.gov.br/internet/audio/Resultado.asp?txtCodigo=32655>.
} 


\subsection{TRAMITAÇÃO DO PROJETO DE LEI NO SENADO FEDERAL}

PLC 180/2008 - Dispõe sobre o ingresso nas universidades federais e estaduais e nas instituições federais de ensino técnico nível médio e dá outras providências.

A matéria foi recebida no Senado Federal em novembro de 2008. No mesmo mês, foi despachada para as Comissões de Constituição, Justiça e Cidadania (CCJ); de Direitos Humanos e Legislação Participativa (CDH); e de Educação, Cultura e Esporte (CE). Na CCJ, a relatora designada foi a Senadora Serys Slhessarenko (PT/MT). Seu voto foi pela aprovação do projeto, porém, antes da votação na Comissão, foram realizadas três Audiências Públicas. As audiências públicas serão objeto de análise no próximo capítulo.

Tramitaram em conjunto o projeto de lei da Câmara (PLC) no 180/2008 (a proposta da Câmara dos Deputados ganha um novo número ao chegar no Senado) e o projeto de lei do Senado (PLS) nº 344/2008. O PLS nº 344/2008 apensado é de autoria do Senador Marconi Perillo (PSDB/GO) e há significativas diferenças entre sua proposta e a matéria em questão.

O projeto de lei do Senador Perillo (PSDB/GO) previa a reserva de vagas a estudantes que houvessem cursado os quatro últimos anos do ensino fundamental e todo o ensino médio em escolas públicas estaduais e municipais. O que se nota é uma maior exigência nas condições de ingresso tanto em relação à quantidade de tempo de estudos em escolas públicas, como no tipo de escolas públicas. Observe-se que estudantes que concluíram a educação básica em escolas públicas federais não poderiam concorrer às vagas reservadas.

O projeto do Senador (PSDB/GO) dispunha também sobre a gradualidade do instituto da reserva, propondo que a lei tivesse uma duração de doze anos, sendo que nos quatro primeiros 50\% das vagas seriam reservadas; nos quatro anos seguintes seriam $40 \%$ das vagas; e nos últimos quatro anos $30 \%$. Nesse sentido, observa-se uma diferença relevante em relação ao projeto de lei da Câmara, uma vez que o PLC n 180/2008 prevê que as vagas sejam gradativamente reservadas de modo crescente até $50 \%$ em um período de quatro anos e, em seguida, de acordo com o acompanhamento e avaliação da implementação da política. 
Aparentemente, a proposta principal em trâmite no Senado previa uma implementação de possível execução, em que, com o tempo, as instituições de ensino se adaptam, até o ponto em que se alcança a meta do número de vagas reservadas, e, então, se mantém a política por um período que seja suficiente para avaliar seus resultados. O projeto apensado, por outro lado, propunha que o início da política ocorresse com a reserva máxima de vagas e, sem previsão de acompanhamento e avaliação da política, já determinava em qual proporção seria diminuída a reserva de vagas. Essa diferença entre as propostas em trâmite no Senado Federal parece sintomática de que existiam propostas de política mais frágeis, que antes mesmo de acompanhar e avaliar já previa o término dela.

Outro ponto distinto da proposta do Senador Perillo (PSDB/GO) é que os estudantes que tivessem condições de concorrer às vagas reservadas de cada curso concorreriam entre si. E as instituições de ensino serão as responsáveis por definir qual seria o desempenho mínimo correspondente aos conhecimentos do ensino médio indispensáveis ao acompanhamento do curso pretendido.

Dois pontos de alerta se apresentam aqui: o primeiro é que nessa proposta as vagas reservadas seriam o teto, ou seja, os estudantes que fizessem jus às vagas, ao optarem pela seleção como cotistas, concorreriam com seus semelhantes. Ou seja, mesmo se tivessem nota suficiente para passar no sistema universal, ingressariam pelas cotas. Essa prática, na realidade, limita o acesso a uma porcentagem específica de pessoas, e a proposta original era exatamente o contrário, para garantir maiores possibilidades de ingresso. Ademais, ao se descentralizar e permitir que as instituições de ensino decidam sobre os conhecimentos necessários, os conteúdos das seleções ficam sujeitos à discricionariedade de cada instituição.

Ao analisar o projeto, a relatora Senadora Serys Slhessarenko (PT/MT) afirma: "O mérito de ambos os projetos é o de criar métodos de justiça social no ingresso nas escolas técnicas e instituições de ensino superior públicas ”. Contudo, afirma que dará mais atenção à análise do PLC n 180/2008, a proposta que veio da Câmara dos Deputados. A relatora afirma em seu parecer que a proposição segue os requisitos de constitucionalidade, juridicidade e boa técnica legislativa. Além disso, afirma que fará uma análise sobre o mérito socioeducacional da matéria, e, nesse sentido, produz uma análise bem completa da temática.

A relatora faz referência a dois então ministros do Supremo Tribunal Federal que já haviam se manifestado favoravelmente a questão das ações afirmativas, a Ministra Carmen Lúcia, que publicou um texto denominado "Ação Afirmativa: o conteúdo democrático do 
princípio da igualdade jurídica” e o Ministro Joaquim Barbosa que, também em publicação acadêmica, afirmou, segundo a relatora, que as ações afirmativas "são políticas públicas e privadas voltadas à concretização do princípio constitucional da igualdade material e à neutralização dos efeitos da discriminação racial, de gênero, de idade, de origem nacional e de compleição física”.

Além disso, chama a atenção o destaque dado nesse relatório ao histórico colonial do Brasil, ao período escravagista e à não ação estatal no sentido de reverter as desigualdades geradas. Citando a obra $O$ Abolicionista de Joaquim Nabuco, a relatora ressalta a centralidade que a educação tem em um processo de redução das desigualdades e de fomento ao desenvolvimento nacional. Afirma, também, que a superação das desigualdades entre negros e brancos seria o grande desafio republicano do início do século XXI.

O período pós-abolição da escravatura se constitui pela ausência de políticas públicas de integração dos ex-escravos e a população negra livre. Não obstante a isso, ainda se configurou pela adoção de iniciativas que contribuíram para que o horizonte verdadeiramente libertador dos ex-escravos ficasse restrito aos extratos sociais mais baixos. Isso possibilitou a consolidação de um racismo estrutural que se caracteriza pela manutenção de processos nefastos de exclusão que legaram aos negros uma trajetória inconclusa em relação à cidadania (Relatório senadora Serys Slhessarenko)

A relatora também faz referência às estatísticas que ilustram as desigualdades raciais, como por exemplo, as do mercado de trabalho, observando que negros possuem renda inferior, que a taxa de desocupação dos negros é maior e também que há sub-representação nas posições de maior qualificação; também nos dados educacionais, em que há taxas de analfabetismo maior entre os negros, bem como menor número de anos de estudos. Conforme o relatório, as informações foram extraídas de estudos do IPEA e também pelo Laboratório de Análises Econômicas, Sociais e Estatísticas das Relações Raciais (LAESER/UFRJ).

Outro ponto que deve ser destacado no relatório é o reconhecimento do impacto no país de eventos internacionais realizados pela Organização das Nações Unidas (ONU), como por exemplo, a Conferência de Durban, ocorrida em 2001, que desencadeou no Brasil uma quantidade maior de medidas de ações afirmativas. Há destaque no relatório a atuação do movimento negro nessa Conferência, que teve como reflexo de sua atuação uma profusão de propostas legislativas em prol desse tipo de política.

Além disso, o relatório destaca que a aprovação da proposta tenha ocorrido no dia 20 de novembro (Dia Nacional de Zumbi e da Consciência Negra) no Plenário da Câmara dos Deputados. E se opõe a algumas críticas feitas às ações afirmativas, como por exemplo, o não 
investimento na educação de base, afirmando que existem outros programas na área de educação que atendem a educação básica e que a proposta de ações afirmativas vem a complementar esse tipo de proposta para melhoria da educação; sobre a possibilidade desse tipo de política racializar as relações sociais no Brasil, afirmando que esse não costuma ser um efeito da política já aplicada em outros países; e, por fim, sobre a questão da autonomia universitária, ao afirma que o Supremo Tribunal Federal decidiu que ela não é irrestrita, ou seja, que essa autonomia é submetida à Constituição e outras normas gerais.

Sendo assim, o relatório conclui pela aprovação do PLC nº 180/2008, e pela rejeição do PLS n 344/2008, argumentando que o primeiro leva vantagem por haver sido amplamente debatido com a sociedade.

Em abril de 2009, houve novos requerimentos para tramitação conjunta com outras matérias. E a decisão da mesa diretora do senado foi pela tramitar em conjunto as seguintes matérias: PLC $n^{\circ}$ 180/2008; PLS no 215/2003; PLS n 344/2008 e PLS n 479/2008. A descrição dos projetos de lei que passaram a tramitar em conjunto segue abaixo:

PLC 180/2008, de autoria da Deputada Nice Lobão, que dispõe sobre o ingresso nas universidades federais e estaduais e nas instituições federais de ensino técnico de nível médio e dá outras providências.

PLS 215/2003, de autoria da senadora Íris de Araújo, que dispõe sobre a reserva de vagas nas universidades públicas para alunos carentes.

PLS 344/2008, de autoria do próprio senado Marconi Perillo, que institui a reserva de vagas nos cursos de graduação das instituições públicas de ensino fundamental e médio públicos.

PLS 479/2008, de autoria do senador Álvaro Dias, que reserva 20\% das vagas dos vestibulares para os cursos de graduação das universidades públicas federais e estaduais para estudantes oriundos de família com renda per capita familiar de até um salário mínimo e meio.

A senadora Serys Slhessarenko (PT/RS) seguiu sendo a relatora da proposição na CCJ e apresentou relatório, com voto pela aprovação do PLC $n^{\circ} 180 / 2008$ e pela rejeição dos PLS's 215/2003, 344/2008 e 479/2008, ficando assim pronta a proposta para votação da Comissão.

Em junho, o Senador Marconi Perillo (PSDB/GO) encaminhou voto em separado, com voto favorável ao PLC $n^{\circ} 180 / 2008$, nos termos da emenda substitutiva que apresentava e pela rejeição dos PLS's no 215/2003, no 344/2008 e no 479/2008. O voto em separado do Senador Marconi Perillo (PSDB/GO) apresenta algumas argumentações e informações interessantes de serem destacadas neste capítulo. 
Em sua análise das matérias, o Senador Perillo (PSDB/GO) inicia reconhecendo que não houve assistência nenhuma aos negros escravizados e que isso dificultou a integração social dessa parcela da população. Também aponta que a construção do mito da democracia racial fez com que o país durante décadas não se aceitasse como um país racista. Destacou que foi o governo de Fernando Henrique Cardoso o primeiro a expor oficialmente a existência do racismo no País e a pautar a criação de mecanismos de ações afirmativas nos moldes do que havia nos Estados Unidos.

\begin{abstract}
Realmente, ao final do processo de abolição, não houve qualquer mecanismo de integração dos afro-brasileiros à sociedade e, sem dúvida, estes foram extremamente prejudicados na ascensão e conquista de espaço no campo educacional e laboral. (...) Comparada a realidade norte-americana à brasileira, temos que reconhecer que, se não houve no Brasil uma verdadeira democracia racial, tampouco houve, entre nós, um processo de segregação nos moldes estadunidenses" (Voto em Separado do Senador Marconi Perillo)
\end{abstract}

E, nesse sentido, o relator passa a corroborar com os pensamentos de Sérgio Buarque de Holanda em Raízes do Brasil, em que se entende o colonizador português como um mestiço. O relator ressalta o processo de miscigenação foi marcante no país, “(...) tão logo aportou na terra brasilis, cuidou o colonizador ibérico de se mesclar, lubricamente, em as índias e, mais tarde, com as negras”. O senador Perillo (PSDB/GO) destaca, então, que esse processo de mestiçagem fez com que muitos brasileiros se identificassem como pardos.

A partir daí o senador afirma que se é necessário reconhecer o racismo, e também é importante compreender que, independentemente da cor, há exclusão social e pobreza. Argumenta que o negro das periferias do Norte, Nordeste e Sudeste não é menos excluído socialmente do que o branco pobre do Sul do país. "Na verdade, muitos brasileiros pobres são oriundos das massas de imigrantes europeus que vieram substituir a mão de obra escrava e foram também explorados em áreas urbano-industriais, mediante o sistema assalariado" (justificativa do Voto em Separado do Senador Marconi Perillo).

Fazendo uma breve análise do relatório do Senado, parece um pouco contraditório reconhecer que os negros não tiveram as mesmas condições de inserção social e, em seguida, dizer que brancos e negros pobres são igualmente excluídos. Na mesma medida em que parece, no mínimo, retórico dizer que há racismo no país e não considerar a questão racial como parte dos mecanismos de exclusão e pobreza.

Outro trecho que chama a atenção no voto do senador Perillo (PSDB/GO) é o seguinte: 


\begin{abstract}
A questão que se coloca na implementação de cotas não é se beneficiaremos os negros e afrodescendentes, mas, se ao agirmos somente sob o critério étnico e racial, não estaríamos ignorando a natureza da mestiçagem do povo brasileiro, e colocando à margem do benefício a população não negra igualmente excluída. Até Barack Obama, o primeiro Presidente negro dos Estados Unidos, já admitiu, em The Audacy of Hope, sua preferência por políticas universalistas às de recorte racial. (...) Por isso é que se o desejo do Estado brasileiro constituir na ruptura do ciclo de exclusão e pobreza, por meio do acesso ao ensino superior, haveremos que vislumbrar o critério social, de poder aquisitivo e indicadores socioeconômicos, por ser estes mais abrangentes e justos, quando comparado ao critério étnico e racial.
\end{abstract}

Esse trecho do relatório do senador Perillo (PSDB/GO) trata um dos pontos centrais da discussão, a questão: "E os brancos pobres?"40 Como nota-se, para ele, o debate sobre cotas é mais justo ao se considerar critérios socioeconômicos do que o critério racial.

Adiante no relatório, o senador afirma que, com a "Declaração Contra o Racismo" da Organização das Nações Unidas para a Educação, a Ciência e a Cultura (UNESCO), em 1950, há um consenso de que a luta contra o racismo exige esforços estatais para destruição da crença em raças. Sendo assim, o relator acredita que as cotas raciais caminham no sentido contrário à história. O senador ainda aponta algumas questões que estão em debate nas proposições analisadas, entre elas: a diferença antropológica entre raça e etnia; a problemática da autodeclaração; e a nomenclatura de cor de pele utilizada pelo IBGE.

De acordo com o relatório, o senador não acredita em um processo de racialização da sociedade brasileira causado pelas cotas, já que esse não é um fenômeno que foi observado em outros países onde houve a implementação de cotas. Essa parte do relatório parece em certa medida inconsistente, pois, poucos parágrafos antes, o relator afirma que não há no mundo experiências de cotas raciais, e sim de cotas étnicas e por castas. Então, se ele considera que não há no mundo cotas raciais, as experiências de outros países não têm como servir de referência para se pensar sobre a possível racialização ou não da sociedade brasileira.

Um outro ponto que merece ser destacado é a citação que o senador faz à participação de grupos representantes dos mestiços que estiveram presentes nas audiências públicas realizadas, como por exemplo o Movimento Nação Mestiça. Segundo ele, "mulatos", "cafuzos" e "caboclos" são comumente enquadrados na categoria pardos do IBGE, o que os representantes dos mestiços consideram um erro.

\footnotetext{
${ }^{40}$ Durante a banca de qualificação para a realização desse trabalho, o professor Mário Theodoro chamou a atenção para o tipo de discurso que era produzido pelas pessoas contrárias às cotas raciais para negros, principalmente questionando como ficariam os brancos pobres. Essa observação se confirma com a análise desse relatório.
} 
Nesse sentido, novamente analisando a proposta do senado Perillo (PSDB/GO), ele considera que as cotas sociais atendem com mais propriedade às necessidades da sociedade. Sua proposta é de que a porcentagem de vagas reservadas vá diminuindo gradativamente, pressupondo que o ensino público melhorará nesse período. Outro aspecto que o senador trata é a limitação da questão de renda, já que, de acordo com sua análise, a faixa salarial não seria um bom critério, uma vez que o custo de vida varia de acordo com cada localidade do país. A sua proposta é construída a partir da crença de que a disparidade de acesso ao ensino superior está diretamente relacionada à baixa qualidade do ensino público, por esta razão, seria importante que a reserva de vagas fosse destinada a estudantes que estudaram a maior parte da educação básica no ensino público.

Entendemos que o PLS 344/2008, ao propor a redução gradual do percentual das
vagas destinadas aos alunos oriundos de rede pública de ensino, obedece a premissa
de que, com o passar do tempo, haja melhoria no ensino público pátrio e, por
consequência, diminua a necessidade de reserva de cotas para ingresso nas
universidades. (...) o critério estabelecido no PLS $344 / 2008$ é mais adequado, já que
prevê a obrigatoriedade de o candidato ter cursado os últimos quatro anos do ensino
fundamental e todo o ensino médio em escolas públicas estaduais e municipais.

Conforme apresentado anteriormente, as propostas de modificações do projeto do senador Marconi Perillo (PSDB/GO), em resumo, foram: doze anos para implementação da lei; os estudantes aptos às vagas seriam aqueles que houvessem cursado quatro anos do ensino fundamental e todo ensino médio em escolas públicas; o percentual de vagas reservadas iria diminuindo a cada quatro anos; e as instituições seriam as responsáveis por definir os critérios mínimos de conteúdo para a avaliação.

A partir de 2010, o projeto passou a ser relatado na CCJ pela Senadora Ana Rita (PT/ES). Então, o PLC 180/2008 e os PLS's n 344/2008 e no 479/2008 continuaram a tramitar em conjunto. A relatora apresentou relatório que seguiu praticamente toda a argumentação da relatora anterior da matéria. Em sua análise, ela chega a fazer referências literais ao relatório não apreciado pela Comissão. Para analisar a constitucionalidade da matéria, a relatora reitera as citações da ministra do Supremo Tribunal Federal, Carmem Lúcia, e do jurista Celso Antônio Bandeira de Mello, que embasam a justificativa de constitucionalidade das ações afirmativas.

Nossa constituição respalda a adoção de medidas afirmativas como forma de romper com desigualdades solidificadas em nossa sociedade e que só poderão ser superadas com a atuação do Estado. A própria Constituição possui em seu texto exemplos, como a reserva de vagas em concursos públicos para pessoas com deficiência, insculpida no texto constitucional no inciso VIII do art. 37. (Relatório da Senadora Ana Rita) 
Desse modo, a relatora afirma que, quanto à constitucionalidade e à juridicidade, não há problemas nas proposições sob análise. Um ponto de destaque desse parecer é a forma explícita como é colocado que há consenso sobre a necessidade de cotas sociais, porém, ao se tratar das cotas raciais, não há acordo nas discussões parlamentares. Sendo que, apesar de se reconhecer que as condições de desvantagem sociais afetam majoritariamente as pessoas negras, a possibilidade de cotas exclusivamente raciais enfrentava muitas divergências.

A questão que demarca campos no debate em torno dessas proposições é a que diz
respeito à licitude ou não da desequiparação, para fins de promoçâo, com base em
elementos étnico-raciais. É bom lembrar que esse critério é secundário, em fase
daquilo que é o principal no discrímen positivo; a reserva de vagas para egressos de
escola pública. Neste ponto, cremos não haver divergências. (Relatório da Senadora
Ana Rita)

De forma análoga a relatora anterior, a senadora Ana Rita (PT/ES) cita dados do IPEA para apresentar as desigualdades existentes entre brancos e negros no Brasil. Informações sobre a baixa mobilidade social dos negros, a maior taxa de desocupação entre os negros, as taxas de rendimento menores entre a população negra em relação aos brancos e os poucos negros em posição de destaque na estrutura laboral são indicadores utilizados para justificar a necessidade das cotas. Note-se que, apesar de seu relatório apresentar informações sobre as desigualdades raciais, a senadora afirmou que há dúvidas e divergências sobre a necessidade das cotas raciais.

Em referência ao relatório da senadora Serys Slhessarenko (PT/RS), a relatora Ana Rita (PT/ES) ressalta que convenções internacionais tiveram um impacto importante no Brasil. E que não é verdade que as ações afirmativas seriam uma escusa para não se tratar o problema educacional a partir da base. Conforme o relatório, vários programas que visam a melhoria da educação como um todo estão sendo aplicados paralelamente, e que as ações afirmativas também compõem essa possibilidade de se tratar integralmente da educação.

Já ao final de seu relatório, a senadora informa que sua única alteração ao projeto em trâmite é a substituição do nome do Ministério responsável pelo acompanhamento, apenas por uma questão formal. A senadora Ana Rita (PT/ES) apresenta voto contrário aos PLS's no 344/2008, no 479/2008, e favorável ao PLC 180/2008, com uma emenda que apresenta. Em dezembro de 2011, o Senador Demóstenes Torres (DEM/GO) solicita realização de audiência pública para instrução da matéria, que não foi realizada.

Em maio de 2012, foi concedida vistas aos Senadores Lobão Filho (PMDB/MA), Luiz Henrique (PMDB/SC), Eduardo Suplicy (PT/SP), Marta Suplicy (PT/SP) e Francisco 
Dornelles (PP/RJ), nos termos regimentais. Em junho de 2012, foi apresentado o Voto em Separado de autoria do Senador Lobão Filho (PMDB/MA), que conclui pela aprovação do PLC 180/2008, nos termos da emenda substitutiva que apresenta, e pela rejeição dos PLS $344 / 2008$ e 479/2008.

O voto em separado do senador Lobão Filho (PMDB/MA), apesar de não ter sido aprovado na Comissão, traz algumas informações relevantes para se compreender esse processo de conflito e disputa em torno das ações afirmativas no Senado Federal, em especial na CCJ. Como seu relatório é bastante objetivo e explicita claramente quais são seus pontos de discordância em relação à matéria em tramitação, será possível descrever exatamente o posicionamento do senador.

O primeiro ponto de discordância apresentado na análise do relatório é sobre as cotas raciais. Esse documento é o primeiro ao longo do percurso legislativo que coloca com evidência o debate das cotas raciais versus cotas sociais. Até esse momento, esse embate estava em pauta, porém estava sendo dito em outros termos. Nesse voto em separado, o senador Lobão Filho (PMDB/MA) apresenta seu posicionamento contrário às cotas raciais e sua preferência pela implementação das cotas sociais.

No que se refere às chamadas 'cotas raciais', embora tenhamos consciência de que o Supremo Tribunal Federal as considerou em acordo com a Constituição, somos da convicção de que preferencialmente devemos adotar sistema de 'cotas sociais', que permite e favorece o acesso à educação superior e técnica de todos os brasileiros que tenham cursado o ensino médio e fundamental nas escolas públicas, em especial àqueles oriundos de famílias com baixa renda. (Voto em Separado do Senador Lobão Filho)

Conforme análise do senador, não há antagonismo entre cotas raciais e cotas sociais, pelo contrário, os beneficiários das cotas raciais seriam aqueles mais pobres e estudantes de escolas públicas que, como comprovam os dados estatísticos, são parcelas da população compostas por negros. A principal justificativa para que ele entenda as cotas sociais como preferíveis, no relatório, foi: “As cotas sociais permitem alcançar os mesmos objetivos das cotas raciais, sem ricos de uma perigosa divisão da sociedade brasileira contidos nessas últimas".

Ou seja, aparentemente, o senador Lobão Filho (PMDB/MA) considerava que os resultados a serem alcançados pelos dois tipos de cotas seriam semelhantes, sendo que a vantagem das cotas sociais seria a não divisão ou racialização do país. Intrigante notar como a problemática de exclusão da população negra está fora de questão para esse parlamentar, 
nessa matéria; bem como não é utilizada nenhuma fonte de pesquisa e nenhuma referência estatística de fato para se tratar dos dados de desigualdade, seja ela incluindo a questão racial ou não.

Outro ponto que o senador Lobão Filho (PMDB/MA) propõe modificação é sobre a origem dos estudantes beneficiários das cotas, aproximando-se da proposta do senador Marconi Perillo (PSDB/GO). Sua ideia é a de que os estudantes tenham cursado pelo menos quatro anos do ensino fundamental em escola pública. Por fim, destaca que considera mais adequado privilegiar as formas de seleção já vigentes e manter e fortalecer os vestibulares e o ENEM (Exame Nacional do Ensino Médio), que, conforme o senador, preservam os critérios de impessoalidade e mérito. Esses foram os pontos principais do voto em separado do senador Lobão Filho (PMDB/MA).

Em junho de 2012, durante a discussão da matéria na Comissão, o senador Aloysio Nunes Ferreira (PSDB/SP) apresenta Voto em Separado que conclui pela aprovação do PLS 479/2008 com a emenda por ele apresentada e pela rejeição do PLC 180/2008 e do PLS $344 / 2008$.

Consideramos importante apresentar também o teor do projeto de lei apoiado pelo senador Aloysio Nunes (PSDB/SP), bem como sua justificativa à matéria. O PLS 479/2008 foi apresentado pelo senador Álvaro Dias (PSDB/PR), e sua ementa prevê a "reserva 20\% das vagas dos vestibulares para os cursos de graduação das universidades públicas federais e estaduais para estudantes oriundos de família com renda per capita familiar de até um salário mínimo e meio".

$\mathrm{O}$ voto em separado do senador Aloysio Nunes (PSDB/SP) reforça o argumento apresentado no parágrafo $2^{\circ}$ do PLS n ${ }^{\circ} 479 / 2008$, que afirma que essa proposição "não admite nenhum tipo de privilégio ou discriminação relativa a cor, gênero, credo religioso ou posição política”. Ao realizar a análise em seu relatório, o senador faz menção ao julgamento do STF em relação à constitucionalidade das cotas na Universidade de Brasília.

De acordo com seu relatório, os ministros da suprema corte estavam julgando um caso específico, porém, preferiram unanimemente avançar na discussão do mérito das cotas raciais e das ações afirmativas, consagrando-as como coerentes com os valores e princípios da Constituição Federal. O senador afirma que não se pode confundir a decisão do STF com os 
projetos legislativos em andamento no Senado Federal por se tratarem de uma lei distinta que se propunha a ser um marco regulatório na implementação das cotas.

Em seu relatório, o senador se manifesta contrariamente ao Coeficiente de Rendimento previsto nas outras proposições em trâmite, por ser um mecanismo que desprestigiaria a escola pública de qualidade. $\mathrm{O}$ senador argumenta em favor do vestibular, afirmando ser esse um mecanismo que afere mérito e qualidade da formação dos concorrentes.

Ao tratar da discussão cotas raciais versus cotas sociais, que neste momento estava claramente colocada o relatório do senador, afirma:

(...) se o que deve ser buscado é a superação de 'distorções historicamente consolidadas', não cremos que o critério racial seja a melhor solução. Se tais distorções são o fruto de condições estruturais extremamente desfavoráveis aos negros (o que não negamos de forma alguma), há de se concordar que a situação de exclusão e dificuldade de acesso ao ensino superior dos brancos pobres (oriundos da escola pública e do mesmo nível de renda) não é diferente. Assim, a proposta de seleção por raça ou cor, a pretexto de gerar uma justiça distributiva e compensatória, certamente produzirá injustiça para quem hoje, independentemente das razões, se encontra na mesma situação de exclusão dos negros e pardos a quem se busca recompensar. (...) Por outro lado, não estamos convencidos de que fazer o corte por raça seja menos favorável ao negro pobre do que um corte por renda, somada à condição de escola pública. Sendo verdade que a população negra é pobre e estuda na escola pública, não há aparente razão, para duvidar de que o resultado da seleção por nível de renda e a pré-condição de origem na escola pública não traga os mesmos ou até melhores resultados do que o corte por raça, com a vantagem de não gerar a exclusão do branco pobre. (Voto em Separado do senador Aloysio Nunes)

Analisando esse relatório, nota-se que não há nenhuma citação à fonte de pesquisa que sustente as afirmações feitas pelo senador. A única breve referência feita no texto é ao livro de Ali Kamel, Não Somos Racistas. O relatório tem trechos exatamente iguais aos presentes no relatório do senador Marconi Perillo (PSDB/GO) e já citados anteriormente. Como observa-se, a preocupação prioritária da argumentação do senador Aloysio Nunes (PSDB/SP) é com o grupo de brancos pobres.

Não é um requisito aos relatórios dos projetos de lei a apresentação de fontes ou de critérios de citação e referência rígidos como os que são seguidos cientificamente. No entanto, seria muito interessante que a argumentação do segundo parágrafo do relatório aqui destacado apresentasse suas fontes, uma vez que informações difundidas por alguns centros de pesquisa do país afirmam justamente o oposto. Ou seja, seleções que priorizam o critério social geralmente admitem uma proporção de estudantes brancos bastante superior à proporção de 
estudantes negros, sendo possível concluir que há fatores (raça/gênero), para além da renda, que influem nos resultados desses processos seletivos ${ }^{41}$.

Para os fins da análise aqui proposta é importante apresentar brevemente os argumentos expostos na justificativa do PLS n ${ }^{\circ}$ 479/2008 pelo autor senador Álvaro Dias (PSDB/PR). Esse projeto conta com apenas dois artigos já referidos anteriormente: um que estipula uma porcentagem menor de vagas reservadas (20\%) e outro que afirma não se admitir nenhum tipo de privilégio. A justificativa da proposta é basicamente um resumo de um artigo publicado por Ali Kamel em um artigo do jornal $O$ Globo, que condensa as discussões sobre cotas em três correntes.

\begin{abstract}
A primeira corrente entende que o racismo no Brasil é responsável pela desigualdade entre negros, pardos e brancos, por isso defende cotas raciais puras, sem corte de renda. Para a segunda corrente o racismo existe, em maior ou menor grau, em todas as sociedades. No entanto, a principal causa da desigualdade é a pobreza. Negros e pardos estão em pior situação, pois são a maioria entre os pobres. Já a terceira corrente acredita que a pobreza é o principal fator de explicação da desigualdade, por isso defende a adoção de políticas sociais para os pobres em geral, focando os investimentos em educação básica. Esta corrente é contrária à adoção de cotas. Em seu artigo, Ali Kamel argumenta que o projeto de cotas aprovado pela Câmara dos Deputados e encaminhado ao Senado Federal mistura conceitos de raça e renda, além de reservar um percentual muito grande (50\%) das vagas dos vestibulares. (Justificativa do PLS 479/2008 do senador Álvaro Dias)
\end{abstract}

Então, segundo o autor, o projeto de lei em trâmite desagrada a todas elas. Primeiro, por excluir os negros não pobres, a segunda por excluir os brancos pobres e a terceira por estabelecer cotas. Nesse sentido, ele acredita ser necessário o fortalecimento da educação básica e a não existência de cotas. Porém, como as cotas estão sendo necessárias, ele propõe a admissão de cotas sociais para redução de desigualdades sociais.

A Comissão aprovou o Relatório da Senadora Ana Rita (PT/ES), que foi favorável ao PLC 180/2008 e contrária aos PLS no 344/2008 e no 479/2008. Foram votos vencidos os Senadores Aloysio Nunes Ferreira (PSDB/SP), Lobão Filho (PMDB/MA), Álvaro Dias (PSDB/PR) e Luiz Henrique (PMDB/SC). Ficaram prejudicados os votos em separado dos Senadores Lobão Filho (PMDB/MA) e Aloysio Nunes Ferreira (PSDB/SP).

Em junho de 2012, a matéria foi encaminhada à Comissão de Direitos Humanos e Legislação Participativa (CDH). A matéria foi avocada pelo Presidente da Comissão, senador

\footnotetext{
${ }^{41} \mathrm{O}$ texto Ação afirmativa, raça e racismo: uma análise das ações de inclusão racial nos mandatos de Lula e Dilma, publicado em 2012, afirma que experiências da Universidade Estadual do Norte Fluminense Darcy Ribeiro e da Universidade Estadual do Rio de Janeiro demonstraram declínio brutal do ingresso de negros a partir do momento em que foram utilizados critérios sociais e étnico-raciais combinados. Disponível em: <http://www.cch.ufv.br/revista/pdfs/vol12/artigo8vol12-2.pdf>.
} 
Paulo Paim (PT/RS). Esse senador apresentou seu relatório, concluindo pela aprovação do PLC 180/2008 com as emendas da CCJ e mais duas que ele apresenta; concluindo pela rejeição dos PLS nº 344/2008 e nº 479/2008.

O relatório do senador é sucinto e direto. O senador informa o conteúdo das propostas sob análise, que já foram anteriormente expostas neste capítulo. E retoma a decisão da Comissão anterior que foi pela constitucionalidade da matéria. Duas emendas foram aprovadas, contudo nenhuma alterou o mérito da proposição. A senadora Ana Rita (PT/ES) propôs a emenda que atualizou o nome do Ministério da Educação, e o senador Aloysio Nunes (PSDB/SP) propôs a emenda que suprimiu a expressão "e estaduais" da ementa.

Em sua análise da matéria, o relator destacou as competências da $\mathrm{CDH}$, a que cabe opinar sobre a garantia e a proteção dos direitos humanos; e, também, sobre a proteção à juventude. Ressaltou o papel da educação na promoção do exercício da cidadania, bem como na melhora da qualidade de vida.

\footnotetext{
Por meio da sistematização dos conhecimentos, a educação é, sim, instrumento de promoção da igualdade, multiplicadora de ações protetivas dos jovens, e promotora dos direitos humanos. De fato, os espaços universitário e técnico configuram ambientes de socialização; locais de aquisição de conhecimentos e informações especializadas; espaços de promoção do amadurecimento educacional. (Relatório Senador Paulo Paim)
}

Nesse sentido, o senador considerou justa a proposta de estabelecimento de ações afirmativas na educação superior e técnica do país. Apontou como necessária a substituição do termo negro por preto, seguindo as próprias categorias do IBGE. Explicou que a população negra engloba pretos e pardos, e que apesar das críticas e discussões em torno dessas categorias, elas possuem um papel legitimador das representações étnicas e raciais do Brasil.

A CDH votou e emitiu parecer pela rejeição dos PLS no 344/2008 e PLS nº 479/2008, pela aprovação do PLC n ${ }^{\circ} 180$ de 2008 e emendas. Em julho de 2012, é proferido pelo Senador Paulo Paim (PT/RS), relator designado em substituição na Comissão de Educação, Cultura e Esporte, parecer de Plenário concluindo nos mesmos termos do parecer proferido pelo senador na CDH. Usam da palavra os Senadores Aloysio Nunes Ferreira (PSDB/SP), Paulo Paim (PT/RS) e Wellington Dias (PT/PI).

Em agosto, após usarem da palavra os Senadores Aloysio Nunes Ferreira (PSDB/SP), Ana Rita (PT/ES), Paulo Paim (PT/RS) e Pedro Taques (PDT/MT), aprova-se o projeto, ressalvadas as emendas e com o voto contrário do Senador Aloysio Nunes Ferreira 
(PSDB/SP). Aprovadas as emendas de redação, ficam prejudicados os PLS no 344/2008 e PLS no 479/2008, que tramitavam em conjunto. E, por fim, é aprovada a redação final da matéria e remetida à sanção presidencial ${ }^{42}$.

A Lei de Cotas foi sancionada pela presidenta Dilma Rousseff em 29 de agosto de 2012 e, em seguida, foi regulamentada pelo Ministério da Educação por meio da Portaria Normativa $\mathrm{n}^{\mathrm{o}} 18$ de 15 de outubro de 2012, no mesmo dia em que foram disponibilizadas informações complementares sobre a lei ${ }^{43}$. A partir da regulamentação pelo MEC, as instituições educacionais passaram a implementar a reserva de vagas em seus processos seletivos. A previsão inicial era a de que, a cada ano, no mínimo 12,5\% da reserva de vagas fosse implementada, até que, em quatro anos, $50 \%$ das vagas disponíveis se destinassem a cotas. De acordo com o site do Ministério da Educação, em 2013, o percentual de vagas para cotistas foi de 33\%, índice que aumentou para $40 \%$ em 2014, havendo previsão de cumprimento da reserva de $50 \%$ para $2016^{44}$.

\subsection{CONSIDERAÇÕES FINAIS SOBRE A TRAMITAÇÃO LEGISLATIVA DA LEI DE COTAS}

Conforme já exposto, a questão central que norteia esta investigação é: Como se formou a Lei de Cotas (Lei $n^{\circ}$ 12.711/2012)? Buscando respostas, entendeu-se que a análise da tramitação legislativa poderia oferecer importantes direções para a compreensão desse processo. Sabe-se que estudos sociais não são capazes de abarcar a totalidade dos fatores que compõem os processos sócio-políticos ${ }^{45}$, contudo, é possível a partir deles identificar alguns fatores relevantes e estabelecer conexões causais que expliquem a realidade atual. Esse foi o intento deste capítulo.

A existência da Lei Cotas coloca as discussões sobre ações afirmativas no Brasil em uma nova era. Se na década de 1990 ocorriam discussões sobre a viabilidade da implementação dessas políticas, e essa era apenas uma possibilidade distante e discursiva, na

\footnotetext{
${ }^{42}$ A versão final aprovada no Senado está disponível como anexo 2 desta dissertação.

${ }^{43}$ Fonte: notícia do site do Ministério da Educação intitulada Lei de Cotas é regulamentada e portaria esclarece a aplicação. Disponível em: <http://portal.mec.gov.br/ultimas-noticias/212-educacao-superior1690610854/18150-lei-de-cotas-e-regulamentada-e-portaria-esclarece-a-aplicacao >. Acesso em 21 dez. 2016.

${ }^{44}$ Fonte: notícia do site do Ministério da Educação intitulada "Em três anos, Lei de cotas tem metas atingidas antes do prazo". Disponível em: <http://portal.mec.gov.br/ultimas-noticias/212-educacao-superior1690610854/30301-em-tres-anos-lei-de-cotas-tem-metas-atingidas-antes-do-prazo> Acesso em 21 dez. 2016.

${ }^{45} \mathrm{Em}$ A 'objetividade' do conhecimento nas ciências sociais, Max Weber, afirma '(...) nem se quer se pode pensar a mera descrição exaustiva do mais ínfimo fragmento da realidade. Pois o número e a natureza das causas que determinaram qualquer acontecimento individual são sempre infinitos (...)” (WEBER, 1989, p. 94).
} 
primeira década dos anos 2000 nota-se a difusão de modelos de ações afirmativas sendo implementados em todo o país, passando da ideia e do plano discursivo para a prática e o experimento. A partir de 2012, com a nova normativa, passa a existir um padrão de modelo das cotas pelo país. A regulamentação federal cria um sistema homogeneizante de reserva de vagas nas instituições de ensino federais, e passa a servir de referência para as instituições estaduais e municipais.

Como consequência, vive-se atualmente no país um novo momento em relação ao ingresso no ensino superior público que, entre outros fatores, tem na Lei de Cotas uma proposta de modificar estruturalmente as características dos ingressantes. Compreender como se deu o processo sócio-político de construção da Lei de Cotas possibilita identificar os atores, as organizações sociais, os discursos convergentes, os conflitos e as disputas políticas presentes. A identificação desses elementos auxilia na compreensão de questões um pouco mais abrangentes da sociedade brasileira, como por exemplo, o funcionamento do racismo institucional, a resistência do mito da democracia racial e a deficiência na representação política da população negra.

\subsubsection{Divergências analíticas sobre o modelo de Lei formulado}

Alguns estudos recentes sobre ações afirmativas têm discutido o formato da Lei de Cotas e seus possíveis impactos na educação superior brasileira. Há divergências que têm se destacado nessas análises. Se, por um lado, há pesquisadores que consideram a atual legislação um freio aos avanços que estavam sendo alcançados, argumentando que ela simplifica as necessidades e não contempla as complexidades locais, por outro lado há estudiosos que consideram a legislação vigente um avanço no debate, que deve ser comemorado e monitorado.

Sales dos Santos (2015) argumenta que:

Segundo o nosso entendimento, o que a Lei 12.711/2012 fez foi desvirtuar o objetivo das políticas de ações afirmativas, visando transformá-las em políticas de combate à pobreza, ou seja, orientadas pelo recorte da classe social ou da renda. É evidente e inquestionável que no Brasil raça e classe se entrecruzam. Mas pensamos, em face da complexidade das relações sociais, que variável raça não pode ser reduzida e/ou subsumida na classe social, como estão tentando fazer os defensores da Lei de Cotas. (op.cit., p.94). 
Renato Ferreira (2013), em análise sobre as políticas de promoção da igualdade racial, em específico sobre a Lei de Cotas, afirma:

Com essa lei, cotas serão reservadas - só nas universidades federais, cerca de 50 mil vagas para negros e indígenas por ano -, dado o caráter inclusivo e redistributivo da política. Isso trará um grande impacto social para as instituições federais de educação e será determinante para diversificar a elite brasileira nas próximas gerações. Tudo nos leva a reconhecer que se trata de um importante programa que, somado ao Prouni, ao programa Reestruturação e Expansão das Universidades Federais (Reuni) e ao Programa Nacional de Acesso ao Ensino Técnico e Emprego (Pronatec), completa uma série de políticas que vêm sendo adotadas nos últimos anos para tornar mais democrático o direito à educação no Brasil (op.cit., p. 374).

José Jorge de Carvalho (2013) afirma em entrevista ${ }^{46}$ :

Das 51 universidades federais que tem cotas, 46 tem modelo diferente. Cada universidade que aprovou procurou fazer de forma diferente das anteriores. Foi resultado sempre de uma negociação por parte dos Conselhos [Universitários]. Uma variedade de sistemas. A Lei 12711/2012 simplifica o raciocínio. A massa crítica que gerou a luta pelas ações afirmativas não pôde influenciar o Congresso. Todas as audiências foram inúteis, foram inférteis, dissociadas de reflexão. Toda a inteligência gerada pela sociedade foi desprezada, considerada irrelevante.

Dilvo Ristoff (2012) argumenta que:

(...) temos de celebrar a Lei de Cotas (Lei 12.711/2012), pois só com políticas que combinem expansão com democratização será possível fazer com que o campus deixe de ser um espelho que distorce e passe a promover a igualdade de oportunidade para todos. Dizer que o campus apenas reflete a sociedade equivale a lhe atribuir um papel passivo que ele não tem e a retirar dele o papel de agente capaz de interferir de um modo mais desejável na realidade existente." (op.cit., p. 10) ${ }^{47}$.

Seria possível elencar várias outras manifestações favoráveis e contrárias ao formato final da lei. Esse trabalho não pretende aprofundar essa discussão, uma vez que, com a Lei aprovada, regulamentada e em pleno processo de implementação, nos parece mais frutífero buscar compreender como esse modelo foi formado. Vale considerar também que a análise da construção de uma política pode auxiliar na compreensão de sua implementação.

A Lei de Cotas parece ser um complexo arranjo institucional que pretende acomodar algumas forças sociais em disputa. Esse modelo avança na medida em que se democratiza o acesso ao ensino superior público no país, porém, seu formato e sua tramitação legislativa demonstram quais questões se sobressaíram na discussão e como o critério racial, central no debate, foi marginalizado e posto dentro do critério social.

\footnotetext{
${ }^{46}$ Disponível em: <http://www.carosamigos.com.br/index.php/cotidiano/2276-professor-da-unb-diz-que-lei-dascotas-e-um-retrocesso>. Acesso em 22 dez. 2016.

${ }^{47} \mathrm{O}$ Movimento dos Sem Universidade publicou também um manifesto celebrando a legislação aprovada, a íntegra desse manifesto está disponível no anexo 3 desta dissertação.
} 
Conforme foi possível notar na tramitação legislativa, o ponto central de divergência entre os congressistas era a decisão sobre o embate entre cotas raciais versus cotas sociais. Observa-se que havia significativo apoio às cotas sociais, enquanto às cotas raciais desde o início foram colocadas em questão. E esse fato nos parece revelador ao se pensar as relações de poder e as relações raciais no país.

A seguir, analisaremos de modo global a tramitação legislativa, destacando os pontos principais e apresentando algumas das possíveis reflexões a partir dessa realidade.

\subsubsection{Destaques da tramitação legislativa}

Ao se analisar a tramitação de uma matéria no Legislativo brasileiro, é indispensável considerar a centralidade do Poder Executivo na produção legislativa do país. Estudos recentes têm demonstrado que a Constituição de 1988 coloca em desequilíbrio algumas atribuições dos Poderes, entre elas está a capacidade do Executivo de propor as medidas provisórias que tem trâmite legislativo mais célere, por exemplo. Além disso, o Poder Executivo tem enorme capacidade de influenciar a agenda do Congresso Nacional, e, no caso da Lei de Cotas, essa realidade também foi observada.

A partir da apresentação do projeto de lei de autoria do Executivo, o PL no 73/1999 passou a ter andamento de fato na Câmara dos Deputados. Nos cinco primeiros anos desde a sua apresentação, a proposição não chegou nem a ser apreciada pela primeira Comissão. A partir de 2004, com a apresentação do projeto do governo, parlamentares petistas passaram a assumir a relatoria da matéria e seu andamento se deu de modo mais célere nas casas legislativas.

Esse estudo permite afirmar que foi na Câmara dos Deputados que o projeto de lei ganhou o formato que a Lei de Cotas possui hoje. Os três critérios de seleção ${ }^{48}$, por exemplo, foram decididos no âmbito da Câmara dos Deputados. O projeto enviado pelo Poder Executivo previa que as cotas raciais estivessem condicionadas ao pertencimento à escola pública; ao que tudo indica esse formato foi construído com inspiração na Lei do PROUNI.

\footnotetext{
48 1) Ser de escola pública, 2) renda familiar e 3) critério étnico-racial.
} 
De acordo com as entrevistas realizadas para este trabalho, sabe-se que o Ministério da Educação não tinha convicção sobre as cotas raciais. O empenho do governo foi na busca pela aprovação das cotas sociais. Nota-se pela tramitação que, desde o início, os parlamentares petistas construíram a narrativa de que há maior racionalidade nas cotas combinadas do que nas cotas exclusivamente raciais.

As discussões do plenário da Câmara dos Deputados incorporaram o critério de renda familiar máxima (1,5 salário mínimo) à proposta, levando a questão racial a um patamar ainda menor. O acréscimo de mais um critério indicador de renda fez com que o debate racial quase não coubesse na proposta. Arrisco afirmar que sua manutenção se deu pela forte pressão e expectativa do movimento negro sobre o tema.

A chegada da proposição ao Senado também mobiliza alguns esforços e articulações políticas. Como nota-se pela tramitação, a matéria teve dificuldade para sair da primeira comissão, a Comissão de Constituição e Justiça. Nela, foram realizadas três Audiências Públicas, foram feitos e concedidos alguns pedidos de vista e foram apresentados votos em separado. Todas essas ações apontam para a existência de resistência na aprovação do projeto de lei.

Destaca-se na análise documental da tramitação no Senado o conteúdo dos votos em separado. Assim como exaustivamente descrito neste capítulo, os Senadores apresentaram proposições que excluíam completamente o critério racial e que constituíam um modelo de política bastante frágil. Portanto, a alternativa política apresentada por alguns senadores desconsiderava toda a discussão racial relacionado às ações afirmativas.

As divergências analíticas colocadas no tópico anterior demonstram que um modelo de lei melhor poderia ter sido formulado, caso os parlamentares se inspirassem em experiências que já existiam e já possuíam avaliações. Porém, ao se analisar a tramitação no Senado Federal, fica evidente o áspero cenário para a existência de um outro formato de lei. Considerando a reflexão sobre relações raciais que esse trabalho pretende fazer, nota-se que as propostas alternativas apresentadas eram menos favoráveis à redução das desigualdades raciais.

São os documentos do Senado que apresentam com grande evidência onde estava o ponto central de embates e conflitos: nas cotas raciais. Aparentemente, mesmo com dados e indicadores de desigualdades raciais; ainda que os senadores reconhecessem discursivamente 
que os prejuízos da escravidão não foram reparados; mesmo com a decisão do STF pela constitucionalidade das cotas tal como implementadas na UnB; ainda assim, não havia concordância sobre a necessidade das cotas raciais.

Nesse contexto, o que se observa é que o trâmite nas duas últimas Comissões do Senado se deu de modo acelerado. O senador Paulo Paim (PT/RS), como já mencionado, é um dos principais articuladores da temática racial no Congresso Nacional, e foi o responsável pela relatoria da proposição nas duas Comissões. É possível notar que a estratégia política utilizada por ele e pelos demais agentes políticos engajados na aprovação do projeto foi a de garantir que nenhum retrocesso fosse incorporado à proposta, encaminhando as discussões e votações com mais rapidez.

E assim foi o fim da tramitação no Senado, e, sem modificações no conteúdo, a matéria seguiria direto para sanção presidencial, não sendo necessária nova apreciação da Câmara dos Deputados. No plenário do Senado ocorreram discussões intensas, e, inclusive, foram aplicadas estratégias para que a matéria não fosse colocada em votação. $\mathrm{O}$ senador Aloysio Nunes protagonizou a oposição forte à proposição.

A aprovação da matéria, provavelmente, deixa um gosto amargo de uma vitória com as alianças desfavoráveis. Regulamentada a Lei de Cotas, a legislação está em período de implementação, e algumas análises sobre seu impacto já começaram a ser desenvolvidas. Vários novos desafios se colocam, e o acompanhamento e avaliação de políticas públicas no Brasil sofre com algumas limitações dada a escassez ou inacessibilidade dos dados, dificuldade percebida também para o caso da Lei de Cotas. Assim como exposto pelo INEP em 2016, há subnotificação do quesito cor/raça de discentes e docentes no Censo da Educação Superior, o que impacta nas possibilidades de acompanhamento, monitoramento e avaliação da política ${ }^{49}$.

A descrição e a análise desse trâmite legislativo suscita uma infinidade de questões a serem problematizadas. Entre elas, três pontos parecem especialmente importantes: o racismo institucional, o mito da democracia racial e a deficiência de representação política negra. Seguramente cada uma dessas categorias é bem mais abrangente do que será possível se desenvolver nesse trabalho, entretanto compreender o processo aqui estudado com auxílio

\footnotetext{
49 Texto publicado em 2016, denominado A cor ou raça nas estatísticas educacionais_ uma análise dos $\begin{array}{llllll}\text { instrumentos de } & \text { pesquisa } & \text { do } & \text { INEP. } & \text { Disponível } & \text { em: }\end{array}$ <http://www.publicacoes.inep.gov.br/portal/download/1601>. Acesso em 25 fev. 2017.
} 
delas parece fundamental. O capítulo conclusivo tratará com mais profundidade sobre os significados e as relações possíveis entre estas categorias. Por ora, em linhas gerais, aqui podemos afirmar que a tramitação legislativa desse tema parece evidenciar como se dá um processo de racismo institucional. Na medida em que a justificativa mais comumente debatida nas últimas décadas para implementação de cotas para ingresso nas universidades esteve centrada nas desigualdades raciais, a incorporação marginal do tema na proposição ilustra a maneira como as questões raciais são tratadas nas instâncias de poder do país.

Além disso, os documentos produzidos nesse processo de construção da Lei demonstram como o mito da democracia racial ainda embasa e legitima a argumentação dos parlamentares. A crença em que uma divisão racial se daria a partir do momento em que as cotas raciais fossem admitidas; o apego à crença de que as pessoas de raças diferentes vivem harmonicamente no país; e a valorização da miscigenação como um patrimônio nacional, todos estes argumentos reificam o mito da democracia racial. Ousaria dizer que essa crença na democracia racial constitui um dos pilares do racismo institucional brasileiro.

A terceira questão, a representação política dos negros, conecta-se ao debate que iniciou esse capítulo - a democracia. Se é verdade que o mundo vive uma crise de representação política, essa crise parece colocar-se de modo especialmente grave no caso da representação da população negra no Brasil. Mesmo sendo mais da metade da população, menos de $10 \%$ dos parlamentares no Congresso Nacional atualmente são negros. O reduzido percentual de negros em cargos eletivos complexifica a discussão sobre uma decisão política como a estudada nesse trabalho.

Evidentemente não é possível fazer uma ligação direta entre a cor do parlamentar e sua atuação política, essa seria uma essencialização incabível. Também, não é possível desconsiderar a atuação de parlamentares brancos em causas raciais, alguns possuem sim sensibilidade ao tema. No entanto, me parece que a vivência na própria pele do racismo pode ser um fator motriz da atuação política engajada, assim como nota-se em parlamentares como Benedita da Silva (PT/RJ) e Paulo Paim (PT/ES).

Essas três questões, extraídas de reflexões sobre a tramitação da Lei, se conectam e serão aprofundadas posteriormente neste trabalho. Entendendo que no debate sobre as desigualdades raciais no Brasil as cotas apareceram como uma alternativa política viável, esperava-se que as discussões no Legislativo fossem reflexo disso. Contudo, o que se notou 
foi a discussão das cotas priorizando critérios de classe social e formando um modelo de lei em que as cotas raciais estão subsumidas às cotas sociais.

Então, os parlamentares, os detentores do poder de decisão, não foram convencidos sobre a necessidade das cotas raciais. Ao observarmos os documentos disponíveis na tramitação legislativa, é perceptível que esse tema foi constantemente discutido e, ao mesmo tempo, foi tratado marginalmente na incorporação à norma.

O próximo capítulo será dedicado à análise das Audiências Públicas que aconteceram no Congresso Nacional no período de tramitação do projeto de lei. Esta análise busca evidenciar os momentos de interlocução entre a sociedade civil e o Estado contidos nas audiências públicas. Nestes momentos, a discussão racial foi tratada com a centralidade que estava sendo pautada nas discussões em outros espaços sociais. 


\section{CAPÍTULO 3 \\ AUDIÊNCIAS PÚBLICAS SOBRE COTAS NO CONGRESSO NACIONAL}

O capítulo anterior apresentou o contexto político do período de formação da Lei de Cotas, bem como detalhou o trâmite legislativo por meio de análise dos documentos disponíveis. A partir disso, foi possível notar que, se por um lado a discussão sobre ações afirmativas no Brasil difundiu-se muito por ser uma possibilidade política para inclusão racial; por outro, no momento de se produzir a norma em si, a questão racial foi o ponto mais conflituoso da proposta, sendo ao final colocada à margem da legislação vigente.

A Lei de Cotas atual possui inegável potencial para ser um instrumento de democratização do ensino superior. Esse trabalho entende que, em relação à forma de seleção que existia até essa Lei, o que está previsto nela é um avanço. No entanto, a discussão que se propõe neste capítulo diz respeito ao debate racial na formulação da normativa. Ou seja, se é verdade que a questão racial era central nas discussões acadêmicas, jurídicas e midiáticas a respeito das ações afirmativas pelo menos nos últimos vinte anos, por que a Lei trata marginalmente desse ponto?

Racismo institucional parece ser um bom conceito na busca por explicar o que aconteceu no trâmite legislativo dessa matéria. Este terceiro capítulo buscará compreender o processo de formação da Lei por meio de outro tipo de técnica e material de pesquisa. Com base nas notas taquigráficas dos discursos proferidos nas Audiências Públicas será feita uma análise de conteúdo. Os dados a serem apresentados neste capítulo complementam as informações do capítulo anterior, como também aprofundam o entendimento sobre o teor da discussão naquele momento de trâmite do projeto de lei.

As Audiências Públicas são espaços de participação social em que a administração pública se abre para ouvir e interagir com o cidadão. É um momento em que a sociedade civil organizada procura influenciar as decisões políticas. No caso do Poder Legislativo, é um momento em que é possível influenciar a formulação de uma política pública. Com a apresentação de dados estatísticos e pesquisas acadêmicas, além de relatos de experiências e histórias de vida; os atores políticos procuram nas Audiências Públicas contribuir com suas perspectivas. 
Nesse sentido, acredita-se que a análise de conteúdo das Audiências Públicas pode ser muito rica na reconstrução do cenário de formação da Lei de Cotas. O capítulo está dividido nas seguintes partes: 1) Informações Gerais sobre as Audiências Públicas analisadas; 2) Audiências Públicas da Câmara dos Deputados; 3) Audiências Públicas do Senado Federal; e 4) Considerações finais.

\subsection{AUDIÊNCIA PÚBLICA: MECANISMO DE PARTICIPAÇÃO SOCIAL E LEGITIMAÇÃO DAS DECISÕES POLÍTICAS}

As Audiências Públicas têm um significativo lastro legal, tanto é que a maioria da produção acadêmica relacionada à temática é da área do Direito, mais especificamente do Direito Administrativo. Longe de pretender conduzir esse trabalho pelo caminho dessa área de conhecimento, apenas faremos referência pontual a juristas que podem auxiliar na compreensão do que é uma audiência pública. Sabe-se que o objetivo central da realização delas é a ampliação da legitimidade democrática das decisões tomadas pela administração pública. Conforme afirma Maria Macedo Nery Ferrari (2003), audiências públicas são:

\section{(...) processos de participação popular que proporcionam o aperfeiçoamento da legitimidade das decisões da Administração Pública decorrente de exposição de tendências, preferências e opções, por parte da população, que devem conduzir as decisões e a atuação do poder público a uma maior aceitação social (op.cit., p. 343).}

Nesse sentido, tais eventos dão maior respaldo popular às decisões tomadas pelo sistema político, uma vez que a decisão considera as ponderações de distintos grupos sociais. Além de legitimar as decisões, as audiências públicas têm potencial para ampliar a eficiência e eficácia das políticas, já que, ao ouvir os interessados, os tomadores de decisão podem resolver considerando mais informações e dados sobre o assunto.

No Brasil, a prática das audiências públicas tem se popularizado em todos os âmbitos federativos, em parte pela pressão popular que tem demandado maior diálogo e em parte por imposição normativa. A Constituição Federal de 1988 trata especificamente das audiências públicas que são realizadas nas comissões do Congresso Nacional, no artigo 58, §2 ${ }^{\circ}$ inciso II, que diz:

Artigo 58. O Congresso Nacional e suas casas terão comissões permanentes e temporárias, constituídas na forma e com as atribuições previstas no respectivo regimento ou no ato de que resultar a sua criação.

$\S 2^{\circ}$ Às comissões, em razão da matéria de sua competência, cabe:

II - Realizar audiências públicas com entidades da sociedade civil. 
Em algumas áreas, há a obrigatoriedade de realização das Audiências Públicas. Apesar de as políticas públicas sociais não estarem incluídas entre as áreas com obrigatoriedade de realização de audiências públicas para tomada de decisão, sabe-se que as comissões das áreas sociais do Congresso Nacional são muito ativas na realização dessas discussões.

Em relação ao tema específico desse trabalho, as ações afirmativas, no período de tramitação do projeto de lei que deu origem à Lei de Cotas foram realizadas sete audiências públicas no Congresso Nacional. Sendo quatro na Câmara dos Deputados e três no Senado Federal. A tabela a seguir apresenta os títulos e datas de realização desses eventos:

Tabela 9 - Informações gerais sobre Audiências Públicas realizadas no Congresso Nacional

\begin{tabular}{|c|c|c|c|}
\hline \multicolumn{4}{|c|}{ Audiências Públicas } \\
\hline \multicolumn{4}{|c|}{ Câmara dos Deputados } \\
\hline Data & Denominação do evento & Convidados & Parlamentares Presentes \\
\hline $13 / 05 / 2004$ & $\begin{array}{l}\text { Audiência Pública Sistema de } \\
\text { cotas em instituições de } \\
\text { ensino superior público }\end{array}$ & $\begin{array}{l}\text { Matilde Ribeiro (SEPPIR); Nelson Maculan Filho (MEC); } \\
\text { Sônia Malheiros Miguel (SPM); Timothy Martin } \\
\text { Mulholand(UnB). }\end{array}$ & $\begin{array}{l}\text { Deputado Carlos Abicalil (PT/MT); Deputado João Matos } \\
\text { (PMDB/SC); Deputado Ivan Valente (PSOL/SP); Deputada } \\
\text { Iara Bernardi (PT/SP), Deputado Gilmar Machado (PT/SP); } \\
\text { Deputado Átila Lira (PSB/PI); Deputado Severiano Alves } \\
\text { (PDT/BA); Deputado Chico Alencar (PSOL/RJ); Deputado } \\
\text { Gastão Vieira (PMDB/MA); Deputado Luciano Leitoa } \\
\text { (PSB/MA); Deputado Colombo (PT/PR); Deputado Murilo } \\
\text { Zauith (PFL/MS). }\end{array}$ \\
\hline $15 / 06 / 2004$ & $\begin{array}{l}\text { Audiência Pública Sistema de } \\
\text { cotas em instituições de } \\
\text { ensino superior público } \\
\text { Sumário: Discussão sobre a } \\
\text { adoção de cotas raciais e } \\
\text { étnicas nas universidades } \\
\text { públicas. }\end{array}$ & $\begin{array}{l}\text { Frei David Raimundo dos Santos (Educafro); Marcelo Brito } \\
\text { (UBES); Hédio Silva Júnior (CEERT); Maria José de Jesus } \\
\text { Alves Cordeiro ( UEMS); Flávio Jorge Rodrigues da Silva } \\
\text { (CONEN). }\end{array}$ & $\begin{array}{l}\text { Deputado Carlos Abicalil (PT/MT); Deputado Jairo Carneiro } \\
\text { (PP/BA); Deputado Luiz Alberto (PT/BA); Deputado Paulo } \\
\text { Rubem Santiago (PT/PE); Deputado Chico Alencar } \\
\text { (PSOL/RJ); Deputada Maria do Rosário (PT/RS); Deputado } \\
\text { Ivan Valente (PSOL/SP); Deputado Babá (PSOL/RJ); } \\
\text { Deputado Eduardo Valverde (PT/RO); Deputado João } \\
\text { Grandão (PT/MS) }\end{array}$ \\
\hline $25 / 04 / 2006$ & $\begin{array}{l}\text { Sumário: Debate sobre o } \\
\text { Projeto de Lei no } 73 / 1999, \\
\text { relativo à reserva de vagas } \\
\text { para estudantes egressos de } \\
\text { escola pública em instituições } \\
\text { federais de ensino superior. }\end{array}$ & $\begin{array}{l}\text { Timothy Mulholland (UnB); Hédio Silva Júnior (CEERT); } \\
\text { Demétrio Magnoli (USP); Renato Pedrosa } \\
\text { (CONVEST/UNICAMP); Yvonne Maggie (UFRJ); Gustavo } \\
\text { Lemos Petta (UNE) Renato Ferreira (UERJ). }\end{array}$ & $\begin{array}{l}\text { Deputada Neyde Aparecida (PT/GO), Deputado Luiz } \\
\text { Eduardo Greenhalgh (PT/SP),Deputada Maria do Rosário } \\
\text { (PT/RS) } \\
\text { Deputada Iara Bernardi (PT/SP), Deputado Carlos Abicalil } \\
\text { (PT/MT), Deputado Alberto Goldman (PSDB/SP), Deputado } \\
\text { Eduardo Seabra (PTB/AP), Deputado Luiz Alberto (PT/BA), }\end{array}$ \\
\hline $25 / 04 / 2006$ & $\begin{array}{l}\text { Sumário: Debate sobre a } \\
\text { reserva de vagas em } \\
\text { instituições federais de ensino } \\
\text { superior. }\end{array}$ & $\begin{array}{l}\text { Fernando Haddad (MEC); Matilde Ribeiro (SEPPIR); Eunice } \\
\text { Durham (USP); Valdélio Santos Silva (UNEB); Fábio } \\
\text { Konder Comparato (USP). }\end{array}$ & $\begin{array}{l}\text { (PV/MG), Deputado João Paulo Cunha (PT/SP), Deputada } \\
\text { Maria do Carmo Lara (PT/MG), Deputado Chico Alencar } \\
\text { (PSOL/RJ), Deputada Nice Lobão (PSD/MA), Deputado } \\
\text { Professor Luizinho (PT/SP), Deputado Evandro Milhomen } \\
\text { (PCdoB/AP), Deputado Ivan Valente (PSOL/SP), Deputado } \\
\text { Severiano Alves (PDT/BA), Deputado Eduardo Valverde } \\
\text { (PT/RO), Deputado Átila Liro (PSB/PI), Deputado Daniel } \\
\text { Almeida (PCdoB/BA), Deputado Nilson Pinto (PSDB/PA) }\end{array}$ \\
\hline $18 / 11 / 2009$ & $\begin{array}{l}\text { Sumário: Debate sobre o } \\
\text { sistema de cotas para } \\
\text { afrodescendentes nas } \\
\text { universidades públicas. }\end{array}$ & $\begin{array}{l}\text { Jaciara da Silva ( MNU); Deborah Santos (CCN/UnB); } \\
\text { Mário Theodoro (IPEA); Nelson Inocêncio (UnB/CDDN- } \\
\text { DF). }\end{array}$ & $\begin{array}{l}\text { Deputado Pedro Wilson (PT/GO), Deputado Luiz Couto } \\
\text { (PT/PB), Deputado Luiz Alberto (PT/BA), Deputada Janete } \\
\text { Rocha Pietá (PT/SP), Deputada Janete Capiberibe } \\
\text { (PSB/AP), Deputado Veloso (PPS/BA) }\end{array}$ \\
\hline
\end{tabular}




\begin{tabular}{|c|c|c|c|}
\hline \multicolumn{4}{|c|}{ Senado Federal } \\
\hline $18 / 12 / 2008$ & $\begin{array}{l}1^{\text {a }} \text { Audiência Pública para } \\
\text { instruir o PLC 180/2008. }\end{array}$ & $\begin{array}{l}\text { André Lázaro (MEC); Frei David Santos (Educafro); Sérgio } \\
\text { José Custódio (MSU); Yvone Maggie(UFRJ); José Roberto } \\
\text { Militão (AFROLUX); José Carlos Miranda (MNS); Jerson } \\
\text { César Leão Alves (MNM); Deise Benedito (UnB) }\end{array}$ & $\begin{array}{l}\text { Senadora Serys Slhessarenko (PT/MT) ; Senador } \\
\text { Demóstenes Torres (DEM/GO); Senador Paulo Paim } \\
\text { (PT/RS) e Senador Cristovam Buarque (PPS/DF); Senadora } \\
\text { Marina Silva (PV/AC); Senadora Fátima Cleide (PT/RO); } \\
\text { Senadora Ideli Salvatti (PT/SC); Senador Pedro Simon } \\
\text { (PMDB/RS); Senador Eduardo Suplicy (PT/SP); Senador } \\
\text { Lobão Filho (PMDB/MA); Senador Virgínio de Carvalho } \\
\text { (PSC/SE)e o Senador Marco Maciel (PFL/PE). }\end{array}$ \\
\hline $18 / 03 / 2009$ & $\begin{array}{l}2^{\mathrm{a}} \text { Audiência Pública para } \\
\text { instruir o PLC 180/2008. }\end{array}$ & $\begin{array}{l}\text { Bolívar Lamounier (USP); Demétrio Magnoli (USP); Helderli } \\
\text { Castro de Sá Alves (ONG Nação Mestiça); Francisco Jhony } \\
\text { Rodrigues Silva (FORAFRO); Vera Fávero (MNS); Willian } \\
\text { Douglas (Educafro); Augusto Werneck (PUC-RJ); Daniel } \\
\text { Cara (Campanha pelo direito à educação); Wellington do } \\
\text { Carmo Faria (MSU); Rosani Fernandes Kaingang (Fórum de } \\
\text { Educação Indígena). }\end{array}$ & $\begin{array}{l}\text { Senador Tasso Jereissati (PSDB/CE), Senador Francisco } \\
\text { Dornelles (PP/RJ), Senadora Ideli Salvatti (PT/SC), Senador } \\
\text { Cristovam Buarque (PPS/DF), Senadora Serys Shessarenko } \\
\text { (PT/MT), Senador Wellington Salgado de Oliveira } \\
\text { (PMDB/MG), Senador Marcelo Crivella (PRB/RJ), Senador } \\
\text { Lobão Filho (PMDB/MA), Senador Eduardo Suplicy } \\
\text { (PT/SP), Senador Inácio Arruda (PCdoB/CE) e Senador } \\
\text { Demóstenes Torres (DEM/GO). }\end{array}$ \\
\hline 01/04/2009 & $\begin{array}{l}\text { 3ª Audiência Pública para } \\
\text { instruir o PLC 180/2008. }\end{array}$ & $\begin{array}{l}\text { Edson Santos de Souza (SEPPIR); Amaro Lins (UFPE); } \\
\text { José Roberto Pinto de Góes (UERJ); Ismael Cardoso } \\
\text { (UBES); Simon Schwartzman (IBGE); Renato Ferreira } \\
\text { (UERJ). }\end{array}$ & $\begin{array}{l}\text { Senadora Serys Slhessarenko (PT/MT), Senador Tasso } \\
\text { Jereissati (PSDB/CE), Senador Antônio Carlos Valadares } \\
\text { (PSB/SE), Senador Romeu Tuma (PFL/SP). }\end{array}$ \\
\hline
\end{tabular}

Fonte: Produzido pela autora

Em linhas gerais, é possível identificar os grupos que estiveram frequentemente participando das audiências públicas: os movimentos sociais, em sua maioria favorável a política de cotas; a comunidade acadêmica, composta por estudantes, professores e reitores, entre esses nota-se uma diversidade grande de opiniões; a grande mídia, que acompanhou de perto todo o processo; e, entre os servidores públicos, haviam aqueles de órgãos vinculados à temática racial e também outros órgãos; e os próprios parlamentares.

\subsection{AUDIÊNCIAS PÚBLICAS SOBRE COTAS NA CÂMARA DOS DEPUTADOS}

\subsection{1 $1^{a}$ Audiência Pública (13/05/2004) - Introduzindo o debate: um diálogo entre o Poder Executivo e o Poder Legislativo}

Como nota-se na tabela anteriormente apresentada, a primeira audiência pública sobre o tema contou com a participação de órgãos governamentais do Poder Executivo (SEPPIR/PR, SPM/PR e MEC), e com o Vice-reitor da Universidade de Brasília. Vários 
parlamentares participaram dos debates apresentando nesse momento suas dúvidas, preocupações e sugestões para a questão em discussão.

A marcante presença institucional nessa primeira audiência pública delimitou a forma como se deu a discussão, em tom conciliador e de agregação de propostas. No dia desse evento ainda não havia sido apresentada nenhuma proposta do Executivo, então tanto a Ministra Matilde Ribeiro (SEPPIR/PR) como o secretário de ensino superior do MEC Nelson Maculan Filho fizeram elogiosos comentários ao engajamento do Poder Executivo na construção de duas propostas: a medida provisória do PROUNI e a Lei de Cotas. Ambos afirmaram que tais propostas buscavam tratar de uma necessidade abrangente do ensino superior brasileiro que era sua democratização.

Em sua apresentação, a Ministra Matilde Ribeiro dá importância ao histórico de luta do movimento negro, às regulamentações internacionais sobre Direitos Humanos que recomendam adoção de ações afirmativas e faz referência a algumas experiências iniciadas no país. Além disso, parece especialmente interessante para a reconstrução desse cenário de construção da Lei uma afirmação da Ministra que indica que a proposta de Lei de Cotas estava sendo elaborada a princípio como uma medida provisória discutida por vários órgãos do Poder Executivo.

O debate sobre a política de cotas intensificou-se do ano passado para cá. Foi formado um grupo de trabalho interministerial, coordenado pela SEPPIR/PR e pelo MEC, composto por mais de 8 organismos do Governo Federal. Em quatro meses de trabalho, foi elaborada uma proposição entregue ao Presidente da República no final do ano passado, tendo sido reformulado em janeiro. E essa é a matéria que está em pauta hoje. O grupo de trabalho interministerial, após uma avaliação desse processo histórico, apresentou ao Presidente da República proposta de medida provisória contendo diversos artigos em que se externava a importância de se levar à frente a política de implementação de cotas para negros e indígenas nas universidades públicas federais (Ministra Matilde Ribeiro, Notas Taquigráficas, 13/05/2004 Audiência Pública Câmara dos Deputados, p.6).

Na participação do Secretário de Educação Superior do MEC observamos outro indício de como essa proposta estava sendo pensada e formulada no âmbito do Executivo Federal.

Nesse sentido, o Presidente Luiz Inácio Lula da Silva enviará a esta Casa projeto de lei que institui o Programa Universidade para Todos, voltado para o acesso democrático nas instituições de ensino não-público e que prevê a utilização das vagas ociosas dessas instituiçõos de ensino superior privadas por meio da concessão de bolsas a estudantes originários de famílias de baixa renda. As bolsas serão concedidas pelas próprias instituições mediante processo seletivo implementado pelo Ministério da Educação. A adesão das instituições de ensino ao programa se 
fará por intermédio de convênio com o Governo Federal, concedendo-se isenção de alguns impostos e contribuições.

Em relação às universidade federais, o Presidente Luiz Inácio Lula da Silva estará ainda muito brevemente encaminhando à apreciação dos Parlamentares projeto de lei que institui sistema especial de reserva de vagas para estudantes egressos das escolas públicas, em especial negros e indígenas, em instituições públicas federais de educação superior, que, pelo decreto de lei citado, deverão reservar, na ocasião de cada concurso ou seleção para o ingresso em curso de graduação, um número mínimo de vagas para estudantes que tenham cursado integralmente o ensino médio em escolas públicas. O fato é que a reserva de vagas para negros e índios nas instituições de educação superior nos coloca diante do desafio de admitir a exclusão e trabalhar politicamente contra ela. (Nelson Maculan Filho, 13/05/2004 - Audiência Pública Câmara dos Deputados, p.8).

A partir dessas duas referências, salvo melhor entendimento, ao que tudo indica a proposição inicial incluía PROUNI e Lei de Cotas em uma só matéria. Ao observarmos as possibilidades de ação do Poder Executivo junto ao Poder Legislativo sabe-se que a apresentação de medida provisória propicia uma tramitação mais acelerada da proposta. Desse modo, a escolha por apresentar o PROUNI como medida provisória e a Lei de Cotas como projeto de lei oferece pistas sobre as prioridades do Poder Executivo. Aparentemente, o PROUNI e sua proposta de expansão do número de estudantes no ensino superior privado teve preferência em relação à Lei de Cotas e sua proposta de inclusão no ensino superior público.

Vale destacar outros aspectos que foram reiteradas vezes apresentados e discutidos, são eles: a judicialização das cotas; a expansão do ensino superior; e a permanência dos estudantes cotistas. Alguns participantes da audiência pública afirmaram a importância de haver uma regulamentação federal sobre as cotas de modo que houvesse maior respaldo jurídico para as Universidades que estavam seguindo este caminho, bem como incentivasse as demais. Conforme demonstram os trechos abaixo:

Acreditamos que, se o Poder Legislativo sinalizar claramente para a sociedade, principalmente para as universidades públicas - como é o nosso caso -, teremos respaldo legislativo para fazer esse tipo de experiência, teremos mais tranqüilidade. O mesmo acontecerá com outras universidades (Timothy Mulholand, Notas Taquigráficas - Audiência Púbica - 13/05/2004).

Com referência às experiências que estão sendo realizadas no País, quero dizer que nós, tanto o Executivo quanto o Legislativo, ao assumirmos nossa parcela de responsabilidade de levar adiante o sistema que cria oportunidades para quem não as teve, reforçaremos muitas experiências já em curso espalhadas pelo Brasil e também daremos condição para que instituições de ensino que se têm posicionado de forma contrária à proposta ou que estejam em dúvida possam se ver respaldadas por uma lei que garanta esse encaminhamento (Matilde Ribeiro, Notas Taquigráficas Audiência Pública Câmara dos Deputados - 13/05/2004). 


\begin{abstract}
Nossa reflexão sobre o tema da inclusão racial nos leva à constatação de que muitas universidades que já implantaram o sistema de reserva especial de vagas para negros e índios sofrem diante da perspectiva de ações judiciais, em razão da ausência de lei federal que regule o tema. Já defendemos instituições de ensino superior que estão assumindo essa posição de conceder cotas para negros e índios em inúmeras ações judiciais. Então é muito importante que exista uma lei que regularize esse tipo de trabalho, senão nossos colegas reitores ficarão expostos a batalhas judiciais, com dificuldade de tocarem seus projetos de cotas nas universidades. (Nelson Maculan Filho, Notas Taquigráficas - Audiência Pública Câmara dos Deputados 13/05/2004).
\end{abstract}

As temáticas da expansão do ensino superior e da permanência desses estudantes cotistas nas universidades foram trazidas principalmente por parlamentares. Estes também apresentaram vários argumentos que apontavam para o enfraquecimento do ensino superior público, para a escassez de recursos, para o não investimento na contratação de professores e na construção de novos campi. A preocupação também se demonstra com relação ao transporte, alimentação, saúde e condições financeiras para realização dos cursos, com a argumentação de que estudantes pobres teriam dificuldades de se manter ainda que em universidades públicas.

Tais provocações feitas pelos parlamentares apresentaram-se no sentido de questões e novas propostas para serem incluídas nas matérias em produção. Um último ponto que convém destacar desta audiência pública refere-se ao tratamento das ações afirmativas como medidas que desestabilizam relações de poder consolidadas no país. Como vem sendo discutido nesse trabalho, o racismo institucional parece demonstrar-se nessa tramitação legislativa, colocando a questão racial à margem da proposta. E parece especialmente interessante que a proposta de ações afirmativas apareça justamente como uma alternativa de radicalização democrática, conforme dito pela diretora de articulação institucional da SPM/PR, Sônia Malheiros Miguel:

\begin{abstract}
A discussão que as cotas levanta quanto à relação de poder estruturada em nossa sociedade é outro ponto fundamental, porque, a partir dela, podemos debater outras relações desiguais de poder existentes. Ela é um ponto de entrada na discussão desse tema que entendemos fundamental. A política de ação afirmativa reconhece a discriminação e age não só no sentido de impedir que essa discriminação se perpetue, mas também no sentido de recuperar mais rapidamente a situação de equilíbrio. Ela intervém na sociedade para além do discurso e atua no sentido de fazer com que as desigualdades percebidas, de ordem racial ou sexual, sejam radicalmente resolvidas por meio de políticas compensatórias, com o objetivo de reequilibrar mais rapidamente esse jogo de forças (Sônia Malheiros, Notas Taquigráficas da Câmara dos Deputados - 13/05/2004, p.10).
\end{abstract}

Como nota-se, essa primeira audiência não contou com a participação da sociedade civil, nem de movimentos sociais. Deu-se um diálogo entre agentes do Poder Executivo e do 
Poder Legislativo, bem como a apresentação de defesa da experiência em curso da Universidade de Brasília. Nenhum dos participantes, mesmo entre os parlamentares, manifestou-se expressamente contra as cotas, porém, nota-se que desde a primeira audiência pública a tensão sobre a temática cotas sociais e cotas raciais estava colocada. Tanto a Ministra Matilde Ribeiro, que afirma algumas vezes que se trata de um problema difícil e que a solução de junção das cotas foi a alternativa negociável com o MEC, como o deputado Gilmar Machado (PT/SP) que questiona com veemência a resistência às cotas raciais, e argumenta que para outros tipos de cotas já existentes não há a mesma dificuldade dão a entender que o conflito sobre esse assunto já estava colocado neste momento.

\subsection{2 $2^{\text {a }}$ Audiência Pública (15/06/2004) - Abrindo espaço para a participação da sociedade civil}

Em maio de 2004, o Poder Executivo apresentou dois projetos de lei: o da Lei de Cotas e o do PROUNI. Esta Audiência Pública ocorreu, portanto, meses após essa iniciativa. E isso fez com que várias manifestações ocorressem no sentido de comentar esses projetos. A leitura das notas taquigráficas demonstra que houve grande participação da sociedade civil neste evento. Em vários momentos, os documentos informam que o auditório estava cheio, e que haviam várias pessoas impossibilitadas de entrar no recinto dada a lotação. Foi necessária transmissão da Audiência Pública em outra sala da Câmara dos Deputados para se comportar a demanda por participação. Para fins de registro, logo abaixo está a tabela com as organizações sociais apresentadas ao longo desta Audiência Pública.

\begin{tabular}{|l|}
\hline \multicolumn{1}{|c|}{ Movimentos Sociais Citados } \\
\hline EDUCAFRO \\
\hline União Brasileira de Estudantes Secundaristas - UBES \\
\hline Organizações Indígenas da Amazônia Brasileira - COIAB \\
\hline Sindicato dos Professores do Ensino Oficial de São Paulo \\
\hline Confederação Nacional dos Trabalhadores em Educação \\
\hline Movimento Ruptura Socialista \\
\hline União dos Estudantes Secundaristas de Planaltina \\
\hline UNEGRO \\
\hline União Metropolitana dos Estudantes Secundaristas de Brasília \\
\hline PréLoyola \\
\hline Coletivo de Estudantes Negros da UnB - EnegreSer \\
\hline
\end{tabular}




\begin{tabular}{|l|}
\hline Federação de Sindicatos dos Trabalhadores das Universidades Brasileiras - FASUBRA \\
\hline Central Única dos Trabalhadores - CUT \\
\hline União Colegial de Minas Gerais \\
\hline União da Juventude Socialista - UJS \\
\hline Rede Oficial de Ensino de São Paulo \\
\hline Confederação Nacional dos Trabalhadores da Educação - CNTE \\
\hline
\end{tabular}

Chama a atenção e mais uma vez aponta para a importância do debate a variedade dos atores envolvidos, desde políticos locais (prefeitos, vereadores); passando pela comunidade acadêmica (reitores, professores e estudantes); organizações educacionais; movimentos sociais negros e indígenas, entre outros.

Sendo assim, diferentemente da audiência pública anterior, esta contou com a presença significativa da sociedade civil na discussão do assunto. Consideramos relevante destacar alguns pontos centrais do debate, selecionados a partir dos objetivos deste trabalho, são eles: a importância da mídia; a contraposição aos argumentos contra cotas; a valorização das experiências existentes; e a constitucionalidade das cotas.

O primeiro aspecto que pode ser destacado nessa audiência pública é a centralidade que a mídia ganhou nas discussões realizadas. Em muitas falas, tanto dos palestrantes como dos parlamentares, citou-se a forte influência da mídia sobre a opinião pública e sua postura majoritariamente contrária às ações afirmativas. Logo no início do evento, o Deputado Luiz Alberto (PT/BA) afirma:

\footnotetext{
(...) hoje, no jornal O Globo, foi divulgado o artigo de um jornalista, Ali Kamel, que faz um discurso evidentemente na contramão desse processo ora em debate. Vai mais além. Não só se define como contrário à proposta de inclusão de uma política de ações afirmativas e cotas em particular, mas vai além disso. Ele nega de forma enfática a existência de racismo no nosso País. Portanto, nós (...) sabíamos que esse debate seria talvez a porta de entrada para que a sociedade brasileira se posicionasse de forma objetiva sobre a existência ou não de racismo em nosso País. (Deputado Luiz Alberto, 15/06/2004, Audiência Pública Câmara dos Deputados, p.4 e 5).
}

Outros participantes da audiência também falaram sobre o papel que a mídia vinha desenvolvendo nesse processo e seus resultados. De acordo com o Frei David: "a postura contrária da imprensa acabou rendendo positivamente para a comunidade negra, pois obrigou que o assunto ficasse na ordem do dia por longo período - e está até hoje.” (p. 6, Frei David dos Santos, 15/06/2004, Audiência Pública Câmara dos Deputados). Este impacto também é abordado pelo Deputado Ivan Valente (PSOL/SP): 
(...) de acordo com pesquisa atual - tenho a em mão -, $61 \%$ da população apoiam o sistema de cotas; $29 \%$ são contra; e $9 \%$ ainda não têm posição firmada. Não nos iludamos com isso, porque a batalha ainda não começou. Há os formadores de opinião, a mídia e a elite brasileira, que controla a mídia, os meios de comunicação que exerce grande influência. Mas também é verdade que há a luta popular, democrática e a pressão de baixo para cima, a que estamos assistindo aqui (Deputado Ivan Valente, 15/06/2004, Audiência Pública Câmara dos Deputados, p.26).

Desse modo, nesse momento, parece já estarem colocadas algumas forças favoráveis e contrárias às cotas no Brasil, sendo possível observar que alguns dos maiores veículos de imprensa posicionavam-se contra essas medidas. Nessa audiência pública, porém, todos os convidados palestrantes e todos os parlamentares que fizeram uso da palavra posicionaram-se favoráveis às ações afirmativas e às cotas.

Interessante observar que, mesmo sendo todos os participantes favoráveis às cotas, a maioria deles direcionou a maior parte de sua participação a se contrapor aos argumentos contra cotas que rondavam a discussão à época. Hédio Silva Jr. (organização), por exemplo, focou a sua participação em apresentar contra-argumentos a três questões: 1) a inconstitucionalidade ou ilegalidade das cotas; 2) a ideia de que as políticas de ações afirmativas criariam um sistema de classificação racial no país, e consequentemente, uma 'divisão racial'; 3) o argumento de que as cotas tornariam vulnerável a meritocracia dos vestibulares, bem como promoveriam uma injustiça contra os brancos pobres.

Sobre o primeiro ponto, Hédio Silva Jr. fez uma retomada histórica sobre as bases do direito brasileiro e do direito dos Estados Unidos, concluindo que as ações afirmativas são uma prática histórica do Estado brasileiro, ao considerar que, desde a década de 1930, promove a reserva de vagas para favorecer outros grupos não-negros, além do fato de que diversos acordos internacionais assinados pelo Brasil preveem essas medidas. Sobre a segunda ideia, o professor Hédio Silva Jr., retoma historicamente os momentos em que o Estado realiza classificação racial e, conforme sua argumentação, no Direito Penal, para identificação de réus, utilizando geralmente, a categoria cor/raça. E sobre o terceiro argumento, o palestrante informou não haver evidências empíricas que comprovassem a redução da qualidade do ensino devido à implementação de cotas, uma vez que se busca flexibilizar o acesso e não os mecanismos avaliativos do ensino superior público do país.

Outro participante da audiência pública que apresentou argumentos que se contrapõem aos opositores das cotas foi Marcelo Brito da Silva, o então presidente da União Brasileira de 
Estudantes Secundaristas (UBES). Entre os questionamentos, a questão da meritocracia foi analisada por ele, que, após exemplificar o dia-a-dia de estudantes de escolas privadas e de estudantes de escolas públicas, questiona quem teria mais mérito em ingressar no ensino superior público. A preocupação com a assistência estudantil e as condições de permanência dos estudantes ingressantes também foi tópico importante de sua participação.

Cabe ressaltar também que, em sua apresentação, o representante da UBES apresenta o histórico de atuação da organização em relação às cotas, e seu enfoque na defesa da reserva de vagas para estudantes de escolas públicas. Apesar de não apresentar explicitamente a tensão entre a pauta de cotas sociais $x$ cotas raciais, a fala de Marcelo Brito aponta para a predominância no interesse em defender as cotas sociais ou para escolas públicas.

\footnotetext{
Em 1995, a UBES, no seu congresso nacional, realizado em Goiânia, aprovou a proposta que versava sobre a defesa de reserva de vagas para estudantes de escolas públicas nas universidades públicas. Desse ano para cá, a UBES trava um debate, no movimento estudantil, com a sociedade brasileira, dizendo que as universidades públicas brasileiras, sejam elas estaduais ou federais, deveriam reservar $50 \%$ das suas vagas a estudantes egressos de escolas públicas. Essa luta tem feito com que a UBES enfrente diversos desafios, diversos obstáculos. (Marcelo Brito, Audiência Pública Câmara dos Deputados 15/06/2004, p.8).
}

O terceiro ponto que resolvemos destacar na análise desse evento foi a valorização de experiências anteriores. Nesta audiência pública aconteceu a exposição detalhada da experiência de formulação e início da implementação das cotas na Universidade Estadual do Mato Grosso do Sul pela então pró-reitora Maria José de Jesus Alves Cordeiro. Também foram citadas e aplaudidas as iniciativas das Universidades Estaduais do Rio De Janeiro, da Universidade do Estado da Bahia e da Universidade de Brasília. Intervenções de parlamentares demonstravam interesse nas experiências e práticas já existentes, de modo a contribuir para formulação da lei.

Por fim, o quarto e último ponto diz respeito à questão da constitucionalidade e legalidade das cotas para ingresso no ensino superior. Como se sabe, naquele momento ainda não havia nenhuma decisão do STF sobre o tema, sendo que as decisões judiciais sobre o assunto apresentavam entendimentos muito diversos. Assim como na primeira audiência pública, nota-se que nesta também havia preocupação com relação ao acionamento judicial e as respostas que o sistema judiciário daria à questão. De acordo com o que expôs Frei David dos Santos: 
Em plena celebração do mês de Zumbi, em 2003, a sociedade brasileira foi agraciada com esta notícia em 24 de novembro: Tribunal de Justiça do Rio de Janeiro nega suspensão da lei de cotas. O (...) Tribunal de Justiça negou o pedido de liminar para suspensão da lei de cotas referente à reserva de vagas nas universidades (...).

Qual é o significado dessa vitória? Na primeira abordagem desse assunto, na Justiça do Rio, as reações dos Juízes foram desastrosas. Agiram sem conhecer o assunto. Houve um grande trabalho da comunidade negra. A Revista da Magistratura foi acionada e fez ricas reportagens, dando aos Juízes os subsídios para sua reflexão. (...) Dezenas de seminários foram realizados no Brasil, principalmente no Rio de Janeiro, inclusive na Escola de Magistratura daquele Estado. Cada Juiz e cada Desembargador receberam em sua mesa um dossiê fruto desse seminário. (...)

Nove meses depois, os Juízes são novamente provocados a se posicionar. Surpresa: a grande maioria amadureceu no que diz respeito ao conhecimento das ações afirmativas. A estratégia deu certo! Cotas, instrumento temporário para provocar reflexão (Frei David dos Santos, Audiência Pública Câmara dos Deputados15/06/2004, p. 6).

É possível afirmar que, nesse momento histórico, a insegurança jurídica sobre o assunto era enorme. A criação de uma lei federal sobre o tema, bem como o questionamento sobre a constitucionalidade das cotas da UnB no STF que levou a uma decisão unânime, parecem responder às demandas e aflições desse período.

Em resumo, a audiência pública de 15/06/2004 foi um grande evento na Câmara dos Deputados, que contou com lotação máxima da sala de realização, não sendo possível comportar todos os interessados no debate. Para além disso, nota-se que a audiência contou com pessoas majoritariamente favoráveis às cotas e às propostas em trâmite no Congresso, contudo, alguns parlamentares trataram de apontar para a resistência e dificuldade que a matéria teria em tramitar. É possível observar também que, nesse momento, as forças políticas favoráveis e contrárias começaram a ser organizar e se posicionar; sendo a mídia uma das forças contrárias e os movimentos sociais negros e indígenas uma das forças favoráveis.

\subsection{3 $3^{\text {a }}$ Audiência Pública (25/04/2006) - Primeiros embates e divergências públicas no Congresso Nacional}

A terceira Audiência Pública da Câmara dos Deputados aconteceu no momento exatamente anterior à ida do projeto de lei para o plenário daquela Casa, então, nessa data, o projeto já havia passado pelas três comissões para as quais foi despachado, como observamos 
no capítulo anterior. A audiência pública teve duração de um dia inteiro, sendo que uma primeira sessão aconteceu no período da manhã e outra no período da tarde. Os parlamentares presidentes das Comissões de Direitos Humanos e Minorias e de Educação e Cultura conduziram as discussões.

Além dessas duas autoridades, todas as mesas do dia foram compostas por professores e pesquisadores, e o único movimento social a integrar a mesa de discussões foi a União Nacional do Estudantes (UNE). O primeiro ponto de destaque nessa audiência pública foi a diversidade de opiniões entre os integrantes das mesas de discussão. Se até o momento as audiências públicas haviam abordado as ações afirmativas contando com a participação de pessoas favoráveis a proposta, no evento deste dia o cenário mostra-se mais diversificado. Pela primeira vez nas audiências públicas da Câmara dos Deputados as opiniões divergentes são abertamente colocadas.

A mesa de abertura foi composta pelo Ministro da Educação, Fernando Haddad, e pela Ministra da SEPPIR/PR, Matilde Ribeiro. Os dois procuraram defender a proposta de autoria do Executivo em trâmite no Congresso Nacional. O ministro da Educação argumentou que a proposta tinha respaldo popular por ser o cumprimento de uma promessa de campanha do presidente Lula, um projeto político aprovado nas urnas. Também fazendo uma retomada histórica da tramitação das matérias sobre esse tema no Congresso Nacional, afirmou que o conteúdo não era novidade naquela Casa, bem como não podia ser associado de modo simplista a partidos específicos, já que quase todos os partidos haviam apresentado alguma proposição sobre ações afirmativas.

De acordo com o Fernando Haddad:

\begin{abstract}
Portanto, o que eu quero sublinhar em primeiro lugar é que o recorte, a clivagem não passa pelos partidos. Mais propriamente, ela perpassa todos os partidos. Isso nem sempre é traduzido para a opinião pública de maneira adequada. Muitas vezes, isso é apresentado como se fosse a bandeira de determinado tipo de pensamento, como se estivessem os progressistas de um lado e os conservadores de outro, ou outras clivagens que possam ser artificialmente estabelecidas. Não é assim, não se verifica dessa maneira. Seria um grande erro insistir em estabelecer clivagens artificiais, para o bem do próprio projeto. (Fernando Haddad, Audiência Pública Câmara dos Deputados 25/04/2006, p.2).
\end{abstract}

Além disso, o ministro tentou defender a ideia de que a discussão do projeto não comportava o antagonismo entre racistas e não-racistas, que a discussão era mais abrangente do que isso, e que tanto entre os favoráveis como entre os contrários às cotas haviam pessoas competentes e sérias. Assim foram as palavras do Ministro: 


\begin{abstract}
Não se trata, como se verifica na imprensa muitas vezes, de debate de racistas contra não-racistas. Muitas vezes, vemos na imprensa acusações aos que são contra o projeto, como se racistas eles fossem. Há muitas pessoas sérias, e posso assegurar a todos que elas nada têm de racistas, muito pelo contrário, e são contra o projeto , como vejo também de parte da imprensa a acusação de racistas aos defensores do projeto. E aí, com mais ênfase ainda, garanto que essa não é a maneira adequada de tratar assunto tão importante como esse. Não se trata de racismo versus nãoracismo. O que se discute hoje é verificar, constatar que existem camadas da população brasileira historicamente prejudicadas. E perceber, a julgar pelas experiências em curso eu insisto em que esse não é um desejo idealizado de alguns no que se refere a políticas de afirmação de camadas sociais historicamente prejudicadas, que incluem os alunos da escola pública, sobretudo e em especial, nesse núcleo de afro-descendentes e de indígenas, que há uma forma de seleção que acaba recalcando ou reproduzindo uma lógica de exclusão de tais camadas ao acesso à educação superior gratuita e de qualidade (Fernando Hadad, Audiência Pública Câmara dos Deputados 25/04/2006, p.3).
\end{abstract}

O ministro destacou a centralidade da educação superior no desenvolvimento nacional e na formação dos quadros do país. Argumentou que naquele momento já existiam dezenas de universidades no país que estavam implementando políticas de ações afirmativas, com resultados mensurados, demonstrando que não eram observáveis prejuízos à qualidade ou a meritocracia do sistema de ensino superior brasileiro. Citou exemplos de universidades públicas com sistemas de cotas em vigência, e também fez referência ao PROUNI, iniciativa que poderia servir como uma referência concreta.

Fernando Haddad afirmou que ele, quando secretário executivo do MEC, era contra os sistemas de cotas. Sendo que mudou de opinião ao observar os sistemas existentes no país, acompanhar a mensuração dos resultados e compreender o potencial transformador desse tipo de política. Concluiu sua participação reforçando a ideia de que as políticas de cotas já estavam sendo implementadas, resultados já estavam sendo mensurados e que a proposta do Executivo em trâmite na Casa era resultado de um debate amadurecido na sociedade, que favoreceria a promoção de um acesso ao ensino superior mais republicano.

A Ministra Matilde Ribeiro iniciou sua participação explicando o papel da SEPPIR/PR na execução das políticas públicas. Apresentou informações históricas como base para as discussões que estavam acontecendo naquele momento, e afirmou:

A população negra ajudou a construir nossas riquezas desde os primórdios da nossa história, mas não usufrui dos seus benefícios na mesma proporção dos demais grupos raciais do País. Assim como também os povos indígenas, que, diferentemente da população negra, sofreram quase um genocídio ao longo da nossa história. Portanto, o reconhecimento dos efeitos dessa situação peculiar no nosso País, do racismo existente na nossa sociedade e da necessidade de o Estado brasileiro, representado pelos Governos, tomar para si parte da responsabilidade da superação dessa condição, foi o que permitiu a criação da Secretaria e de diversos programas neste Governo, em vários Ministérios. (Matilde Ribeiro, Audiência Pública Câmara dos Deputados 25/04/2006, p.6). 
A ministra fundamentou a atuação da SEPPIR/PR em várias resoluções internacionais ratificadas pelo país, e no plano de governo de Lula, que construiu o programa "Brasil sem Racismo". Sobre o projeto em pauta, a ministra reafirmou que a SEPPIR/PR fez parte do processo de construção da matéria, discutindo juntamente com o MEC qual seria o formato mais adequado para a implementação das ações afirmativas no ensino superior. Tratou as experiências da UNEB (Universidade do Estado da Bahia), UERJ (Universidade do Estado do Rio de Janeiro) e UnB como emblemáticas e sinalizadoras do momento histórico que vivia o Brasil.

Após a participação da ministra, a primeira mesa de discussão foi formada com os professores Eunice Durham (USP), Valdélio Santos Silva (UNEB) e Fábio Konder Comparato (USP). A professora Eunice Durham (USP) posicionou-se contrária às cotas, construindo sua argumentação mais focada na questão da desigualdade social, nas dificuldades que pobres encontram para ingressar no ensino superior e apresentando como proposta o investimento do Estado em pré-vestibulares que formassem estudantes capazes de concorrer no vestibular.

Valdélio Santos (UNEB) posicionou-se favorável às cotas e iniciou sua participação afirmando existirem duas premissas que embasam essa discussão: 1) reconhecer que o racismo é operador das desigualdades sociais no Brasil; 2) as políticas de cotas se justificam como forma de superar os obstáculos objetivos e subjetivos criados pelo racismo, que impedem que a população negra concorra em igualdade de condições com outros grupos raciais existentes. Após isso, organizou sua apresentação em torno das ideias contrárias às cotas que ele discordava, e também apresentou algumas contribuições que os sistemas de cotas poderiam trazer ao país.

O sistema de cotas contribui para a reorganização do sistema de ensino, a fim de que sejamos incluídos como cultura e como povo. A nossa presença na universidade contribuirá fundamentalmente para que formemos os nossos quadros políticos e compartilhemos o poder político, do qual estamos afastados, inclusive no Congresso Nacional. (Valdélio Santos, Audiência Pública Câmara dos Deputados, 25/04/2006, p.14).

A última exposição foi do professor Fábio Comparato (USP), que apresentou as desigualdades sociais como tendo duas formas: a legal e a socioeconômica. Argumentou que ao se tratar de desigualdade social não é possível abordar apenas o princípio da igualdade perante a lei. Afirma que o país vive um momento chave de sua história em que descobre que 
o combate à discriminação racial não elimina a exclusão social, sendo assim, ainda que existam leis que tornem crime a discriminação racial, isso não tem reduzido a proporção de negros miseráveis. Por isso, acredita que o projeto de lei em trâmite busca levantar a dignidade do povo negro e indígena, em suas palavras, é uma proposta equilibrada e prudente.

Logo em seguida, vários parlamentares manifestaram-se com perguntas e questionamentos ao que foi apresentado pelos expositores. A leitura das notas taquigráficas permite notar que ainda que nenhum deputado se manifestasse explicitamente contrário às cotas, há maior divergência de opiniões entre eles nessa audiência pública. Ou seja, alguns deputados que inclusive já haviam participado de outras audiências públicas continuaram a manifestar seu posicionamento favorável às cotas, ao projeto de lei e a fazer menção, também, ao Estatuto da Igualdade Racial (em trâmite nesse período). Outros, que posteriormente seriam opositores declarados da proposta, apresentaram muitas dúvidas e inquietações com o projeto de lei em trâmite.

A análise das notas taquigráficas também permite constatar que essa audiência pública contava com um significativo público, que intervinha e participava bastante em cada manifestação da mesa. Em alguns momentos, as falas são interrompidas para pedir ao público que as opiniões contrárias às cotas sejam respeitadas. Em outros momentos, a mesa pede aos presentes que mantenham a ordem e não se manifestem durante as apresentações. Tudo indica que o plenário dessa audiência pública também estava cheio, e que manifestações diversas aconteceram no decorrer do evento.

No caso dessa audiência pública especificamente, localizei um relatório produzido por Fabiano Dias Monteiro ${ }^{50}$, que relata com detalhes o que ocorreu. Cabe apenas pontuar que esse relatório informa que o auditório dessa audiência pública estava lotado, que movimentos sociais como a EDUCAFRO ${ }^{51}$ e o Movimento dos Sem Universidade ${ }^{52}$ (MSU) levaram cartazes e falavam palavras de ordem durante toda a sessão. O que confirma as informações observadas nas notas taquigráficas do período da manhã dessa audiência pública.

50 O referido relatório foi localizado por essa autora no seguinte endereço eletrônico: <http://www.observa.ifcs.ufrj.br/relatorios/Rel_Aud_Pub_25042006_fdm.pdf> Acesso em 20 de jan. 2017. O senhor Fabiano Dias Monteiro atualmente é professor da Universidade Federal Fluminense, é Doutor em antropologia cultural pela UFRJ.

${ }^{51}$ EDUCAFRO é uma organização social de cursinhos pré-vestibulares comunitários, há unidades em vários Estados do país. Também são muito atuantes em todas as pautas relacionadas à questão racial. Mais informações estão acessíveis pelo site:< http://www.educafro.org.br/site/\#>.

${ }^{52}$ MSU é uma organização de cursinhos pré-vestibular popular e periférico, sediada em São Paulo. Há uma página do facebook em que são divulgadas informações sobre a organização, disponível em: <https://www.facebook.com/movimentodossemuniversidade>. 
No período da tarde, a segunda mesa de exposição contou com a presença de outros professores e pesquisadores sobre o assunto. Foram apresentadas as experiências de duas universidades que já possuíam modelos de ações afirmativas em fase de implementação e monitoramento: UnB e UNICAMP (Universidade Estadual de Campinas). Ambas possuem programas de ações afirmativas, porém seus modelos são bastante diferentes. A UnB, a época, previu um percentual fixo de reserva de vagas para estudantes negros, e uma quantidade específica vagas para estudantes indígenas na seleção; a UNICAMP, por sua vez, previa a isenção da taxa de matrícula e o acréscimo de uma porcentagem de pontos a nota do vestibular de alunos da rede pública de ensino.

O reitor da UnB, Timothy Mulholland, deu enfoque em sua participação à necessidade de expansão do ensino superior com qualidade. Defendeu e apresentou o sistema de cotas desenvolvido pela UnB pontuando os principais aspectos do debate:

\begin{abstract}
A UnB debateu o assunto abertamente por 4 anos e a posição da nossa universidade se sustenta num tripé. O primeiro é o reconhecimento da existência da discriminação racial estrutural no País. Acreditamos que ela exista, embora ainda há alguns que não acreditem. O segundo é a relevância de ações afirmativas nos casos de distorções em que as regras universalistas não estão alcançando seu objetivo de dar oportunidade, no caso da educação. E o terceiro é o papel da universidade pública, instituição que deve servir a todos os brasileiros e ser instrumento de promoção de igualdade (Timothy Mulholland, Audiência Pública Câmara dos Deputados 25/04/2006, p. 21).
\end{abstract}

Igualmente, o representante da UNICAMP apresentou e defendeu o modelo de ações afirmativas desenvolvido por sua instituição. Sobre o projeto de lei em trâmite, demonstrou preocupação quanto à padronização nacional de um modelo específico de ações afirmativas, a fixação de uma norma inflexível que, segundo ele, poderia limitar a criatividade das universidades para criarem seus próprios sistemas de inclusão social.

\begin{abstract}
Não sou contra as quotas, mas que uma experiência como a da UNICAMP (...) Há que se inscrever na lei. (...) Durante 20 anos, o Brasil precisa investir mais do dobro que vem investindo na educação. Assim, daqui a 20 anos, poderemos decidir e dizer que alguns ajustes são necessários. Não sou contra a política de quotas, mas escrever isso na lei e não dar nenhuma alternativa para as universidades, que podem adotar outro sistema, e talvez esquecer a catástrofe que é o setor educacional brasileiro, na minha opinião, será um grande equívoco para o Brasil (Renato Pedrosa, Audiência Pública Câmara dos Deputados 25/04/2006, p.12).
\end{abstract}

Os outros dois participantes, Hédio Silva Jr. e Demétrio Magnoli, protagonizaram um forte embate de ideias e posicionamentos. As opiniões divergentes levaram a audiência pública a momentos de bastante tensão, com trocas de insultos.

Hédio Silva Jr., advogado, manifestou-se primeiro e tratou de abordar alguns argumentos que comumente estavam sendo usados contra as cotas e colocá-los em questão. 
Elogiou o Congresso Nacional pela realização de audiências públicas para se debater o assunto e afirmou que muitas pessoas contrárias às cotas o são por não conhecerem as bases da discussão e não estarem presentes em eventos de debates como esse. Referiu-se à várias legislações anteriores em que foram formulados sistemas de cotas; afirmou que o desempenho no vestibular e o desempenho no decorrer do curso não são necessariamente correspondentes; e questionou a crença de que seriam as políticas de ações afirmativas a dividir o Brasil em raças.

O geógrafo Demétrio Magnoli inicia sua participação afirmando que, apesar de ter uma opinião sobre as cotas para estudantes de escolas públicas, iria focar a sua intervenção no que lhe parece essencial às cotas raciais nas Universidades Federais. Segue afirmando que o projeto de lei em discussão estava seguindo um percurso clandestino, sem debate no plenário da Câmara dos Deputados; dizendo que o projeto tinha beneficiários focalizados e perdedores difusos, sendo a nação a grande vítima.

Argumentou que qualquer política antirracista precisa se basear nos princípios iluministas de igualdade política e jurídica dos cidadãos. Demétrio Magnoli afirma que, à época, estava ocorrendo a restauração do racismo financiada por organizações nãogovernamentais, como a Fundação Ford, por exemplo. E o projeto de lei em questão seria apenas um elemento desse processo.

\footnotetext{
O PL é um elemento nesse processo. No Brasil, ele é um elemento de uma política muito mais ampla. Por isso, interessa-me colocá-lo no contexto. O PL é um elemento crucial, como formulador ideológico, de uma política conduzida pela Secretaria Especial de Políticas de Promoção da Igualdade Racial, em conexão com os Ministérios da Saúde e da Educação, que têm papéis fundamentais na produção de uma narrativa.

O ponto de chegada não é o PL das cotas raciais; o ponto de chegada é o

Estatuto da Igualdade Racial, aprovado no Senado Federal em surdina e que chegou à Câmara para ser discutido. O Estatuto da Igualdade Racial significa uma nova Constituição no Brasil; significa a abolição da idéia da Nação como um contrato entre indivíduos iguais na lei e nos direitos; significa também a criação de uma confederação de raças (Demétrio Magnoli, Audiência Pública Câmara dos Deputados 25/04/2006, p.7).
}

O professor Magnoli constrói sua argumentação em torno da discussão de que o Estado brasileiro estaria inventando identidades raciais e que essas leis possuíam características autoritárias, que construiriam um terreno para o conflito racial. E, por esses motivos, se posiciona contrariamente às cotas raciais. 
Após a exposição dos convidados da mesa, a palavra foi concedida aos deputados inscritos. Nas participações dos parlamentares criticou-se muito a afirmação do professor Magnoli de que o projeto de lei tramitou de modo clandestino. Um dos relatores da matéria, deputado Carlos Abicalil (PT/MT), afirmou:

(...) aqui não há nada de clandestino: há transparência e objetividade. Para nossa felicidade, esta é mais uma oportunidade no debate. Quem sabe um dia os Conselhos Universitários, para exercer dignamente sua autonomia, que eu defendo, farão, sim, para cada uma das suas decisões, audiências públicas inumeráveis. Convocarão para lá os hip hop da vizinhança, que não podem entrar, são barrados porque não têm suas carteirinhas de estudante de Ensino Superior ou universitário. Quem sabe, em um breve espaço de tempo, antes dos 10 anos, eu, ainda vivo, possa assistir as pesquisas científicas que darão solução à anemia falciforme, porque ainda está longe das políticas pública de largo alcance social (Calos Abicalil, Audiência Pública Câmara dos Deputados 25/04/2006, p.13).

O deputado Luiz Alberto (PT/BA) foi um pouco mais enfático ao opor-se ao professor Magnoli, afirmando que queria crer que a afirmação de tramitação clandestina poderia ter sido feita dada ignorância sobre a tramitação legislativa da casa. O deputado afirmou ler com frequência os artigos publicados pelo professor no jornal "Folha de São Paulo", e que a fala da audiência pública foi mais contundente do que as que aparecem em seus escritos. Também fez uma observação sobre as possíveis consequências da tramitação desse projeto de lei, a notar-se:

\begin{abstract}
Quando o Deputado Alberto Goldman, juntamente com alguns Deputados, fizeram recurso à Mesa da Câmara para que o projeto de lei fosse debatido em plenário, insurgisse contra essa ação. No entanto, agora quero fazer justiça e dizer que este debate foi importante. Foi importante porque finalmente, pela primeira vez estou aqui desde 1997 , vejo na Câmara dos Deputados, no Congresso Nacional o debate sobre as relações raciais no Brasil de forma profunda e responsável, porque o padrão era o do silêncio, exatamente para impedir que pudéssemos aprofundar o debate sobre a herança, sobre o legado da escravidão e do racismo que exclui mais de 90 milhões de pessoas neste País (Luiz Alberto, Audiência Pública Câmara dos Deputados 25/04/2006, p.15).
\end{abstract}

Já nas considerações finais, ao responder os parlamentares, Hédio Silva Jr. fez questão de responder às questões apresentadas pelo professor Magnoli. Vigorosamente, categorizou Demétrio Magnoli como o “inimigo público número 1" do movimento negro brasileiro. Questionou e se opôs fortemente as afirmações de que a proposta no Congresso Nacional fosse responsabilidade de um partido específico, ou de algumas pessoas, e afirmou que as propostas de ações afirmativas em discussão pertenciam ao Movimento Negro Brasileiro, que foi o protagonista e principal ator social na discussão do assunto. Bem como afirmou não admitir que a luta histórica do movimento negro fosse apresentada como lacaia de 
organizações internacionais. Após essa manifestação, o professor Magnoli afirmou não querer responder diretamente a Hédio Silva Jr., mas sim focar sua resposta nas questões colocadas por parlamentares.

A terceira mesa de debates do dia contou com a presença da UNE e de mais dois pesquisadores e professores universitários. A intervenção da UNE foi no sentido de seguir a luta pela ampliação do ensino superior, entendendo as cotas como uma medida insuficiente, mas importante nesse processo. O presidente da UNE deu ênfase ao potencial do projeto na valorização da escola pública, e no possível crescimento dos concluintes do ensino médio. Sobre as cotas raciais, a manifestação foi breve e favorável, argumentando que essas cotas podem tornar um país efetivamente mais igualitário.

Então, é necessário dar uma perspectiva maior para a juventude, e o projeto traz isso. Ele não vai resolver os problemas, não vai incluir todo mundo enquanto a universidade pública não for ampliada muitos vão ficar de fora, mas vai criar essa perspectiva maior para a juventude, como vem criando em locais onde as políticas afirmativas e a reserva de vagas já foram implementadas (Gustavo Lemos Petta, Audiência Pública Câmara dos Deputados 24/05/2006, p.27).

Também abordando a temática da igualdade e dos sistemas de cotas, o professor Renato Ferreira (UERJ) afirmou haver um equívoco entre os opositores das cotas ao recorrerem ao princípio da igualdade. Pois, a igualdade tratada por esses tem um viés exclusivamente formal, enquanto o professor acredita que a democracia exige uma igualdade para além da mera formalidade legal. Ferreira também argumenta que não é mais possível ser conivente com o silenciamento estatal sobre as desigualdades raciais, e que elas precisam ser combatidas e efetivamente enfrentadas. Apresenta o dado de que havia, naquele dia, no Congresso Nacional, 41 proposições sobre ações afirmativas e que, portanto, não era verdade que esse era um tema novo que requereria mais tempo, chamando a atenção para a urgência da ação do Legislativo.

Em oposição às opiniões favoráveis, a professora Yvonne Maggie apresentou seus argumentos. Iniciou sua participação lendo um cartaz exposto pela EDUCAFRO, que dizia "Não importa a cor, não importa a raça, só queremos dignidade, direitos da nossa Pátria" e afirmou concordar plenamente com ele. Contudo, explicou que se insurgia contra a proposta de cotas por acreditar que essa seja uma medida que divide a sociedade brasileira em raças.

Esse projeto vai dividir a Nação, legal e institucionalmente. Somos uma sociedade extremamente complexa e perversa, com enormes desigualdades. Mas não tínhamos, legalmente, distribuído direitos a partir do pertencimento a etnias e a raças. Ao contrário, a sociedade tinha como ideário a Nação de cidadãos. Isso não é pouco. É muito difícil. E com isso elegemos o negro figura jurídica de Direito pela 
primeira vez na história do Brasil (Yvonne Maggie, Audiência Pública Câmara dos Deputados 24/05/2006, p.24).

A professora afirma que a escravidão no Brasil não existiu como um sistema jurídico, e que, após abolida a escravidão, a lei brasileira se estabeleceu de modo arracial. Essa proposta, então, se apresentaria na contramão da tendência legislativa brasileira. A professora considera que, a partir dessa proposta, inicia-se a divisão de direitos sociais com o marcador racial, e que isso pode trazer sérios prejuízos para gerações futuras.

\subsubsection{4a Audiência Pública (18/11/2009) - Refletindo sobre as divergências}

A quarta e última audiência pública da Câmara dos Deputados a ser analisada neste trabalho foi a menor delas. Em novembro de 2009, o projeto de lei estudado neste trabalho já não tramitava mais na Câmara dos Deputados; ou seja, já havia ocorrido a votação no plenário dessa Casa e o mesmo já estava em andamento no Senado Federal. Ainda assim, essa audiência pública foi realizada pela Comissão de Direitos Humanos em parceria com a ouvidoria parlamentar da Câmara dos Deputados.

De acordo com o presidente da sessão, Deputado Pedro Wilson (PT/GO), a iniciativa da audiência pública era consequência de um pedido feito pelo Conselho de Defesa dos Direitos dos Negros e pela Secretaria de Justiça, Direitos Humanos e Cidadania do Distrito Federal à ouvidoria daquela Casa. Com o aceite do requerimento do Deputado Luiz Couto (PT/PB), a audiência pública foi convocada, sendo seu objetivo central discutir as cotas para negros nas Universidades públicas brasileiras.

Participaram da audiência pública representantes de movimentos sociais, de entidades acadêmicas e do Instituto de Pesquisa Econômicas Aplicadas (IPEA). Assim, como em algumas outras audiências, essa contou com todos os expositores favoráveis às cotas. A participação parlamentar nessa audiência pública foi menor do que nas outras. Note-se que o evento ocorre dias antes de 20 de novembro, data comemorativa importante para o movimento negro.

O principal ponto de destaque dessa audiência pública foi o posicionamento dos participantes favoravelmente às cotas raciais. Os argumentos centrais das exposições eram a 
diferenciação entre as cotas raciais e as cotas sociais, apresentando-se alguns argumentos e algumas discordâncias sobre o assunto.

\begin{abstract}
A adoção de cotas raciais é uma proposta que não foi digerida pela sociedade brasileira, tanto é que se coloca, todo o tempo, que é melhor, não sabemos para quem, que seja cota social (Jacira da Silva, Audiência Pública Câmara dos Deputados 18/11/2009, p.4).
\end{abstract}

As cotas têm a função, na verdade, de abrir um teto, para que uma elite negra possa se moldar como uma elite intelectual. As cotas - falei isso uma vez e sofri uma série de críticas, mas reafirmo - são para colorir uma elite que é pálida hoje em dia. A nossa elite é pálida em relação ao resto do País. As cotas vêm corrigir isso, vêm possibilitar que haja médicos, engenheiros, enfermeiros, profissionais liberais negros, como existem médicos e engenheiros brancos. As cotas são para isso. As cotas não são política social no sentido clássico da palavra, aquela que vai acabar com a desigualdade social. A cota vem como único instrumento para acabar com um fenômeno no Brasil que nunca sofreu contraposição: o fenômeno do racismo e da discriminação, que fecha portas (Mário Theodoro, Audiência Pública Câmara dos Deputados 18/11/2009, p.17).

Também se diz com muita frequência que melhor seriam cotas sociais e não raciais. Acho muito estranho esse termo, sabem por quê? Por que racismo é um fenômeno social; homofobia é um fenômeno social; misoginia é um fenômeno social. (...) Então, não sei como o racismo deixa de ser social, se é um problema que afeta a vida de milhões de pessoas, homens e mulheres no Brasil. Não entendo como o racismo não é uma questão social. Acho que seria melhor se disséssemos cotas baseadas na classe ou cotas baseadas na raça. Na verdade, quando se diz que é social, está-se falando de classe, e classe não é categoria absoluta (Nelson Inocêncio, Audiência Pública Câmara dos Deputados 18/11/2009, p.20).

Assim como em audiências públicas anteriores, foram apresentados dados e argumentos que se contrapunham aos posicionamentos contrários às cotas. A data em que essa audiência pública aconteceu foi importante por ser poucos meses após o DEM haver apresentado no Supremo Tribunal Federal a ação contra as cotas raciais da Universidade de Brasília. Na maioria das falas esse fato é mencionado, e indica-se a necessidade de aprofundamento da discussão sobre o tema.

\title{
3.3 AUDIÊNCIAS PÚBLICAS SOBRE COTAS NO SENADO FEDERAL
}

\subsubsection{1 $1^{a}$ Audiência Pública (18/12/2008) - Aumento da tensão: as disputas políticas estão à mesa}

Esta audiência pública ocorreu em uma das últimas sessões legislativas do ano de 2008. De acordo com os registros das notas taquigráficas, sua convocação se deu por que o Senado havia recebido há poucas semanas o projeto de lei e havia grande pressão para sua 
aprovação. Senadores favoráveis articulavam para a aprovação mais célere, ao passo que senadores contrários pediam mais tempo para discussão e amadurecimento da proposta. É uma característica dessa audiência a diversidade de opiniões sobre o assunto. Foram compostas quatro mesas de discussão com um representante favorável à proposta de cotas raciais e um representante contrário à proposta. Houve significativa participação de parlamentares, apesar de não ter acontecido um momento de apresentação de dúvidas e sugestões deles.

Com o objetivo de sistematizar melhor as informações desse evento, dividiremos em duas partes a descrição analítica. Primeiro, apresentaremos as informações trazidas pelos convidados favoráveis e contrários, e, em segundo lugar, trataremos das intervenções dos senadores e suas argumentações. Assim como feito anteriormente, centraremos a abordagem dessa audiência pública em torno de algumas ideias chave que tem guiado as discussões desse trabalho, sendo a tensão entre cotas sociais e cotas raciais a principal delas.

Para falar favoravelmente sobre o assunto foram convidados: André Lázaro (MEC); Frei David dos Santos (EDUCAFRO); Sérgio José Custódio (MSU) e Deise Benedito (UnB). Com exceção do MSU, as demais instituições haviam participado também das audiências públicas realizadas na Câmara dos Deputados. Para falar contrariamente sobre o tema foram convidados: Yvonne Maggie (UFRJ); Roberto Militão (AFROLUX); José Carlos Miranda (MNS) e Jerson César Leão Alves (MNM). Desses, apenas a professora da UFRJ já havia participado de audiências públicas anteriores no Congresso Nacional.

Adiante discutiremos com mais detalhes, porém, um dos aspectos mais relevantes dessa audiência pública são os novos atores institucionais que se somam ao debate. Até então, no debate legislativo, não haviam organizações sociais com debate racial que se manifestassem publicamente contrárias as cotas. As opiniões e contribuições trazidas por elas parecem apontar para dois caminhos: o de aprofundamento do debate sobre o mito da democracia racial, e também trazem elementos ainda não problematizados no trâmite legislativo dessa proposição como a classificação racial, por exemplo.

Entre os argumentos dos participantes favoráveis à política de cotas, apareceram principalmente a necessidade de se garantir o acesso e as oportunidades iguais; a apresentação de dados e relatos de experiência que enfatizavam o prejuízo histórico dos negros; e dados de experiências em trâmite que demonstravam que a qualidade universitária não era prejudicada pela implementação de cotas. Explicações sobre como as cotas não contribuiriam para um conflito racial e sobre sua constitucionalidade também foram muitas vezes apresentados. 
Nota-se também que havia uma preocupação estratégica entre os participantes favoráveis à proposta de que ela fosse aprovada como estava, sem alterações. Isso por que qualquer modificação de mérito implicaria em retorno do projeto de lei para a Câmara dos Deputados, o que significava mais tempo de tramitação.

Nesse sentido, então, mesmo reconhecendo que haviam modificações passíveis de serem feitas, os participantes pediam aos senadores que não alterassem o texto em questão para que a matéria fosse logo encaminhada à sanção presidencial e passasse a ser implementada. Frei David dos Santos afirmou:

Se houver mudança no texto terá que voltar à Câmara e será mais nove anos de espera e exclusão dos pobres, negros e índios das universidades federais. Mantenham o texto como está. Em um ano, poderemos mudar. Lembro a vocês, Senadores, que a nossa querida Constituição cidadã já sofreu em 20 anos mais de 40 emendas. A nossa Constituição já sofreu mais de 40 emendas. Por que esse projeto também não pode sair daqui imperfeito para ser aperfeiçoado como a Constituição foi aperfeiçoada? Lembro a vocês que a Lei de Cotas da UERJ, em cinco anos, já sofreu três mudanças. Mudar é normal (Frei David dos Santos, 18/12/2008, Audiência Pública Senado Federal).

André Lázaro (MEC) argumentou da seguinte forma:

Por fim, Srs. Senadores, eu creio que o projeto que está à Mesa para apreciação, naturalmente pode ser aperfeiçoado. Claro aqui é a Casa da Lei, e aqui se sabe que é preciso, é possível e é desejável que se revejam as leis com certa periodicidade e se avaliam seus impactos.

O que para nós do Ministério da Educação seria muito relevante e pediria aos Srs. Senadores uma contribuição nesse sentido é que aprovássemos ainda este ano, porque o Brasil vive hoje um momento muito positivo na educação e contamos com o apoio do Legislativo para isso (André Lázaro, 18/12/2008, Audiência Pública Senado Federal).

São as argumentações contrárias que trazem à discussão deste trabalho novos atores e possíveis caminhos para aprofundamento das análises sobre como se deu a construção da legislação no Congresso Nacional. Conforme anteriormente exposto, entre os quatro participantes contrários às cotas, três não haviam participado das mesas de discussões na Câmara dos Deputados, e ao que tudo indica alguns chegaram a participação nessa audiência por incentivo e indicação de senadores contrários à matéria. A narrativa seguida por essas organizações parece algo importante a ser destacado, os representantes da AFROLUX $^{53}$ e do

\footnotetext{
${ }^{53}$ Também referenciada como AFROSOL-LUX - Promotora de soluções em economia solidária. Não foram localizadas informações mais detalhadas sobre esta organização em sites de busca na internet. Há referência a essa organização em notícias que trazem manifestações contra cotas, o senhor José Roberto Militão é quem fala pela organização.
} 
$\mathrm{MNS}^{54}$ iniciaram suas participações contando sobre seus históricos de militância e participação social, e o seu não pertencimento a uma elite branca acadêmica, considerada a principal opositora às cotas. Em suas palavras:

Integro hoje a Afrosol-Lux, uma organização que visa a inclusão da população negra excluída de oportunidades econômicas através de programa de economia solidária, integrei a primeira ONG no Brasil que cuidou de levar (...) as centrais sindicais o compromisso de sindicalistas, de combaterem o racismo dentro das suas plataformas de reivindicação organizadas.

Portanto, eu não pertenço a uma elite branca que quer manter a população negra excluída. E é nessa qualidade aí como advogado há vinte anos estudando políticas de ações afirmativas que desde a época da Constituinte batalhei, participei de seminários e debates para que o Estado acolhesse no seu seio políticas de ações afirmativas (José Roberto Ferreira Militão, Audiência Pública Senado Federal 18/12/2008, p.26).

E gostaria de fazer essa discussão, não só como negro que sou, mas muito à vontade como um militante do Movimento Social pertencente desde 1981 ao Partido dos Trabalhadores, fundador da Central Única dos Trabalhadores, morador da cidade de Caieiras, uma cidade da periferia da grande São Paulo. (...) Eu não necessito do título de doutor porque eu só tenho o $2^{\circ}$ grau, portanto, eu não faço parte de nenhuma elite branca como pode ver a cor da minha pele e muito menos da minha origem social (José Carlos Miranda, Audiência Pública Senado Federal 18/12/2008, p.43).

A argumentação dos dois relaciona-se centralmente com a preocupação de que o país desenvolva relações sociais de ódio racial. O senhor José Roberto Ferreira Militão se diz favorável às ações afirmativas, mas contrário às cotas raciais. De acordo com ele, as cotas sociais seriam suficientes para os fins que a política pretende de minimização das desigualdades sociais. Demonstra, também, grande preocupação com o Estado legislar considerando o critério racial, em suas palavras:

quando o Estado adota raça e diz que raça é identidade jurídica, o Estado está legitimando, está pegando aquele ideal do racista de 1750 e querendo transformar isso em realidade do cotidiano da cidadania, e o Estado não pode fazer isso. A luta contra o racismo é destruir esse conceito da existência de raças humanas. A espécie humana deve ser tratada pelo Estado como tal. [...] Mas se o Estado legislar sobre raças daqui a 150 anos nós seremos um Brasil deplorável. Nós não temos o direito de fazer isso. Nós não recebemos um país com identidade jurídica racial, a nossa geração não recebeu esse país. Nós não temos o direito de entregar este País às futuras gerações divididas identidade jurídica de raça (José Roberto Ferreira Militão, Audiência Pública Senado Federal 18/12/2008, p.29).

\footnotetext{
54 Esta organização possui um endereço eletrônico acessível aqui: http://www.nacaomestica.org/. Conforme informações deste site, o Movimento Nação Mestiça foi fundado em 2001, e é "organização brasileira de mestiços que tem entre seus objetivos defender a etnia mestiça brasileira e seu povo, a valorização do processo de mestiçagem entre os diversos grupos étnicos que deram origem à nacionalidade brasileira, a promoção e defesa da identidade mestiça e o reconhecimento dos mestiços como herdeiros culturais e territoriais dos povos dos quais descendam."
} 
Argumentando logo em seguida que a possibilidade de replicação e disseminação de leis raciais pelas demais unidades da federação, inspiradas pela proposta nacional, seria um problema enorme para o país. Já o senhor José Carlos Miranda, convidado do senador Demóstenes Torres (DEM/GO), afirma que a raiz dos problemas sociais que o Brasil enfrenta é o abismo entre as classes sociais. Diz também que a discussão de cotas raciais nas universidades seria apenas a ponta do iceberg para a racialização das leis no país, o que vai contra princípios democráticos como o da igualdade e liberdade. Ao final conclui:

Está na mão de vocês evitar o pior, está em suas mãos recusar esse pretenso Estatuto da Igualdade Racial e esse Projeto de Lei de Cotas Raciais que vai lançar nossos netos, vossos filhos e vossos netos uns contra os outros trazendo um rio de dor e sangue, um país aonde homens e mulheres se orgulham de ser o produto de nossa própria história, filhas e filhos da raça humana. Vocês decidem se respeitam, de fato, o mandato que reivindicam, que receberam do povo ou se vão sujar as mãos de sangue, abrindo o Brasil para a sua racionalização e de um ódio racial que nunca aconteceu neste País (José Carlos Miranda, Audiência Pública Senado Federal 18/12/2008, p.48).

A professora Yvonne Maggie, opositora às cotas raciais, que já havia participado de outro debate legislativo, manteve sua mesma lógica de argumentação. O ponto central para essa expositora é o de que as cotas raciais criariam um país que distribui direitos a partir de critérios raciais, e assim potencializa a existência de conflitos raciais. Ela posiciona-se favorável às cotas sociais, com recorte de escola pública, já que nesse caso não haveria o abandono dos brancos pobres. Ela afirmou:

\footnotetext{
A minha pergunta é o seguinte: não teria sido mais simples reservar $50 \%$ de vagas para estudantes que cursaram integralmente o ensino médio simplesmente sem colocar a raça? Por que introduzir o critério raça para distribuição de justiça? O objetivo seria fazer justiça ou dividir o Brasil legalmente em brancos e negros para desviarmos do rumo que devemos seguir, o rumo da melhoria da qualidade do ensino básico para todos os brasileiros. (...) há, claramente, um desejo de fazer com que eles se conscientizem da sua raça, e é o Estado Brasileiro que assumiu a responsabilidade de impor ao povo brasileiro uma raça. E a última vez que nós tivemos isso não deu bom resultado. Nós sabemos que judeus não existiam dessa maneira antes do nazismo, eles foram uma construção (Yvonne Maggie, Audiência Pública Senado Federal18/12/2008, p.12).
}

O senhor Jerson César Leão Alves, representante do Movimento Nação Mestiça, enfoca sua argumentação em outro aspecto da problemática até então não tratado com tanta especificidade. Sua principal crítica ao projeto de lei está nas categorizações raciais estabelecidas neste projeto e no projeto do Estatuto da Igualdade Racial. De acordo com ele, há, no Brasil, em especial no norte do país, aqueles que se identificam como mestiços, cafuzo e caboclos, e que essas identidades têm sido negadas e suprimidas pela categoria pardo. Sendo que isso tem sido motivo de conflitos nos debates sobre as políticas públicas daquela região, em suas palavras: 
Então, o que eu estou colocando é que a nossa experiência como exclusão por discriminação por esses grupos na Amazônia faz com que nós possamos dizer para vocês com toda sinceridade, as cotas raciais não vão gerar conflito racial no futuro não, as cotas raciais já estão gerando conflito racial. (Jerson César Leão Alves, , Audiência Pública Senado Federal 18/12/2008, p.58).

Afirmou que sua organização poderia até admitir a existência de cotas sociais, mas que as cotas raciais, tais como expostas na lei, não eram uma boa opção para as relações raciais no Brasil, em sua opinião. Outro fato importante nas falas dessas organizações foi a manifestação contrária ou conflituosa com outros tipos de projetos de lei ou instituições vinculadas à temática racial. Ou seja, em quase todos os depoimentos apareceu a rejeição ao Estatuto da Igualdade Racial, bem como apresentaram discordância com a existência e atuação da SEPPIR/PR, note-se:

(...) no art. $6^{\circ}$ ele diz que quem vai ser o responsável para cuidar disso será a Secretaria Especial de Políticas de Promoção da Igualdade Racial, a Seppir. Ora, para a Seppir, e desde 2005 nós temos tido problemas com a Seppir, a Seppir segue essa lógica: preto e pardo são negros, então para a Seppir não existe política para caboclo, caboclo não existe, mulato não existe para a Seppir. Então, a lógica, se a pessoa chega lá e: não, me autodeclaro pardo. E daí a Seppir chega lá e está dizendo que ele é negro. Ora, eu, pessoalmente, eu tenho sangue de índio, eu tenho sangue de negro, eu tenho sangue de branco; eu sou um mestiço, eu tenho aparência de mulato, meu pai é um caboclo cearense. Agora a Seppir decidiu... Eles acham que podem dizer para mim o que eu sou, eu tenho cabelo branco, eu tenho 42 anos de idade e a pessoa acha que pode dizer para mim o que eu sou. Quer dizer é algo meio estranho. Que direito eu dei... Eu não me acho no direito de dizer para ninguém a sua raça, como a pessoa pode dizer para mim o que eu sou? É algo meio estranho (Jerson César Leão Alves, Audiência Pública Senado Federal18/12/2008, p55).

Se os nossos males aqui do racismo produzido, das discriminações é a marca e não a raça, a mim, pelo menos, é incompreensível que o Estado passe a criar Secretaria Especial de Promoção da Igualdade Racial num país em que a Academia me diz que raças não é identidade do povo. Isso é a Academia que me diz, a Academia há de me desmentir em relação a isso. (...) Então, é um remédio inadequado para um mal inexistente, e se é inadequado não é recomendável porque nós vamos mexer com a identidade da cidadania, a identidade futura, e quando se mexe com o futuro, Dr. André, há de se ter muito cuidado, há de se refletir que os efeitos colaterais demoram (...) (p. 30, José Roberto Ferreira Militão, Audiência Pública Senado Federal 18/12/2008, p.30).

Posto isso, passemos às informações sobre a participação dos senadores. Conforme anteriormente exposto, não houve nesta audiência pública um momento específico para que os parlamentares apresentassem suas opiniões dúvidas e sugestões. Contudo, ainda assim, entre as falas dos participantes, ou até mesmo durante as participações, algumas posturas puderam ser observadas a partir das notas taquigráficas. O senador com participação mais destacada nessa audiência pública foi Demóstenes Torres (DEM/GO), um dos principais antagonistas na tramitação da matéria na Casa. 
Logo na primeira fala da audiência pública, de Frei David, foi feita a referência à dura oposição do partido Democratas (DEM) e especialmente do senador Demóstenes Torres (DEM/GO) aos projetos de lei relacionados à população negra brasileira. A partir da terceira mesa, esse senador inicia sua participação na audiência fazendo diversas intervenções, inclusive interrompendo participantes favoráveis as cotas raciais. Pelas notas taquigráficas analisadas nota-se que a participação do senador geralmente levava a reunião a algum tumulto, e as vezes à discussões entre ele e convidados ou e entre ele e outros parlamentares.

O senador elogiou muito o discurso do senhor José Roberto Ferreira Militão (AfroLux), queixou-se ao representante do MEC que o governo queria aprovar a proposta sem discussão no Senado Federal, debateu com a senadora Fátima Cleide (PT/RO) sobre os posicionamentos dos partidos políticos em relação às cotas, se contrapôs a representante da Universidade de Brasília afirmando que sua fala continha ódio racial e afirmou que gostaria de pedir vistas ao projeto para apresentar uma proposta alternativa ao que estava em discussão. Sendo, portanto, notável a oposição que este parlamentar e seu partido faziam ao projeto de lei.

Outros senadores também se manifestaram na ocasião, conforme apresentado na Tabela 9 Aparentemente interessados na discussão e demonstrando preocupação com o bom andamento das discussões, destacam-se a senadora Marina Silva (PT/AC) e o senador Eduardo Suplicy (PT/SP), que, ao intervirem, apresentavam questões de ordem ou argumentações no sentido de possibilitar a adequada participação dos convidados. A senadora Ideli Salvatti (PT/SC), já ao final da audiência, tratou de um projeto de lei de sua autoria que tramitava em conjunto com o projeto discutido nesta data, afirmando que estava preocupada com o trâmite legislativo da matéria e que pediria àquela Comissão um pouco mais de tempo para análise e aprovação das matérias.

\subsubsection{2 a Audiência Pública (18/03/2009) - O principal conflito está exposto: as cotas raciais}

A segunda audiência pública do Senado Federal contou com a participação de dez expositores, com proporção igual de opiniões favoráveis e contrárias. Na ocasião, presidia a Comissão de Constituição e Justiça o senador Demóstenes Torres (DEM/GO). As notas 
taquigráficas informam que havia uma tensão entre os parlamentares. Por um lado, haviam aqueles que pediam para que as discussões fossem realizadas e logo em seguida fosse feita a votação para que a matéria pudesse seguir seu trâmite. Por outro lado, haviam aqueles parlamentares que preferiam continuar discutindo o tema.

Assim como na audiência pública anterior, a dinâmica dessa reunião se deu com alternância entre as participações favoráveis e contrárias. Diferentemente da primeira audiência pública do Senado Federal, nesta os senadores tiveram oportunidade de discutir a matéria apresentando suas dúvidas e considerações. Entre os participantes que falaram favoravelmente estavam: Willian Douglas (EDUCAFRO); Augusto Werneck (PUC-RJ); Daniel Cara (Campanha pelo direito à Educação ${ }^{55}$ ); Wellington Faria (MSU); Rosani Fernandes Kaingang (Fórum de Educação Indígena).

A participação dos convidados favoráveis a proposta reforçou argumentos já tratados em audiências públicas anteriores, com a apresentação de dados estatísticos, relatos de experiências pessoais e informações sobre os resultados dos programas de ações afirmativas já implementados pelo país. Tanto as cotas para escolas públicas como as cotas raciais foram defendidas por esses participantes, que fizeram referência ao histórico de desigualdades sociais e raciais do Brasil, bem como a possibilidade de construção de um novo futuro possível a partir daquela matéria. A maioria das falas reconheceu que as cotas não eram uma medida suficiente para a solução total das desigualdades, mas sim um passo necessário nesse processo.

Conforme dito, os argumentos favoráveis utilizados nessa audiência pública já repetiam a essência dos que foram utilizados nas cinco audiências públicas anteriores. Contudo, vale destacar a participação da senhora Rosani Kaingang, representante do Fórum de Educação Indígena. Pela primeira vez em todo esse processo uma representante da população indígena foi ouvida pelos parlamentares. Em sua participação, ela defendeu a existência de cotas raciais, remetendo ao passado colonial e de genocídio da população indígena, e ao presente, em que o Estado ainda não oferece boas condições para seu o pleno desenvolvimento. Ao tratar das cotas nas universidades afirmou:

\footnotetext{
${ }^{55}$ Campanha Nacional pelo Direito à Educação é uma organização fundada em 1999, que articula uma ampla rede de grupos e entidades ligados ao campo da educação. Conforme seu site, "A missão da Campanha é atuar pela efetivação e ampliação das políticas educacionais para que todas as pessoas tenham garantido seu direito a uma educação pública, gratuita, inclusiva, laica, e de qualidade no Brasil”. Mais informações disponível em: <http://campanha.org.br/quem-somos/a-campanha/>.
} 
(...) podemos concluir que é crescente e notória a demanda dos nossos povos por ensino superior, nas mais diversas áreas do conhecimento. Ingressar nas Universidades Públicas, para nós é a possibilidade de articular o conhecimento dos nossos povos com os demais conhecimentos, para elaboração de estratégias de enfrentamento dos problemas e obstáculos impostos pelas políticas que nem sempre contemplam as diversidades culturais dos povos indígenas. Como, por exemplo, uma forma de resistir a drástica redução dos nossos territórios, as frequentes invasões das nossas terras por empreendimentos econômicos como: barragens, rodovias, ferrovias, linhas de transmissão de energia, que derrubam as nossas matas, inundam nossas aldeias e, principalmente, resistir contra essa instabilidade na garantia dos direitos já conquistados, que são constantemente questionados, ameaçados, e, por que não dizer, negados em favor de interesse de grupos econômicos, de elites brasileiras que têm interesse, sim, na riqueza dos nossos territórios.

(...) Estamos aqui, sim, sobrevivemos, queremos estar nas Universidades Públicas, para voltar para nossas comunidades, para valorizar mais nossas culturas, para ser, sim, referenciais na discussão dos direitos indígenas. Nós queremos ser protagonistas, não queremos mais ser somente alvo das Políticas Públicas (Rosani Kaingang, Audiência Pública Senado Federal 18/03/2009, p. 35).

Como nota-se, a participação da representante do Fórum de Educação Indígena traz à discussão temas muito importantes, como por exemplo que a apropriação dos conhecimentos acadêmicos juntamente com os conhecimentos tradicionais pode oferecer a suas populações de origem condições de vida muito melhores. A emancipação política, a produção de políticas públicas a partir dos próprios sujeitos beneficiários são outras reflexões importantes trazidas nessa participação. Sendo assim, consideramos extremamente relevante a participação de representante indígena nesse momento da discussão, que enriqueceu os argumentos favoráveis utilizados nas audiências públicas com uma nova perspectiva sobre o assunto.

Entre os participantes contrários estiveram presentes: Demétrio Magnoli, Hederli Alves (Movimento Nação Mestiça); Francisco Silva (FORAFRO); Vera Fávero (Movimento Negro Socialista ${ }^{56}$ ) e Bolívar Lamounier (USP). Assim como os representantes favoráveis a matéria, os representantes contrários apresentaram argumentações que se repetem em relação ao cerne das discussões em audiências públicas anteriores. A maioria deles afirma ser favorável às cotas sociais, aquelas de escolas públicas, que de acordo com os entendimentos apresentados seriam uma solução para diminuição das desigualdades sociais. O ponto de discordância principal, muitas vezes o único ponto de discordância, era em relação às cotas raciais.

A maioria das falas apontava para a possibilidade de se criar um clima de ódio racial inexistente no Brasil até então, e também o risco que era o país passar a legislar considerando

56 O Movimento Negro Socialista possui um blog, que pode ser acessado pelo link: <http://www.mns.org.br/node/3>. Há neste blog um texto chamado "Uma crítica marxista da proposta das cotas raciais", em que são apresentados sua argumentação contra as cotas raciais. 
o critério racial. O Movimento Negro Socialista afirmou que o foco do debate sobre desigualdades deveria ser às classes sociais, e que o tratamento do critério racial dividia a verdadeira luta, que era a luta de classes. A ONG Nação Mestiça (movimento nação mestiça) e o FORAFRO, ambos da região norte do país, afirmaram que já estão ocorrendo no país conflitos raciais em decorrência do não reconhecimento dos mestiços como uma categoria racial. Conforme haviam afirmado em sua participação na audiência pública anterior, a questão principal desses dois grupos diz respeito a como o Estado tem definido as categorias raciais, desconsiderando as preferências pessoais de autoclassificação.

Nessa audiência pública também ficou evidente a discordância desses grupos com a existência e atuação da SEPPIR/PR que, de acordo com suas ideias, seria uma secretaria para promover interesses específicos e ideológicos. Os acadêmicos Demétrio Magnoli e Bolívar Lamonieur, que também participaram como convidados contrários às cotas, expuseram alguns exemplos internacionais. Segundo o professor Magnoli, seria possível comparar o caso do país africano Ruanda com a proposta em trâmite, por exemplo. Ambos são radicalmente contra as cotas raciais por acreditarem que existe no país um povo brasileiro que não caberia dentro das categorizações raciais que estavam sendo proposta por essa legislação.

A grande preocupação dos intelectuais é com a criação de conflitos raciais no país, como consequência de leis como esta que estava em discussão. De acordo com sua linha de raciocínio inevitavelmente esse tipo de lei daria origem a uma competitividade entre os pobres, negros e brancos. E essa competitividade maior levaria ao acirramento das relações e a conflitos raciais, segundo eles que inexistentes no país até então. Assim afirmou o professor Lamounier:

Aqui no art. $3^{\circ}$ [do projeto de lei] está se propondo adotar a figura jurídica raça como critério de política pública no Brasil, coisa que nós não temos há mais de um século, graças a Deus, não temos e eu espero que não venhamos a ter, porque seria uma tragédia para o Brasil como nação se nós de repente a pretexto de resolver um problema que já se vem resolvendo, bem ou mal, na prática, o Datafolha mostrou que o preconceito está diminuindo, a pretexto, ou fascinados ou seduzidos pela miragem de que por este caminho estamos resolvendo um problema, vamos criar um muito pior, que é a racialização no Brasil, o ânimo, às vezes, bastante acalorado das discussões que eu tenho visto pelo Brasil afora em torno dessa matéria já são uma indicação do que nós vamos ver, num prazo relativamente curto, se em cada escola, em cada Universidade, em cada exame vestibular e daqui a pouco em cada emprego público, porque isso aqui é um começo, em cada empresa, alguém tiver que decidir quem tem o privilégio, o benefício da reserva de vagas, e quem não tem. Nós vamos ver conflitos muito sérios.

[...]do ponto de vista do precedente jurídico é gravíssimo nada mais nada menos, do que a racialização, um começo de racialização do Direito Brasileiro. É a criação de uma figura que nós não tivemos na nossa história republicana. Em nenhum momento, se adotou, em nenhum Governo, nenhum regime, nem mesmo nas ditaduras a ideia de que raça pudesse servir como critério para Políticas Públicas. Certamente não em educação, não sei se em alguma, quero crer que nenhuma, 
nenhum Governo usou (Bolívar Lamounier, Audiência Pública Senado Federal $18 / 03 / 2009$, p.38 e 39$)$.

Os parlamentares que participaram da audiência estão descritos na tabela 9. Nessa audiência pública houve um espaço um pouco maior para participação dos senadores. Sendo que é possível observar pelas notas taquigráficas que parlamentares filiados ao PT, ao falarem, pediam pelo encaminhamento da votação do projeto, afim de que ele continuasse seu percurso legislativo e não se mantivesse naquela Comissão. O senador Demóstenes Torres (DEM/GO), conforme observado desde a audiência pública anterior, foi um dos principais antagonistas da matéria.

Nessa data, o senador Demóstenes Torres era presidente da Comissão de Constituição e Justiça e conduziu os trabalhos dessa audiência pública. Após a apresentação dos convidados, entre a participação de outros senadores, ele expôs o seu posicionamento contrário às cotas raciais. Pelo que foi possível entender de sua argumentação, os dados do IBGE, por agruparem pretos e pardos na categoria negros, o fazem de modo tendencioso. Ele defende que as cotas para escolas públicas existam, mas as raciais não, essas incitariam o ódio racial no Brasil.

\begin{abstract}
O que há na realidade com o número, digamos assim, de negros, quando eu era menino nós chamávamos de pretos e depois veio uma substituição para a palavra negro, porque preto era uma palavra, politicamente, incorreta, era discriminatória. Mas é o que o IBGE usa. Então, o grande truque, digamos assim, estatístico, é que nós temos no Brasil menos de $5 \%$ de pretos, segundo o IBGE, estou usando a termologia do IBGE. Nós temos aí em algo em torno de 46, 47\%, ou menos um pouco de pardos, $42 \%$ e resto antes de brancos. O que é um pardo? O que é um mestiço? Como eu sou, como V.Exa. é, como muitos somos, a grosso modo. Meio branco e meio negro, então é isso que nós somos. Se nós pegarmos tudo isso e concentrarmos, jogarmos os número de pretos, vai dar mais de $50 \%$, se nós jogarmos no número de brancos, vai dar mais de $90 \%$. Então, estatisticamente o IBGE fez isso, transformou, passou o pardo junto com o preto tem um nome: negro. Quando nós entendemos que negro, quem é o negro? É o antigo preto, que era chamado de preto. " (Demóstenes Torres, Audiência Pública Senado Federal 18/03/2009, p.50 e 51 grifo nosso)
\end{abstract}

Outro senador que parece importante de ser destacado nessa parte é o senador Lobão Filho (PMDB/MA), filho da deputada Nice Lobão (PSD/MA), autora do projeto de lei inicial. Ele afirma que o projeto original de sua mãe previa apenas as cotas sociais, e que a questão racial entrou depois na tramitação. Afirma ainda que os efeitos práticos dessa lei seriam insignificantes, pois as universidades públicas já são compostas por cerca de $50 \%$ de estudantes oriundos de escolas públicas, bem como, segundo ele, não ingressariam mais pretos, pardos e indígenas em decorrência da lei. Em suas palavras: 
Então, do ponto de vista prático de aplicação da lei, para os indígenas, por exemplo, não irá afetar nada. Para os pardos e negros, eu tive uma conversa aqui com o Senador Wellington, dificilmente, irá alterar a proporção vigente hoje nas Universidades também. (...) Eu acho que o conceito fundamental que devia ter sido discutido aqui, desde o princípio, é que vamos destinar $50 \%$ das vagas das Universidades Públicas Federais para as escolas públicas. E eu acho que isso é um grande avanço, um grande avanço da sociedade brasileira. Nós ficamos nos batendo na questão racial, racial, racial, quando se nós analisarmos friamente, o impacto será mínimo, mínimo (...) (Lobão Filho, Audiência Pública Senado Federal18/03/2009, p.50).

Ao final, o presidente da Comissão afirmou que seria realizada uma nova audiência pública, pois havia pedidos por parte do Ministro da SEPPIR/PR e de representantes de reitores das universidades públicas que gostariam de manifestar-se sobre o assunto. Portanto, a segunda audiência pública do senado federal caracterizou-se pela paridade de argumentações entre os convidados. Entre os parlamentares, a maioria apresentava concordância em relação às cotas sociais, mas resistência às cotas raciais. Os posicionamentos diversos dão a justa medida do nível de disputa política que o projeto de lei representava.

\subsubsection{3a Audiência Pública (02/04/2009) - Última audiência pública: há divergências entre os ideais de Brasil}

A última audiência pública sobre o assunto no Senado Federal contou com a participação de instituições como a SEPPIR/PR, o IBGE, representantes de universidades públicas, da União Brasileira dos Estudantes Secundaristas (UBES) e de reitores, conforme informa a tabela 9. Outro fato que chama atenção neste evento foi a participação de mais senadores, tanto opinando sobre o assunto como pressionando a presidência da Comissão para colocar a proposta em votação. Essa audiência, diferentemente das anteriores, ocorreu misturada com sessões de votação de outras matérias da Comissão.

Sendo assim, as notas taquigráficas desse dia trazem primeiro a apresentação de proposições não relacionadas às cotas, logo em seguida inicia-se a participação do Ministro da SEPPIR/PR e senadores fazem indagações a ele. Após a discussão e deliberação de outros assuntos, retoma-se a audiência pública com os demais participantes. Ao que tudo indica, o tema já estava bastante amadurecido no Congresso Nacional, pelos anos de tramitação e também pelas muitas audiências públicas já realizadas. Parece que essa última audiência ocorreu por que haviam instituições que desejavam se posicionar, mas ainda não haviam tido oportunidade de fazê-lo no Senado. Então, essa oportunidade foi concedida, mas ficou 
evidente como o evento foi conturbado pela existência de outros assuntos em pauta e, também, que os parlamentares já tinham sua opinião formada sobre o tema.

A primeira participação foi do Ministro da SEPPIR/PR, Edson Santos, que iniciou sua fala retomando as diferenças históricas de tratamento que o Estado brasileiro concedeu a brancos e negros, como por exemplo, na concessão de terras. A seguir relembrou as políticas raciais que vieram sendo implementadas a partir da redemocratização do país, apresentou a assinatura a tratados internacionais como um avanço e uma responsabilidade do Brasil que passou a comprometer-se por exemplo com a implementação de ações afirmativas, e também se referiu ao PROUNI como uma política de cotas que poderia servir de exemplo de sucesso para guiar a aprovação da Lei de Cotas.

Logo após a participação do Ministro, os senadores Ideli Salvatti (PT/SC), Aloizio Mercadante (PT/SP) e Paulo Paim (PT/RS), todos filiados ao PT, questionaram alguns aspectos do trâmite legislativo da proposição. Reclamaram sobre medidas protelatórias que estavam sendo utilizadas na tramitação, e pediram que o projeto de lei fosse votado pela Comissão ainda naquela sessão.

E eu quero, aqui, lamentar, porque, quando fizemos o acordo, o projeto já estava
emprestado aqui para a Comissão. Então, veja bem, o acordo feito, não nos foi dada
ciência de que havia o requerimento [no Plenário], de que o projeto estava apenas
emprestado, e o que eu tenho a lamentar mais ainda é o seguinte, para que nós
possamos apreciar o projeto, apensando o projeto do Senador Marconi Perillo ao
projeto que nós estamos aqui debatendo, é um projeto, que (...) poderia muito bem
ter sido apresentado aqui na forma de emendas, nós poderíamos debater. (...) Então,
a sensação que me passa é de que a apresentação do Requerimento para que o
projeto seja apensado, o fato de não ter sido dada ciência à Comissão é nada mais,
nada menos do que, do meu ponto de vista, uma tentativa de que nós não
deliberemos um assunto que, há tanto tempo, nós estamos aguardando (Ideli
Salvatti, Audiência Pública Senado Federal $02 / 04 / 2009$, p.8). Queria, Sr. Presidente, primeiro me associar à intervenção da Senadora Ideli, que a gente retire qualquer manobra protelatória desse tema e faça o debate com profundidade, com transparência, com coragem, quem é contra, quem é a favor. Acho que é isso que o Brasil espera do Senado e é para isso que nós fomos eleitos. Acho que a ideia de protelar um tema como esse não ajuda o processo, é desnecessário. As audiências não têm o papel protelatório, é de aprofundamento do mérito. Essa é uma matéria polêmica e sensível, foi assim historicamente em muitos países e será assim no Brasil, mas vamos fazer o debate com profundidade (Aloizio Mercadante, Audiência Pública Senado Federal 02/04/2009, p.11)

Não entendi também, Sr. Presidente, confesso, o projeto ora apresentado pelo Senador Marconi Perillo. Por quê? Porque eu fui Relator do projeto da Senadora Ideli Salvatti e acatei todas as emendas do Senador Marconi Perillo (...) (Paulo Paim, Audiência Pública Senado Federal 02/04/2009, p.12).

Após esses questionamentos, o senador Demóstenes Torres (DEM/GO) informou que também havia sido surpreendido pela apresentação de requerimento de apensamento de um novo projeto pelo senador Marconi Perillo (PSDB/GO) e que, nesse caso, avaliaria quais eram 
os procedimentos necessários para que a votação se desse de modo célere. Em seguida, informou haver feito uma ligação telefônica para o senador Perillo (PSDB/GO), e que ele viria à Comissão explicar sua proposta. Outros parlamentares se manifestaram sobre o projeto da Lei de Cotas, e favoravelmente às cotas raciais falaram a senadora Lucia Vânia (PSDB/GO), o senador Pedro Simon (PMDB/RS), a senadora Marina Silva (PT/AC), o senador Renan Calheiros (PMDB/AL). Fizeram perguntas sobre o período de duração da política, sobre o modelo de seleção por vestibular, entre outras, os senadores: Antônio Carlos Valadares (PSB/SE), Romeu Tuma (PTB/SP) e Marco Maciel (DEM/PE).

No meio dos questionamentos dos senadores ao ministro Edson Santos, o senador Marconi Perillo (PSDB/GO) chegou à audiência e explicou seu requerimento e sua proposta.

Sr. Presidente, Sras. e Srs. Senadores, eu apresentei um requerimento, embasado no
Regimento e na Constituição, requerendo que o Projeto de Lei do Senado, de minha
autoria, 344/2008, que institui reserva de vagas nos cursos de graduação das
instituições públicas de educação superior, pelo período de 12 anos e de forma
gradativa, pudesse tramitar conjuntamente ao Projeto de Lei da Câmara $\mathrm{n}^{\circ}$.
180/2008, que versam, na minha opinião, sobre a mesma matéria. Infelizmente,
antes que eu chegasse aqui, Sr. Presidente, alguns colegas chegaram a afirmar que
este requerimento pudesse tratar-se de uma manobra, no sentido de protelar ou
postergar a votação desse projeto. Isso não existe. As pessoas que eventualmente
possam ter pelo menos se referido a este assunto, mesmo sem que fosse de má-fé,
não tem o menor conhecimento da real intenção desse requerimento. Quando
apresentei o projeto, apresentei convencido de que, mais importante até do que
termos a reserva de cotas raciais para o ingresso de estudantes nas universidades, é
mais importante que as cotas sejam sociais. [...] Um projeto se complementa ao
outro. Nós não podemos discriminar o estudante branco pobre, em relação ao
estudante negro pobre (Marconi Perillo, Audiência Pública Senado Federal
$02 / 04 / 2009$, p.16).

O Ministro Edson Santos, atenciosamente, respondeu a cada questionamento e agradeceu a oportunidade de participação da discussão em curso no Senado Federal. O presidente da comissão explicou que, por haver um pedido de requerimento de apensamento na mesa do Plenário, a Comissão de Justiça só poderia discutir e votar a matéria quando o pedido à mesa fosse acatado ou rejeitado, e assim o projeto voltasse a Comissão. Logo após, discussões e votações de outros assuntos tomaram conta da pauta. Algum tempo depois, a audiência pública foi reiniciada com os outros participantes.

Foram realizadas, então, mais cinco apresentações, sendo duas favoráveis às cotas, inclusive às cotas raciais, e três contrárias. O representante da UBES, Ismael Cardoso, e o pesquisador do Laboratório de Políticas Públicas da UERJ, Renato Ferreira, fizeram suas exposições favoráveis ao projeto de lei. Ambos reforçaram os argumentos históricos que justificam a existência de cotas sociais e raciais, informando que as discussões e estudos de suas organizações de origem os conduzem a defesa dessas medidas. Renato Ferreira 
apresentou dados nacionais que contrariam as argumentações de que o ingresso de estudantes cotistas reduziria a qualidade da educação superior ou aumentaria os conflitos raciais. Ismael Cardoso destacou a atuação conjunta do movimento estudantil e do movimento negro no sentido de democratizar o ensino superior brasileiro.

Para falar contra a proposição em trâmite no Congresso Nacional, participaram da audiência pública José Roberto Pinto Góes, professor e historiador da UERJ, Amaro Lins, então Reitor da Universidade Federal de Pernambuco (UFPE) e Presidente da Associação Nacional dos Dirigentes das Instituições Federais de Ensino Superior (ANDIFES), e Simon Schwartzman, ex-presidente do Instituto Brasileiro de Geografia e Estatística (IBGE). Destacaremos partes das participações desses participantes que parecem importantes para a reflexão sobre quais argumentos estavam em pauta na discussão.

O professor e historiador da UERJ, José Roberto Pinto Goes, tratou de alguns argumentos históricos que constantemente são articulados na defesa das ações afirmativas, em especial das cotas raciais. De acordo com ele, é uma característica do Brasil o processo de miscigenação racial e ele discorda dos que acreditam que essa miscigenação seja fruto de relações de violência sexual. Segundo ele, a mestiçagem se deu muito mais a partir de relações livremente constituídas. Fez algumas críticas à decisão do Conselho Nacional de Educação (CNE), que produziu o documento de Diretrizes Curriculares Nacionais para a Educação das Relações Étnico-Raciais e para o Ensino da História e Cultura Afro-brasileira e Africana. Em suas palavras:

\begin{abstract}
Ora, eu tenho escutado aqui que a introdução do sistema de cotas nas universidades brasileiras não tem gerado ódio racial e que a nossa juventude continua convivendo como sempre, sem ódios raciais. Eu acho que isso é verdade. Eu sou professor da UERJ, eu vejo isso. Mas isso acontece porque nós não somos um povo racista. Agora, esse tipo de iniciativa aí, de ensinar as crianças que, quanto aos equívocos de uma identidade humana universal, e aplicar esse tipo de pedagogia do medo e do temor e do ódio, isso aí é complicado. Isso aí pode fazer das gerações, dessa garotada aí, pessoas diferentes do que foram seus antepassados. Essa é uma pedagogia racialista. Mas a gente não deve se enganar. Aonde quer que o ordenamento jurídico tenha acolhido a ideia de raça, em qualquer lugar do mundo, a pedagogia foi a da dor e a do medo (José Roberto Pinto Goes, Audiência Pública Senado Federal, 02/04/2009, p.35, grifo nosso).
\end{abstract}

Como revelam as notas taquigráficas, o historiador acredita que essa lei, se aprovada, será a primeira lei racial da história republicana do país, e desacredita que no pós-abolição o país tenha adotado uma política de eliminação física e simbólica da população afro-brasileira. Sua argumentação contrária às cotas foi em torno disso. O representante da ANDIFES, após apresentar dados sobre a expansão do ensino superior realizada pelo REUNI, afirmou 
preocupação com o projeto de lei em trâmite, que, em sua opinião, violava o princípio da autonomia universitária. Apresentando, portanto, posicionamento contrário à matéria

Então, nesse debate, tão qualificado, eu gostaria de colocar a posição das universidades federais, que nós somos contrários à aprovação de um projeto passando por cima da autonomia das nossas instituições. Essa autonomia, ferida uma vez, abre espaço para que várias outras ações possam por abaixo tudo aquilo que foi construído, um patrimônio da sociedade brasileira, que são as nossas universidades federais, que tem dado contribuições fundamentais para a geração do conhecimento novo, para a formação de milhões de jovens em todo o país. (Amaro Lins, Audiência Pública Senado Federal 02/04/2009, p.38).

As opiniões contrárias mais incisivas desse dia vieram do ex-presidente do IBGE, que afirmou que a discussão sobre cotas desviava a atenção de assuntos realmente importantes ao se tratar de educação. Sua argumentação centrou-se em discutir a deficiência do ensino médio e a precariedade das políticas de permanência no ensino superior. Em sua opinião, o aumento de vagas proposto pelo REUNI e a abertura de cursos noturnos, por exemplo, deviam ser pensados juntamente com a construção de novos currículos e adaptação do ensino ao novo público que irá alcançar as universidades. Tratou do PROUNI como uma experiência exitosa, que deveria ser muito valorizada por se tratar do ensino privado, onde se concentram a maior quantidade de vagas do ensino superior.

Destaca-se de sua participação alguns dados e cálculos que apresentou com o objetivo de refletir sobre o projeto de lei em debate. De acordo com o pesquisador:

O setor público [Universidades Públicas] já vem incorporando alunos de baixa renda. Assim como ele já vem incorporando alunos provenientes de escola pública. E a terceira coisa que eu queria mostrar é o dado por cor declarada, e aí eu tenho branco, oriental, contrastado com preto ou pardo ou indígena. A proporção também é relativamente grande, no setor particular, como no setor público, nós temos aí algo da ordem de $20 \%$ ou $30 \%$ já são assim. (...) A raça ou cor não é, então, o principal fator de desigualdade no ensino superior público. $30 \%$ dos alunos do ensino superior público hoje em dia..

Aqui eu falo público, pegando Federal e Estadual, porque o dado do IBGE aqui não distingue isso. Ele fala público ou privado. 30\% vem de escolas públicas, $35 \%$ vem de famílias de até 1,5 salário mínimo e 38\% são de cor preta, parda ou indígena. Esse é o dado da pesquisa nacional por amostra de domicílios - 2007. Eu fiz umas contas aqui, eu não vou entrar muito em detalhes, mas eu simplesmente fiz uma espécie de cálculo, dada distribuição. (...) Isso aqui é simplesmente uma estimativa para ter uma ideia de grandeza. (...) Hoje em dia, nós temos ali que, digamos, 30\% mais ou menos são hoje brancos de renda alta e vem de escola particular, e depois os outros segmentos. Os não-brancos de renda baixa e de escola pública já são algo como $15,16 \%$ hoje no sistema público. Bom, se eu mexer e introduzir cotas e mexer nessas personagens, a pergunta é a seguinte, quantas pessoas vão ser acrescentadas e quantas pessoas vão ser afastadas? Eu fiz duas hipóteses. Uma hipótese é interpretando a proposta da lei, dizendo o seguinte: As cotas são só para negros, pardos ou indígenas e exclui os brancos. É uma interpretação da lei. A outra coluna, que é essa última, 
(...) pensa que $50 \%$ é para pessoas mais pobres, independente da cor. (...) As duas me dão o quê? Na hipótese mais radical, digamos que eu estou excluindo os brancos das cotas, mesmo que tenham renda baixa, eu vou ter 200 mil pessoas beneficiadas no sistema Federal. (...) E, com isso, vou estar deslocando cerca de 120 ou 130 mil pessoas, inclusive pobres (...) digamos, como 50 mil, 70 mil pessoas, que são pobres e que vão ser discriminadas porque elas não vêm de escola pública, estudaram em escola particular ou porque elas são brancas. Então, isso é o resultado dessa política. Supondo evidentemente o que você vê é estático, supondo que é isso que está acontecendo (p.41, Simon Schwartzman, Audiência Pública Senado Federal 02/04/2009, p.41).

Desse modo, como nota-se, a preocupação do expositor era com a quantidade de estudantes brancos da rede de ensino básico particular que seriam 'discriminados' pelo projeto de lei em discussão. De acordo com ele, todos os critérios da Lei já estavam de alguma forma incluídos no ensino superior, então, tanto estudantes de escolas públicas, ou de baixa renda, ou estudantes negros conseguiam ingressar no ensino superior. E, que se alguma cota fosse implementada, a única admissível seria a cota social, uma vez que, no caso da cota racial, não havia critério objetivo para seleção.

A última audiência pública sobre o tema foi mais conturbada do que as demais, no sentido de que se sobrepuseram temas alheios ao debate das cotas durante o evento. Contudo, notou-se também que, na ocasião, já havia maior maturidade no debate feito pelos parlamentares, que já apresentavam seus posicionamentos. As apresentações novamente se deram de modo paritário, sendo que foram seis participantes: três favoráveis e três contrários às cotas. Destacamos nessa última audiência principalmente as argumentações contrárias que vão da negação do racismo ao cálculo das desvantagens que pessoas brancas teriam no acesso ao ensino superior com a aprovação da lei.

\subsection{CONSIDERAÇÕES FINAIS SOBRE AS AUDIÊNCIAS PÚBLICAS SOBRE COTAS NO CONGRESSO NACIONAL}

A análise das audiências públicas abriu a possibilidade de se obter informações complementares à análise da tramitação legislativa do projeto de lei que deu origem à Lei 12.711/2012. Como se sabe, uma das limitações da análise documental tal como feita neste trabalho para a tramitação da matéria é a rigidez dos dados, faltando informações sobre as emoções ou a intensidade das discussões naqueles momentos. Apesar de não ser possível neste trabalho analisar a fundo as relações intersubjetivas que se deram nas audiências 
públicas, buscou-se fazer a descrição dos eventos com uma quantidade de detalhes que contextualizam e evidenciam as tensões e os momentos de maior intensidade dos debates.

A partir das notas taquigráficas das audiências públicas também é possível observar de modo mais consistente a frequência dos argumentos e quais eram os principais defensores e opositores à proposta. Entre os principais argumentos favoráveis, destacamos: a possibilidade de garantia de acesso e oportunidades iguais; uma reparação aos prejuízos históricos da população negra e o reconhecimento do critério de raça como real na distribuição de oportunidades; uma possibilidade de se reduzir desigualdades sociais; resultados de pesquisas que indicavam que cotas não reduzem a qualidade das universidades; cotas como medidas temporárias com o objetivo de promover a diversidade e inclusão racial/étnica; e, por fim, defendeu-se a constitucionalidade das cotas.

Entre os principais argumentos contrários, apresentaram-se as questões da divisão do país em raças ou a racialização da distribuição de direitos como consequência da implementação; a defesa de que medidas universalistas teriam o mesmo efeito; a não objetividade das categorias raciais, já que não existem limites rígidos entre elas; a marginalização de parte da população, a parcela branca pobre; o rompimento com uma ideia de povo/nação brasileira; o aprofundamento dos conflitos e do ódio racial; e, por fim, a criação de uma identidade jurídica baseada na raça.

Apenas para expor de modo mais sistemático informações sobre o reconhecimento ou não da discriminação e do preconceito nas casas legislativas durante as audiências públicas, apresentamos as redes ${ }^{57}$ abaixo:

\footnotetext{
57 As falas das audiências públicas também foram processadas por meio do software ATLAS de análise qualitativa de dados. Quando o trabalho cita as principais argumentações favoráveis e contrárias se baseia em resultados extraídos do processamento das informações pelo software.
} 


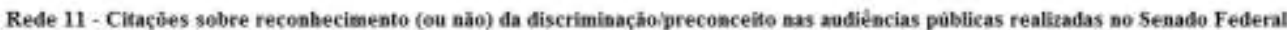
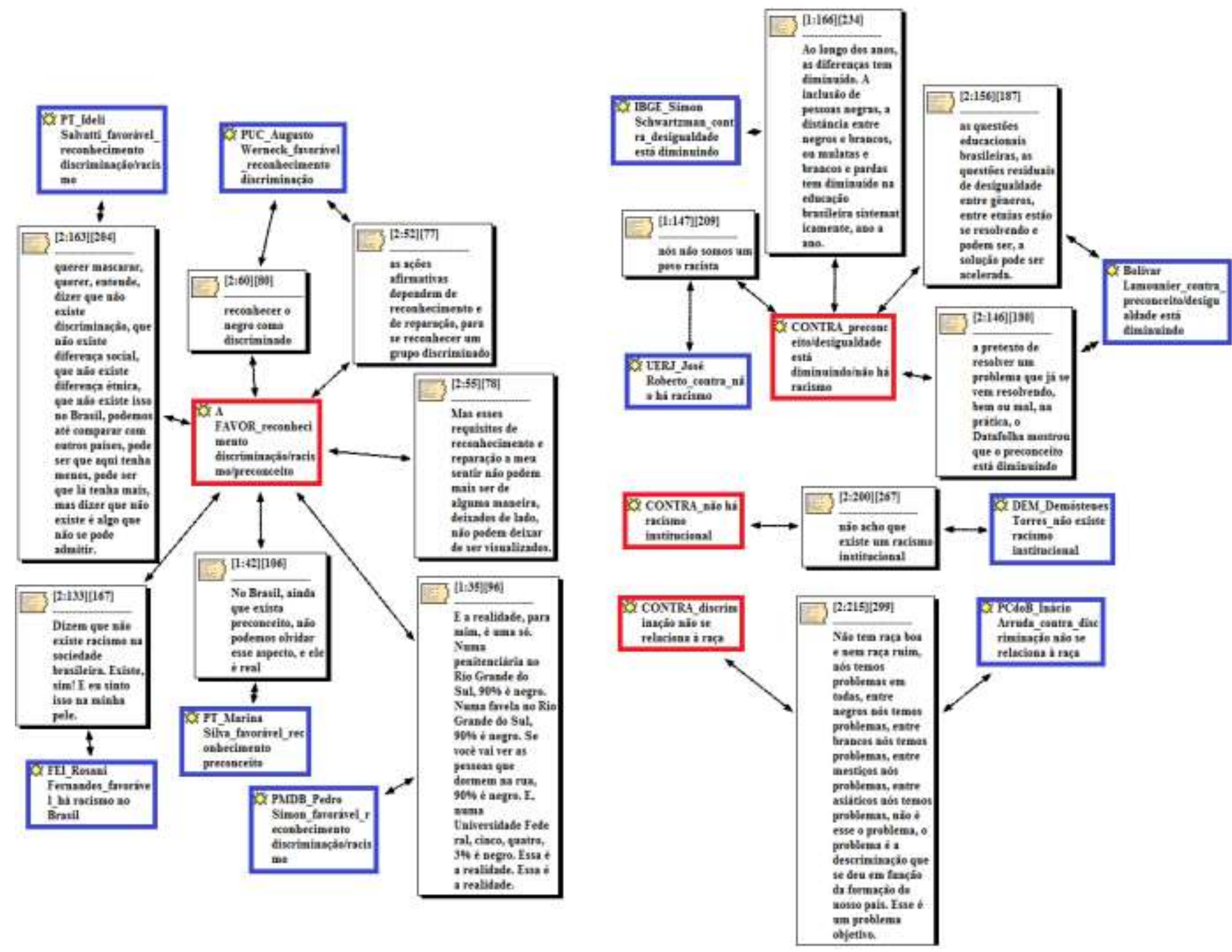
Rede 12 - Citaçôes sobre reconhecimento da discriminaçào/racismo nas audiências públicas realizadas na Câmara dos Deputados

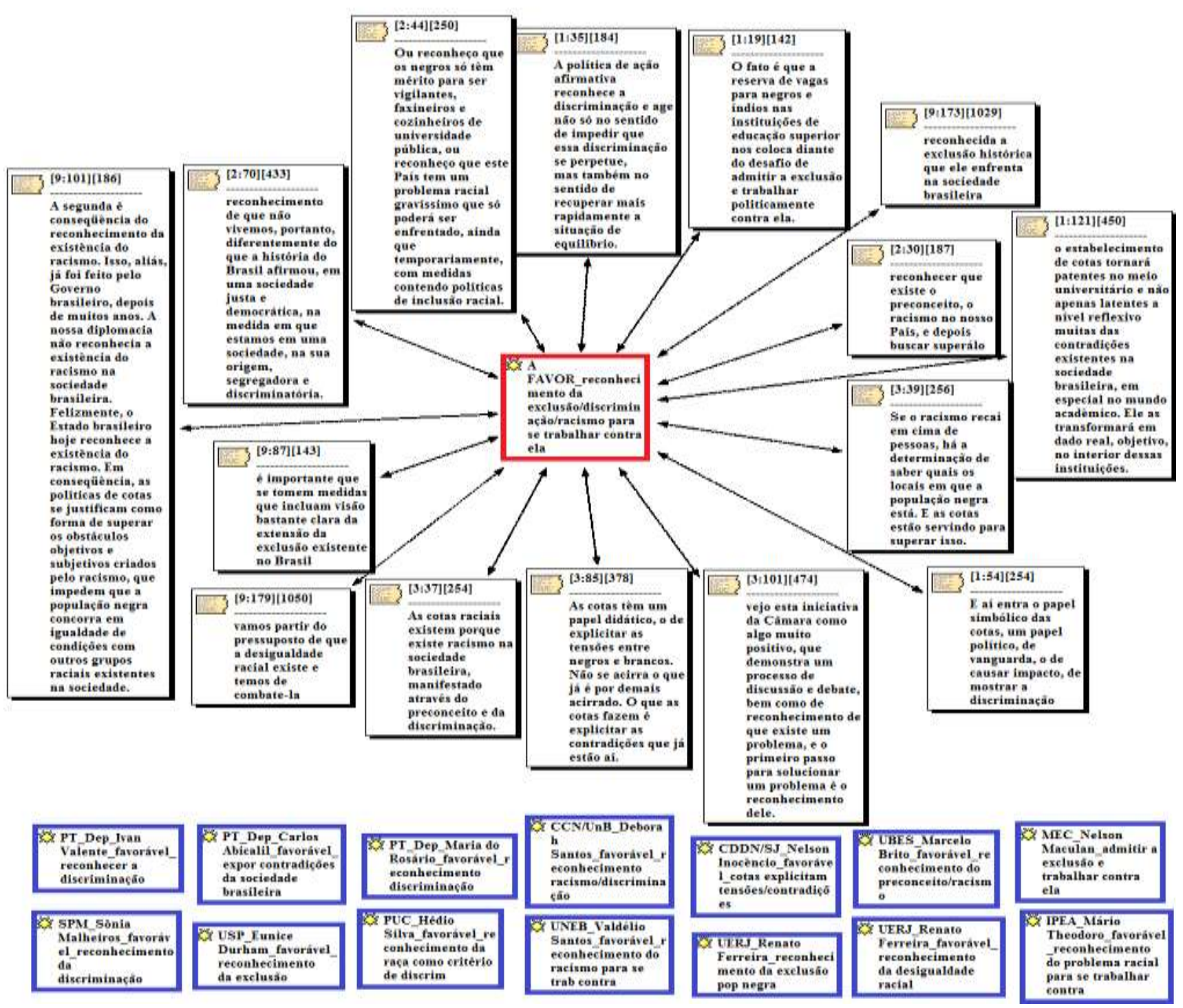


Consideramos relevante, também, destacar alguns pontos comuns nas audiências públicas e as questões que elas colocam em debate. O primeiro deles é sobre a intensa e constante participação do Poder Executivo, que esteve representado em todos os eventos. Conforme comentado anteriormente, principalmente no caso da primeira audiência pública, o que ocorreu foi um diálogo público entre os poderes, mais do que uma escuta das organizações sociais. Esse diálogo se deu de modo às vezes tenso, porém, na maioria das vezes, em tom conciliatório, e parece uma vantagem que esse diálogo público ocorra de modo que a sociedade civil pudesse acompanhar e entender as propostas.

Chama a atenção também a participação intensa de movimentos sociais, como mostra a primeira tabela deste capítulo. Alguns participaram das mesas de discussões, e outros tantos fizeram-se presentes na plateia acompanhando e manifestando-se durante os eventos. As principais vertentes de movimentos sociais presentes foram o movimento negro e o movimento estudantil e, apesar de momentos de divergência, em geral nota-se a soma de forças na defesa do projeto em trâmite. A participação constante, muitas vezes intensa e conturbada dos parlamentares também se apresenta como um ponto importante. Nota-se grande interesse e mobilização dos parlamentares em relação à matéria. Sendo o Senado Federal palco dos embates mais acalorados que ocorreram sobre o assunto nas audiências públicas.

Alguns participantes destacaram o fato de que as propostas de ações afirmativas não foram apresentadas como uma iniciativa exclusiva de um partido ou de uma vertente políticoideológica. Parlamentares de praticamente todos os partidos com representação significativa no Congresso Nacional apresentaram propostas sobre ações afirmativas. Sendo, então, difícil classificar a Lei de Cotas como uma política assistencialista do partido que estava no poder a época.

O formato das audiências públicas, com as mesas compostas por convidados préestabelecidos, sem abertura para participação da plateia, algumas vezes com o tempo restrito, parece ter efeito em como se deu a participação social nesse espaço. É certo que vozes subalternas estiveram presentes e se fizeram ouvir nesse processo, porém também são evidentes alguns limites institucionais que o próprio formato dos eventos impõe. No entanto, um aspecto que aumentou o alcance das audiências públicas foi a presença e atuação da mídia. Apesar de não ser objeto desse trabalho, a partir das falas registradas nas notas 
taquigráficas nota-se que o trabalho da mídia possuía muito eco nas intervenções feitas, tanto por parlamentares como por convidados.

A referência a modelos de ações afirmativas já existentes também se fez muito presente em todas as audiências públicas. Apesar de o modelo da Lei de Cotas não possuir antecedente legal exatamente similar, nota-se que a referência às experiências da Universidade de Brasília, da Universidade Estadual do Rio de Janeiro, entre outras, e também do Prouni estiveram constantemente permeando o debate. Ademais, se é possível fazer uma linha histórica da realização das audiências públicas, poderíamos dizer que as primeiras, que ocorreram em 2004, têm como característica a apresentação de informações iniciais sobre as propostas em trâmite; a audiência pública de 2006, por outro lado, já é marcada pelo início da polarização e da apresentação dos argumentos favoráveis e contrários; a partir de 2008, os embates políticos e as disputas passam a ser colocadas de modo contundente até a aprovação da proposta.

Por fim, como elementos gerais possíveis de serem pensados a partir de todas as audiências públicas novamente apresentamos para discussão a questão do mito da democracia racial e do racismo institucional. Alguns argumentos contrários às cotas, como a criação de ódio racial, a legislação racializada e a iniciação de conflitos raciais, podem ser compreendidos como reflexos e desdobramentos da crença de que o Brasil vive uma democracia racial. Afirmar que uma legislação como é a Lei de Cotas daria início a conflitos raciais no país bem como incitaria o ódio racial, significa acreditar que nos últimos séculos o Brasil tem sido um verdadeiro paraíso em termos de relações raciais, o que não se comprova em nenhum sentido.

Na mesma medida, não é possível compreender, senão pelas lentes do mito da democracia racial, as afirmações de que a Lei de Cotas seria a primeira lei racializada do Brasil. Estudos têm demonstrado como o Estado brasileiro tem sido negligente com a inclusão social da população negra. Após a abolição da escravatura, o que se nota é o esforço estatal em colocar obstáculos para que a população negra desfrute da cidadania plena, por exemplo afastando as pessoas negras do sistema de ensino. Apenas a crença de que o país vive uma democracia racial pode impedir que se veja essa realidade e que se acredite nesse argumento da existência de leis arraciais ou desracializadas no país. A sessão conclusiva deste trabalho apresentará mais informações sobre esse tópico. 
Consideramos relevante, também, tratar de algumas características específicas de cada casa legislativa. No caso da Câmara dos Deputados, nota-se que a maior parte das audiências públicas contaram com participações majoritariamente favoráveis. Observa-se também que a medida que as audiências públicas foram acontecendo, o debate foi amadurecendo e tornando-se mais tenso.

Na primeira audiência pública da Câmara, as exposições foram bastante conciliatórias, tratando a proposta por uma perspectiva muito positiva. Na segunda audiência pública são apresentados novos e mais enfáticos argumentos favoráveis, e algumas contraposições aos contrários começam a aparecer. Na terceira audiência pública a polarização começa a apresentar-se, sendo o embate entre Hédio Silva Jr. e Demétrio Magnoli (DEM/GO) a perfeita noção disso. A última audiência nessa casa ocorre quando já estava no STF a ação de descumprimento de preceito fundamental 186, contra as cotas implementadas na Universidade de Brasília, então, as participações tratavam deste embate.

Sobre o Senado Federal, vale destacar a igual proporção de expositores favoráveis e contrários em todas as audiências públicas. Nessa casa, conforme observado também na tramitação legislativa, apresentaram-se novas propostas com os votos em separado dos senadores. A bancada contrária a matéria trabalhou intensamente para dificultar a sua tramitação e, pelo menos, suprimir o critério racial da matéria, e as notas taquigráficas demonstram algumas das estratégias legislativas utilizadas nesse sentido.

Outra característica das audiências públicas do Senado foi a presença de organizações sociais ligadas à temática racial que se posicionaram contra as cotas raciais. Conforme anteriormente exposto no capítulo, os representantes dessas organizações colocavam-se contra as categorias raciais utilizadas pelas políticas públicas, alguns afirmando a predominância da questão de classe e também haviam aqueles que se opunham à existência da SEPPIR/PR e a tramitação do Estatuto da Igualdade Racial. Sendo, portanto, o posicionamento dessas organizações passível de reflexões mais abrangentes do que comporta este trabalho.

Desse modo, análises das audiências públicas trazem subsídios para responder à questão central deste trabalho: como se formou a Lei de Cotas? Bem como dão amparo a outras reflexões propostas ao longo desse trabalho, principalmente àquelas centradas no conceito de racismo institucional. A próxima sessão que encerrará este trabalho, além de fazer uma retomada dos acontecimentos ao longo desse processo de formação da Lei, também aprofundará a reflexão sobre racismo institucional no Brasil. 


\section{CONSIDERAÇÕES FINAIS}

Após análise documental da tramitação legislativa e análise das notas taquigráficas das Audiências Públicas é possível responder desde a perspectiva do processo legislativo, como se deu a formação da Lei de Cotas (Lei $n^{\circ}$ 12.711/2012). Esta última sessão do trabalho pretende trazer justamente um compilado dos dados mais interessantes encontrados no decorrer da pesquisa, bem como iniciar algumas discussões que me parecem relevantes, visando contribuir com as reflexões das atuais políticas públicas, com critério racial, no Brasil.

Sendo assim, essa sessão inicia-se com a apresentação dos principais dados e achados de pesquisa e, também, algumas interpretações e análises possíveis a partir da realidade observada. Logo em seguida, apresentaremos uma incipiente reflexão teórica-analítica sobre o conceito de racismo institucional e a proposta de Patrícia Hill Collins (2000) de matriz de dominação.

A proposta dessa sessão é discutir criticamente o que existe atualmente, bem como colaborar com pensamentos sobre caminhos políticos possíveis. Então, na terceira e última parte serão apresentados apontamentos iniciais sobre os desafios que se colocam na implementação da política e algumas possibilidades inexploradas de pesquisa que podem ser desenvolvidas.

\section{O PROCESSO DE FORMAÇÃO DA LEI DE COTAS}

Este trabalho argumenta que a formulação da Lei de Cotas coloca as discussões sobre ações afirmativas no Brasil em um novo momento. Assim como já mencionado, se nas décadas de 80 e 90 essas propostas começaram a ser debatidas e estudadas; no início dos anos 2000 iniciaram-se as experiências de implementação e a partir de 2012 há a consolidação de uma norma federal que padroniza o modelo de cotas que existe nas Instituições Federais de Ensino Superior e Técnico no Brasil e, em certa medida, serve de referência para as normativas estaduais e municipais. Essa nova realidade impõe novas reflexões sobre as escolhas políticas adotadas no país. 
A Lei de Cotas se insere em um contexto bem mais abrangente de políticas tanto educacionais, como relacionadas à temática racial. No âmbito das leis da área educacional, sabe-se que há correlação entre a proposta da Lei de Cotas e de políticas como o REUNI, o PROUNI, e dos novos mecanismos de seleção, como o ENEM e o SISU. Além disso, a Lei em questão está diretamente ligada às frequentes mobilizações e discussões sobre a reforma do ensino superior no Brasil.

Em se tratando de políticas de promoção de igualdade racial sabe-se que a discussão sobre ações afirmativas foi um dos temas que sustentaram a criação da SEPPIR; as discussões sobre o Estatuto da Igualdade Racial aconteceram no mesmo período em que se deram as discussões sobre a Lei de Cotas; a pressão constante e demanda insistente do movimento negro brasileiro também são fatores essenciais nesse processo; e por fim, a existência de centenas de programas de ações afirmativas difundidos por todo país também pressionavam e constrangiam o âmbito federal a posicionar-se sobre a questão.

Nesse contexto se deu o trâmite legislativo do projeto de lei inicialmente apresentado pela, então, deputada Nice Lobão que pertencia ao partido PFL - Partido da Frente Liberal (atual Democratas). Contraditoriamente esse é o mesmo partido que deu entrada na ADPF 186, contra as cotas implementadas na Universidade de Brasília. Quando foi apresentado por essa deputada o projeto não teve força política suficiente para tramitar na Câmara dos Deputados. Foi a partir de 2004, com a apresentação de um projeto de lei oriundo do Executivo Federal que a proposta de reserva de vagas para ingresso nas instituições federais de ensino ganhou força e passou a tramitar devidamente.

A centralidade do Poder Executivo na tramitação e na aprovação dessa matéria é inegável. Como já tem sido discutido por cientistas políticos brasileiros (MORAES, 2001; FIGUEIREDO e LIMONGI, 1999), o Poder Executivo possui enorme capacidade de influenciar e até mesmo direcionar as decisões do poder legislativo. No caso da Lei de cotas parece haver uma confirmação dessa tendência. Foi o projeto de lei de autoria do Executivo que tramitou com maior celeridade no Congresso Nacional, também foram parlamentares do partido dos trabalhadores que assumiram todas as relatorias da matéria nas Comissões, e outro destaque importante foi que órgãos do Executivo estiveram presente em todas as audiências públicas.

É certo que não se pode atribuir a nenhum partido político a exclusividade na proposição e na defesa das ações afirmativas, pois quase todos os partidos políticos com 
representação no Congresso Nacional apresentaram projetos de lei sobre o tema. Em se tratando de ações afirmativas para negros, ou mais especificamente cotas raciais, seria absolutamente equivocado crer que algum partido político tratou a questão de modo central. No entanto, faz-se necessário reconhecer que, estando no poder, o Partido dos Trabalhadores (PT) teve papel importante na aprovação da atual Lei de Cotas, sendo um ator político estratégico nesse processo de tramitação.

Entre 2004 e 2009 ocorreram quatro audiências públicas na Câmara dos Deputados sobre o assunto e esse foi um período de constante ampliação, polarização e acirramento do debate. É notório como entre a primeira e a última audiência públicas da Câmara dos Deputados aconteceu a agregação de argumentos favoráveis e contrários e, também, é nesse período que os personagens, os atores políticos, começam a se colocar e a aparecer defendendo seus pontos de vista. Observa-se que os deputados passaram a interessar-se cada vez mais pela matéria. Assim como nota-se a ampliação dos conhecimentos que existiam e que eram produzidos nas casas legislativas sobre o assunto.

Como já exposto no trabalho, foi na Câmara dos Deputados que o projeto adquiriu exatamente o formato que possui hoje, com os três critérios de seleção. A proposta do Poder Executivo era de que as cotas raciais estivessem condicionadas ao estudante ser oriundo de escola pública. Foram as discussões e apresentações de emendas no plenário da Câmara que inseriram para além desses dois critérios a questão de renda familiar. As propostas que chegam ao plenário geralmente estão envolvidas em uma série de discussões e mobilizações, e também, há muita ansiedade e pressão pela sua aprovação ou rejeição. Foi em um ambiente como esse que o critério de renda familiar foi incluído e que a Lei de cotas colocou em um patamar ainda menor o critério racial.

O critério racial da Lei de Cotas, assim como bem explicou Sales Santos (2015), encontra-se subsumido à questão de classe social. É mínimo e marginal. Seguramente não teria sido incluído, ou teria sido retirado do projeto de lei, se não fosse a presença e pressão constante do movimento negro e de organizações de cursos pré-vestibulares comunitários, como a EDUCAFRO.

Em 2008, quando o projeto de lei chegou ao Senado Federal diversas ações protelatórias à tramitação legislativa foram colocadas em prática. Além das sucessivas audiências públicas, foram apresentados pedidos de vista e votos em separado. Também existiu muita dificuldade para se colocar o projeto na pauta de votação na Comissão de 
Constituição e Justiça e no plenário daquela Casa. Foi marca importante das audiências públicas do Senado Federal a paridade das discussões, ou seja, a quantidade de palestrantes contrários ao projeto de lei foi exatamente igual à quantidade de palestrantes favoráveis.

Essa característica das audiências públicas do Senado Federal ofereceu a esse trabalho a oportunidade de conhecer mais a fundo as linhas argumentativas que permeavam esse debate. Entre os argumentos favoráveis que justificam as cotas raciais destaco três, que considero centrais na discussão que se segue sobre racismo institucional: 1) os prejuízos históricos acumulados pela população negra brasileira; 2) a possibilidade de se garantir acesso igualitário à direitos; e 3) o reconhecimento do critério racial como real na distribuição de oportunidades e direitos.

Da mesma forma destaco três argumentos contrários à existência de cotas raciais, igualmente interessantes para reflexões sobre o racismo institucional brasileiro: 1) a defesa de que medidas universalistas teriam o mesmo efeito que as cotas racias; 2) a divisão do país em raças ou racialização da distribuição de direitos; e 3) a marginalização de uma outra parte da população, os brancos pobres.

Se na Comissão de Constituição e Justiça do Senado Federal a matéria teve dificuldade em tramitar, nas Comissões seguintes por estratégia política o andamento foi mais célere, com menos tempo para debates e adiamento de votações. No plenário do Senado a proposição voltou a enfrentar dificuldades, mas conseguiu aprovação sem nenhuma modificação de mérito, o que garantiu a sua ida direto para sanção da Presidenta da República. Em 2012, meses após a decisão do STF pela constitucionalidade das cotas tal como implementadas pela UnB, o Senado aprova o projeto de lei que deu origem a atual Lei de Cotas (Lei n ${ }^{\circ}$ 12.711/2012).

O ano de 2012 foi, portanto, um importante ano em relação à temática de ações afirmativas no Brasil. Uma vez que aconteceu o importante julgamento da ADPF 186 pelo STF, que decidiu por unanimidade pela constitucionalidade das cotas implementadas na Universidade de Brasília; após treze anos de tramitação a Lei de Cotas foi aprovada no Congresso Nacional; e, também, foi o ano da regulamentação da Lei por parte do Ministério da Educação para efetiva implementação.

Desde 2013 estamos vivenciando no país a implementação da Lei. É verdade que esta normativa tal como formulada e regulamentada está aquém das possibilidades políticas que 
existiam, e das expectativas que possuíam os movimentos sociais e, até mesmo, as instituições de ensino. Contudo, também é necessário admitir que ante as propostas alternativas colocadas no decorrer da tramitação, esse foi o modelo de norma possível.

A Lei de Cotas (Lei n ${ }^{\circ}$ 12.711/2012) é um complexo arranjo institucional que buscou articular e conciliar de algum modo forças sociais conflitantes que estavam em disputa. Foram inúmeros atores políticos que influenciaram todo esse trâmite legislativo, alguns deles nominados ao longo desta dissertação, mas seguramente outros tantos não foram identificados por essa pesquisa. Na tentativa de sistematizar quais áreas ou quais grupos participaram desse processo podemos citar:

- A mídia, que sempre esteve presente cobrindo jornalisticamente a tramitação e os eventos. Direta ou indiretamente influenciou vários posicionamentos com a apresentação de editoriais, matérias e entrevistas sobre o tema;

- A comunidade acadêmica, tanto estudantes como professores e reitores fizeram-se presentes no debate, geralmente, apresentando os resultados das ações afirmativas em suas instituições de origem, ou oferecendo subsídios para a formulação da lei, ou expondo suas ideias e concepções de Brasil;

- Os movimentos sociais, em especial o movimento negro, um protagonista das discussões e embates. Diversos grupos se fizeram representar tanto nas audiências públicas como nos pareceres dos relatores, o movimento estudantil também se apresentou como importante interlocutor para este projeto de lei;

- As próprias instituições públicas, como o Ministério da Educação, a Secretaria de Promoção da Igualdade Racial, o Instituto de Pesquisas Econômicas Aplicadas, o Instituto Brasileiro de Geografia e Estatística, entre outras, estiveram presentes apresentando seus posicionamentos, justificativas e subsídios para o assunto;

- Os tomadores de decisão (parlamentares) e os partidos políticos, além de se utilizarem das informações agregadas por todos os atores anteriormente citados, criam seus próprios modos de interpretação da realidade, e suas formas particulares de formulação de políticas sendo esses, portanto, importantíssimos atores do processo de formação da lei.

Em nenhum desses cinco grupos de atores políticos havia homogeneidade de opinião em relação ao tema. As disputas, os conflitos, as divergências e as contradições se mostram em cada um dos grupos ao longo desses anos de discussão do tema. Isso demonstra a dimensão dos interesses que esse projeto de lei atingia. Foram muitos atores envolvidos e muitos esforços dedicados nesses anos de tramitação. Dividir os espaços de privilégio e poder 
das instituições de ensino mais relevantes do país foi, e continua sendo, algo alcançado por meio de muito enfrentamento e luta por reconhecimento e redistribuição.

Nota-se que inclusive nos espaços em que se esperava maior participação social popular - as audiências públicas - existiram limitações e obstáculos. As audiências públicas foram sim locais de ricas trocas de informações, grandes embates políticos, de oferecimento de diversos subsídios aos parlamentares. Contudo, o formato desses eventos em que não há participação da plateia, por exemplo, impedem que a discussão se dê de modo ainda mais amplo e democrático.

Este trabalho, assim como outros que discutem relações raciais no Brasil, coloca em pauta a branquitude ${ }^{58}$. Os interesses, as lógicas de manutenção do poder, os refinados mecanismos de exclusão e silenciamento precisam ser profundamente estudados pela literatura brasileira. O trabalho aqui apresentado demonstra detalhadamente como se deu a marginalização da temática racial na tramitação da Lei de Cotas. Acredita-se que qualquer discussão sócio-política no Brasil deve considerar como um elemento central as relações raciais. O racismo, esse camaleão poliglota, tem se reinventado nos discursos e práticas da branquitude brasileira, que continua entendendo as relações raciais no Brasil pelas lentes do mito da democracia racial.

Ao se tratar de branquitude estamos aqui envolvendo todos os espectros políticoideológicos, que mesmo em sociedades que viveram a escravidão e o colonialismo, não conseguem enxergar a centralidade da temática racial. Uma das contradições que se destacam na tramitação dessa lei é argumentação de vários parlamentares petistas, que disseram ser mais racional a formulação de uma lei em que o critério racial estivesse subsumido ao critério de classe. Esse fato aponta para a tensa relação existente entre a esquerda política e a questão racial.

O não comprometimento com a centralidade da discussão racial e a preferência predominante da questão de classe em detrimento da questão de raça evidencia como o racismo institucional perpassa distintas vertentes ideológicas. Ele é notado tanto na direita conservadora, como na esquerda progressista. Como brilhantemente disse Sueli Carneiro: "Entre a esquerda e a direita, eu continuo preta!"

\footnotetext{
${ }^{58}$ Seguindo as ideias de Thula Pires (2013): “branquitude é uma categoria de análise que permite pensar como as relações socioeconômicas, socioculturais e psíquicas determinam quem é e não é o branco e, consequentemente, quem está apto a beneficiar-se do sistema de privilégios de uma sociedade racista". (p. 41)
} 
Esta pesquisa demonstra que mesmo os parlamentares tendo acesso e utilizando indicadores e dados sobre desigualdades raciais, mesmo eles reconhecendo discursivamente os prejuízos socioeconômicos vivenciados pelos negros em decorrência da escravidão, mesmo após a decisão do STF sobre a constitucionalidade das cotas raciais; não houve sensibilidade suficiente desses parlamentares para compreender a importância e centralidade das cotas raciais. O que é indício de que a ocupação majoritariamente branca dos cargos eletivos, ou de funções no poder, têm impacto em decisões que dizem respeito à população negra brasileira. A baixa representação e a baixa representatividade negra no Congresso Nacional também é uma das facetas do racismo institucional.

Este trabalho apresenta uma série de possibilidades de reflexão tanto sobre a Lei de Cotas como temos hoje, como sobre a sociedade brasileira e sua organização política e social. Racismo institucional parece ser um conceito capaz de explicar parte significativa das relações de poder tais como vistas na tramitação desse projeto. Não será possível desenvolver aqui, mas vale apontar que a estrutura e o funcionamento do sistema político-eleitoral brasileiro afastam, ou não possibilitam, o ingresso significativo de negros em espaços de tomada de decisão.

A seguir iniciarei uma reflexão ainda embrionária sobre conceitos teóricos e analíticos que parecem contribuir para o fechamento desse trabalho. Serão discutidos os conceitos: racismo institucional e matriz de dominação.

\section{RACISMO INSTITUCIONAL E MATRIZ DE DOMINAÇÃO: BREVE REFLEXÃO SOBRE O PROCESSO DE FORMAÇÃO DA LEI A PARTIR DESSAS LENTES}

A discussão sobre racismo institucional esteve presente em todos os capítulos deste trabalho, desde o início me pareceu um conceito essencial ao se investigar a formação de uma legislação. Como se sabe as leis são instituições, e as relações sociais são diretamente influenciadas por elas, bem como influenciam sua construção. Desse modo, tratar de racismo de forma estrutural parece ser um caminho adequado.

O surgimento do conceito se deu com a luta norte-americana pelos direitos civis na década de 1960, desde então reflexões a respeito desse tema têm sido feitas pelo mundo todo. No caso brasileiro, nota-se que essa é uma discussão recente e, de certo modo, incipiente e há alguns trabalhos produzidos sobre o assunto. Três materiais serão especialmente incorporados 
aqui, o livro de Ivair dos Santos (2013) Direitos humanos e práticas de racismo; o livro Racismo Institucional: uma abordagem conceitual, organizado pelo Instituto Géledes (2013), com redação de Jurema Werneck; e o livro No país do racismo institucional (2013), produzido pelo Ministério Público do estado de Pernambuco.

Para iniciar é importante definir com maior precisão o que estamos chamando de racismo institucional e para isso lançamos mão do que há disponível na literatura brasileira. De acordo com Thula Pires (2013):

\begin{abstract}
"O racismo institucional aparece como um sistema generalizado de discriminações inscritas nos mecanismos rotineiros, assegurando a dominação e a inferiorização dos negros sem que haja necessidade de teorizá-la ou justificá-la pela ciência. Conforme interpretação de Wieviorka (2007) esse conceito promove uma representação social que transcreve os relacionamentos sociais em termos raciais, insistindo nas práticas que asseguram sua reprodução e dominação, dissociando ator e sistema. Ao mesmo tempo em que indica que o declínio das doutrinas científicas de raça não implica a do próprio racismo, exonera os grupos que se beneficiam dessa hierarquia racial de toda suspeita de racismo, na medida em que a prática aconteceria no âmbito das instituições." (PIRES, 2013, p.51)
\end{abstract}

Sendo assim o conceito refere-se ao entendimento de que as instituições podem agir de modo racialmente excludente. Acredita-se que para além daquele racismo que ocorre entre indivíduos, existem outras dimensões do racismo que independem da vontade dos sujeitos. De maneira bastante didática o livro Racismo Institucional: uma abordagem conceitual (2013) apresenta a seguinte figura, que sistematiza a proposta conceitual.

Figura 13 - Diagrama explicativo de racismo institucional

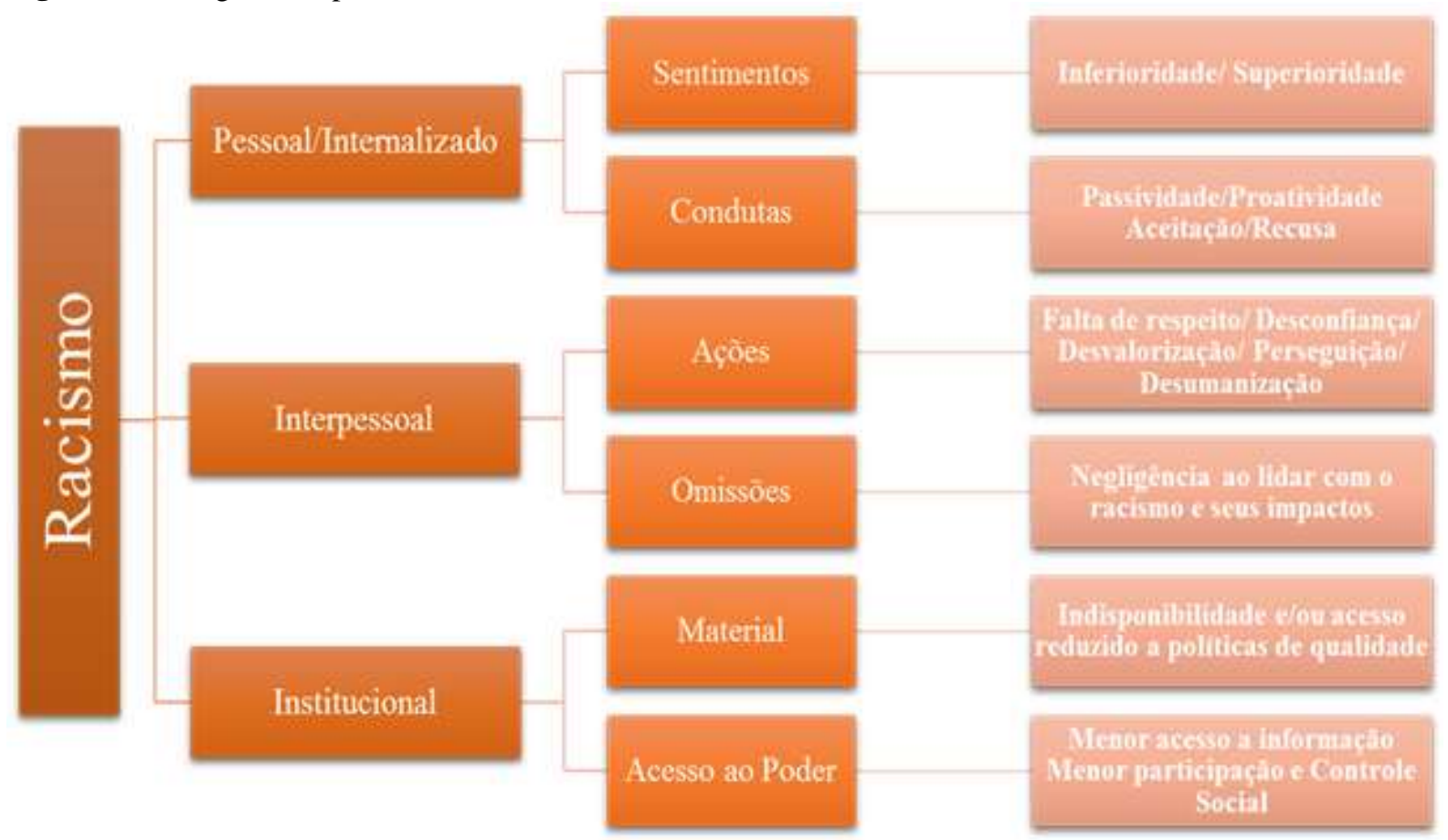

Fonte: Livro Racismo Institucional: uma abordagem conceitual (2013), adaptação a partir da conceituação proposta por Câmara P. Jones. 
Para além de estar presente nas relações entre as pessoas e grupos, nota-se que o racismo se mostra no desenho das políticas públicas e também nas estruturas de governo e modos de organização do Estado. Nesse sentido, Jurema Werneck (2013) apresenta a seguinte definição:

(...) o racismo institucional, também denominado racismo sistêmico, como mecanismo estrutural que garante a exclusão seletiva dos grupos racialmente subordinados - negr@s, indígen@s, cigan@s, para citar a realidade latinoamericana e brasileira da diáspora africana - atuando como alavanca importante da exclusão diferenciada de diferentes sujeit@s nestes grupos. Trata-se da forma estratégica como o racismo garante a apropriação dos resultados positivos da produção de riqueza pelos segmentos raciais privilegiados na sociedade, ao mesmo tempo em que ajuda a manter a fragmentação da distribuição destes resultados no seu interior. (WERNECK, 2013, p.16)

Sendo assim, uma das vantagens do conceito conforme aponta Santos (2013) é a denúncia da discriminação racial dissimulada. Ou seja, essa compreensão de racismo possibilita analisar uma sociedade em que os grupos dominantes não tenham consciência de seu racismo ou até mesmo possam ter um discurso antirracista. No entanto a realidade demonstra uma resistência a qualquer mudança nas condições sociais dos grupos subalternos, que buscam, então, a manutenção do status quo. Conforme expõe Werneck (2013), em referência a Gary King (1996): "Pessoas e organizações que se beneficiam do racismo institucional são refratárias a mudanças voluntárias do status quo".

Para além de caracterizar-se como práticas institucionais inadequadas, o racismo institucional pode ser compreendido como um mecanismo performativo, que produz e reproduz condutas excludentes legitimando as ações governamentais. Nesse sentido, as práticas de racismo institucional mais do que um 'fracasso institucional', conforme afirma Sales Jr. (2011), demonstram-se nas contradições presentes entre o discurso formal/oficial e as práticas cotidianas das instituições, sejam elas formais ou informais. No mesmo sentido argumenta Ivair Santos (2012):

\footnotetext{
O racismo institucional é revelado através de mecanismos e estratégias presentes nas instituições públicas, explícitas ou não, que dificultam a presença de negros nesses espaços. O acesso é dificultado, não por normas e regras escritas e visíveis, mas por obstáculos formais presentes nas relações sociais que se reproduzem nos espaços institucionais e públicos. A ação é sempre violenta, na medida em que atinge a dignidade humana. (SANTOS, 2013, p.27)
}

Entender e admitir a existência de racismo institucional na sociedade brasileira é o primeiro passo para realização das modificações sociais necessárias. O histórico de relações raciais no Brasil possui uma especificidade que, em minha opinião, agrava bastante o não reconhecimento do racismo institucional que é o mito da democracia racial. A crença de que 
vivemos em um país com relações raciais harmoniosas, em que brancos e nãobrancos convivem de modo legalmente igualitário obscurece a capacidade de compreender a complexidade do racismo no Brasil. Conforme discutido no livro No país do racismo institucional (2013) a democracia racial é:

(...) uma espécie de ciclo que vai, há séculos, se retroalimentando: se não somos exatamente negros, se vivemos em um local de paz racial, não há porque tomar qualquer medida em relação a um hipotético ruído referente a discriminação baseada na cor da pele. (MORAES, 2013, p.20)

No entanto, como vem sendo denunciado há décadas pelo movimento negro esse entendimento das relações raciais no Brasil não se sustenta, basta observar qualquer indicador socioeconômico do país. Desigualdades históricas e sistêmicas têm se acumulado sobre a população negra brasileira, não apenas como resquício da escravidão, mas também como consequência da atuação estatal no sentido do branqueamento populacional e no oferecimento de condições desiguais de bem-estar social para brancos e não-brancos.

Sendo assim, ouso afirmar que a perpetuação e reificação do mito da democracia racial é um dos pilares do racismo institucional brasileiro. Este mito foi e tem sido utilizado por diversas instâncias governamentais e usufrui de enorme difusão nos discursos sociais do país, de modo que é usado como uma justificativa para inação estatal, aprofundando a exclusão racial. A existência dessas crenças permite inclusive questionar-se sobre a democracia brasileira e seus limites, assim como faz Jurema Werneck (2013):

(...) o racismo como fenômeno produtivo guarda profundas relações com a constituição da modernidade capitalista ocidental, bem como seus processos econômicos e sociais. E ele se confunde em variadas formas, com a democracia institucionalizada em nossa região. Não será coincidência, portanto, sua invisibilização diante de quadros tão exuberantes de hegemonia branca. (WERNECK, 2013, p.33)

Desse modo é possível compreender que o monopólio político e econômico dos grupos racialmente dominantes contribui para a produção de discursos e perspectivas que legitimam o privilégio. A partir das ideias de Werneck (2013) nota-se que os caminhos, as alternativas e as lógicas utilizadas vinculam-se com a continuidade das relações de poder, dominação e subordinação, e ao mesmo tempo criam condições para a sua reprodução.

Em sintonia com a proposta conceitual de racismo institucional parece-me extremamente relevante e atual o modelo analítico de relações de poder desenvolvido por Patrícia Hill Collins (2000). Como uma das autoras do pensamento feminista negro norte americano, ela argumenta que na busca pelo empoderamento é importante se conhecer a fonte 
e o modus operandi do poder, bem como defende uma visão de análise interseccional das opressões.

A autora argumenta que, no caso norte americano, existe tradição de um pensamento político e social crítico das mulheres negras, porém essas ideias são invisibilizadas ou suprimidas. E é nesse sentido que o pensamento feminista negro demonstra sua relevância histórica, uma vez que para além da produção de conhecimento, há o compromisso com a busca por justiça social e superação de estereótipos coloniais. É uma proposta de empoderamento dos sujeitos políticos subalternizados.

Hill Collins argumenta que a partir da perspectiva desses sujeitos - especialmente mulheres negras - é possível ter novos olhares sobre temas específicos, sobretudo em relação ao racismo institucional. De acordo com ela, deve-se desenvolver uma luta autônoma, mas não separatista. No último capítulo de seu livro Black Feminist Thought, a autora apresenta uma reflexão que articula ativismo e dominação. De modo estruturado expõem um modelo em que sistematiza as formas de dominação, que se divide em domínio estrutural, disciplinar, hegemônico e interpessoal. De acordo com Silva (2016):

\begin{abstract}
"Segundo essa matriz de dominação há poucas vítimas ou opressores puros no contexto em que variadas perspectivas afetam diferentemente as pessoas em uma sociedade (classe, raça, gênero, origem, sexualidade). Com a conjunção dos eixos de dominação (raça, gênero, sexualidade, origem, classe) e os domínios de poder (estrutural, interpessoal, disciplinar e hegemônico) é possível analisar de forma mais complexa a realidade do que apenas focar na lógica opressor e oprimido."
\end{abstract}

(SILVA, 2016, p.10)

Em síntese, seu modelo teórico argumenta que no domínio estrutural as instituições reproduzem de modo sistemático padrões de desigualdade. O modo de organização institucional propicia a reprodução do racismo, ampliando desigualdades especialmente no caso das mulheres negras. No domínio disciplinar a autora trata da atuação da burocracia, tanto no gerenciamento das relações de poder dentro das organizações, como no impedimento da execução de políticas voltadas para a promoção da igualdade. No domínio hegemônico a autora aborda a consciência, a cultura e a ideologia como legitimadoras de práticas de dominação históricas, sendo essas práticas propagadas por escolas e universidades, religiões e famílias, por exemplo. No domínio interpessoal estariam concentradas as ações cotidianas de interação social, sendo esse o espaço onde vigoram as estratégias individuais de resistência. (SILVA, 2016) 
As definições e reflexões da autora são bem mais sofisticadas do que este trabalho será capaz de expor, ainda assim parece bastante relevante a breve apresentação dessa teoria que amplia as possibilidades de compreensão das relações de poder bem como oferece soluções alternativas para pensarmos em uma realidade socialmente mais justa. Conforme expõe Tatiana Silva (2016) ao abordar o domínio hegemônico:

"[este é o domínio que] busca justificar os domínios estrutural e disciplinar.
Funciona como uma conexão entre as instituições (domínio estrutural), práticas
organizacionais (domínio disciplinar) e interação social (domínio interpessoal). Para
seu enfrentamento é necessário se contrapor a essas ideologias, mas também
oferecer alternativas. Neste domínio o empoderamento significa tanto a liberdade
para pensar livremente, como criar livremente outras racionalidades." (SILVA,
2016, p.11)

Sendo assim, nessa proposta Hill Collins nos oferece a possibilidade de analisar as relações sociais a partir de uma matriz de dominação e, também, apresenta formas de empoderamento para lidar com esses tipos de dominação. O Pensamento Feminista Negro compreende o poder como algo relacional, ou seja, algo que está dentro das relações, por isso há margem para a ação e intervenção humana. Esta é uma proposta que busca desestabilizar e reconstruir relações estruturalmente desiguais, como por exemplo as de gênero, raça e classe. Há aí uma busca por superar as formas hegemônicas de se pensar as relações, é uma proposta de política de realização do aqui e agora com o mundo que lidamos e, também, propõe uma transfiguração, ultrapassando o linguístico possível e criando um novo mundo. (QUEIROZ, 2016)

As ideias de Hill Collins, bem como as conceituações de racismo institucional, parecem muito inspiradoras para se pensar não apenas as políticas públicas que temos no Brasil, mas também as políticas que queremos. Um trabalho como o apresentado nesta dissertação alinha-se a diversos outros que expõem o racismo à brasileira, os modos de argumentação dos tomadores de decisão política, as releituras do mito da democracia racial e a magnitude das forças hegemônicas que se organizam contra as propostas políticas para a população negra.

Como sabe-se o apagamento, silenciamento e supressão das ideias sócio-políticas das pessoas negras tende a ocorrer nos processos decisórios, como foi no caso da Lei de Cotas. No entanto, em proporção crescente também estão surgindo vozes subalternizadas empoderadas de conhecimento, novas lógicas de pensamento e modos de atuação política para se contrapor a esses sistemas. 
Toda essa reflexão remete ao tramite da Lei de Cotas em que se observa a forte resistência à modificação dos processos seletivos das instituições de ensino federais. Como nota-se, por exemplo, nos documentos produzidos pelos parlamentares geralmente reverberam a crença de que há um povo brasileiro, unificado, e que a divisão em raças não é politicamente positiva para o Brasil. Nas audiências públicas houve depoimentos no sentido de reivindicar uma identidade étnica híbrida, mestiça, posicionando-se completamente contrários a qualquer política de igualdade racial. Há aí, por exemplo, casos de incorporação do discurso da democracia racial e ao mesmo tempo formas discursivas que auxiliam na perpetuação do racismo institucional.

É impressionante que mesmo conhecendo e admitindo haver desigualdades raciais socioeconômicas gritantes, a defesa da maioria dos parlamentares era por políticas universalistas, numa proposta de lei 'arracializada'. Como sabe-se, geralmente, iniciativas que se dizem neutras e universais, na verdade são destinadas ao atendimento da parcela branca da sociedade. E nesse sentido, com o passar do trâmite legislativo ficou evidente qual era o problema central na discussão do projeto a ausência do branco como ator central no processo. A tramitação da Lei de Cotas indica que é muito difícil para a elite política brasileira refletir, compreender, discutir e decidir sobre temática que inclua atores diversificados, temática que beneficie parcelas sociais distintas daquelas que sempre usufruem das benesses do Estado.

\section{NOVOS DESAFIOS POLÍTICOS E POSSIBILIDADES DE PESQUISA INEXPLORADAS}

Conforme exposto anteriormente, apesar das críticas e insatisfações com a legislação vigente, parece frutífero pensar em algumas questões que dizem respeito à implementação da lei, agora conhecendo detalhadamente seu processo de formulação.

Este trabalho não pretendeu se debruçar sobre as seguintes etapas do ciclo de políticas públicas: implementação, acompanhamento e avaliação. Apenas serão apresentados breves apontamentos sobre aspectos importantes a serem pensados politicamente e, também, em outras pesquisas acadêmicas.

O primeiro ponto a destacar-se é a questão da permanência dos cotistas nessas Instituições de Ensino. Sabe-se que possibilitar o acesso é parte importante, mas para se alcançar resultados efetivos é indispensável investimentos na permanência desses novos 
estudantes. Acredito que mais do que ter estudantes de baixa renda e negros nas instituições, o resultado maior que se espera é que esses estudantes concluam seus cursos e consigam boa alocação no mercado de trabalho, melhorando assim as condições socioeconômicas dele e de seus familiares.

Para tanto é necessário a criação e ampliação de mecanismos que possibilitem a permanência material e a permanência simbólica desses estudantes nesses espaços. Em se tratando de permanência material, sabe-se que é necessário que sejam garantidas pelo menos condições básicas de alimentação, transporte e aquisição dos materiais necessários para bom aproveitamento dos cursos. Já em relação à permanência simbólica, parece essencial a valorização de outras lógicas de conhecimento e existência não eurocêntricas, um dos aspectos relacionados a isso é a discussão sobre as disciplinas oferecidas nos cursos e seus conteúdos.

O segundo aspecto relacionado à implementação e acompanhamento da política pública é a questão das fraudes nas cotas. Já se sabe por meio de informações da grande mídia e, também, por denúncias em redes sociais de coletivos de estudantes negros, que a Lei de Cotas tem sido burlada em várias instituições de ensino. Estudantes, que não são o público alvo da reserva de vagas, têm emitido falsas declarações para se beneficiarem injustamente da política.

Um outro aspecto vinculado à implementação da Lei de Cotas tem a ver com o principal instrumento de acesso a vagas de instituições públicas de ensino superior, o SISU (Sistema de Seleção Unificada), de responsabilidade do MEC. Algumas notícias ${ }^{59}$ indicam que as notas de corte dos alunos cotistas são maiores do que as notas da ampla concorrência. Este fato indica que as cotas podem estar sendo utilizadas como um teto (e não como um piso) para o ingresso dos estudantes negros e de baixa renda o que, na prática, significa obstáculos maiores para o ingresso de mais estudantes beneficiários das cotas.

\footnotetext{
${ }^{59}$ O jornal Extra publicou em 10/01/2013 notícia intitulada SISU 2013: Em 1/4 dos cursos da UFRJ, notas de corte cotistas são maiores do que ampla concorrência. Disponível em: <http://extra.globo.com/noticias/educacao/vida-de-calouro/sisu-2013-em-14-dos-cursos-da-ufrj-notas-decorte-de-cotistas-sao-maiores-que-da-ampla-concorrencia-7247301.html> e site da Universidade Federal de Pernambuco que divulga que as maiores notas do SISU são de engenharia, e que a nota dos cotistas é maior do que a nota de ampla concorrência. Disponível em: <https://www.ufpe.br/agencia/clipping/index.php?option=com content\&view=article\&id=15485:maiore s-notas-dosisu-sao-de-engenharia \& catid=72\&|temid=122>
} 
Esse é um aspecto que merece e necessita enorme atenção tanto dos estudiosos no tema, como dos atores políticos com poder de fiscalização. Sabe-se que, com a Lei de Cotas, as instituições de ensino tornaram-se obrigadas a fazer seus processos seletivos com reserva de vagas, e parece-me lógico que essas mesmas instituições tenham a responsabilidade de garantir que as vagas reservadas sejam ocupadas por quem possui o direito de ocupá-las. Sendo as comissões de verificação das declarações uma importante prática nesse sentido.

O terceiro aspecto é justamente a existência ou não dessas comissões nos processos seletivos. Assim como já dito, parece-me que essa comissão é indispensável no sentido das instituições terem seu mecanismo de controle e fiscalização da lisura de suas seleções. Contudo, também acredito que é importante pensar-se no modelo de comissão e nas práticas que serão realizadas por elas.

O quarto aspecto diz respeito ao comitê nacional de acompanhamento da Lei de Cotas, que parece ser algo muito importante no sentido de monitorar o que tem sido realizado pelas instituições de ensino pelo país. Uma boa avaliação e a reformulação da política pública dependem de um bom processo de monitoramento da implementação e funcionamento dela. Pelo que se sabe o comitê foi instalado e realizou uma reunião em 2016, contudo não há informações públicas sobre suas análises e reflexões da implementação da Lei.

O quinto e último ponto de destaque refere-se à atuação do sistema de justiça em relação às cotas. Parece-me bastante interessante que sejam realizados novos estudos sobre a decisão do STF, em relação à ADPF 186, a audiência pública realizada por esse órgão contou com três dias de exposições e participação social ampla. Seria muito interessante a realização de análises e reflexões do ponto de vista sociológico e político da decisão da corte. Também, sabe-se que está ocorrendo muita divergência nas decisões de juízes por todo o país em relação à Lei de Cotas, em relação a quem pode ocupar as vagas reservadas. Esse parece ser um interessante caminho de pesquisa. 


\section{REFERÊNCIAS BIBLIOGRÁFICAS}

ANDREWS, George Reid. Democracia racial brasileira 1900-1990: um contraponto americano. Estudos Avançados [online]. v. 11, n. 30. p. 95-115, 1997.

AVRITZER, Leonardo; GOMES, Lilian C. B. Política de reconhecimento, raça e democracia no Brasil. DADOS Revista de Ciências Sociais, Rio de Janeiro, v. 56, p. 39-68, 2013.

BERNARDINO, Joaze. Ação afirmativa e a rediscussão do mito da democracia racial no Brasil. Estudos afro-asiáticos, v. 24, n. 2, p. 247-273, 2002.

BERNARDINO, Joaze. Ações afirmativas: respostas às questões mais frequentes. O Público e o Privado, n. 3, 2012.

BERNARDINO, Joaze. Levando a raça a sério: ação afirmativa e correto reconhecimento. In: BERNARDINO, Joaze; GALDINO, Daniela (Orgs.). Levando a raça a sério: ação afirmativa e universidade. Rio de Janeiro: DP\&A, 2004.

BOBBIO, Noberto. O futuro da democracia. Rio de Janeiro: Paz e Terra, 2009.

COLLINS, Patricia Hill. Black feminist thought: Knowledge, consciousness, and the politics of empowerment. New York: Routledge, 2000.

DE CARVALHO, José Jorge. Inclusão étnica e racial no Brasil: a questão das cotas no ensino superior. São Paulo: Attar Editorial, 2005.

FERES JR, João; DAFLON, Verônica Toste; CAMPOS, Luiz Augusto Campo. Ação afirmativa no ensino superior brasileiro hoje: análise institucional. GEMAA: Rio de Janeiro, 2011.

FERES Jr., João. Ação Afirmativa na Índia e no Brasil: um estudo sobre a retórica acadêmica. Sociologias. Porto Alegre, ano 17, n. 40, p. 92-123, set./dez. 2015.

FERES Jr., João. Ação afirmativa no Brasil: fundamentos e críticas. Econômica, v. 6, n. 2, p. 291-312, 2004.

FERREIRA, Renato. Ações Afirmativas a questão das cotas: análises jurídicas de um dos assuntos mais controversos da realidade. Niterói, Rio de Janeiro: Impetus, 2011.

FERREIRA, Renato. Dez anos de promoção da igualdade racial: balanços e desafios. In: SADER, Emir (Org.). 10 anos de governos pós-neoliberais no Brasil: Lula e Dilma. São Paulo: Boitempo; Rio de Janeiro: FLACSO Brasil, 2013.

FERRARI, Regina Maria Macedo Nery. Participação democrática: audiências públicas. In: GRAU, Eros Roberto; CUNHA, Sérgio Sérvulo da (Coords). Estudos de Direito Constitucional em homenagem a José Afonso da Silva. São Paulo: Malheiros Editores, 2003. 
FIGUEIREDO, Argelina Cheibub; LIMONGI, Fernando. Executivo e Legislativo na nova ordem constitucional. Rio de Janeiro: Editora FGV, 1999.

GILROY, Paul. O Atlântico negro. Editora 34, 2001.

GIDDENS, Anthony. Sociologia. 6 ed. Fundação Calouste Gulbenkian, 2001.

GOMES, Flávio; DOMINGUES, Petrônio. Políticas da raça: experiências e legados da abolição e da pós-emancipação no Brasil. São Paulo. Selo Negro Edições. 2014.

GOMES, Joaquim Benedito Barbosa. Ação afirmativa e princípio constitucional da igualdade: o direito como instrumento de transformação social: a experiência dos EUA. Renovar, 2001.

GOMES, Nilma Lino. Movimento negro e educação: ressignificando e politizando a raça. Educação e Sociedade, v. 33, n. 120, p. 727-744, jul-set, 2012.

GONÇALVES, Luiz Alberto Oliveira e SILVA, Petronilha Beatriz Gonçalves. Movimento negro e educação. Revista Brasileira de Educação, n. 15, 2000.

GONÇALVES, Maria Alice Resende; PEREIRA, Vinicius Oliveira. O contexto histórico das políticas racializadas e a emergência de novas etnicidades. A emergência do discurso racializado no sistema de ensino. Revista Telas, v.14. n. 34, p. 33-48.

GUIMARÃES, Antonio Sérgio Alfredo. Racismo e Antiracismo no Brasil. 3. ed. Editora 34. São Paulo. 2009.

HASENBALG, Carlos A.; DO VALLE SILVA, Nelson. Raça e oportunidades educacionais no Brasil. Cadernos de Pesquisa, n. 73, p. 5-12, 2013.

INEP - Instituto Nacional de Estudos e Pesquisas Educacionais Anísio Teixeira. Adriano Souza Senkevics ; Taís de Sant'Anna Machado ; Adolfo Samuel de Oliveira. A cor e a raça nas estatísticas educacionais: uma análise dos instrumentos de pesquisa do INEP. Brasília. 2016.

IPEA - Instituto de Pesquisa Econômica Aplicada. Instrumentos Normativos Federais relacionado ao preconceito e às desigualdades raciais (1950 a 2013). Diretoria de Estudos Sociais. Projeto BRA 01/013, Brasília. 2011.

JACCOUD, Luciana; BEGHIN, Nathalie. Desigualdades raciais no Brasil: um balanço da intervenção governamental. Brasília: Ipea, 2002.

JACCOUD, Luciana; BEGHIN, Nathalie et alli. Entre o racismo e a desigualdade: da Constituição à promoção de uma política de Igualdade Racial (1988-2008). Políticas Sociais: acompanhamento e análise - vinte anos de Constituição Federal. Brasília: Ipea, 2009.

DE JESUS, Rodrigo Ednilson; GOMES, Nilma Lino. A “Constituição" da nação brasileira em disputa: o debate em torno da (in) constitucionalidade das ações afirmativas. Revista TOMO, n. 24, jan.-jun. 2014. 
LEWANDOWISK, Ricardo. Voto sobre a ADPF 186. 2012.

LIMA, Marcia. Ações Afirmativas e juventude negra no Brasil. 2015. Disponível em: http://www.kas.de/wf/doc/16489-1442-5-30.pdf . Acesso em: 15 out. 2016.

MARTINS, Sergio S. Ação Afirmativa e desigualdade Racial no Brasil. Revista Estudos Feministas. p. 202-208, 1996.

DE MENEZES, Paulo Lucena. A ação afirmativa (affirmative action) no direito norteamericano. Ed. Revista dos Tribunais, 2001.

MOEHLECKE, Sabrina. Ação afirmativa: história e debates no Brasil. Cadernos de pesquisa, v. 117, n. 11, p. 197-217, 2002.

MORAES, Filomeno. Executivo e Legislativo no Brasil pós-constituinte. São Paulo em Perspectiva, v. 15, n. 4, p. 45-52, 2001.

MORAES, Fabiana. No país do racismo institucional: dez anos de ações do GT Racismo no MPPE. Recife: Procuradoria Geral de Justiça, 2013.

MUNANGA, Kabengele. Identidade, cidadania e democracia: algumas reflexões sobre os discursos anti-racistas no Brasil. Resgate-Revista Interdisciplinar de Cultura, v. 5, n. 6, p. 17-24, 1996.

MUNANGA, Kabengele. Políticas de ação afirmativa em benefício da população negra no Brasil: um ponto de vista em defesa de cotas. Sociedade e cultura, v. 4, n. 2, 2007.

MUNANGA, Kabengele. Uma abordagem conceitual das noções de raça, racismo, identidade e etnia. Programa de educação sobre o negro na sociedade brasileira. Niterói: EdUFF. 2000 .

PEREIRA, Amilcar; ALBERTI, Verena. A defesa das cotas como estratégia política do movimento negro contemporâneo. Estudos Históricos, Rio de Janeiro, n. 37, jan.-jun. 2006.

PEREZ, M. A. A Administração pública democrática: institutos de participação popular na Administração Pública. Belo Horizonte: Fórum, 2004.

PIRES, Thula. Criminalização do racismo: entre política de reconhecimento e meio de legitimação do controle social dos não reconhecidos. 2013. 283 f. Tese. (Doutorado em direito) - Departamento de Direito, Pontifícia Universidade Católica do Rio de Janeiro, Rio de Janeiro. 2013.

QUEIROZ, Marcos Vinícius. Anotações da disciplina Raça, Racismo e Antirracismo. 2016. (memo)

RAMOS, Alberto Guerreiro. Introdução crítica à sociologia brasileira. Editora UFRJ, 1995. 
RIBEIRO, Matilde. Políticas de promoção da igualdade racial no Brasil (1986-2010). Rio de Janeiro: Garamond, 2014.

RISTOFF, Dilvo. O espelho distorcido. Cadernos do GEA. jan./jun. FLACSO, GEA, UERJLPP. Rio de Janeiro, 2012. Disponível em: <http://flacso.redelivre.org.br/files/2015/03/Caderno_GEA_N1.pdf>.

ROCHA, Carmen Lúcia Antunes. Ação afirmativa: o conteúdo democrático do princípio da igualdade jurídica. Gênesis: Revista de Direito Administrativo Aplicado, v. 3, n. 10, p. 649-664, jul./set. 1996, 1996.

SANTOS, Jocélio Teles (org.). Cotas nas universidades análise dos processo de decisão. Salvador: CEAO, 2012.

SANTOS, Jocélio Teles dos. Dilemas nada atuais das políticas para os afro-brasileiros: ação afirmativa no Brasil dos anos 60. In: BACELAR, J.; CARDOSO, C. A. (orgs.). Brasil: Um País de Negros?. Rio de Janeiro: Pallas, 1999. p. 221-234.

SANTOS, Ivair Augusto Alves dos. Direitos humanos e as práticas de racismo. Brasília: Edição Câmara dos Deputados, 2015.

SANTOS, R. da C.; SOUZA, E.P. SEPPIR - Promovendo a igualdade racial para um Brasil sem racismo. Brasília: SEPPIR/PR, 2016.

SANTOS, Sales Augustos dos, MORENO, J.V.; BERTÚlIO, D.L. O processo de aprovação do Estatuto da Igualdade Racial, Lei 12288, de 20 julho de 2010. Brasília: INESC, 2011.

SANTOS, Sales Augusto dos. Movimentos negros, educação e ações afirmativas. $2^{\mathrm{a}}$ Edição. 2009.

O Sistema de cotas para negros na UnB: um balanço da primeira geração. Jundiaí: Paco Editorial, 2015.

SELL, Carlos Eduardo. Introdução à Sociologia Política: política e sociedade na modernidade tardia. Petrópolis, RJ: Vozes, 2006.

SILVA, Cidinha da (Org.). Ações Afirmativas em educação: experiências brasileiras. São Paulo: Summus, 2003.

SILVA Jr., Hédio. Anti-racismo-coletânea de leis brasileiras: federais, estaduais e municipais. São Paulo: Oliveira Mendes, 1997.

SILVA, Silvio Jose Albuquerque e. Combate ao racismo. Brasília: Fundação Alexandre Gusmão, 2008.

SILVA, Tatiana D. Gestão Pública na zona do não-ser: políticas públicas de promoção da igualdade racial na administração pública federal no Brasil. 2016 (memo). 
SILVA, Tatiana D. Ação Afirmativa para ingresso de negros no Ensino Superior: a formação da agenda governamental segundo atores-chave. In: Encontro da Associação Nacional de PósGraduação e Pesquisa em Administração (EnANPAD. XL, 2016, Bahia. Anais... Bahia, 2016.

SILVÉRIO, Valter Roberto. Ação Afirmativa e o combate ao racismo institucional no Brasil. Cadernos de Pesquisa, n. 117, p. 219-246, nov., 2002.

SILVÉRIO, Valter Roberto; MOEHLECKE, Sabrina (Ed.). Ações afirmativas nas políticas educacionais: o contexto pós-Durban. São Carlos: EDUFSCAR 2009.

SOUZA, Celina et al. Políticas públicas: uma revisão da literatura. Sociologias, v. 8, n. 16, p. 20-45, 2006.

SOUZA NETO, Cláudio Pereira de; FERES JR, João. Ação afirmativa: normatividade e constitucionalidade. Igualdade, diferença e direitos humanos. Rio de Janeiro: Lumen Juris, p. 345-363, 2008.

THEODORO, Mário (Org.). As políticas públicas e a desigualdade racial no Brasil: 120 anos após a abolição. Brasília: IPEA, 2008.

WERNECK, Jurema et al. Racismo institucional: uma abordagem conceitual. Rio de Janeiro: Instituto Geledés, 2013. 


\section{ANEXOS}

ANEXO 1 - Redação final - Projeto de Lei Nº 73-C de 1999 - Plenário Câmara dos Deputados

ANEXO 2 - Redação Final - Parecer n ${ }^{\circ}$ 1.005, de 2012 - Plenário do Senado Federal ANEXO 3 - Manifesto MSU a favor da Lei de Cotas

ANEXO 4 - Manifesto contra as cotas raciais

ANEXO 5 - Anexo 5 - Manifesto a favor das Cotas 


\section{ANEXO 1}

Redação final - Projeto de Lei No 73-C de 1999 - Plenário Câmara dos Deputados

\section{REDAÇĀO FINAL}

PROJETO DE LEI N ${ }^{\circ} 73-C$ DE 1999

D1spóe sobre $\circ$ ingresso nas universidades federais e estaduals e nas inst1tulçóes federals de ensino técnico de nível mếdio e dá outras providênclas.

- CONGRESSO NACIONAL decreta:

Art. $1^{\circ}$ As 1nstituiçóes federals de educaçåo superior vinculadas ao Ministêrio da Educaçăo reservarăo em cada concurso selet1vo para 1ngresso nos cursos de graduaçăo, por curso e turno, no mínimo $50 \%$ (cinqüenta por cento) de suas vagas para estudantes que tenham cursado integralmente $\circ$ ensino méd1o em escolas públicas.

parăgrafo único. No preenchimento das vagas de que trata o caput deste art1go, 508 (c1nqüenta por cento) deverăo ser reservados aos estudantes orlundos de famillas com renda 1gual ou inferior a 1,5 salárto mínimo per capita.

Art. $2^{\circ}$ As universidades públicas deverăo selectonar os alunos advindos do ensino mêdio em escolas públicas tendo como base o coeficiente de Rendimento - $\mathrm{CR}$, obtido por melo de média arıtmétıca das notas ou mençбes obtidas no período, considerando-se o currículo comum a ser estabelecido pelo Ministếrıo da Bducaçăo e do Desporto.

Parăgrafo único. As institulçס̄es privadas de ensino superior poder a adotar o procedimento descrito no caput deste artigo em seus exames de 1ngresso.

Art. $3^{\circ} \mathrm{km}$ cada 1nstitulçăo federal de ensino super1or, as vagas de que trata $\circ$ art. $1^{\circ}$ desta Le1 seråo preenchldas, por curso e turno, por autodeclarados negros, pardos e 1ndígenas, no mín1mo 1gual à proporçăo de negros, pardos e in- 
dígenas na populaçåo da unidade da Federaçăo onde está Instalada a 1nstitu1çăo, segundo o último censo da Fundaçăo Inst1tuto Brasile1ro de Geografia e Estatíst1ca - IBGB.

Parágrafo ún1co. No caso de năo-preench1mento das vagas segundo os critếrios estabelecidos no caput deste artigo, aquelas remanescentes deverăo ser completadas por estudantes que tenham cursado integralmente o ensino médio em escolas públicas.

Art. $4^{\circ}$ As 1nstitulçő́es federa1s de ensino tếcnico de nível médio reservarăo em cada concurso selet1vo para 1ngresso de cada curso, por turno, no mínimo $50 \%$ (cinqüenta por cento) de suas vagas para estudantes que cursaram integralmente $\circ$ ensino fundamental em escolas públicas.

Parăgrafo único. No preenchimento das vagas de que trata o caput deste art1go, 508 (c1nqüenta por cento) deverăo ser reservados aos estudantes orlundos de famillas com renda 1gual ou 1nferior a 1,5 salário mínimo per capita.

Art. $5^{\circ} \mathrm{km}$ cada institulçăo federal de ensino tếcnico de nível méd1o, as vagas de que trata $\circ$ art. $4^{\circ}$ desta Le1 seråo preenchldas, por curso e turno, por autodeclarados negros, pardos e 1ndígenas, no míntmo 1gual à proporçăo de negros, pardos e indígenas na populaçăo da unidade da Federaçăo onde está 1nstalada a 1nstitu1çăo, segundo o último censo da Fundaçăo Instituto Brasileiro de Geografia e Estatística IBGB .

Parágrafo ún1co. No caso de năo-preenchimento das vagas segundo os critêrios estabelecılos no caput deste artıgo, aquelas remanescentes deverăo ser preenchldas por estudantes que tenham cursado integralmente o ensino fundamental em escola públlca. 
Art. $6^{\circ} \circ$ Ministêrio da Educaçăo e a secretaria kspeclal de políticas de promoçăo da Igualdade Raclal da presidênc1a da República serăo responsávels pelo acompanhamento e ava11 açăo do programa de que trata esta Le1, ouvida a Fundaçăo Nacional do Índ1o - PUNAI.

Art. $7^{\circ} \circ$ poder Executivo promoverá, no prazo de 10 (dez) anos, a contar da publicaçăo desta Le1, a revisăo do programa especial para o acesso de estudantes negros, pardos e Indígenas, bem como daqueles que tenham cursado integralmente - ensino médio em escolas públicas, nas 1nst1tulçס̄es de educaçăo supertor.

Art. $8^{\circ}$ As 1nstitulçóes de que trata $\circ$ art. $1^{\circ}$ desta Le1 deverå 1mplementar, no minimo, 258 (v1nte e cinco por cento) da reserva de vagas prevista nesta Le1, a cada ano, e teråo o prazo máximo de 4 (quatro) anos, a partir da data de sua publicaçåo, para o cumprimento integral do disposto nesta Le1.

Art. $9^{\circ}$ Esta Le1 entra em vigor na data de sua publ1caçăo.

Sala das sessōes, em 20 de novembro de 2008 . 


\section{ANEXO 2}

Redação Final - Parecer nº 1.005, de 2012 - Plenário do Senado Federal

\section{COMISSÃO DIRETORA}

\section{PARECER N ${ }^{\circ} 1.005$, DE 2012}

Redação final do Projeto de Lei da Câmara $n^{\circ} 180$, de $2008\left(n^{\circ} 73\right.$, de 1999, na Casa de origem).

A Comissão Diretora apresenta a redação final do Projeto de Lei da Câmara $n^{\circ}$ 180 , de 2008 ( $\mathrm{n}^{\circ} 73$, de 1999, na Casa de origem), que dispõe sobre o ingresso nas universidades federais e estaduais e nas instituições federais de ensino técnico de nivel médio e dá outras providencias, consolidando as Emendas n ${ }^{\circ}$ s 1 e $2-\mathrm{CCJ} / \mathrm{CDH}$ e 3 e $4-\mathrm{CDH}$, todas de redação, aprovadas pelo Plenário.

Sala de Reuniões da Comissão, em 7 de agosto de 2012. 
Redação final do Projeto de Lei da Câmara $\mathrm{n}^{\circ} 180$, de 2008 ( $\mathrm{n}^{\circ} 73$, de 1999 , na Casa de origem).

Dispõe sobre $\circ$ ingresso nas universidades federais e nas instituições federais de ensino técnico de nível médio e dá outras providências.

\section{O CONGRESSO NACIONAL decreta:}

Art. $1^{\circ}$ As instituições federais de educação superior vinculadas ao Ministério da Educação reservarão, em cada concurso seletivo para ingresso nos cursos de graduação, por curso e turno, no mínimo $50 \%$ (cinquenta por cento) de suas vagas para estudantes que tenham cursado integralmente o ensino médio em escolas públicas.

Parágrafo único. No preenchimento das vagas de que trata o caput deste artigo, $50 \%$ (cinquenta por cento) deverão ser reservados aos estudantes oriundos de famílias com renda igual ou inferior a 1,5 salário-mínimo (um salário-mínimo e meio) per capita.

Art. $2^{\circ}$ As universidades públicas deverão selecionar os alunos advindos do ensino médio em escolas públicas tendo como base o Coefíciente de Rendimento (CR), obtido por meio de média aritmética das notas ou menções obtidas no período, considerando-se o currículo comum a ser estabelecido pelo Ministério da Educação.

Parágrafo único. As instituições privadas de ensino superior poderão adotar o procedimento descrito no caput deste artigo em seus exames de ingresso.

Art. $3^{\circ} \mathrm{Em}$ cada instituição federal de ensino superior, as vagas de que trata 0 art. $1^{\circ}$ desta Lei serão preenchidas, por curso e turno, por autodeclarados pretos, pardos e indígenas, em proporção no mínimo igual à de pretos, pardos e indígenas na população da unidade da Federação onde está instalada a instituição, segundo o último censo do Instituto Brasileiro de Geografia e Estatística (IBGE).

Parágrafo único. No caso de não preenchimento das vagas segundo os critérios estabelecidos no caput deste artigo, aquelas remanescentes deverão ser completadas por estudantes que tenham cursado integralmente o ensino médio em escolas públicas.

Art. $4^{\circ}$ As instituições federais de ensino técnico de nível médio reservarão, em cada concurso seletivo para ingresso em cada curso, por turno, no mínimo $50 \%$ (cinquenta por cento) de suas vagas para estudantes que cursaram integralmente o ensino fundamental em escolas públicas. 
Parágrafo único. No preenchimento das vagas de que trata o caput deste artigo, $50 \%$ (cinquenta por cento) deverão ser reservados aos estudantes oriundos de famílias com renda igual ou inferior a 1,5 salário-mínimo (um salário-mínimo e meio) per capita.

Art. $5^{\circ} \mathrm{Em}$ cada instituição federal de ensino técnico de nível médio, as vagas de que trata o art. $4^{\circ}$ desta Lei serão preenchidas, por curso e turno, por autodeclarados pretos, pardos e indígenas, em proporção no mínimo igual à de pretos, pardos e indígenas na população da unidade da Federação onde está instalada a instituição, segundo o último censo do Instituto Brasileiro de Geografia e Estatística (IBGE).

Parágrafo único. No caso de não preenchimento das vagas segundo os critérios estabelecidos no caput deste artigo, aquelas remanescentes deverão ser preenchidas por estudantes que tenham cursado integralmente o ensino fundamental em escola pública.

Art. $6^{\circ} \mathrm{O}$ Ministério da Educação e a Secretaria Especial de Políticas de Promoção da Igualdade Racial, da Presidência da República, serão responsáveis pelo acompanhamento e avaliação do programa de que trata esta Lei, ouvida a Fundação Nacional do Índio (Funai).

Art. $7^{\circ} \mathrm{O}$ Poder Executivo promoverá, no prazo de $10(\mathrm{dez})$ anos, a contar da publicação desta Lei, a revisão do programa especial para o acesso de estudantes pretos, pardos e indígenas, bem como daqueles que tenham cursado integralmente o ensino médio em escolas públicas, às instituições de educação superior.

Art. $8^{\circ}$ As instituições de que trata o art. $1^{\circ}$ desta Lei deverão implementar, no mínimo, $25 \%$ (vinte e cinco por cento) da reserva de vagas prevista nesta Lei, a cada ano, e terão o prazo máximo de 4 (quatro) anos, a partir da data de sua publicação, para o cumprimento integral do disposto nesta Lei.

Art. $9^{\circ}$ Esta Lei entra em vigor na data de sua publicação. 


\section{ANEXO 3}

Manifesto MSU a favor da Lei de Cotas

\section{Um brinde às cotas: manifesto pela alegria, pela dignidade e pela fé no Brasil. Enfim, vencemos! Em 10 anos não seremos os sem universidade!}

Brasilia, 13 de agosto de 2012.

Dedimos licença para falar. Valei-nos Sáo Jorge, o MSU pede passagem. Na humildade. Temos um grito de alegria nas gargantas, em nossas entranhas, em nossos coraçōes, em nossas mentes, em nossos corpos, em nossas almas. Vival Muitos vivas! É festa no Brasill As cotas foram aprovadas no Senado Federal em 07 de agosto de 2012. Nós estávamos lá. Por longos anos de disputa o MSU esteve sempre là. (...)

Força da sociedade civil, que obriga o Estado a fazer justiça, a cumprir a Constituiçâo. É um grito negro! Um grito indigena! Um grito do coro brasileiro da escola pública, o pai, a mae, o filho, a professora, o professor, a diretora, os trabalhadores, os amigos da rua, os vizinhos. (...)

Nova classe média, dizem. Baita apelido. Trabalhadores e trabalhadoras somos frutos da labuta diaria dos nossos, muito fora da zona de conforto da elite brasileira. Continuamos a luta dos quilombos, a luta da educaçào popular, a luta dos excedentes dos anos 1960. Somos os Sem Universidade, sem hifen. Inventamos o Prouni, na luta. Mas nào somos bobos. Se vale para as privadas, tem que valer para as públicas. Nao pode haver cidadăos de segunda categoria no Brasil. Somos homens e mulheres das periferias brasileiras, sujeitos da história, sujeitos de direito. (...)

E mais. Mandamos flores. Como os abolicionistas, camelias brancas $e$ o que oferecemos para toda a população brasileira. Paz. Năo levaremos mágoa, rancor e ódio nem semearemos isto. Isso nâo é da nossa laia. Se as cotas vâo atrapalhar alguns negocios da educaçào como mercadoria, nào pensamos nisso. Educaçăo é um bem público, condiçăo sem a qual năo há desenvolvimento sustentável do Brasill, nem coesão social. Estamos esgotados de ver as mortes de nossos irmàos jovens, vitimas da violência. Viva as cotas. Viva os $50 \%$ para a escola pública, por turno e por curso, respeitando-se a proporçào de negros e indigenas por regiâo. Desfaz-se um nó cego histórico e uma trama das elites brasileiras contra seu próprio povo. Libertam-se as forças criativas e intelectuais, os talentos de homens e mulheres brasileiros simples, antes proibidos de frequentar a universidade pública, suas principais carreiras e cursos. Esse bastào ira de geraçăo a geraçào. O Brasil nunca mais será o mesmo. Entra em campo um novo time, que com certeza nào fara felo na tarefa de ajudar o Brasil na superaçào de suas desigualdades sociais, porque conhecimento é poder e esse novo poder mudará a cara do Brasil.

Movimento dos Sem Universidade (MSU) www.msu.org.br 


\author{
ANEXO 4 \\ Manifesto contra as cotas raciais
}

\title{
CARTA PÚBLICA AO CONGRESSO NACIONAL
}

\section{Todos têm direitos iguais na República Democrática}

O princípio da igualdade política e jurídica dos cidadãos é um fundamento essencial da República e um dos alicerces sobre o qual repousa a Constituição brasileira. Este princípio encontra-se ameaçado de extinção por diversos dispositivos dos projetos de lei de Cotas (PL 73/1999) e do Estatuto da Igualdade Racial (PL 3.198/2000) que logo serão submetidos a uma decisão final no Congresso Nacional.

O PL de Cotas torna compulsória a reserva de vagas para negros e indígenas nas instituições federais de ensino superior. O chamado Estatuto da Igualdade Racial implanta uma classificação racial oficial dos cidadãos brasileiros, estabelece cotas raciais no serviço público e cria privilégios nas relações comerciais com o poder público para empresas privadas que utilizem cotas raciais na contratação de funcionários. Se forem aprovados, a nação brasileira passará a definir os direitos das pessoas com base na tonalidade da sua pele, pela "raça". A história já condenou dolorosamente estas tentativas.

Os defensores desses projetos argumentam que as cotas raciais constituem política compensatória voltada para amenizar as desigualdades sociais. O argumento é conhecido: temos um passado de escravidão que levou a população de origem africana a níveis de renda e condições de vida precárias. O preconceito e a discriminação contribuem para que esta situação pouco se altere. Em decorrência disso, haveria a necessidade de políticas sociais que compensassem os que foram prejudicados no passado, ou que herdaram situações desvantajosas. Essas políticas, ainda que reconhecidamente imperfeitas, se justificariam porque viriam a corrigir um mal maior. Esta análise não é realista nem sustentável e tememos as possíveis conseqüências das cotas raciais. Transformam classificações estatísticas gerais (como as do IBGE) em identidades e direitos individuais contra o preceito da igualdade de todos perante a lei.

A adoção de identidades raciais não deve ser imposta e regulada pelo Estado. Políticas dirigidas a grupos "raciais" estanques em nome da justiça social não eliminam o racismo e podem até mesmo produzir o efeito contrário, dando respaldo legal ao conceito de raça, e possibilitando o acirramento do conflito e da intolerância. A verdade amplamente reconhecida é que o principal caminho para o combate à exclusão social é a construção de serviços públicos universais de qualidade nos setores de educação, saúde e previdência, em especial a criação de empregos. Essas metas só poderão ser alcançadas pelo esforço comum de cidadãos de todos os tons de pele contra privilégios odiosos que limitam o alcance do princípio republicano da igualdade política e jurídica. A invenção de raças oficiais tem tudo para semear esse perigoso tipo de racismo, como demonstram exemplos históricos e contemporâneos. E ainda bloquear o caminho para a resolução real dos problemas de desigualdades. 
Qual Brasil queremos? Almejamos um Brasil no qual ninguém seja discriminado, de forma positiva ou negativa, pela sua cor, seu sexo, sua vida íntima e sua religião; onde todos tenham acesso a todos os serviços públicos; que se valorize a diversidade como um processo vivaz e integrante do caminho de toda a humanidade para um futuro onde a palavra felicidade não seja um sonho. Enfim, que todos sejam valorizados pelo que são e pelo que conseguem fazer. Nosso sonho é o de Martin Luther King, que lutou para viver numa nação onde as pessoas não seriam avaliadas pela cor de sua pele, mas pela força de seu caráter.

Nos dirigimos ao congresso nacional, seus deputados e senadores, pedindo-lhes que recusem o PL 73/1999 (PL das Cotas) e o PL 3.198/2000 (PL do Estatuto da Igualdade Racial) em nome da República Democrática.

Rio de Janeiro, 30 de maio de 2006.

Adel Daher Filho - Diretor do Sindicato dos Ferroviários de SP-Bauru/MS e MT Adilson Mariano - Vereador PT Joinville (SC)

Alberto Aggio - Professor livre-docente de História, UNESP/campus de Franca Alberto de Mello e Souza - Faculdade de Ciências Econômicas da UERJ

Almir da Silva Lima - Jornalista, MOMACUNE (Movimento Macaense Culturas Negras, Macaé-RJ)

Amandio Gomes - Professor do Instituto de Psicologia da UFRJ e do PPGHC (IFCSUFRJ) Ana Teresa Venancio - Antropóloga, pesquisadora da Casa de Oswaldo Cruz/Fiocruz André Campos - Professor do Departamento de História da UFF e da UERJ

André Côrtes de Oliveira - Professor

Angela Porto - Historiadora, Pesquisadora do Departamento de Pesquisa da Casa de Oswaldo Cruz/Fiocruz

Anna Veronica Mautner - Psicanalista da Sociedade Brasileira de Psicanálise de

S.Paulo e colunista da Folha de S. Paulo.

Antonio Carlos Jucá de Sampaio, Professor Adjunto do Departamento de História -

UFRJ

Antonio Cícero - Poeta e ensaísta

Antonio Marques Cardoso (Ferreirinha) - Fábrica Cipla (Ocupada pelos

Trabalhadores), Joinville/SC

Aurélio Carlos Marques de Moura - Presidente do Conselho Municipal de Cultura da

Serra (ES) e da Associação Cultural Afro-brasileira "Ibó de Zambi".

Bernardo Kocher - Professor Departamento de História da UFF

Bernardo Sorj - Professor titular de sociologia UFRJ

Bila Sorj - Professora titular de sociologia UFRJ

Bolivar Lamounier - Cientista Político

Cacilda da Silva Machado - Professora do Departamento de História da UFPR (PR)

Caetano Veloso

Carlos Costa Ribeiro - Professor; atuou como especialista contratado no Programa das

Nações Unidas Para o Meio Ambiente - PNUMA/UNEP

Claudia Travassos - Pesquisadora Titular da Fundação Oswaldo Cruz

Cláudia Wasserman - Professora Adjunta de História da UFRGS

Celia Maria Marinho de Azevedo - Historiadora

Célia Tavares - Professora Adjunta de História (FFP/UERJ)

Cyro Borges Jr. - Professor Adjunto do Departamento de Engenharia Mecânica da 


\section{UERJ}

Darcy Fontoura de Almeida - Professor Emérito, UFRJ

Demétrio Magnoli - Sociólogo e articulista da Folha de S. Paulo

Dilene Nascimento - Historiadora, pesquisadora da Casa de Oswaldo Cruz/Fiocruz

Domingos de Leers Guimaraens - Artista Visual

Dominichi Miranda de Sá - Pesquisadora da Fundação Oswaldo Cruz

Egberto Gaspar de Moura - Professor Titular de Fisiologia, Instituto de Biologia, UERJ

Elvira Carvajal - Professora de Biologia Molecular e Genética, UERJ

Eunice R. Durham - Professora titular de Antropologia, Professora emérita da FFLCH da USP

Fabiano Gontijo - Professor Adjunto de Antropologia, Departamento de Ciências

Sociais, Programa de Pós-Graduação em Políticas Públicas, Programa de Pós-

Graduação em Letras, UFPI

Fernanda Martins - Pesquisadora da Fundação Oscar Niemayer (RJ)

Fernando Roberto de Freitas Almeida - Coordenador do curso de Economia da

Faculdade Moraes Junior/Universidade Presbiteriana Mackenzie-Rio.

Ferreira Gullar - Poeta

Francisco Martinho - Professor de História da UERJ

George de Cerqueira Leite Zarur - Professor Internacional da Flacso e Consultor

Legislativo da Área de Educação Superior da Câmara dos Deputados

Gilberto Hochman - Cientista Político pesquisador da Casa de Oswaldo

Cruz/FIOCRUZ

Gilberto Velho - Professor titular e decano do Departamento de Antropologia do

Museu Nacional da Universidade Federal do Rio de Janeiro e membro da Academia

Brasileira de Ciências

Gilda Portugal - Professora de Sociologia da UNICAMP

Gilson Schwartz - Economista, Professor de Economia da Informação da ECA-USP e

Diretor da Cidade do Conhecimento (USP)

Giselda Brito - Professora Adjunta de História da Universidade Federal Rural

de Pernambuco

Gláucia K. Villas Boas - Vice-Diretora do IFCS/UFRJ e professora do departamento de Sociologia da UFRJ

Guilherme Amaral Luz - Professor do Instituto de História da UFU

Guita Debert - Professora Titular de Antropologia do Departamento de Antropologia UNICAMP

Helena Lewin - Professora Titular aposentada da UFF

Hercidia Mara Facuri Coelho - Pró-reitora, Universidade de Franca (UNIFRAN)

Hugo Rogélio Suppo - Professor adjunto de História da UERJ

Icléia Thiesen - Professora Adjunta do Programa de Pós-graduação em Memória

Social da UNI-Rio

Isabel Lustosa - Pesquisadora Titular da Fundação Casa de Rui Barbosa

João Amado - Mestrando em História da UERJ e professor da rede pública

João Leão Sattamini Netto - Economista, membro do Conselho de Cultura do Estado do

Rio de Janeiro, Comodante do Museu de Arte Contemporânea de Niterói.

João Paulo Coelho de Souza Rodrigues - DECIS, UFSJ

John Michael Norvell - Professor Visitante, Pitzer College, Claremont, CA EUA

José Augusto Drummond - Cientista político, professor do Centro de Desenvolvimento

Sustentável (CDS/UnB) 
José Carlos Miranda - Diretório Estadual do PT SP, Coordenação do Comitê por um Movimento Negro Socialista (MNS)

José Roberto Ferreira Militão - Advogado, AFROSOL-LUX - Promotora de Soluções em Economia Solidária

José Roberto Pinto de Góes - Professor de História da UERJ

Josué Pereira da Silva - Professor de sociologia, IFCH, UNICAMP

Kátia Maciel - N-Imagem - Escola de Comunicação da UFRJ

Kenneth Rochel de Camargo Jr. - Professor Adjunto do Instituto de Medicina Social da UERJ

Laiana Lannes de Oliveira - Professora de História da PUC (RJ)

Lena Lavinas - Professora do Instituto de Economia da UFRJ

Lilia K. Moritz Schwarcz - Professora Titular de Antropologia da USP

Lucia Lippi Oliveira - Socióloga, pesquisadora e professora do CPDOC/FGV

Lúcia Schmidt - Professora Adjunta da Faculdade de Engenharia da UERJ.

Luciana da Cunha Oliveira - Mestranda em História pela UFF e professora

da rede pública de ensino

Luiz Alphonsus de Guimaraens - Artista Plástico

Luiz Fernando Almeida Pereira - Professor de Sociologia da PUC-Rio

Luiz Fernando Dias Duarte - Professor do Departamento de Antropologia do Museu

Nacional da UFRJ

Luiz Werneck Vianna - Professor titular do IUPERJ

Madel T. Luz - Professora Titular do Instituto de Medicina Social da UERJ

Magali Romero Sá - Historiadora, Pesquisadora da Casa de Oswaldo Cruz/FIOCRUZ

Manolo Florentino - Professor de história, IFCS/UFRJ

Marcos Chor Maio - Sociólogo, Fundação Oswaldo Cruz

Maria Alice Resende de Carvalho - Socióloga, professora do IUPERJ

Maria Conceição Pinto de Góes - Pós-Graduação em História Comparada, UFRJ.

Maria Hermínia Tavares de Almeida - Professora Titular de Ciência Política da USP

Maria Sylvia de Carvalho Franco - Professora Titular de Filosofia, Unicamp

Mariza Peirano - Professora titular de antropologia, UnB

Mirian Goldenberg - Professora de Antropologia IFCS-UFRJ

Moacyr Góes - Diretor de cinema e teatro

Mônica Grin - Professora do departamento de História da UFRJ

Monique Franco - Professora FFP/UERJ

Nisia Trindade Lima - Socióloga, Fundação Oswaldo Cruz

Oliveiros S. Ferreira - Professor de Política na PUC-SP e USP-SP

Paulo Kramer - Professor do Departamento de Ciência Política da UnB

Peter Fry - Professor titular de antropologia UFRJ

Priscilla Mouta Marques - Professora de Português e Literaturas Brasileira e

Africanas de Língua Portuguesa, auxiliar de pesquisa da Fundação Oswaldo Cruz.

Ronaldo Vainfas - Professor Titular de História Moderna da Universidade Federal

Fluminense

Renata da Costa Vaz - Diretora do Sindicato Servidores Públicos Municipais

Campinas/SP

Renato Lessa - Professor titular do IUPERJ

Ricardo Ventura Santos - Pesquisador da Fundação Oswaldo Cruz e Professor do

Departamento de Antropologia do Museu Nacional, UFRJ

Rita de Cássia Fazzi - Professora do Departamento de Ciências Sociais da PUC (MG)

Roberto Romano - Professor Titular de Filosofia, Unicamp 
Roney Cytrynowicz - Historiador

Roque Ferreira - Coordenador Nacional da Federação dos Trabalhadores sobre

Trilhos - CUT, Conselho Comunidade Negra Bauru-SP

Serge Goulart - Integrante do Diretório Nacional do PT

Sergio Danilo Pena - Professor Titular do Depto. Bioquímica e Imunologia da UFMG

Silvana Santiago - historiadora

Silvia Figueiroa - Historiadora, Professora do Instituto de Geociências da UNICAMP

Simon Schwartzman - Presidente do Instituto de Estudos do Trabalho e Sociedade no

Rio de Janeiro

Simone Monteiro - Pesquisadora da Fundação Oswaldo Cruz

Ubiratan Iorio - Professor Adjunto da UERJ e Presidente do Centro Interdisciplinar de

Ética e Economia Personalista (Cieep)

Uliana Dias Campos Ferlim - Cantora e professora, mestre em história

Vicente Palermo - Instituto Gino Germani, Buenos Aires, Conicet, Argentina.

Wanderley Guilherme dos Santos - Cientista político

6

Wlamir José da Silva - Professor Adjunto de História da Universidade Federal de São

João del-Rei (UFSJ)

Yvonne Maggie - Professora titular de antropologia IFCS/UFRJ

Zelito Vianna - Cineasta

\section{3 cidadãos anti-racistas contra as cotas}

Excelentíssimo Sr. Ministro,

Duas ações diretas de inconstitucionalidade (ADI 3.330 e ADI 3.197) promovidas pela Confederação Nacional dos Estabelecimentos de Ensino (Confenen), a primeira contra o programa PROUNI e a segunda contra a lei de cotas nos concursos vestibulares das universidades estaduais do Rio de Janeiro, serão apreciadas proximamente pelo STF. Os julgamentos terão significado histórico, pois podem criar jurisprudência sobre a constitucionalidade de cotas raciais não só para o financiamento de cursos no ensino superior particular e para concursos de ingresso no ensino superior público como para concursos públicos em geral. Mais ainda: os julgamentos têm o potencial de enviar uma mensagem decisiva sobre a constitucionalidade da produção de leis raciais.

Nós, intelectuais da sociedade civil, sindicalistas, empresários e ativistas dos movimentos negros e outros movimentos sociais, dirigimo-nos respeitosamente aos Juízes da corte mais alta, que recebeu do povo constituinte a prerrogativa de guardiã da Constituição, para oferecer argumentos contrários à admissão de cotas raciais na ordem política e jurídica da República.

Na seara do que Vossas Excelências dominam, apontamos a Constituição Federal, no seu Artigo 19, que estabelece: "É vedado à União, aos Estados, ao Distrito Federal e aos Municípios criar distinções entre brasileiros ou preferências entre si”. O Artigo 208 dispõe que: "O dever do Estado com a educação será efetivado mediante a garantia de acesso aos níveis mais elevados do ensino, da pesquisa e da criação artística, segundo a capacidade de cada um". Alinhada com os princípios e garantias da Constituição Federal, a Constituição Estadual do Rio de Janeiro, no seu Artigo 9, § $1^{\circ}$, determina 
que: "Ninguém será discriminado, prejudicado ou privilegiado em razão de nascimento, idade, etnia, raça, cor, sexo, estado civil, trabalho rural ou urbano, religião, convicções políticas ou filosóficas, deficiência física ou mental, por ter cumprido pena nem por qualquer particularidade ou condição".

As palavras da Lei emanam de uma tradição brasileira, que cumpre exatos 120 anos desde a Abolição da escravidão, de não dar amparo a leis e políticas raciais. No intuito de justificar o rompimento dessa tradição, os proponentes das cotas raciais sustentam que o princípio da igualdade de todos perante a lei exige tratar desigualmente os desiguais. Ritualmente, eles citam a Oração aos Moços, na qual Rui Barbosa, inspirado em Aristóteles, explica que: "A regra da igualdade não consiste senão em aquinhoar desigualmente aos desiguais, na medida em que se desigualam. Nesta desigualdade social, proporcionada à desigualdade natural, é que se acha a verdadeira lei da igualdade." O método de tratar desigualmente os desiguais, a que se refere, é aquele aplicado, com justiça, em campos tão distintos quanto o sistema tributário, por meio da tributação progressiva, e as políticas sociais de transferência de renda. Mas a sua invocação para sustentar leis raciais não é mais que um sofisma.

Os concursos vestibulares, pelos quais se dá o ingresso no ensino superior de qualidade "segundo a capacidade de cada um", não são promotores de desigualdades, mas se realizam no terreno semeado por desigualdades sociais prévias. A pobreza no Brasil tem todas as cores. De acordo com dados da Pesquisa Nacional por Amostra de Domicílios (PNAD) de 2006, entre 43 milhões de pessoas de 18 a 30 anos de idade, 12,9 milhões tinham renda familiar per capita de meio salário mínimo ou menos. Neste grupo mais pobre, $30 \%$ classificavam-se a si mesmos como "brancos", $9 \%$ como "pretos", e $60 \%$ como "pardos". Desses 12,9 milhões, apenas 21\% dos "brancos" e 16\% dos "pretos" e "pardos" haviam completado o ensino médio, mas muito poucos, de qualquer cor, continuaram estudando depois disso. Basicamente, são diferenças de renda, com tudo que vem associado a elas, e não de cor, que limitam o acesso ao ensino superior.

Apresentadas como maneira de reduzir as desigualdades sociais, as cotas raciais não contribuem para isso, ocultam uma realidade trágica e desviam as atenções dos desafios imensos e das urgências, sociais e educacionais, com os quais se defronta a nação. E, contudo, mesmo no universo menor dos jovens que têm a oportunidade de almejar o ensino superior de qualidade, as cotas raciais não promovem a igualdade, mas apenas acentuam desigualdades prévias ou produzem novas desigualdades:

As cotas raciais exclusivas, como aplicadas, entre outras, na Universidade de Brasília (UnB), proporcionam a um candidato definido como "negro" a oportunidade de ingresso por menor número de pontos que um candidato definido como "branco", mesmo se o primeiro provém de família de alta renda e cursou colégios particulares de excelência e o segundo provém de família de baixa renda e cursou escolas públicas arruinadas. No fim, o sistema concede um privilégio para candidatos de classe média arbitrariamente classificados como "negros".

As cotas raciais embutidas no interior de cotas para candidatos de escolas públicas, como aplicadas, entre outras, pela Universidade Estadual do Rio de Janeiro (UERJ), separam os alunos proveniente de famílias com faixas de renda semelhantes em dois grupos "raciais" polares, gerando uma desigualdade "natural" num meio caracterizado 
pela igualdade social. O seu resultado previsível é oferecer privilégios para candidatos definidos arbitrariamente como "negros" que cursaram escolas públicas de melhor qualidade, em detrimento de seus colegas definidos como "brancos" e de todos os alunos de escolas públicas de pior qualidade.

A PNAD de 2006 informa que 9,41 milhões de estudantes cursavam o ensino médio, mas apenas 5,87 milhões frequientavam o ensino superior, dos quais só uma minoria de 1,44 milhão estavam matriculados em instituições superiores públicas. As leis de cotas raciais não alteram em nada esse quadro e não proporcionam inclusão social. Elas apenas selecionam "vencedores" e "perdedores", com base num critério altamente subjetivo e intrinsecamente injusto, abrindo cicatrizes profundas na personalidade dos jovens, naquele momento de extrema fragilidade que significa a disputa, ainda imaturos, por uma vaga que lhes garanta o futuro.

Queremos um Brasil onde seus cidadãos possam celebrar suas múltiplas origens, que se plasmam na criação de uma cultura nacional aberta e tolerante, no lugar de sermos obrigados a escolher e valorizar uma única ancestralidade em detrimento das outras. O que nos mobiliza não é o combate à doutrina de ações afirmativas, quando entendidas como esforço para cumprir as Declarações Preambulares da Constituição, contribuindo na redução das desigualdades sociais, mas a manipulação dessa doutrina com o propósito de racializar a vida social no país. As leis que oferecem oportunidades de emprego a deficientes físicos e que concedem cotas a mulheres nos partidos políticos são invocadas como precedentes para sustentar a admissibilidade jurídica de leis raciais. Esse segundo sofisma é ainda mais grave, pois conduz à naturalização das raças. Afinal, todos sabemos quem são as mulheres e os deficientes físicos, mas a definição e delimitação de grupos raciais pelo Estado é um empreendimento político que tem como ponto de partida a negação daquilo que nos explicam os cientistas.

Raças humanas não existem. A genética comprovou que as diferenças icônicas das chamadas "raças" humanas são características físicas superficiais, que dependem de parcela ínfima dos 25 mil genes estimados do genoma humano. A cor da pele, uma adaptação evolutiva aos níveis de radiação ultravioleta vigentes em diferentes áreas do mundo, é expressa em menos de 10 genes! Nas palavras do geneticista Sérgio Pena: "O fato assim cientificamente comprovado da inexistência das 'raças' deve ser absorvido pela sociedade e incorporado às suas convicções e atitudes morais Uma postura coerente e desejável seria a construção de uma sociedade desracializada, na qual a singularidade do indivíduo seja valorizada e celebrada. Temos de assimilar a noção de que a única divisão biologicamente coerente da espécie humana é em bilhões de indivíduos, e não em um punhado de "raças'." ("Receita para uma humanidade desracializada", Ciência Hoje Online, setembro de 2006).

Não foi a existência de raças que gerou o racismo, mas o racismo que fabricou a crença em raças. O "racismo científico" do século XIX acompanhou a expansão imperial européia na África e na Ásia, erguendo um pilar "científico" de sustentação da ideologia da "missão civilizatória" dos europeus, que foi expressa celebremente como o "fardo do homem branco".

Os poderes coloniais, para separar na lei os colonizadores dos nativos, distinguiram também os nativos entre si e inscreveram essas distinções nos censos. A distribuição de 
privilégios segundo critérios etno-raciais inculcou a raça nas consciências e na vida política, semeando tensões e gestando conflitos que ainda perduram. Na África do Sul, o sistema do apartheid separou os brancos dos demais e foi adiante, na sua lógica implacável, fragmentando todos os "não-brancos" em grupos étnicos cuidadosamente delimitados. Em Ruanda, no Quênia e em tantos outros lugares, os africanos foram submetidos a meticulosas classificações étnicas, que determinaram acessos diferenciados aos serviços e empregos públicos. A produção política da raça é um ato político que não demanda diferenças de cor da pele.

O racismo contamina profundamente as sociedades quando a lei sinaliza às pessoas que elas pertencem a determinado grupo racial - e que seus direitos são afetados por esse critério de pertinência de raça. Nos Estados Unidos, modelo por excelência das políticas de cotas raciais, a abolição da escravidão foi seguida pela produção de leis raciais baseadas na regra da "gota de sangue única". Essa regra, que é a negação da mestiçagem biológica e cultural, propiciou a divisão da sociedade em guetos legais, sociais, culturais e espaciais. De acordo com ela, as pessoas são, irrevogavelmente, "brancas" ou "negras". Eis aí a inspiração das leis de cotas raciais no Brasil.

"Eu tenho o sonho que meus quatro pequenos filhos viverão um dia numa nação na qual não serão julgados pela cor da sua pele mas pelo conteúdo de seu caráter”. Há 45 anos, em agosto, Martin Luther King abriu um horizonte alternativo para os norte-americanos, ancorando-o no "sonho americano" e no princípio político da igualdade de todos perante a lei, sobre o qual foi fundada a nação. Mas o desenvolvimento dessa visão pós-racial foi interrompido pelas políticas racialistas que, a pretexto de reparar injustiças, beberam na fonte envenenada da regra da "gota de sangue única". De lá para cá, como documenta extensamente Thomas Sowell em Ação afirmativa ao redor do mundo: um estudo empírico (Univer Cidade, 2005), as cotas raciais nos Estados Unidos não contribuíram em nada para reduzir desigualdades mas aprofundaram o cisma racial que marca como ferro em brasa a sociedade norte-americana.

"É um impasse racial no qual estamos presos há muitos anos", na constatação do senador Barack Obama, em seu discurso pronunciado a 18 de março, que retoma o fio perdido depois do assassinato de Martin Luther King. O "impasse" não será superado tão cedo, em virtude da lógica intrínseca das leis raciais. Como assinalou Sowell, com base em exemplos de inúmeros países, a distribuição de privilégios segundo critérios etno-raciais tende a retroalimentar as percepções racializadas da sociedade - e em torno dessas percepções articulam-se carreiras políticas e grupos organizados de pressão.

Mesmo assim, algo se move nos Estados Unidos. Há pouco, repercutindo um desencanto social bastante generalizado com o racialismo, a Suprema Corte declarou inconstitucionais as políticas educacionais baseadas na aplicação de rótulos raciais às pessoas. No seu argumento, o presidente da Corte, juiz John G. Roberts Jr., escreveu que "o caminho para acabar com a discriminação baseada na raça é acabar com a discriminação baseada na raça". Há um sentido claro na reiteração: a inversão do sinal da discriminação consagra a raça no domínio da lei, destruindo o princípio da cidadania.

Naquele julgamento, o juiz Anthony Kennedy alinhou-se com a maioria, mas proferiu um voto separado que contém o seguinte protesto: "Quem exatamente é branco e quem é não-branco? Ser forçado a viver sob um rótulo racial oficial é inconsistente com a 
dignidade dos indivíduos na nossa sociedade. E é um rótulo que um indivíduo é impotente para mudar!". Nos censos do IBGE, as informações de raça/cor abrigam a mestiçagem e recebem tratamento populacional. As leis raciais no Brasil são algo muito diferente: elas têm o propósito de colar "um rótulo que um indivíduo é impotente para mudar" e, no caso das cotas em concursos vestibulares, associam nominalmente cada jovem candidato a uma das duas categorias "raciais" polares, impondo-lhes uma irrecorrível identidade oficial.

O juiz Kennedy foi adiante e, reconhecendo a diferença entre a doutrina de ações afirmativas e as políticas de cotas raciais, sustentou a legalidade de iniciativas voltadas para a promoção ativa da igualdade que não distinguem os indivíduos segundo rótulos raciais. Reportando-se à realidade norte-americana da persistência dos guetos, ele mencionou, entre outras, a seleção de áreas residenciais racialmente segregadas para os investimentos prioritários em educação pública.

No Brasil, difunde-se a promessa sedutora de redução gratuita das desigualdades por meio de cotas raciais para ingresso nas universidades. Nada pode ser mais falso: as cotas raciais proporcionam privilégios a uma ínfima minoria de estudantes de classe média e conservam intacta, atrás de seu manto falsamente inclusivo, uma estrutura de ensino público arruinada. Há um programa inteiro de restauração da educação pública a se realizar, que exige políticas adequadas e vultosos investimentos. É preciso elevar o padrão geral do ensino mas, sobretudo, romper o abismo entre as escolas de qualidade, quase sempre situadas em bairros de classe média, e as escolas devastadas das periferias urbanas, das favelas e do meio rural. O direcionamento prioritário de novos recursos para esses espaços de pobreza beneficiaria jovens de baixa renda de todos os tons de pele - e, certamente, uma grande parcela daqueles que se declaram "pardos" e "pretos".

A meta nacional deveria ser proporcionar a todos um ensino básico de qualidade e oportunidades verdadeiras de acesso à universidade. Mas há iniciativas a serem adotadas, imediatamente, em favor de jovens de baixa renda de todas as cores que chegam aos umbrais do ensino superior, como a oferta de cursos preparatórios gratuitos e a eliminação das taxas de inscrição nos exames vestibulares das universidades públicas. Na Universidade Estadual Paulista (Unesp), o Programa de Cursinhos PréVestibulares Gratuitos, destinado a alunos egressos de escolas públicas, atendeu em 2007 a 3.714 jovens, dos quais 1.050 foram aprovados em concursos vestibulares, sendo 707 em universidades públicas. Medidas como essa, que não distinguem os indivíduos segundo critérios raciais abomináveis, têm endereço social certo e contribuem efetivamente para a amenização das desigualdades.

A sociedade brasileira não está livre da chaga do racismo, algo que é evidente no cotidiano das pessoas com tom de pele menos claro, em especial entre os jovens de baixa renda. A cor conta, ilegal e desgraçadamente, em incontáveis processos de admissão de funcionários. A discriminação se manifesta de múltiplas formas, como por exemplo na hora das incursões policiais em bairros periféricos ou nos padrões de aplicação de ilegais mandados de busca coletivos em áreas de favelas.

Por certo existe preconceito racial e racismo no Brasil, mas o Brasil não é uma nação racista. Depois da Abolição, no lugar da regra da "gota de sangue única", a nação brasileira elaborou uma identidade amparada na idéia anti-racista de mestiçagem e produziu leis que criminalizam o racismo. Há sete décadas, a República não conhece 
movimentos racistas organizados ou expressões significativa de ódio racial. O preconceito de raça, acuado, refugiou-se em expressões oblíquas envergonhadas, temendo assomar à superfície. A condição subterrânea do preconceito é um atestado de que há algo de muito positivo na identidade nacional brasileira, não uma prova de nosso fracasso histórico.

“Quem exatamente é branco e quem é não-branco?" - a indagação do juiz Kennedy provoca algum espanto nos Estados Unidos, onde quase todos imaginam conhecer a identidade "racial" de cada um, mas parece óbvia aos ouvidos dos brasileiros. Entre nós, casamentos interraciais não são incomuns e a segregação residencial é um fenômeno basicamente ligado à renda, não à cor da pele. Os brasileiros tendem a borrar as fronteiras "raciais", tanto na prática da mestiçagem quanto no imaginário da identidade, o que se verifica pelo substancial e progressivo incremento censitário dos "pardos", que saltaram de $21 \%$ no Censo de 1940 para $43 \%$ na PNAD de 2006, e pela paralela redução dos "brancos" (de 63\% para 49\%) ou "pretos" (de 15\% para 7\%).

A percepção da mestiçagem, que impregna profundamente os brasileiros, de certa forma reflete realidades comprovadas pelos estudos genéticos. Uma investigação já célebre sobre a ancestralidade de brasileiros classificados censitariamente como "brancos", conduzida por Sérgio Pena e sua equipe da Universidade Federal de Minas Gerais, comprovou cientificamente a extensão de nossas miscigenações. "Em resumo, estes estudos filogeográficos com brasileiros brancos revelaram que a imensa maioria das patrilinhagens é européia, enquanto a maioria das matrilinhagens (mais de 60\%) é ameríndia ou africana" (PENA, S. "Pode a genética definir quem deve se beneficiar das cotas universitárias e demais ações afirmativas?", Estudos Avançados 18 (50), 2004). Especificamente, a análise do DNA mitocondrial, que serve como marcador de ancestralidades maternas, mostrou que $33 \%$ das linhagens eram de origem ameríndia, $28 \%$ de origem africana e $39 \%$ de origem européia.

Os estudos de marcadores de DNA permitem concluir que, em 2000, existiam cerca de 28 milhões de afrodescendentes entre os 90,6 milhões de brasileiros que se declaravam "brancos" e que, entre os 76,4 milhões que se declaravam "pardos" ou "pretos", $20 \%$ não tinham ancestralidade africana. Não é preciso ir adiante para perceber que não é legítimo associar cores de pele a ancestralidades e que as operações de identificação de "negros" com descendentes de escravos e com "afrodescentes" são meros exercícios da imaginação ideológica. Do mesmo modo, a investigação genética evidencia a violência intelectual praticada pela unificação dos grupos censitários "pretos" e "pardos" num suposto grupo racial "negro".

Mas a violência não se circunscreve à esfera intelectual. As leis de cotas raciais são veículos de uma engenharia política de fabricação ou recriação de raças. Se, individualmente, elas produzem injustiças singulares, socialmente têm o poder de gerar "raças oficiais", por meio da divisão dos jovens estudantes em duas raças polares. Como, no Brasil, não sabemos quem exatamente é "negro" e quem é "não-negro", comissões de certificação racial estabelecidas pelas universidades se encarregam de traçar uma fronteira. A linha divisória só se consolida pela validação oficial da autodeclaração dos candidatos, num processo sinistro em que comissões universitárias investigam e deliberam sobre a "raça verdadeira" dos jovens a partir de exames de imagens fotográficas ou de entrevistas identitárias. No fim das contas, isso equivale ao 
cancelamento do princípio da autodeclaração e sua substituição pela atribuição oficial de identidades raciais.

$\mathrm{Na}$ UnB, uma comissão de certificação racial composta por professores e militantes do movimento negro chegou a separar dois irmãos gêmeos idênticos pela fronteira da raça. No Maranhão, produziram-se fenômenos semelhantes. Pelo Brasil afora, os mesmos candidatos foram certificados como "negros" em alguma universidade mas descartados como "brancos" em outra. A proliferação das leis de cotas raciais demanda a produção de uma classificação racial geral e uniforme. Esta é a lógica que conduziu o MEC a implantar declarações raciais nominais e obrigatórias no ato de matrícula de todos os alunos do ensino fundamental do país. O horizonte da trajetória de racialização promovida pelo Estado é o estabelecimento de um carimbo racial compulsório nos documentos de identidade de todos os brasileiros. A história está repleta de barbaridades inomináveis cometidas sobre a base de carimbos raciais oficialmente impostos.

A propaganda cerrada em favor das cotas raciais assegura-nos que os estudantes universitários cotistas exibem desempenho similar ao dos demais. Os dados concernentes ao tema são esparsos, contraditórios e pouco confiáveis. Mas isso é essencialmente irrelevante, pois a crítica informada dos sistemas de cotas nunca afirmou que estudantes cotistas seriam incapazes de acompanhar os cursos superiores ou que sua presença provocaria queda na qualidade das universidades. As cotas raciais não são um distúrbio no ensino superior, mas a face mais visível de uma racialização oficial das relações sociais que ameaça a coesão nacional.

A crença na raça é o artigo de fé do racismo. A fabricação de "raças oficiais" e a distribuição seletiva de privilégios segundo rótulos de raça inocula na circulação sanguínea da sociedade o veneno do racismo, com seu cortejo de rancores e ódios. No Brasil, representaria uma revisão radical de nossa identidade nacional e a renúncia à utopia possível da universalização da cidadania efetiva.

Ao julgar as cotas raciais, o STF não estará deliberando sobre um método de ingresso nas universidades, mas sobre o significado da nação e a natureza da Constituição. Leis raciais não ameaçam uma "elite branca", conforme esbravejam os racialistas, mas passam uma fronteira brutal no meio da maioria absoluta dos brasileiros. Essa linha divisória atravessaria as salas de aula das escolas públicas, os ônibus que conduzem as pessoas ao trabalho, as ruas e as casas dos bairros pobres. Neste início de terceiro milênio, um Estado racializado estaria dizendo aos cidadãos que a utopia da igualdade fracassou - e que, no seu lugar, o máximo que podemos almejar é uma trégua sempre provisória entre nações separadas pelo precipício intransponível das identidades raciais. É esse mesmo o futuro que queremos?

Adel Daher - Diretor do Sindicato dos Ferroviários de Bauru e MS

Adelaide Jóia - Socióloga e Mestre em Educação Infantil pela Pontifícia Universidade Católica de São Paulo (PUC-SP)

Adriana Atila - Doutora em Antropologia Cultural, IFCS, Universidade Federal do Rio de Janeiro (UFRJ)

Aguinaldo Silva - Jornalista, telenovelista

Alba Zaluar - Titular de Antropologia da Universidade do Estado do Rio de Janeiro

(UERJ), Livre-docente da Universidade Estadual de Campinas (UNICAMP), colunista 
da Folha de S. Paulo

Almir Lima da Silva - Jornalista, Centro de Cultura Negra de Macaé-RJ

Alzira Alves de Abreu - Pesquisadora do CPDOC da Fundação Getulio Vargas

Amâncio Paulino de Carvalho - Professor da Faculdade de Medicina Universidade

Federal do Rio de Janeiro (UFRJ)

Ana Maria Machado - Escritora, membro da Academia Brasileira de Letras

Ana Teresa A. Venancio - Pesquisadora da Casa de Oswaldo Cruz/Fiocruz

Ângela Porto - Pesquisadora Titular, Fundação Oswaldo Cruz

Antonio Cicero - Poeta e ensaísta

Antonio Risério - Antropólogo

Arlindo Belo da Silva - Conselheiro Fiscal da Confederação Nacional dos

Trabalhadores do Ramo Químico (CNQ-CUT)

Bernardo Lewgoy - Professor Adjunto do Departamento de Antropologia da

Universidade Federal do Rio Grande do Sul (UFRGS)

Bernardo Sorj - Professor Titular da Universidade Federal do Rio de Janeiro (UFRJ)

Bernardo Vilhena - Poeta

Bila Sorj - Professora Titular da Universidade Federal do Rio de Janeiro (UFRJ)

Bolivar Lamounier - Cientista Político

Caetano Veloso - cantor e compositor

Carlos A. de L. Costa Ribeiro - Professor e Consultor em Ciências do Meio Ambiente

Carlos Pio - Professor da Universidade de Brasília (UNB)

Carlos José Serapião - Professor Titular aposentado da Faculdade de Medicina da

Universidade Federal do Rio de Janeiro (UFRJ) e Professor Titular da Universidade da

Região de Joinville-SC

Celso Castro - Antropólogo, professor do CPDOC da Fundação Getulio Vargas

César Benjamin - Editor

Charles Pires - Diretor do Sindicato dos Funcionários Publicos Municipais de

Florianópolis e membro da Executiva da CUT-SC

Cremilda Medina - Jornalista e professora Titular da Universidade de São Paulo (USP)

Cynthia Maria Pinto da Luz - Advogada, Conselheira Nacional do Movimento

Nacional em Defesa dos Direitos Humanos

Claudia Travassos - Pesquisadora Titular, Fundação Oswaldo Cruz

Darcy Fontoura de Almeida - Professor Emérito da Universidade Federal do Rio de

Janeiro (UFRJ)

Demétrio Magnoli - Sociólogo, integrante do Grupo de Análises de Conjuntura

Internacional (Gacint) da Universidade de São Paulo (USP)

Diomédes Matias da Silva Filho - Diretor do Sindicato dos Professores do Estado de

Pernambuco

Domingos Guimaraens - Poeta e artista plástico

Edmar Lisboa Bacha - Economista

Eduardo Giannetti - Economista

Eduardo Pizarro Carnelós - Advogado, ex-presidente da Associação dos Advogados de

São Paulo e do Conselho Nacional de Política Criminal e Penitenciária do Ministério da Justiça

Elizabeth Balbachevsky - Professora Associada do Departamento de Ciência Política e pesquisadora sênior do Núcleo de Pesquisa de Políticas Públicas da Universidade de São Paulo (USP)

Esteffane Emanuelle Ferreira - Estudante, Coordenação do DCE da Universidade

Federal de Mato Grosso (UFMT) 
Eunice Durham - Professora Emérita da FFLCH da Universidade de São Paulo (USP)

Fernando Gomes Martins - Associação de Moradores do Parque Bandeirantes e

Movimento Hip Hop Sumaré-SP

Ferreira Gullar - Poeta

Flávio Rabelo Versiani - Professor Titular do Departamento de Economia da

Universidade de Brasília (UNB)

Francisco João Lessa - Advogado, Direção do PT-SC

Francisco Johny Rodrigues Silva - Coordenador do Fórum Afro da Amazônia (FORAFRO)

Francisco Martinho - Professor do Departamento de História da Universidade do

Estado do Rio de Janeiro (UERJ)

Francisco Mauro Salzano - Professor Emérito do Departamento de Genética da

Universidade Federal do Rio Grande do Sul (UFRGS)

George de Cerqueira Leite Zarur - Professor Internacional da Faculdade Latino

Americana de Ciências Sociais (FLACSO)

Gerald Thomas - Dramaturgo, criador e diretor da Companhia de Ópera Seca

Gilberto Horchman - Pesquisador, Fundação Oswaldo Cruz

Gilberto Velho - Professor Titular de Antropologia do Museu Nacional da Universidade

Federal do Rio de Janeiro (UFRJ) e membro da Academia Brasileira de Ciências

Gilda Portugal - Professora de Sociologia da Universidade Estadual de Campinas

(UNICAMP)

Gilson Schwartz - Professor da Escola de Comunicações e Artes da Universidade de

São Paulo (USP) e coordenador da Cidade do Conhecimento

Glaucia Kruse Villas Bôas - Professora Associada de Sociologia do Instituto de

Filosofia e Ciências Sociais da Universidade Federal do Rio de Janeiro (UFRJ)

Gursen De Miranda - Professor Adjunto da Universidade Federal de Roraima (UFRR) e

Presidente da Academia Brasileira de Letras Agrárias

Helda Castro de Sá - Coordenadora da Associação dos Caboclos e Ribeirinhos da

Amazônia

Helena Severo - Cientista social, pesquisadora do Núcleo de Estudos e Pesquisas (NEP)

do Tribunal de Contas do Rio de Janeiro

Helga Hoffmann - Economista, integrante do Grupo de Análises de Conjuntura

Internacional (Gacint) da Universidade de São Paulo (USP)

Heloisa Helena T. de Souza Martins - Professora aposentada de Sociologia da

Universidade de São Paulo (USP)

Isabel Lustosa - Pesquisadora Titular da Fundação Casa de Rui Barbosa

João Rodarte - Empresário

João Ubaldo Ribeiro - Escritor

José Álvaro Moisés - Professor Titular do Departamento de Ciência Política e Diretor do Núcleo de Pesquisa de Políticas Públicas da Universidade de São Paulo (USP)

José Arbex Jr. - Jornalista e professor do Departamento de Jornalismo da Pontifícia

Universidade Católica de São Paulo (PUC-SP)

José Augusto Guilhon Albuquerque - Professor Titular (aposentado) de Relações

Internacionais da Faculdade de Economia e Administração da Universidade de São

Paulo (USP)

José Carlos Miranda - Coordenador Nacional do Movimento Negro Socialista

José Goldemberg - Ex-reitor da Universidade de São Paulo (USP)

José de Souza Martins - Professor Titular (aposentado) de Sociologia da Universidade de São Paulo (USP) 
José Roberto Pinto de Góes - Historiador e professor da Universidade do Estado do Rio de Janeiro (UERJ)

Karina Kuschnir - Antropóloga, professora da Universidade Federal do Rio de Janeiro (UFRJ)

Leão Alves - Presidente do Movimento Pardo-Mestiço Brasileiro

Leonel Munhoz Coimbra - Analista de Controle Externo, Especialista em Políticas

Públicas e Gestão Governamental da Escola Nacional de Administração Pública

Lourdes Sola - Presidente da Associação Internacional de Ciência Política e professora

aposentada da Universidade de São Paulo (USP)

Luciana Villas-Boas - Diretora do Grupo Editorial Record

Luciene G. Souza - Mestre em Saúde Pública, Fundação Nacional de Saúde

Luiz Alphonsus - Artista Plástico

Luiz Fernando Dias Duarte - Professor Associado do Museu Nacional da Universidade

Federal do Rio de Janeiro (UFRJ)

Luiz Werneck Vianna - Professor Titular do Instituto Universitário de Pesquisas do Rio de Janeiro (IUPERJ)

Lya Luft - Escritora

Manolo Garcia Florentino - Professor do Departamento de Historia da Universidade

Federal do Rio de Janeiro (UFRJ)

Marcelo Hermes-Lima - Professor de Bioquímica Médica da Universidade de Brasília

(UNB)

Marcos Chor Maio - Pesquisador da da Casa de Oswaldo Cruz/Fiocruz

Margarida Cintra Gordinho - Editora

Maria Alice Resende de Carvalho - Socióloga

Maria Cátira Bortolini - Professora da Universidade Federal do Rio Grande do Sul

(UFRGS)

Maria Conceição Pinto de Góes - Professora do Programa de Pós-Graduação em

História Comparada da Universidade Federal do Rio de Janeiro (UFRJ)

Maria Herminia Tavares de Almeida - Cientista Política

Maria Laura Viveiros de Castro Cavalcanti - Professora Associada do Instituto de

Filosofia e Ciencias Sociais da Universidade Federal do Rio de Janeiro (UFRJ)

Maria Sylvia Carvalho Franco - Professora Titular da Universidade de São Paulo (USP)

e da Universidade Estadual de Campinas (UNICAMP)

Mariza Peirano - Professora Titular, Antropologia, Universidade de Brasília (UNB)

Maurício Soares Leite - Professor Adjunto, Departamento de Nutrição da Universidade

Federal de Santa Catarina (UFSC)

Moacyr Góes - Diretor de teatro e cineasta

Monica Grin - Professora da Universidade Federal do Rio de Janeiro (UFRJ)

Nelson Motta - Produtor musical, jornalista e escritor

Patrícia Vanzella - Professora Adjunta, Departamento de Música da Universidade de

Brasília (UNB)

Pedro Paulo Poppovic - Empresário

Peter Henry Fry - Professor Titular da Universidade Federal do Rio de Janeiro (UFRJ)

Reinaldo Azevedo - Jornalista, articulista da revista VEJA e editor do "Blog do

Reinaldo Azevedo"

Renata Aparecida Vaz - Coordenação do Movimento Negro Socialista-SP

Renato Lessa - Professor Titular de Teoria Política do Instituto Universitário de

Pesquisas do Rio de Janeiro (IUPERJ) e da Universidade Federal Fluminense (UFF),

Presidente do Instituto Ciência Hoje 
Ricardo Ventura Santos - Pesquisador titular da Escola Nacional de Saúde Pública da Fundação Oswaldo Cruz e Professor Adjunto do Museu Nacional da Universidade Federal do Rio de Janeiro (UFRJ)

Roberta Fragoso Menezes Kaufmann - Procuradora do Distrito Federal, Mestre em Direito pela Universidade de Brasília (UNB) e Professora de Direito Constitucional Roberto Romano da Silva - Professor Titular da Universidade Estadual de Campinas (UNICAMP)

Rodolfo Hoffmann - Professor do Instituto de Economia da Universidade Estadual de Campinas (UNICAMP)

Ronaldo Vainfas - Professor Titular da Universidade Federal Fluminense (UFF)

Roque Ferreira - Coordenação da Federação Nacional de Trabalhadores de Transporte sobre Trilho-CUT

Ruth Correa Leite Cardoso - Antropóloga

Serge Goulart - Secretário da Esquerda Marxista do PT

Sergio Danilo Pena - Professor Titular do Departamento de Bioquímica e Imunologia

da Universidade Federal de Minas Gerais (UFMG) e membro titular da Academia

Brasileira de Ciências

Simon Schwartzman - Pesquisador do Instituto de Estudos do Tabalho e Sociedade (IETS)

Simone Monteiro - Pesquisadora Associada, Fundação Oswaldo Cruz

Wanderley Guilherme dos Santos - Cientista Político

Wilson Trajano Filho - Professor do Departamento de Antropologia da Universidade de Brasília (UNB)

Yvonne Maggie - Professora Titular da Universidade Federal do Rio de Janeiro (UFRJ) 


\section{ANEXO 5 \\ Anexo 5 - Manifesto a favor das Cotas \\ MANIFESTO EM FAVOR DA LEI DE COTAS E DO ESTATUTO DA IGUALDADE RACIAL}

\section{AOS/AS DEPUTADOS/AS E SENADORES/AS DO CONGRESSO BRASILEIRO}

A desigualdade racial no Brasil tem fortes raízes históricas e esta realidade não será alterada significativamente sem a aplicação de políticas públicas específicas. A Constituição de 1891 facilitou a reprodução do racismo ao decretar uma igualdade puramente formal entre todos os cidadãos. A população negra acabava de ser colocada em uma situação de completa exclusão em termos de acesso à terra, à instrução e ao mercado de trabalho para competir com os brancos diante de uma nova realidade econômica que se instalava no país. Enquanto se dizia que todos eram iguais na letra da lei, várias políticas de incentivo e apoio diferenciado, que hoje podem ser lidas como ações afirmativas, foram aplicadas para estimular a imigração de europeus para o Brasil.

Esse mesmo racismo estatal foi reproduzido e intensificado na sociedade brasileira ao longo de todo o século vinte. Uma série de dados oficiais sistematizados pelo IPEA no ano 2001 resume o padrão brasileiro de desigualdade racial: por 4 gerações ininterruptas, pretos e pardos têm contado com menos escolaridade, menos salário, menos acesso à saúde, menor índice de emprego, piores condições de moradia, quando contrastados com os brancos e asiáticos. Estudos desenvolvidos nos últimos anos por outros organismos estatais demonstram claramente que a ascensão social e econômica no país passa necessariamente pelo acesso ao ensino superior.

Foi a constatação da extrema exclusão dos jovens negros e indígenas das universidades que impulsionou a atual luta nacional pelas cotas, cujo marco foi a Marcha Zumbi dos Palmares pela Vida, em 20 de novembro de 1995, encampada por uma ampla frente de solidariedade entre acadêmicos negros e brancos, coletivos de estudantes negros, cursinhos pré-vestibulares para afrodescendentes e pobres e movimentos negros da sociedade civil, estudantes e líderes indígenas, além de outros setores solidários, como jornalistas, líderes religiosos e figuras políticas --boa parte dos quais subscreve o presente documento. A justiça e o imperativo moral dessa causa encontraram ressonância nos últimos governos, o que resultou em políticas públicas concretas, dentre elas: a criação do Grupo de Trabalho Interministerial para a Valorização da População Negra, de 1995; as primeiras ações afirmativas no âmbito dos Ministérios, em 2001; a criação da Secretaria Especial para Promoção de Políticas da Igualdade Racial (SEPPIR), em 2003; e, finalmente, a proposta dos atuais Projetos de Lei que estabelecem cotas para estudantes negros oriundos da escola pública em todas as universidades federais brasileiras, e o Estatuto da Igualdade Racial.

O PL 73/99 (ou Lei de Cotas) deve ser compreendido como uma resposta coerente e responsável do Estado brasileiro aos vários instrumentos jurídicos internacionais a que aderiu, tais como a Convenção da ONU para a Eliminação de 
Todas as Formas de Discriminação Racial (CERD), de 1969, e, mais recentemente, ao Plano de Ação de Durban, resultante da III Conferência Mundial de Combate ao Racismo, Discriminação Racial, Xenofobia e Intolerância Correlata, ocorrida em Durban, na África do Sul, em 2001. O Plano de Ação de Durban corrobora a ênfase, já colocada pela CERD, de adoção de ações afirmativas como um mecanismo importante na construção da igualdade racial, uma vez aqui que as ações afirmativas para minorias étnicas e raciais já se efetivam em inúmeros países multiétnicos e multi-raciais semelhantes ao Brasil. Foram incluídas na Constituição da Índia, em 1949; adotadas pelo Estado da Malásia desde 1968; nos Estados Unidos desde 1972; na África do Sul, em 1994; e desde então no Canadá, na Austrália, na Nova Zelândia, na Colômbia e no México. Existe uma forte expectativa internacional de que o Estado brasileiro finalmente implemente políticas consistentes de ações afirmativas, inclusive porque o país conta com a segunda maior população negra do planeta e deve reparar as assimetrias promovidas pela intervenção do Estado da Primeira República com leis que outorgaram benefícios especiais aos europeus recém chegados, negando explicitamente os mesmos benefícios à população afrobrasileira.

Colocando o sistema acadêmico brasileiro em uma perspectiva internacional, concluímos que nosso quadro de exclusão racial no ensino superior é um dos mais extremos do mundo. Para se ter uma idéia da desigualdade racial brasileira, lembremos que, mesmo nos dias do apartheid, os negros da África do Sul contavam com uma escolaridade média maior que a dos negros no Brasil no ano 2000; a porcentagem de professores negros nas universidades sul-africanas, ainda na época do apartheid, era bem maior que a porcentagem dos professores negros nas nossas universidades públicas nos dias atuais. A porcentagem média de docentes nas universidades públicas brasileiras não chega a $1 \%$, em um país onde os negros conformam 45,6 \% do total da população. Se os Deputados e Senadores, no seu papel de traduzir as demandas da sociedade brasileira em políticas de Estado não intervierem aprovando o PL 73/99 e o Estatuto, os mecanismos de exclusão racial embutidos no suposto universalismo do estado republicano provavelmente nos levarão a atravessar todo o século XXI como um dos sistemas universitários mais segregados étnica e racialmente do planeta! E, pior ainda, estaremos condenando mais uma geração inteira de secundaristas negros a ficar fora das universidades, pois, segundo estudos do IPEA, serão necessários 30 anos para que a população negra alcance a escolaridade média dos brancos de hoje, caso nenhuma política específica de promoção da igualdade racial na educação seja adotada. Para que nossas universidades públicas cumpram verdadeiramente sua função republicana e social em uma sociedade multi-étnica e multi-racial, deverão algum dia refletir as porcentagens de brancos, negros e indígenas do país em todos os graus da hierarquia acadêmica: na graduação, no mestrado, no doutorado, na carreira de docente e na carreira de pesquisador.

No caminho da construção dessa igualdade étnica e racial, somente nos últimos 4 anos, mais de 30 universidades e Instituições de Ensino Superior públicas, entre federais e estaduais, já implementaram cotas para estudantes negros, indígenas e alunos da rede pública nos seus vestibulares e a maioria adotou essa medida após debates no interior dos seus espaços acadêmicos. Outras 15 instituições públicas estão prestes a adotar políticas semelhantes. Todos os estudos 
de que dispomos já nos permitem afirmar com segurança que o rendimento acadêmico dos cotistas é, em geral, igual ou superior ao rendimento dos alunos que entraram pelo sistema universal. Esse dado é importante porque desmonta um preconceito muito difundido de que as cotas conduziriam a um rebaixamento da qualidade acadêmica das universidades. Isso simplesmente não se confirmou! Uma vez tida a oportunidade de acesso diferenciado (e insistimos que se trata de cotas de entrada e não de saída), o rendimento dos estudantes negros não se distingue do rendimento dos estudantes brancos.

Outro argumento muito comum usado por aqueles que são contra as políticas de inclusão de estudantes negros por intermédio de cotas é que haveria um acirramento dos conflitos raciais nas universidades. Muito distante desse panorama alarmista, os casos de racismo que têm surgido após a implementação das cotas têm sido enfrentados e resolvidos no interior das comunidades acadêmicas, em geral com transparência e eficácia maiores do que havia antes das cotas. Nesse sentido, a prática das cotas tem contribuído para combater o clima de impunidade diante da discriminação racial no meio universitário. Mais ainda, as múltiplas experiências de cotas em andamento nos últimos 4 anos contribuíram para a formação de uma rede de especialistas e de uma base de dados acumulada que facilitará a implementação, a nível nacional, da Lei de Cotas.

Para que tenhamos uma noção da escala de abrangência dessas leis a serem votadas o PL 73/99, que reserva vagas na graduação, é uma medida ainda tímida: garantirá uma média nacional mínima de $22,5 \%$ de vagas nas universidades públicas para um grupo humano que representa $45,6 \%$ da população nacional. É preciso, porém, ter clareza do que significam esses $22,5 \%$ de cotas no contexto total do ensino de graduação no Brasil. Tomando como base os dados oficiais do INEP, o número de ingressos nas universidades federais em 2004 foi de 123.000 estudantes, enquanto o total de ingressos em todas as universidades (federais, estaduais, municipais e privadas) foi de 1.304 .000 estudantes. Se já tivessem existido cotas em todas as universidades federais para esse ano, os estudantes negros contariam com uma reserva de 27.675 vagas (22,5\% de 123.000 vagas). Em suma, a Lei de Cotas incidiria em apenas $2 \%$ do total de ingressos no ensino superior brasileiro. Devemos concluir que a desigualdade racial continuará sendo a marca do nosso universo acadêmico durante décadas, mesmo com a implementação do PL 73/99. Sem as cotas, porém, já teremos que começar a calcular em séculos a perspectiva de combate ao nosso racismo universitário. Temos esperança de que nossos congressistas aumentem esses índices tão baixos de inclusão!

Se a Lei de Cotas visa nivelar o acesso às vagas de ingresso nas universidades públicas entre brancos e negros, o Estatuto da Igualdade Racial complementa esse movimento por justiça. Garante o acesso mínimo dos negros aos cargos públicos e assegura um mínimo de igualdade racial no mercado de trabalho e no usufruto dos serviços públicos de saúde e moradia, entre outros. Nesse sentido, - Estatuto recupera uma medida de igualdade que deveria ter sido incluída na Constituição de 1891, no momento inicial da construção da República no Brasil. Foi sua ausência que aprofundou o fosso da desigualdade racial e da impunidade do racismo contra a população negra ao longo de todo o século XX. Por outro lado, 0 Estatuto transforma em ação concreta os valores de igualdade plasmados na 
Constituição de 1988, claramente pró-ativa na sua afirmação de que é necessário adotar mecanismos capazes de viabilizar a igualdade almejada. Enquanto o Estatuto não for aprovado, continuaremos reproduzindo o ciclo de desigualdade racial profunda que tem sido a marca de nossa história republicana até os dias de hoje.

Gostaríamos ainda de fazer uma breve menção ao documento contrário à Lei de Cotas e ao Estatuto da Igualdade Racial, enviado recentemente aos nobres parlamentares por um grupo de acadêmicos pertencentes a várias instituições de elite do país. Ao mesmo tempo em que rejeitam frontalmente as duas Leis em discussão, os assinantes do documento não apresentam nenhuma proposta alternativa concreta de inclusão racial no Brasil, reiterando apenas que somos todos iguais perante a lei e que é preciso melhorar os serviços públicos até atenderem por igual a todos os segmentos da sociedade. Essa declaração de princípios universalistas, feita por membros da elite de uma sociedade multi-étnica e multiracial com uma história recente de escravismo e genocídio sistemático, parece uma reedição, no século XXI, do imobilismo subjacente à Constituição da República de 1891: zerou, num toque de mágica, as desigualdades causadas por séculos de exclusão e racismo, e jogou para um futuro incerto o dia em que negros e índios poderão ter acesso eqüitativo à educação, às riquezas, aos bens e aos serviços acumulados pelo Estado brasileiro. Essa postergação consciente não é convincente. Diante dos dados oficiais recentes do IBGE e do IPEA que expressam, sem nenhuma dúvida, a nossa dívida histórica com os negros e os índios, ou adotamos cotas e implementamos o Estatuto, ou seremos coniventes com a perpetuação da nossa desigualdade étnica e racial.

Acreditamos que a igualdade universal dentro da República não é um princípio vazio e sim uma meta a ser alcançada. As ações afirmativas, baseadas na discriminação positiva daqueles lesados por processos históricos, são a figura jurídica criada pelas Nações Unidas para alcançar essa meta.

Conclamamos, portanto, os nossos ilustres congressistas a que aprovem, com a máxima urgência, a Lei de Cotas (PL73/1999) e o Estatuto da lgualdade Racial (PL 3.198/2000).

\section{Brasília, 3 de julho de 2006}

\section{Subscrevem este manifesto:}

1. Alexandre do Nascimento - Membro da Coordenação do Movimento PréVestibular para Negros e Carentes (PVNC), Professor da FAETEC e Editor da Revista Global Brasil.

2. Frei David Raimundo dos Santos - Diretor Executivo da EDUCAFRO rede de 255 prévestibulares comunitários para afrodescendentes e carentes.

3. José Jorge de Carvalho - Professor de Antropologia da Universidade de Brasília Pesquisador 1-A do CNPq - Propositor do Sistema de Cotas da UnB.

4. Abdias do Nascimento - IPEAFRO.

5. Adelaide Gonçalves - Professor da Universidade Federal do Ceará.

6. Adelia Miglievich - Professora da Universidade Estadual do Norte Fluminense UENF 
7. Adriana Pereira Campos - Professora de História da UFES, Doutora em História Social.

8. Ahyas Siss - Professor da Universidade Federal Rural do Rio de Janeiro.

9. Aldenir Dida Dias dos Santos - Professora de sociologia da Faculdade do Guarujá.

10. Alecsara Maciel - Professora do departamento de Ciências Sociais da Universidade Federal do Amapá (UNIFAP).

11. Alejandra Paschoal - Professora de Direito da Universidade de Brasília (UNB).

12. Alessandra Carvalho - Professora do Colégio de Aplicação da UFRJ

13. Alexandre Brasil Carvalho da Fonseca - Professor de Sociologia da Ciência da Universidade Federal do Rio de Janeiro. Membro do Conselho Nacional de Juventude.

14. Alexandre Fortes - Professor da Universidade Federal Rural do Rio de Janeiro.

15. Allan Müller Schroeder - Acadêmico do curso de Administração de Serviços Públicos da Universidade do Estado de Santa Catarina (UDESC) e do curso de direito da Universidade do Vale do Itajaí (UNIVALI).

16. Almires Machado Guarani - Advogado do Instituto Amigos do Índio, de Mato Grosso do Sul.

17. Álvaro Fernandes Sampaio - Tukano - Líder do Povo Tukano/ Assessor do Instituto Brasileiro da Propriedade Intelectual (INBRAPI).

18. Álvaro Roberto Pires - Professor da Universidade Federal do Maranhão (UFMA) - Diretor Depto.de Pós-Graduação (DPG/UFMA).

19. Alzira Rufino - Presidente da Casa de Cultura da Mulher Negra. Editora da revista Eparrei.

20. Amauri Mendes Pereira - Pesquisador Associado do Centro de Estudos AfroAsiático (CEAA) da Universidade Cândido Mendes.

21. Amaury Fernandes da Silva Junior - Professor da Escola de Comunicação da UFRJ.

22. Amilton Sá Barreto - Coordenador do Núcleo de Educação para a Igualdade Racial da Secretaria de Educação do Pará.

23. Ana Beatriz Souza Gomes - Professora de Educação da Universidade Federal do Piauí (UFPI).

24. Ana Claudia Duarte Rocha Marques - Professora de Antropologia da Universidade de São Paulo.

25. Ana Darc Martins de Azevedo - Professora da Universidade do Estado do Pará.

26. Ana Lucia Lopes - Coordenadora do Núcleo de Educação do Museu Afro Brasil.

27. Ana Lúcia Pereira - Pró-Reitora de Extensão da Universidade Federal do Tocantins - UFT.

28. Ana Lucia Valente - Professora de Extensão Rural da Faculadade de Agronomia e Medicina Veterinária da Universidade de Brasília.

29. Ana Maria Felippe - Coordenadora da Memória Lélia Gonzalez.

30. Ana Paula Ferraz - Pedagoga e Professora da rede pública do Rio de Janeiro.

31. André Augusto Brandão - Professor Adjunto da UFF, Programa de Estudos Pósgraduados em Política Social (ESS/UFF).

32. André Borges - Vice-Presidente e Coordenador de Direitos Humanos do Instituto Palmares de Direitos Humanos/RJ.

33. André Leonardo Chevitarese- Professor da Universidade Federal do Rio de Janeiro. 
34. André Martins - Professor de Metodologia, Filosofia e Psicanalise da Faculdade de Medicina da UFRJ.

35. Andreas Hofbauer - Professor de Antropologia da Universidade Estadual de Sãi Paulo (UNESP) de Marília.

36. Angela Maria de Oliveria Almeida - Professora do Instituto de Psicologia da UNB 37. Angela Maria dos Santos - Professora. Substituta da Universidade Federal do Mato Grosso (UFMT). Pesquisadora do NEPRE/UFMT.

38. Angela Renata Gonçalves Castilho de Azevedo - Professora de História da FAETEC.

39. Angelica Basthi - Jornalista. Membro da coordenação da Comissão de Jornalistas pela Igualdade Racial (Cojira-Rio).

40. Anne de Matos Souza - Pesquisadora do Núcleo de Pesquisas em Relações Raciais e Educação (NEPRE) da Universidade Federal do Mato Grosso.

41. Antônio Eustáquio de Moura -Pprofessor da Universidade do Estado de Mato Grosso- UNEMAT

42. Antonio Grassi - ator e Presidente da Funarte

43. Antonio Luigi Negro - Professor de História da Universidade Federal da Bahia

44. Antonio Santana (Pastor) - Professor de Teologia da Universidade Metodista de São Bernanrdo do Campo (UMESB).

45. Antonio Sérgio Alfredo Guimarães - Professor do Departamento de Sociologia da USP

46. Apolinário Alves Moreira - Auditor da Universidade Federal do Pará.

47. Arivaldo Lima Alves - Professor de Antropologia da Universidade Estadual da Bahia.

48. Armando Mecenas de Oliveira - Centro Cultural Araçá - São Mateus, ES.

49. Arthur Leandro - Artista, Professor da Escola de Artes Visuais e Designer da UFPA, Tàta Kissikarimgomba do Mansu Nangetu - Belém/PA.

50. Augusto Boal - Artista, Professor e Diretor Artístico do Centro de Teatro do Oprimido - CTO/RJ.

51. Bárbara Santos - Coordenadora do Centro de Teatro do Oprimido - CTO-Rio.

52. Betania Suzuki - Membro da coordenação do Curso Pré-Vestibular para Pessoas Economicamente Carentes, Negros e Praticantes de Cultos Afro da Universidade Federal do Amapá.

53. Bruna Franchetto - Professora de Lingüística do Museu Nacional, UFRJ. Pesquisadora do CNPq.

54. Caetana Damasceno - Professora de Antropologia da Universidade Federal Rural do Rio de Janeiro.

55. Cândido Grzybowski - Diretor do lbase

56. Carla Ramos - Ex-aluna do PVNC, Mestre em Sociologia e Antropologia peloPPGSAUFRJ e pesquisadora do Centro Nacional de Folclore e Cultura Popular/ IPHAN.

57. Carlos Benedito Rodrigues da Silva - Professor do Programa de Pós Graduação em Ciências Sociais da Universidade Federal do Maranhão- Coordenador do NEAB/UFMA - Conselheiro Consultivo do Centro do Cultura Negra do Maranhão.

58. Carlos Fausto - Professor de Antropologia do Museu Nacional da UFRJ/Pesquisador do CNPq.

59. Carlos Frederico Leão Rocha - Professor do Instituto de Economia da UFRJ.

60. Carlos Hasenbalg - Professor Titular do IUPERJ - aposentado

61. Carlos Nobre - Professor do Departamento de Comunicação Social da PUC-Rio. 
62. Carmen Junqueira - Professora Titular de Antropologia da PUC-SP.

63. Cecilia MacDowell Santos - Professora de Sociologia da University of San Francisco, USA

64. Celeste Maria Libania dos Santos - Sócia-propietária da Sobá Livros e Cd's Ltda.

65. Celso Ribeiro de Almeida - Professor do Instituto de Biologia da UNICAMP.

66. Clair Castilhos Coelho - Professora do Departamento de Saúde Pública da Universidade Federal de Santa Catarina

67. Claudia de Andrade Melim-McLeod - Programa das Nações Unidas para o Desenvolvimento (PNUD).

68. Claudia Ferreira - Jornalista. Coordenadora do Centro de Atividade Culturais, Econômicas e Sociais (CACES).

69. Cláudio Henrique Pedrosa - Rede de Homens pela Equidade de Gênerol.

70. Cleber José Carminati - Professor de Comunicação Social Universidade Federal do Espírito Santo

71. Clever Alves Machado - Conselheiro do Conselho Estadual de Participação e Integração da Comunidade Negra - CCN/MG.

72. Cleyton Wenceslau Borges - Assessor de Cidadania ePolíticas Públicas da Sede da Educafro.

73. Climene Laura de Camargo - Professora da Escola de Enfermagem da Universidade Federal da Bahia (UFBA).

74. CPV-Negros da Universidade Federal do Amapá - UNIFAP.

75. Cristina Lavrador - Professora da Universidade Federal do Espírito Santo.

76. Daisy Macedo de Barcellos - Doutora em Antropologia social (aposentada UFRGS).

77. Damião dos Reis - Capitão-Regente da Guarda do Congo Velho do Rosário de Belo Horizonte.

78. Daniel Aarão Reis - Professor Titular de História Contemporânea, Universidade Federal Fluminense.

79. Daniel Lins - Filósofo, sociólogo e psicanalista. Professor da Universidade Federal do Ceará. Coordenador do Laboratório de Estudos e Pesquisas da Subjetividade (LEPSUFC).

80. Daniel Munduruku - Liderança Indígena e Presidente do INBRAPI - São Paulo.

81. Daniela Sanches Frozi - Doutoranda de Nutrição da Universidade Federal do Rio de Janeiro e Professora substituta do Departamento de Nutrição Social Aplicada da UFRJ.

82. Débora Diniz Rodrigues - Professora de Serviço Social e Bioética da Universidade de Brasília (UNB).

83. Deise Benedito - Presidente da Fala Preta Organização de Mulheres Negras / Fórum Nacional de Mulheres Negras.

84. Delcele Queiroz - Professora da Universidade Estadual da Bahia.

85. Demartone Gomes - Coordenador da Regional 5 do Sindicato Estadual de Profissionais da Educação (SEPE-RJ).

86. Denise Fagundes Jardim - Professora do departamento de antropologia da UFRGS.

87. Diórgenes Pacheco de Lima - Professor do Curso Pré-Vestibular Popular Resgate de Porto Alegre-RS.

88. Dojival Vieira dos Santos - Jornalista, Editor da Agência Afroétnica de Notícias Afropress (www.afropress.com). 
89. Dora Lúcia Lima Bertúlio - Procuradora da Universidade Federal do Paraná (UFPR) - Propositora do Sistema de Cotas da UFPR.

90. Dulcilene Santiago de Souza. Assitente Social. Núcleo Santa Cruz/Guarujá.

91. Edilene Machado Pereira- Professora do Centro Universitário da Bahia e mestranda em Ciências Sociais da PUC-SP.

92. Edna Roland - Relatora Geral da III Conferência Mundial contra o Racismo, Discriminação Racial, Xenofobia e Intolerância Correlata, de Durban, África do Sul.

93. Edson Alves de Souza Filho - Professor da Faculdade de Educação da UFRJ.

94. Edson Borges: Professor de Antropologia e História da África da Universidade Candido Mendes

95. Eduardo Rosa - Presidente da Comunidade de Resgate Afro Rosas Negra

96. Eduardo Viveiros de Castro - Professor de Antropologia do Museu Nacional da

UFRJ/Pesquisador 1-A do CNPq.

97. Elane Carneiro de Albuquerque - Instituto Negra do Ceará - INEGRA.

98. Eliane Hojaij Gouveia - Professora Doutora de Antropologia da PUC-SP.

99. Eliane Pinto de Carvalho - Diretora da Escola Municipal Fernando Rodrigues da Silveira / Rio de Janeiro.

100. Elisa Larkin Nascimento - Diretora do IPEAFRO.

101. Emir Sader - Professor da UERJ/Presidente do Laboratório de Políticas Públicas (LPP) da UERJ.

102. Eniuza Pereira Garcia - Coordenadora do Pré-Vestibular Zumbi dos Palmares, Porto Alegre, RS.

103. Erasto Fortes Mendonça - Professor da Faculdade de Educação da Universidade de Brásília

104. Erica Simone Almeida Resende - Cientista Política e Pesquisadora do NUPRI (Núcleo de Pesquisa em Relações Internacionais) - USP.

105. Erisvaldo Pereira dos Santos - Professor Adunto da Universidade Federal de Ouro Preto - UFOP.

106. Eurípedes Antônio Funes - Professor da Universidade Federal do Ceará.

107. Fabiana Oliveira - Membro da Coordenação do Movimento Pré-Vestibular para Negros e Carentes, ex-aluna do PVNC e estudante de Comunicação.

108. Fábio Konder Comparato - Professor Titular do Departamento de Filosofia e Teoria Geral do Direito da USP.

109. Fátima Lobato Fernandes - Professora e Pesquisadora do Laboratório de Políticas Públicas da UERJ.

110. Fátima Oliveira - Médica. Secretária executiva da Rede Feminista de Saúde.

111. Federico Neiburg - Professor do Programa de Pós-Graduação em Antropologia Social do Museu Nacional - UFRJ.

112. Fernanda Kaingangue - Liderança Indígena Kaingangue. Mestra em Direito/ Diretora- Executiva do INBRAPI.

113. Fernanda Lopes - Bióloga, pesquisadora do Nepaids/USP e da área de Saúde e Sociedade/Cebrap.

114. Fernanda Peixoto - Professora de Antropologia da Universidade de São Paulo.

115. Fernando Pinheiro - Membro da Coordenação do Movimento Pré-Vestibular para Negros e Carentes, Professor da Rede Pública e pesquisador do NIREMAPUC/RJ.

116. Filipe Ceppas - Professor de Filosofia da Universidade Gama Filho e PUC-Rio.

117. Flávio Gomes - Professor da Universidade Federal do Rio de Janeiro.

118. Flávio Jorge Rodrigues da Silva - Diretor da Fundação Perseu Abramo 
119. Florentina da Silva Souza - Professora da Universidade Federal da Bahia (UFBA).

120. Francisca Novantino Ângelo Pareci - Mestra em Educação/ Representante Indígena do Conselho Nacional de Educação.

121. Francisco Carlos Cardoso da Silva Professor de Sociologia da UESB e doutorando em Antropologia pela PUC-SP.

122. Francisco Carlos Teixeira da Silva - Professor Titular da Universidade Federal do Rio de Janeiro.

123. Franck Pierre Ribard - Professor da Universidade Federal do Ceará.

124. Fransérgio Goulart - Fórum de Juventudes RJ.

125. Frédéric Monié- Professor do Departamento de Geografia da UFRJ.

126. Fulvia Rosemberg - Professora Titular da PUC-SP.

127. Geanne Campos - Socióloga, Coordenadora Executiva do Centro Aplicado de Pesquisa em Educação Multi-Étnica - CAPEM.

128. Geledés - Instituto da Mulher Negra.

129. Geo Britto - Sociólogo e ator e integrante do centro de Teatro do Oprimido.

130. Geraldo Bastos - Membro do Conselheiro Municipal dos Direitos dos Negros (COMDEDINE-Nova Iguaçu) e do GESTAR - Grupo de Estudos e Ação Racial.

131. Geraldo Magela Pereira Leão - Professor Adjunto da Faculdade de Educação da UFMG.

132. Geraldo Moreira Prado - professor do IBICT da Universidade Federal do Rio de Janeiro.

133. Geraldo Potiguar do Nascimento - Instituto Pedagógico para o Crescimento, Fortalecimento e Valorização da Cultura, do Viver Afro-Brasileiro e os Direitos Humanos - (sede) Porto Alegre - RS.

134. Gerardo Silva - pesquisador do Laboratório Territórios e Comunicações -

LABTeC/ESS/UFRJ.

135. Gevanilda Santos - Professora de História da África na Universidade da Cidade de São

Paulo/UNICID.

136. Giuseppe Cocco - Cientista Político e Professor da Escola de Serviço Social da UFRJ.

137. Gloria Rabay - professora do Curso de Comunicação Social da Universidade Federal da Paraíba (UFPB).

138. Greyce Kelly Fernandes de Almeida - Professora da rede municipal do RJ e diretora do SEPE (Sindicato Estadual dos Profissionais de Educação do RJ).

139. Guilherme José da Silva e Sá - Professor de Ciências Sociais da Universidade Federal de Santa Maria / Doutorando em Antropologia Social do Programa de PósGraduação em Antropologia Social do Museu Nacional - UFRJ.

140. Gustavo Henrique Araújo Forde - Membro do Centro de Estudos da Cultura Negra-ES e Mestrando em Educação da UFES.

141. Gustavo Proença - Advogado. Especialista em Direito Constitucional e em questões raciais.

142. Hamilton Pereira (Pedro Tierra) - Presidente da Fundação Perseu Abramo

143. Haroldo Costa - ator,escritor,membro do Conselho Estadual de Cultura do RJ

144. Hebe Mattos - Professora Titular de História do Brasil, Departamento de História, Universidade Federal Fluminense.

145. Helder Barbosa - Economista do SEBRAE-BA. 
146. Helen Campos Ferreira - Professora do Departamento Materno Infantil da Universidade Federal Fluminense.

147. Helena do Socorro Campos da Rocha - Representante do CONCEFET na implementação da Lei 10639 na Educação Profissional e Coordenadora do NEABCEFET- PA.

148. Helena Theodoro - Coordenadora do curso de Gestão doCarnaval, do Instituto do Carnaval da Universidade Estácio de Sá

149. Heliana de Barros Conde Rodrigues - Professora do Instituto de Psicologia da UERJ

150. Hélio Santos - Professor da Fundação Visconde de Cairu, de Salvador Presidente do Instituto da Diversidade, de São Paulo.

151. Henrique Cristóvão - Pesquisador do IPEAFRO.

152. Henrique Cunha Jr. - Professor Titular da Universidade Federal do Ceara.Livre docente pela USP. Membro fundador da Associação Brasileira de Pesquisadores Negros. Presidente do Instituto de Pesquisas da Afrodescendencia - IPAD. Membro da comissão

de estudos pro-cotas da Universidade Federal do Ceará.

153. Hercilene Costa - Professora de Filosofia da Educação da Universidade Estadual do Piaui - UESPI

154. Hernani Fracisco da Silva - Presidente da Sociedade Cultural Missões Quilombo, membro do MNE- Movimento Negro Evangélico.

155. Hilan Bensusan - Professor do Departamento de Filosofia da Universidade de Brasília (UNB).

156. Ilka Boaventura Leite - Professora de Antropologia da UFSC/Coordenadora do NUER.

157. Ilse Scherer-Waren - Professora de Sociologia da Universidade Federal de Santa Catatina. Membro da Comissão Acadêmica para formulação do Sistema de Cotas da UFSC.

158. Iolanda de Oliveira - Professora de Educação da Universidade Federal Fluminense (UFF)/Coordenadora do PENESB

159. Ione da Silva Jovino - Coordenadora do Programa São Paulo: Educando pela Diferença para a Igualdade, da Secretaria de Estado de Educação de São Paulo. Doutoranda em Educação pela Universidade Federal de São Carlos (UFSCar).

160. Iradji Roberto Eghrari - Gerente Executivo da Agere. Professor da UNIEURO.

161. Iraneide Soares da Silva Marinho - Kilombo - Organização Negra do Rio Grande do Norte.

162. Iris Maria da Costa Amâncio - Coordenadora do Curso de Pós-graduação em Estudos Africanos e Afro-brasileiros da PUC Minas e integrante do Núcleo de Inclusão Racial da PUC Minas)

163. Isabel Cristina Ferreira dos Reis - Professora Universitáriae doutoranda no Programade Pós-Graduação em História da Universidade Estadual de Campinas (Unicamp).

164. Isabel Cristina Martins Guillen - Professora Adjunta do Departamento de História da Universidade Federal de Pernambuco (UFPE).

165. Isabel Cruz - Professora Titular da Universidade Federal Fluminense (UFF), membro do Núcleo de Estudos sobre Saúde e Etnia Negra, Membro titular do Comitê Técnico de Saúde da População Negra do Ministério da Saúde.

166. Isabel Rosa Cabral - Professora da Universidade Federal Federal do Pará 
167. Itanacy Ramos de Oliviera (e demais companheiras) -Uila Mukaji - Sociedade das Mulheres Negras de PE.

168. Ivair Augusto dos Santos - Assessor da Secretaria Especial de Direitos Humanos do Ministério da Justiça.

169. Ivana Bentes -Professora e Diretora da Escola de Comunicação da UFRJ.

170. Ivanir Alves dos Santos - Coordenador do Centro de Articulação de Populações Marginais (CEAP), do Rio de Janeiro.

171. Izabel Cristina da Cruz - Professora de História e Subsecretária M. de Cultura de Itaboraí/RJ

172. Jacques d'Adesky - Pesquisador do Centro de Estudos das Américas do IH/UCAM.

173. Janô Beserra de Araujo - Professor de História e presidente do PT/ Itaboraí - RJ 174. Jeannete Alves - ECAIS/ SG - RJ

175. João Augusto Santos Silva - Coordenador do Bloco Afro Odomode - Porto Alegre

176. João Batista da Luz - Presidente da Irmandade Nossa Senhora do Rosário, Congado da Comunidade Negra dos Arturos, de Contagem, MG

177. João Batista da Silva - Geógrafo. Associação dos Geógrafos Brasileiros RJ.

178. João Bosco de Oliveira Borba - Presidente da Associação Nacional de Empresários e Empreendedores Afro-Brasileiros (ANCEABRA), com sede em Brasília

179. João Carlos Nogueira - Sociólogo e Ex-Subsecretario de Políticas de Ações Afirmativas da Secretaria Especial de Políticas de Promoção da Igualdade RacialPresidência da Republica.

180. Joao Costa Vargas - Professor da Universidade do Texas

181. João Diógenes Ferreira dos Santos - Professor de Sociologia da UESB e doutorando em

Ciências Sociais da PUC-SP.

182. João Jorge Rodrigues - Presidente do Bloco Afro Olodum

183. João José Reis - Professor Titular de História da Universidade Federal da Bahia (UFBA).

184. João Luiz Vieira - Professor da Universidade Federal Fluminense (UFF)

185. Joaze Bernardino Costa - Professor de Sociologia da Universidade Federal de Goiás

186. Jocelene Ignácio - Membro da Coordenação do Movimento Pré-Vestibular para Negros e Carentes (PVNC), Assistente Social e Professora Universitária.

187. Jocélio Teles dos Santos - Professor do Depto.de Antropologia e Diretor do Centro de Estudos Afro-Orientais(CEAO) da Universidade Federal da Bahia(UFBA)

188. Joel Zito Araújo - Cineasta

189. Joelma - Professora de História do Centro Universitário de Brasília (CEUB)

190. Jorge da Silva - Professor da Universidade do Estado do Rio de Janeiro (UERJ)

191. Jorge Luís Borges Ferreira - Geógrafo, pesquisador assistente do IPPUR/UFRJ, ex-presidente da Associação dos Geógrafos Brasileiros.

192. Jorge Luiz Mattar Villela - Professor de Antropologia da Universidade Federal de São Carlos

193. Jorge Luiz Silveira Ribeiro- Professor de Sociologia do Colégio Pedro IIUnidade Humaitá-RJ

194. Jorge Najjar - Professor da Faculdade de Educação da Universidade Federal Fluminense 
195. José Antonio Garcia Lima - Secretário de Finançasda CUT-RJ

196. Jose Antonio Moroni - Colegiado de Gestao do INESC - Diretor de relacoes institucionais da ABONG e membro do Conselho de Desenvolvimento Economico e Social (CDES)

197. José Carlos dos Anjos - Professor de Sociologia da Universidade Federal do Rio Grande do Sul (UFRGS) - Membro da Comissão Acadêmica Oficial para Formulação de um Sistema de Cotas na UFRGS

198. José Domingos Cantanhede Silva - Assessor da Federação dos Trabalhadores na Agricultura do Estado do Maranhão

199. José dos Santos Souza - Professor da Universidade Federal Rural do Rio de Janeiro (UFRRJ). Coordenador do Curso de Pedagogia do IM/UFRRJ.

200. José Geraldo Rocha - Professor da Universidade do Grande Rio (UnigranRio), da Universidade Estácio de Sá e da Pós-Graduação da Universidade Federal Fluminense (UFF)

201. Jose Jorge Siqueira - Professor da Pós-graduação em História da Universidade Severino Sombra.

202. José Junior - Coordenador Executivo do Grupo Cultural AfroReggae - RJ

203. José Luís Petrucelli - Pesquisador Titular do IBGE

204. José Reginaldo Santos Gonçalves - Professor da Universidade Federal do Rio de Janeiro (UFRJ)

205. José Roberto do Franco Reis - Pesquisador FIOCRUZ

206. José Sergio Leite Lopes - Professor do Programa de Pós-Graduação em Antropologia Social do Museu Nacional da UFRJ

207. Joselina da Silva - Professora substituta de Sociologia da UFRJ

208. Josildeth Gomes Consorte - Professora Titular de Antropologia da PUC-SP.

209. Juarez C. da Silva Jr. - Presidente do Movimento Afro-descendente do Amazonas

210. Juarez Dayrell - Professor Adjunto da Faculdade de Educação da UFMG Coordenador do Observatório da Juventude da UFMG e membro da equipe do Programa Ações Afirmativas na UFMG.

211. Juca Ribeiro - Secretário Executivo do Instituto Agenda e Coordenador do Projeto Agência.

212. Julio Cesar de Tavares - Professor de Antropologia e Comunicação da Universidade Federal Flumimense

213. Julio Vitor Costa da Silva - Aluno de ciências sociais da UFRJ e membro do núcleo universitário negro Luis Gama

214. Jurandir Freire Costa - Professor do Instituto de Medicina Social da Universidade do Estado do Rio de Janeiro.

215. Jurandyr Azevedo Araújo - Assessor da Pastoral Afro-brasileira da Conferencia Nacional dos Bispos do Brasil (CNBB).

216. Jurema Werneck - Médica. Coordenadora de Organização de Mulheres Negras CRIOLA.

217. Kabengele Munanga - Professor Titular de Antropologia da USP

218. Kênia Sousa Rios - Professora da Universidade Federal do Ceará

219. Lady Christina de Almeida - Membro da Coordenação do Movimento PréVestibular para Negros e Carentes (PVNC) e Pesquisadora do Núcleo Interdisciplinar de Reflexão e Memória Afrodescendente NIREMA/ PUC-Rio 220. Larissa Moreira Viana - Professora de História da Universidade Candido Mendes e da Universidade Federal do Rio de Janeiro. 
221. Laura Delgado Mendes - Professora da Universidade Federal Rural do Rio de Janeiro (UFRRJ)

222. Laura Lopez - Doutoranda em Antropologia Social (UFRGS) - Pesquisadora Associada ao Núcleo de Antropologia e Cidadania da UFRGRS

223. Leila Machado - Professora da Universidade Federal do Espírito Santo.

224. Leila Maria A.Barbosa - Professora de Historia. Presidente Instituto Cultural Baixo Santa do Alto Gloria

225. Leomar dos Santos Vazzoler- Associação de Mulheres Negras Oborindudu (Vitória- ES)

226. Leonor Franco de Araújo - Professora de História do Brasil e Africa da UFES. Coordenadora do NEAB/UFES. Membro do Movimento Negro Prócotas na UFES.

227. Leonora Corsini - psicóloga e pesquisadora do Laboratório Território e Comunicação da UFRJ

228. Lia Vieira - Associação de Pesquisas da Cultura Afro-brasileira ASPECAB/Niterói-RJ

229. Lídio de Souza - Professor do Programa de Pós-Graduação em Psicologia da Universidade Federal do Espírito Santo.

230. Lígia Dabul - Professora do Departamento de Sociologia da UFF

231. Liliana Porto - Professora de Antropologia da Universidade Federal do Paraná Coordenadora da Comissão de Acompanhamento do Programa de Cotas da UFPR

232. Liv Sovik - Professora da Escola de Comunicaçao - UFRJ

233. Lourenço Cardoso- escritor e ativista do movimento social negro. Formado em História na Pontifícia Universidade Católica de São Paulo (PUC-SP).

234. Lúcia Xavier - Coordenadora de CRIOLA e membro do Conselho Nacional da Igualdade

Racial (CNPIR)

235. Luciana Hartmann - Professora do Departamento de Artes Cênicas da UFSM

236. Luciana Vieira - diretora do sindicato dos bancários RJ

237. Lucilene Reginaldo - Professora de História da Universidade Estadual de Feira de Santana-UEFS

238. Lucimar Rosa Dias - Consultora do Centro de Estudos das Relações de Trabalho e Desigualdades (CEERT).

239. Luís Ferreira Makl - Professor Substituto de Antropologia da Universidade de Brasília/Pesquisador Associado do Núcleo de Estudos Afro-Brasileiros da UnB 240. Luís Reznik - Professor de História da PUC/RJ e da UERJ.

241. Luiz Alves Ferreira, Médico - Professor da Universidade Federal do Maranhão, Secretário Adjunto da Sociedade Brasileira para o Progresso da Ciência - SBPC/MA, Coordenador Geral do Centro de Cultura Negra do Maranhão- CCN-MA

242. Luiz AntonioCoelho - Professor da PUC/RJ.

243. Luiz Otávio Ferreira - Pesquisador da Fundação Oswaldo Cruz (FIOCRUZ)

244. Luiza Bairros - Projeto Raça e Democracia nas Americas - CRH/UFBA

245. Luiza Helena - Professora da PUC/RJ e Diretora do Departamento de Serviço Social.

246. Mara Felipe - Coordenadora da Escola Olodum

247. Marcelo Barbosa Santos - Historiador, MBA em Marketing Empresarial, direção do SINTFUB/Fasubra

248. Marcelo Cerqueira - Presidente do Grupo Gay da Bahia

249. Marcelo Paixão - Professor de Economia da Universidade Federal do Rio de Janeiro 
250. Marcelo Tragtenberg - Professor de Física da Universidade Federal de Santa Catarina (UFSC) - Membro da Comissão Acadêmica Oficial para Formulação de um Sistema de Cotas na UFSC

251. Marcia dos Passos Neves, professorada rede pública de ensino no Rio de Janeiro/ mestre em educação da UFF

252. Marcia Guerra - Professora de História da PUC-RJ.

253. Márcia Motta-Coordenadora do Programa de Pós Graduação em História da Universidade Federal Fluminense

254. Marcilene Garcia (Lena) de Souza - Diretora Executiva do Instituto de Pesquisa da Afrodescendência (IPAD).

255. Marcio Alexandre M. Gualberto - Editor de Afirma (Revista Negra Online).

256. Márcio Andre de Oliveira dos Santos - Mestre em Ciencias Sociaisl e Pesquisador do NIREMA da PUC/RJ.

257. Márcio Flávio - Membro da Coordenação do Movimento Pré-Vestibular para Negros e Carentes, geógrafo e integrante do NIREMA-PUC/RJ.

258. Marcio Goldman - Professor de Antropologia do Museu Nacional da UFRJ

259. Marco Antônio Domingues Teixeira - Professor de História da Universidade Federal de Rondônia (UNIR)

260. Marco Aurélio Máximo Prado - Professor da Universidade Federal de Minas Gerais

261. Marcus de Carvalho - Professor da Universidade Federal de Pernambuco

262. Marcus Eugênio O. Lima - Professor da Universidade Federal de Sergipe.

263. Maria Alice Rezende - Professora adjunta da Universidade do Estado do Rio de Janeiro.

264. Maria Aparecida Bento - Professora Doutora associada do Instituto de Psicologia da USP

265. Maria Aparecida Bergamaschi - Professora na Faculdade de Educação da Universidade Federal do Rio Grande do Sul (UFRGS) e Coordenadora do Programa Conexões de Saberes - UFRGS.

266. Maria Aparecida da Silva (Cidinha) - Pesquisadora do Instituto Kuanza, de São Paulo

267. Maria Aparecida Moura - Professora de Ciências da Informação da Universidade Federal de Minas Gerais

268. Maria Betânia Amoroso - Professora de Teoria Literária da Unicamp.

269. Maria Cláudia Cardoso Ferreira - Ex-aluna do PVNC, Historiadora, Professora da Rede Pública do Rio de Janeiro.

270. Maria Cristina Smith Menandro - Professora do Departamento de Psicologia Social e do Desenvolvimento - Universidade Federal do Espírito Santo

271. Maria da Conceição Carneiro Oliveira - historiadora e autora de livros didáticos. Prêmio Jabuti 2005.

272. Maria da Conceição Rosa Cabral - Professora da Universidade Federal do Pará 273. Maria da Glória Veiga Moura - Professora do Departamento de Artes Cênicas da Universidade de Brasília

274. Maria Elena Viana Souza - Professora da Universidade Federal do Estado do Rio de Janeiro - UNIRIO

275. Maria Gabriela Scotto - Professora do Instituto de Humanidades da Universidade Cândido Mendes 
276. Maria Helena Mendes Sampaio - Presidente da Entidade Sócio-Cultural Artístico- Religiosa Afro-Descendente Nagô-lorubá Afoxé Oyá Alaxé, lalorixá llê Oba Aganju - Recife.

277. Maria Isabel Pedrosa - Professora de Psicologia da Universidade Federal de Pernambuco - UFPE

278. Maria José Fontelas Rosado Nunes - Professora da PUC/São Paulo; pesquisadora do CNPq; membro da coordenação de Católicas pelo Direito de Decidir

279. Maria José Telles Franco Marques - Professora de Educação da Universidade Estadual de Mato Grosso do Sul (UEMS).

280. Maria Lúcia Carvalho da Silva - Professora Titular de Serviço Social da PUC$\mathrm{SP}$.

281. Maria Lúcia Felipe da Costa - Líder do Terreiro de Nação Nagô Senhora Santa Bárbara, de Água Fria, Recife

282. Maria Lúcia Martinello - Professora Doutora Associada do Serviço Social da PUC-SP.

283. Maria Lúcia Rodrigues Muller - Professora da Universidade Federal de Mato Grosso (UFMT) e Coordenadora do Núcleo de Estudos e Pesquisas sobre Relações Raciais e Educação (NEPRE) da UFMT

284. Maria Nazareth Soares Fonseca - Professora de Literaturas Africanas de Língua Portuguesa da PUC/MG. Organizadores dos livros Brasil afro-brasileiro (Editora Autêntica) e Poéticas afro-brasileiras (Editora PUC Minas/Mazza Edições).

285. Maria Nilza da Silva - Professora de História da Universidade Estadual de Londrina (UEL) - Coordenadora do Núcleo de Estudos Afro-Brasileiros da UEL

286. Maria Odete de Vasconcelos - Professora do Departamento de Histologia e Embriologia da Universidade Federal de Pernambuco (UFPE).

287. Maria Palmira da Silva - Doutora em Psicologia Social; Diretora da ABPN;Professorada Escola de Sociologia e Política de São Paulo.

288. Maria Regina Purri Arraes - Presidente da Comissão Permanente das Mulheres Advogadas- $\mathrm{OAB} / \mathrm{RJ}$

289. Marilda Checcucci Gonçalves da Silva - Professora de Antropologia da Universidade Regional de Blumenau.

290. Marilene Leal Pare - Pedagoga . Coordenação do Programa Nacional de Extensão "Conexões de Saberes" na FACED/PROREXT/UFRGS.

291. Marilu Campelo - Professora de Antropologia da Universidade Federal do Pará 292. Marilza Maia de Souza - Membro da coordenação do Movimento Pré-Vestibular para Negros e Carentes (PVNC). Bacharel em Letras/UERJ.

293. Mário Lisboa Theodoro - Professor de Políticas Sociais da Universidade de Brasília

294. Marisa Adriane Dulcini Demarzo - Pedagoga e pesquisadora do Neab/UFSCar

295. Mariza de Paula Assis - Professora da Universidade do Estado do Rio de Janeiro (UERJ).

296. Marlene Libardoni - Presidenta da ONG Ações em Gênero, Cidadania e Desenvolvimento (AGENDE), de Brasília

297. Marlise Matos - Professora Adjunta do Departamento de Ciência Política da UFMG

298. Marta Amoroso - Professora do Departamento de Antropologia da Universidade de São Paulo (USP) 
299. Marta Cezaria de Oliveira - Coordenadora do Forum Goiano de Mulheres e do Grupo de Mulheres Negras Dandara no Cerrado.

300. Marta Diniz Paulo de Assis - Professora de Psicologia da Educação da UFAM Universidade Federal do Amazonas e integrante do PENESB-UFF

301. Marta Rosa - Presidente da Fundação Municipal Zumbi dos Palmares-MG

302. Martha Abreu - Professora de História daUniversidade Federal Fluminense.

Pesquisadora1-d do CNPq.

303. Mary Garcia Castro - Professora UCSAL. Assessora da OEI-Organizaçao de Estados Iberoamericanos; membro da CNPD-Comissao Nacional de Populaçao e Desenvolvimento.

304. Maurício Santoro Rocha - Pesquisador do lbase e Professor da Universidade Candido Mendes

305. Mauro Cezar Coelho - Professor Doutor da Universidade Federal do Pará (UFPA)

306. Mauro William Barbosa de Almeida - Professor do Departamento de Antropologia da UNICAMP

307. Max Maranhão Piorsky Aires - Professor de Antropologia da Universidade Estadual do Ceará

308. Miguel González Arroyo - Professor Titular Emérito da Faculdade de Educação da Universidade Federal de Minas Gerais (UFMG)

309. Moacir Carlos da Silva - Integrante coletivo de estudantes negros e negras da UERJ (DENEGRIR)

310. Moacir Palmeira - Professor do Programa de Pós-Graduação em Antropologia Social do Museu Nacional - UFRJ

311. Moema de Poli - Pesquisadora do IBGE e Professora da Pós-Graduação do Programa de Educação sobre o Negro na Sociedade Brasileira da Universidade Federal Fluminense (PENESB/UFF)

312. Moisés Santana - Professor de Educação da Universidade Federal de Alagoas (UFAL) - Propositor do Sistema de Cotas da UFAL

313. Monica Lima - Professora do Colégio de Aplicação (CAP) da Universidade Federal do Rio de Janeiro

314. Muniz Sodré - Professor Titular de Comunicação da Universidade Federal do Rio de Janeiro

315. Naide Ribeiro Junior - Diretor do Sindicato dos Bancário do Rio de Janeiro

316. Nei Lopes - Bacharel em Direito e Ciências Sociais, Escritor e Compositor.

317. Nelson Inocêncio - Professor de Artes Visuais da UnB/Coordenador do NEAB da UnB

318. Neuza Poli - Coordenadora do Pré-Vestibular do Instituto Thema Educação, São Paulo, SP.

319. Nilma Lino Gomes - Professora de Educação da Universidade Federal de Minas Gerais (UFMG). Presidente da Associação Brasileira de Pesquisadores Negros (ABPN)

320. Nilo Rosa dos Santos - Professor da Universidade Estadual de Feira de Santanta.

321. Nivaldo pereira - Vice-Presidente do CDCN - ConselhoEstadual de Desenvolvimento da Comunidade Negra da Bahia. Conselheiro Associação Nacional de Advogados Afro- Descendentes/Bahia.

322. Oliveira Silveira - Poeta e Professor (RS)

323. Olívia Galvão - Professora da Universidade Estácio de Sá 
324. Olívia Maria Gomes da Cunha - Professora de Antropologia da Universidade Federal do Rio de Janeiro (UFRJ)

325. Ondina Pena Pereira - Professora de Filosofia da Universidade Católica de Brasília

326. Onir de Araujo -Advogado e coordenador do Movimento Negro Unificado (MNU) - RS

327. Osmundo Pinho - Professor do Departamento de Antropologia -UNICAMP

328. Otávio Velho - Professor Emérito da Universidade Federal do Rio de Janeiro (UFRJ) - Pesquisador 1-A do CNPq

329. Ovídio de Abreu Filho - Professor do Departamento de Antropologia da Universidade Federal Fluminense.

330. Pablo Gentili - Professor de Educação da Universidade do Estado do Rio de Janeiro (UERJ) - Diretor do LPP - UERJ

331. Patrícia Lânes - Pesquisadora do Ibase e integrante do Conselho Nacional de Juventude

332. Patrícia Sampaio - Professora da Universidade Federal do Amazonas

333. Paulino Cardoso - Coordenador do Núcleo de Estudos Afrobrasileiros (NEAB) da Universidade do Estado de Santa Catarina (UDESC).

334. Paulo Baía - Professor da Universidade Federal do Rio de Janeiro

335. Paulo Betti - Ator

336. Paulo Cesar Duque-Estrada - Professor da PUC-RJ

337. Paulo Cesar Rodrigues Carrano - Professor do Programa de Pós-Graduação em Educação da UFF.

338. Paulo Henrique Menezes - Liga Niteroiense De Capoeira / Niterói- RJ

339. Paulo Lins - Escritor

340. Paulo Santos -Engenheiro Cartógrafo do IBGE

341. Paulo Sérgio da Silva - Professor, historiador e membro do IACOREQ/RS

342. Paulo Staudt Moreira - Professor da Universidade do Vale dos Sinos/RS

343. Paulo Vinicius Baptista da Silva - Professor da Universidade Federal do Paraná e membro do Núcleo de Estudos Afro-Brasileiros NEAB-UFPR.

344. Pedro Simonard - Professor da SUESC

345. Petronilha Beatriz Gonçalves e Silva - Professora de Educação da Universidade Federal de São Carlos (UFSCAR) e conselheira do Conselho Nacional de Educação

346. Petrônio Domingues -Professor da Universidade Estadual do OestedoParaná (Unioeste)

347. Rachel Soihet - Professora do Programa de Pós-Graduação em História da Universidade Federal Fluminense (UFF)

348. Raimundo Jorge - Professor de Ciência Política da UFPA - Propositor do Sistema de Cotas da UFPA

349. Regina Domingues - Assessora Diretoria Executiva da Fase

350. Reginaldo Prandi - Professor Titular de Sociologia da USP.

351. Renato Athias - Professor do Programa de Pós Graduação em Antropologia da Universidade Federal de Pernambuco e Coordenador do Núcleo de Estudos e Pesquisas sobre Etnicidade (NEPE-UFPE).

352. Renato Emerson dos Santos - Professor de Geografia da Universidade do Estado do Rio de Janeiro (UERJ)

353. Renato Ferreira - Advogado da EDUCAFRO - Pesquisador do PPCOR-UERJ

354. Renato Nogueira Jr - Doutor em Filosofia (UFRJ) e Professor da FAETEC. 
355. Ricardo Chaves - Professor de Pediatria da Universidade do Estado do Rio de Janeiro

356. Ricardo de Oliveira - Professor da Universidade Federal Rural do Rio de Janeiro

357. Ricardo Salles - Professor da Universidade do Estado do Rio de Janeiro e da UNIRIO

358. Rilkim Tavares Rodrigues - Presidente da UCAB (União dos Cultos Afro do Brasil)

359. Rita de Cássia Tavares Medeiros - Professora da Faculdade de Educação Da Universidade Federal de Pelotas-RS

360. Rita Laura Segato - Professora de Antropologia da Universidade de Brasília Pesquisadora 1-A do CNPq - Propositora do Sistema de Cotas da UnB

361. Robert Slenes - Professor de História da Universidade Estadual de Campinas, UNICAMP

362. Roberto Gonçalves da Silva - Professor de Urbanismo da Universidade Federal de Santa Catarina

363. Roberto Martins - Ex-Diretor do IPEA, Professor Aposentado de História Econômica da Universidade Federal de Minas Gerais

364. Robson Campos Leite - Professor de Cultura e Cidadania do PVNC e Coordenador do Movimento de Fé, Política e Cidadania do Rio de Janeiro.

365. Rodrigo Ednilson de Jesus - Coordenador Executivo do Programa Conexões de Saberes na UFMG e Professor do Centro Universitário UNA

366. Rodrigo Guéron - Professor da Universidade Cândido Mendes, Cineasta e Doutor em Filosofia pela UERJ.

367. Rogeria Peixinho - Coordenadora Estadual da Articulação de Mulheres Brasileiras - Rio de Janeiro

368. Romário Schettino - Presidente do Sindicato de Jornalistas do Distrito Federal

369. Ronaldo Barros - Professor de Filosofia da Universidade Estadual da Bahia

370. Ronilda lyakemi Ribeiro - Professora Doutora do Instituto de Psicologia da USP

371. Roque Peixoto - Movimento do Hip Hop Organizado Brasileiro (MHHOB), Membro da

Coordenação Nacional do Encontro Nacional de Juventude Negra (ENJUNE)

372. Roquinaldo Ferreira - Professor da Universidade de Vírginia - EUA

373. Rosana Heringer - Coordenadora Geral de Programas da ActionAid Brasil.

374. Rosângela 'Janja' Costa Araújo - Coordenadora do Programa de Educação do Geledés- Instituto da Mulher Negra. Doutora em Educação/USP.

375. Rosilene Alvim - Professora do Programa de Pós-Graduação de Sociologia e Antropologia do Instituto de Filosofia e Ciências Sociais da UFRJ

376. Ruben Caixeta de Queiroz - Professor de Antropologia da Universidade Federal de Minas Gerais.

377. Sales Augusto dos Santos - Doutorando de Sociologia da UnB. Pesquisador do NEAB da UnB

378. Sebastião Arcanjo - Tiãozinho- Deputado Estadual PT/SP - Coordenadorda Frente Parlamentar em Defesa da Igualdade Racial na Assembléia Legislativa de SP.

379. Selma Pantoja - Professora da Pós-graduação em História da Universidade de Brasília

380. Sergei Suarez Dillon Soares - Pesquisador do IPEA

381. Sergio Baptista da Silva - Professor de Antropologia da UFRGS 
382. Sergio Mauricio Pinto - Professor de Filosofia e Antropologia da Unime e da FEBA, em Salvador, BA

383. Sérgio Rizek - Editor da Attar Editorial, São Paulo.

384. Sidney Chalhoub, - Professor Titular de História do Brasil da UNICAMP

385. Silvia Hunold Lara - Professora de História na Universidade Estadual de Campinas (UNICAMP)

386. Sílvio Humberto Cunha - Professor de Economia da Universidade Estadual de Feira de Santana (UEFS)/Diretor do Instituto Steve Biko.

387. Simone Born de Oliveira - Advogada e Professora da UNISUL/UNIVALI (SC)

388. Sonia Weidner Maluf - Professora de Antropologia da Universidade Federal de Santa Caratina

389. Suelaine Carneiro - Geledés Instituto da Mulher Negra

390. Sueli Carneiro - Doutora em Educação pela USP, Diretora do Geledés Instituto da mulher Negra

391. Suely Gomes Costa - Professora do Mestrado em Política Social e do Programa de Pós-Graduação em História da UFF.

392. Sydenham Lourenço Neto - Historiador e Cientista Político, Professor da UERJ.

393. Sylvia Caiuby Novaes - Professora de Antropologia da Universidade de São Paulo

394. Tânia Almeida - Professora da UERJ

395. Tânia Mara Campos de Almeida - Professora da Pós-Graduação em Psicologia da Universidade Católica de Brasília.

396. Tânia Stolze Lima - Professora de Antropologia da Universidade Federal Fluminense

397. Tatiana Roque - Professora do Instituto de Matemática da UFRJ.

398. Teresinha Bernardo - Professora Titular de Antropologia da PUC-SP.

399. Thiago Thobias - Assessor de Políticas Públicas e Ações Afirmativas da Sede da Educafro.

400. Uelinton Farias Alves - Jornalista e escritor

401. Urivani de Carvalho - Diretora de Arte da Revista Eparrei.

402. Valter Roberto Silvério - Professor de Sociologia da Universidade Federal de São Carlos (UFSCAR)/Membro da Comissão Oficial para Formulação de um Sistema de Cotas para a UFSCAR

403. Vanda da Cruz Santos - Instituto Cultural Steve Biko- Bahia

404. Vânia Beatriz Monteiro da Silva - Professora de Educação da Universidade Federal de Santa Catarina

405. Vanusa Maria de Melo - Produtora Cultural. Coordenadora do grupo de Cultura Popular pé-de-chinelo.

406. Vera Cristina de Souza - Professora Doutora da UNISA e pesquisadora da Universidade Zumbi dos Palmares

407. Vera Lúcia Neri da Silva - Coordenadora do Instituto Baobab - Educação, Gênero e culturas Negras.

408. Vera Rodrigues - Mestra em Antropologia. Integrante do GT de Ações Afirmativas da UFRGS

409. Verena Alberti - Pesquisadora do CPDOC-FGV

410. Vilma Áreas - Professora Titular de Teoria Literária da Unicamp.

411. Vincent Carelli - Documentarista e Coordenador de Vídeo nas Aldeias.

412. Volnei Garrafa - Professor titular e coordenador da Cátedra UNESCO de Bioética da Universidade de Brasília; editor da Revista Brasileira de Bioética. 
413. Walace Nascimento - Representante do Fórum de Entidades Negras.

414. Walter Altino de Souza Junior - Movimento Negro Atitude Quilombola. Mestre em sociologia pela UFBA.

415. Walter Fraga Filho - Professorda Universidade do Estado da Bahia(UNEB)

416. Wanessa Paula Conceição Quirino dos Santos - Presidente do Maracatu Nação Cambinda Estrela(Recife-PE)

417. Williman Hestefany da Silva - Presidente do Conselho Estadual de Participação e Integração da Comunidade Negra - CCN/MG.

418. Wilma de Nazaré B. Coelho - Professora da Universidade Federal do Pará e da Universidade da Amazônia.

419. Wilson Roberto de Mattos - Pró-Reitor de Pesquisa e Ensino de PósGraduação da UNEB. Conselheiro do Conselho Nacional de Educação.

420. Zeidi Araujo Trindade - Professora do Programa de Pós-Graduação em Psicologia da Universidade Federal do Espírito Santo.

421. Zélia Amador de Deus - Professora de Artes da UFPA - Propositora do Sistema de Cotas da UFPA.

\section{APOIO:}

1. Abigail Alcantara Silva - Economista

2. Adelaide Maria Afonso Máximo Barbosa - Professora

3. Adriana Medeiros - Fotógrafa

4. Adriani Faria - Coordenadora do ECAU (Estudantes e Comunidade Afro da UNISINOS)

5. Albineiar Plaza Pinto - Médica integrante do Grupo Feminista Autônomo Oficina Mulher - Goiânia - Goiás

6. Alessandra Tosta - Mestra em Antropologia Social pelo Museu Nacional/UFRJ.

7. Alexandra Barbosa da Silva - Doutoranda em Antropologia Social do Museu Nacional-UFRJ.

8. Alva Helena de Almeida - Enfermeira

9. Alvaro Maciel - Diretor Cultural da Amaleme/Assoc. Moradores do Leme/Rio de Janeiro

10. Amilcar Araujo Pereira - Doutorando em História da Universidade Federal Fluminense

(UFF)

11. Ana Carneiro Cerqueira - Doutoranda em Antropologia Social do Museu Nacional/UFRJ

12. Ana Carneiro Cerqueira - doutoranda em antropologia social no Museu Nacional/UFRJ

13. Ana Cristina de Mello Pimentel Lourenço - Socióloga, Professora e Mestranda em Direito e Sociologia na UFF

14. Ana Maria Bonjour - Historiadora e Produtora Cultural.

15. André Barros - Advogado

16. Anita Fiszon - Artista Visual

17. ARTEIROS (grupo de teatro de rua, Recife - PE)

18. Associação Casa da Mulher Catarina - grupo feminista autônomo, Florianópolis, SC.

19. Athayde Motta - Doutorando em Antropologia pela Universidade do Texas em Austin.

20. Barbara da Silva Rosa - Psicóloga 
21. Beatriz Alves dos Santos - cidadã

22. Bianca Brandão - Antropóloga e Documentarista

23. Bruno Ribeiro Marques - Mestrando em Antropologia Social do Museu Nacional/UFRJ

24. Camila Pinheiro Medeiros (doutoranda em Antropologia Social do Museu

Nacional/UFRJ).

25. Carla Susana Alem Abrantes - Mestranda de Antropologia Social / UFRJ

26. Carlos Henrique Romão de Siqueira - Doutorando pelo Centro de Pesquisa para Améria Latina e o Caribe - da Universidade de Brasília.

27. Cassi Ladi Reis Coutinho - Graduanda de História da Universidade Católica do Salvado

28. Cecília Campello do Amaral Mello - Doutoranda em Antropologia Social do Museu

Nacional-UFRJ

29. CEDENPA - Centro de Estudos e Defesa do Negro do Pará

30. CENEG - Coletivo Estadual de Estudantes Negros - RJ

31. CENUNBA - Coletivo do s Estudantes Negros das Universidades da Bahia - BA

32. CFEMEA - Centro Feminista de Estudos e Assessoria

33. Claudia Mura - Mestranda de Antropologia Social / UFRJ

34. Claudio Thomas -Engenheiro da Computação

35. Cristina Lopes - Bacharel em Ciências Sociais pela UFRJ e pesquisadora do Ibase

36. Daniel Augusto Fernandes - Psicólogo - Belo Horizonte/MG

37. Denise de Oliveira Carneiro - Assistente Social -SP

38. Dinéia dos Santos Barbosa - Secretária

39. Dulce Mungoi - Doutoranda em Antropologia Social na Universidade Federal do Rio Grande do Sul (UFRGS)

40. Ecio Pereira de Salles - Doutorando em Comunicação e Cultura - ECO/UFRJ.

41. Efigênia Maria Nolasco Duarte - Auditora Fiscal da Receita Federal

42. Eliane Costa Santos - Pesquisadora em Educação Matemática. Técnica de Formação de Educadores do CEAFRO. Ebomi do Terreiro do Cobre.

43. Elizabeth do Espírito Santo Viana - Mestranda em História Comparada IFCS/UFRJ

44. Ernesto Ignacio de Carvalho - Mestrando em Antropologia pela Universidade Federal de Pernambuco

45. Fábia Barbosa Ribeiro - Doutoranda em História Social pela USP.

46. Fabio Mura - Doutorando em Antropologia Social do Museu Nacional/UFRJ.

47. Fabricia Corrêa - Geógrafa e professora do municipio de São Pedro da Aldeia

48. Fátima Machado Chaves - Doutora em saúde pública. Professora de História da rede pública e Professora Universitária.

49. Flávia Ferreira Pires - Doutoranda em Antropologia SocialMuseu Nacional/UFRJ

50. Flávio Eduardo N. Teixeira - Engenheiro Eletricista.

51. Francelino José da Silva Neto - SOS Racismo da Assembleia Legislativa de São Paulo

52. Frederico Lisbôa Romão - Cientista Social

53. Frei Antonio Leandro da Silva - mestrando em Ciências Sociais

54. Geraldo Lafayette - Secretário de Cultura, Lazer e Turismo de Conselheiro Lafaiete, MG.

55. Gerson Carlos Rezende - Mestre em Educação. 
56. Gilberto Batista Campos - historiador e Militante do Movimento Negro - VitoriaES

57. Giovana Xavier da Conceição Côrtes - Doutoranda em História na UNICAMP.

58. GRUPO DE TRABALHO DE AÇÕES AFIRMATIVAS UM PROJETO DE EXTENSÃO DA UFRGS

59. Gustavo Amora - Assessor em Advocacy da Agere Cooperação em Advocacy e mestrando do Instituto de Ciências Políticas da UnB.

60. IFHA-RHADHÁ DE ARTE NEGRA (grupo de teatro de rua, Olinda - PE)

61. Isabel Aparecida dos Santos - Coordenadora de programas de educação em Direitos Humanos do IBEAC.

62. Ísis Aparecida Conceição - Mestranda Faculdade de Direito da USP

63. Ivaldo Marciano de França Lima - Mestre do Maracatu Nação Cambinda Estrela (Recife- PE), Mestre em História (UFPE) e Doutorando em História (UFF).

64. Ivo de Santana - Doutorando em Ciências Sociais da Universidade Federal da Bahia

(UFBA).

65. Ivo Rodrigues - Secretário-Geral do Maracatu Nação Cambinda Estrela (RecifePE), Licenciado em História (FUNESO)

66. Jacira Vieira de Melo - filósofa, jornalista e diretora do Instituto Patrícia Galvão

67. Jaime Amparo Alves - Mestrando em Antropologia Social da University of Texas at Austin (USA)

68. Jesiel Ferreira de Oliveira Filho - Professor de literatura e doutorando em Letras pela Universidade Federal da Bahia.

69. João Roberto Lopes Pinto - Coordenador do Instituto Brasileiro de Análises Sociais e Econômicas - Ibase

70. Joel Carlos Rodrigues Otaviano - Graduando da Escola Nacional de Ciências Estatísticas.

71. Joel Ronaldo Sudário - Bacharel em Serviço Social e Membro do Movimento Negro

Capixaba

72. Jonathan L. Hannay - Secretário Geral da Associação de Apoio à Criança em Risco - ACER

73. Jose Antônio de Souza Gomes - Graduando de Ciências Sociaisda UFES.

74. Jose Carlos Madureira Siqueira - Professor da rede publica estadual do Rio de Janeiro.

75. José Lino de Oliveira - Professor

76. José Renato de Carvalho Baptista - Doutorando em Antropologia Social Museu Nacional/UFRJ

77. Josué Hennemann Vergara de Souza - Estudante.

78. Julia Frajtag Sauma - Mestrando de Antropologia Social do PPGAS UFRJ/Museu Nacional

79. Juliana Barros, advogada da Associação de Advogados de Trabalhadores Rurais da Bahia

80. Júnia Sales Pereira - Doutora em Historia UFMG

81. Jussara Nascimento de Oliveira Pereira - Membro da equipe de Orientação Vocacional do PVNC. Graduanda em Psicologia pela PUC-Rio.

82. Karin Veloso Mazorca - Advogada.

83. Laura Lopez - Doutoranda em Antropologia Social (UFRGS) - Pesquisadora Associada ao Núcleo de Antropologia e Cidadania da UFRGRS 
84. Lavínia Coutinho Cardoso - Historiadora, Mestranda em História Social das Relações Políticas na Universidade Federal do Espírito Santo (UFES). Bolsista de mestrado do Projeto Conexões de Saberes- SECAD\MEC\ UFES.

85. Leonardo Fortes Gomes - Professor

86. Liliam Aquino Meireles dos Santos- Coordenadora de Gênero do Grupo Atitude Quilombola e Mestranda em Estudos Étnicos e Africanos- UFBA.

87. Lourdes Carril - Geógrafa.

88. Lucia Regina Silva - Enfermeira

89. Luciana Garcia de Mello - Socióloga e Doutoranda em Sociologia da Universidade Federal do Rio Grande do Sul (UFRGS);

90. Luciana Soares da Silva - Professora e Mestranda em Língua Portuguesa -PUC$\mathrm{SP}$

91. Luciano José Pacheco da Silva - Funcionário público. Graduando de Administração da Universidade Estadual do Rio Grande do Sul (UERGS).

92. Luisete da Costa Portela - Servidora Pública FederalAposentada e Professora

93. Luiz Kohara - Centro Gaspar Garcia de Direitos Humanos

94. Magna Almeida de Souza - Professora

95. Mani Maria Pereira - Jornalista da Revista Educando de Porto Alegre/RS

96. MARACATU NAÇÃO CAMBINDA ESTRELA (Recife -PE)

97. Marcia Aparecida Cruz - Costureira.

98. Marco Antonio dos Santos - Jornalista e Membro do Conselho de Participação e Desenvolvimento da Comunidade Negra do estado de São Paulo

99. Margarida Barreto - Médica.Doutora em Psicologia Social/PUC/SP.

100. Maria Adelina Guglioti Braglia - Coordenadora do programa RAíZES, Governo do Estado do Pará

101. Maria Ana de Oliveira Diolindo - Secretária

102. Maria de Fátima Tardin Costa - Arquiteta e Urbanista, Mestre em Direito da Cidade pela UERJ

103. Maria do Carmo Barbosa Galdino - Professora da rede pública de Belo Horizonte

104. Maria do Carmo Gregorio- Professora da Rede Municipal de Belford Roxo

105. Maria Elvira Díaz Benítez - Doutoranda em Antropologia Social do Museu Nacional da UFRJ.

106. Maria José Campos - Doutoranda em Antropologia Social - USP

107. Mariana Selister Gomes - estudante de História da UFRGS

108. Marina Sidrim Teixeira -Socióloga

109. Marisa Yoshie Sanematsu - jornalista e webeditora do Instituto Patrícia Galvão

110. Mateus Gonçalves - Licenciado em Artes Cênicas- UFRGS

111. Michelle Cristine Milheiro de Souza - estudante de Letras

112. Míriam Virgínia Ramos Rosa - Doutoranda em Antropologia pela Universidade de Brasília

113. Natalino Nevesda Silva - Coordenador do Núcleo de Arte e Cultura - NAC, Belo Horizonte, Minas Gerais

114. Nelma Gomes Monteiro. Professora, Militante do movimento negro e Doutoranda em Educação pela UFES.

115. Nelza Jaqueline Siqueira Franco - Professora da rede municipal de Porto Alegre/RS. Beneficiada pela política de cotas adotadas por esse município quando do ingresso na rede municipal de ensino.

116. Oswaldo de Aquino Pereira Junior - Engenheiro e Professor do PVNC - Anil 
117. Patrícia Reinheimer - Doutoranda em Antropologia Social do Museu Nacional/UFRJ.

118. Pedrina de Deus - Publicitária

119. Pedro Gerolimich - Direção Estadual Partido dos Trabalhadores - PT/RJ e estudante de Geografia UERJ

120. Pedro Henrique de Andrade- Bacharelando em Ciencias Sociais- Uel

121. Rafael Gutierrez Giraldo - Doutorando em Literatura Brasileira da PUC/RJ

122. Raymundo Rodrigues - Arquiteto

123. REDE MULHERES NEGRAS - PR

124. REDE UNIVERSIDADE NÔMADE (www.universidadenomade.org.br)

125. Regina Parente - Mestre emEducação pela UFRGS/RS

126. Reinaldo da Silva Guimarães - Sociólogo

127. Reinaldo da Silva Soares - Doutor em Antropologia Social pela Universidade de

São Paulo e sociólogo da Prefeitura da Cidade de São Paulo.

128. Ricardo Oliveira de Freitas- Doutor em Comunicação e Cultura

129. Rita de Cássia dos Santos Camisolão - Licenciada em Letras - RS

130. Roberto Júnior de Oliveira - Teólogo da Igreja Metodista, Bacharel em Direito e Mestrando em Educação na UNESP.

131. Rodrigo Rosistolato. Ex-aluno, atual professor do PVNC-Petrópolis. Doutorando em antropologia pelo PPGSA/IFCS/UFRJ

132. Ronaldo Gonçalves dos Santos / Doutorando em Eng. Química (UNICAMP)

133. Rosimeire Barboza da Silva - Mestranda em Sociologia pela Universidade de Coimbra.

134. Ruth Floresta de Mesquita - Enfermeira da Secretaria Municipal de Saúde do Rio de Janeiro.

135. Sara Rodrigues da Silva - Vice-Presidenta da Escola de Samba Gigante do Samba, de Recife

136. Segisvaldo Luiz Caldo- Professor da rede estadual de São Paulo.

137. Silene Gonçalves da Silva - Assessora Parlamentar do Deputado Federal César Medeiros-MG

138. Sílvia Maria Prado da Silva - Psicóloga

139. Silvyane Luanda Prata - estudante de Serviço Social

140. Sonia Silva Paiva Mota Gonçalves- Enfermeira.

141. Soraia da Rosa Mendes - Advogada, especialista em direitos humanos e mestre em Ciência Política pela UFRGS.

142. Tadeu Valadares - Embaixador do Brasil em Bucareste

143. Thiago Mendonça - cineasta

144. INSTITUTO DE ASSESSORIA AS COMUNIDADES REMANESCENTES DE QUILOMBOS DO RIO GRANDE DO SUL (IACOREQ).

145. Tomas Martin Ossowicki - Doutorando em Antropologia Social - Museu Nacional - UFRJ

146. Valéria C. A. Álvares - Estudante universitária da UFBA.

147. Vanderli Salatiel - Educadora, membro do Grupo Cultural Dandara

148. Vanessa Mantovani Bedani - Professora da Rede Estadual/Membro do Núcleo de Estudos Afro-Brasileiro da Universidade Federal de São Carlos

149. Vera Regina Ferreira Fontes - Advogada e militante dos Direitos Humanos

150. Vicente Cândido - Deputado Estadual/SP

151. Viviane Becker Narvaes - Mestranda em Teatro da Universidade Federal do Estado do Rio de Janeiro - UNIRIO 
152. Zeca Esteves - Militante do Movimento Negro e Filiado ao PT.

153. Gláucia Matos Adeniké, pedagoga, educadora popular, feminista, membro da MMMMMundial de Mulherese Forum Nacional de Mulheres Negras. 